Universidade de São Paulo

Faculdade de Filosofia Letras e Ciências Humanas

Departamento de Linguística

THIAGO MOREIRA CORREA

INSCRIÇÕES URBANAS: ABORDAGEM SEMIÓTICA VERSÃO CORRIGIDA 
THIAGO MOREIRA CORREA

thiago.moreira.correa@usp.br

\title{
Inscrições urbanas: abordagem semiótica
}

\author{
versão corrigida
}

Tese apresentada ao Programa de Pósgraduação em Semiótica e Linguística Geral da Faculdade de Filosofia, Letras e Ciências Humanas da Universidade de São Paulo para a obtenção do título de Doutor em Letras.

Área de concentração: Semiótica.

Orientador: Prof. Dr. Antônio Vicente S. Pietroforte.

De acordo:

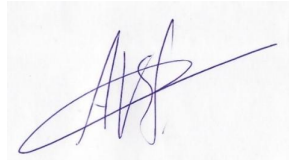

Prof. Dr. Antônio Vicente S. Pietroforte 
Autorizo a reprodução e divulgaçào total ou parcial deste trabalho, por qualquer meio convencional ou eletrônico, para fins de estudo e pesquisa, desde que citada a fonte. Moreira Correa : orientador Antonio Vicente Seraphim Pietroforte. - São Paulo, 2016.

$213 \mathrm{f}$.

Tese (Doutorado) - Faculdade de Filosofia, Letras - Ciências Humanas da Universidade de Săo Paulo. Departamento de Linguistica. frea de concentraçào: Semibtica e Linguistica Geral.

1. Semiótica. 2. Linguistica. 3. Historia da Arte. 4. Graffiti. 5. Cultura Underground. 1. Pietroforte, Antonio Vicente Seraphim, orient. II. Titulo. 
Nome: CORREA, Thiago Moreira.

Título: Inscrições urbanas: abordagem semiótica.

Tese apresentada ao Programa de Pós-graduação em Semiótica e Linguística Geral da Faculdade de Filosofia, Letras e Ciências Humanas da Universidade de São Paulo para a obtenção do título de Doutor em Letras.

Área de concentração: Semiótica.

Aprovada em: / 2016

BANCA EXAMINADORA

Prof. Dr.

Julgamento:

Prof. Dr.

Julgamento:

Prof. Dr.

Julgamento:

Prof. Dr.

Julgamento:

Prof. Dr.

Julgamento:
Instituição:

Assinatura:

Instituição:

Assinatura:

Instituição:

Assinatura:

Instituição:

Assinatura:

Instituição:

Assinatura: 
à Juliana Maian 


\section{AGRADECIMENTOS}

À minha família, de nascimento e de casamento, em especial, à minha mãe e ao meu pai, que sempre me deram todo suporte na vida.

À Juliana Maian, pela paciência, pela compreensão e pelo incentivo incondicional.

À Maria Giulia Dondero e ao Antônio Vicente S. Pietroforte, pela orientação libertadora.

À Mariana Luz Pessoa de Barros, pela arguição na banca de qualificação.

Aos colegas de trabalho do Ges-Usp, em especial, à Elizabeth Harkot-de-La-Taille, por sua generosidade acadêmica e pela arguição na banca de qualificação.

Aos amigos "vicentinos", Carolina Tomasi, Débora C. Ferreira de Camargo, Cleyton Fernandes e Ricardo Akira Sanoki, pela camaradagem.

À Carolina Lindenberg Lemos pelas conversas semióticas e não-semióticas.

À Ilca Suzana Lopes Vilela pela leitura atenta e pela amizade atenciosa.

À Natália Cipolaro Guirado pela revisão e pelas parcerias, ao Edson Gomes Jr. pelas traduções para o inglês e pela revisão do resumo e à Juliana Pondian pela revisão das traduções e pelas conversas belgas e brasileiras.

$\mathrm{Na}$ Espanha, aos professores Ana Navarrete Tudela, Vicente Jarque e Javier Díez de Baldeón García pelo acolhimento e pelo estímulo às reflexões sobre Arte.

À Beatriz Vilariño Cerdá e à sua família pelo apoio e companheirismo.

Na Bélgica, aos professores Sémir Badir e François Provenzano pela recepção e pelos debates, e ao Enzo D'Armenio pela valiosa amizade e pelas discussões no Carré.

Ao Departamento de Linguística da Universidade de São Paulo, em especial, à Secretaria e à Coordenação, que sempre impulsionaram minha pesquisa.

Ao CNPq, pela bolsa de doutorado no país e à CAPES, pela bolsa do PDSE. 



\section{RESUMO}

CORREA, T. M. Inscrições urbanas: abordagem semiótica. 2016. 209 f. Tese (Doutorado) - Faculdade de Filosofia, Letras e Ciências Humanas, Universidade de São Paulo, São Paulo, 2016.

A diversidade das abordagens em relação às inscrições urbanas reflete a sua complexidade. Cada análise, seja ela sociológica, psicológica, histórica ou artística, constrói o objeto segundo seu ponto de vista (SAUSSURE, 1997), o que limita a investigação da prática. Se considerarmos as inscrições urbanas como uma confluência de movimentos, social e artístico, a articulação desses dois fatores é preponderante, visto que é a ausência dessa relação que tem determinado abordagens enviesadas de sua manifestação. Então, a partir dessas segmentações unilaterais, nossa tese propõe uma ampliação nas tendências de análise, ao considerar a história das inscrições urbanas sob o viés da prática, do texto e do objeto. Dessa forma, busca-se apontar as conservações e as inovações das estruturas de formação do sentido das inscrições urbanas em função de suas mudanças históricas. No nível da prática, um modelo de dinâmica social, baseado nas teorias de Merton (1970) Coseriu (1979) e Klinkenberg (2008, 2010), é estabelecido para explicar a produção dos enunciados, cujas relações entre o plano do conteúdo e o plano da expressão (FIORIN, 2008) e a influência da repetição na formação de algumas modalidades (LEMOS, 2015) desenvolvem nossa abordagem nesse nível de análise. Já o nível do objeto faz a junção com a prática e o texto por meio do suporte, que encontra na proposta de Dondero (2016) e Fontanille (2005, 2015) uma forma pertinente de tratamento de nosso objeto. Ressaltamos que, embora o tratamento histórico tenha uma base interdisciplinar, devido às necessidades do objeto, o processo de produção do sentido na diacronia é nosso objetivo principal e para isso, as teorias da linguagem conduzem todo o desenvolvimento de nossa reflexão, na qual a semiótica tensiva (ZILBERBERG, 2012) possui um especial destaque em razão de suas contribuições a respeito das dinâmicas processuais do sentido. Assim, acreditamos que a complexidade das inscrições urbanas exige novos tipos de abordagem, permitindo à teoria semiótica se desenvolver na apreensão de práticas cujo sentido é formado em uma forte dependência entre os níveis de análise do texto.

Palavras-chave: Semiótica; Linguística; História da Arte; Graffiti; Cultura Underground. 


\begin{abstract}
CORREA, T. M. Urban inscriptions: a semiotic approach. 2016. $209 \mathrm{f}$. Thesis (Doctorate) - Faculdade de Filosofia, Letras e Ciências Humanas, Universidade de São Paulo, São Paulo, 2016.

The diversity of approaches related to urban inscriptions reflects its complexity. Each analysis, whether it is sociological, psychological, historical or artistic, builds the object through its own point of view (SAUSSURE, 1997), which limits research. Considering urban inscriptions as the merger of social and artistic movements, the articulation of these two assets is preponderant, hence it is the absence of this relation that has been determining biased approaches of this manifestation. Therefore, from this unilateral segmentation, our thesis suggests an extension in trends of analysis, when considering the history of urban inscriptions under the viewpoint of practice, text and object. That way, we intend to point out maintenance and innovations of meaning generation structures applied to urban inscriptions according to their historical changes. Considering practice, a social dynamics model based on the theories of Merton (1970), Coseriu (1979) and Klinkenberg $(2008,2010)$, is established to explain the production of enunciates, which relations between the expression and content fields (FIORIN, 2008) and the influence of repetition on the composition of some modalities (LEMOS, 2015) develop our approach in this analysis approach. The object sphere takes part in a link with practice and text through the support, which meets in the proposal of Dondero (2016) and Fontanille $(2005,2015)$ a pertinent way to deal with our object. We highlight that, although historical approach has an interdisciplinary basis due to the object's needs, the process of meaning generation in the diachrony is our main goal and, for that reason, the theories of language conduct all our reflection development, in which Tensive Semiotics (ZILBERBERG, 2012) plays a special role due to its contributions to the procedural dynamics of meaning. Thus, we believe that the complexity of urban inscriptions demands new approaches that allows development of the Semiotic Theory in the learning of practices which meaning is generated in a strong dependency among the levels of text analysis.
\end{abstract}

Keywords: Semiotics; Linguistics; Art History; Graffiti; Underground Culture. 


\section{LISTA DE FIGURAS}

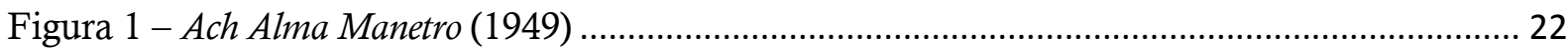

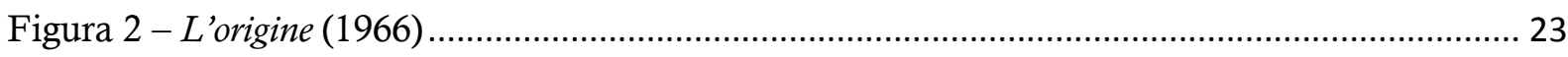

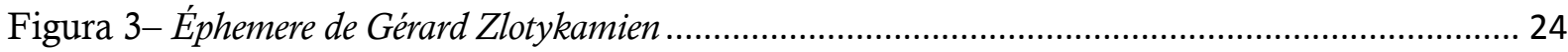

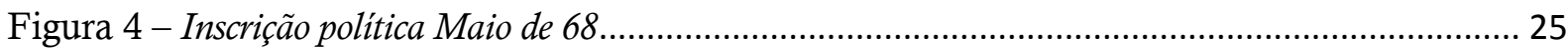

Figura 5 - Tags no metrô de N.Y. ........................................................................................... 26

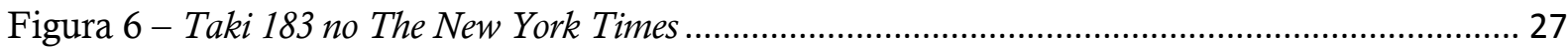

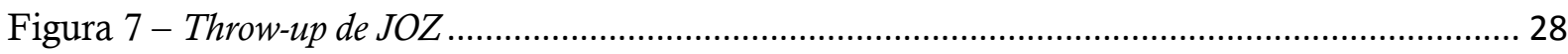

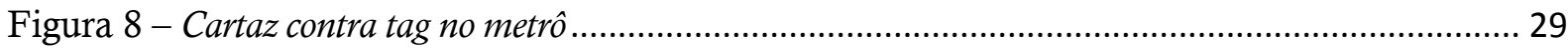

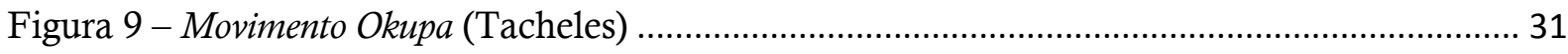

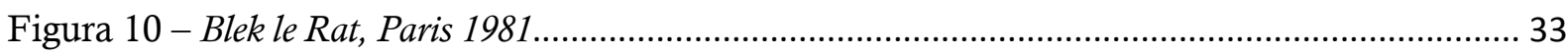

Figura 11 - "Le hasard bave des formules de magie noire" de Miss. Tic.................................................... 34

Figura 12 - "An eye for an eye makes the whole world blind" de Jef Aerosol .......................................... 34

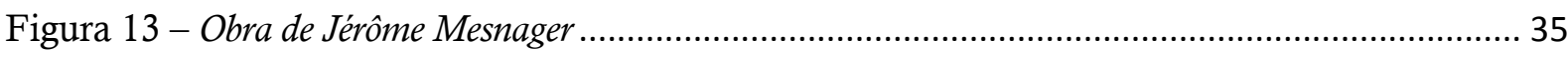

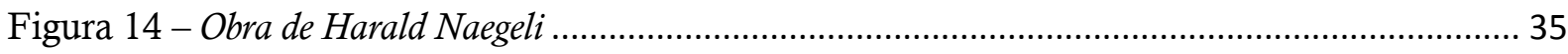

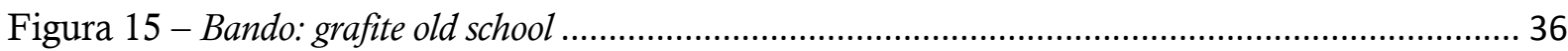

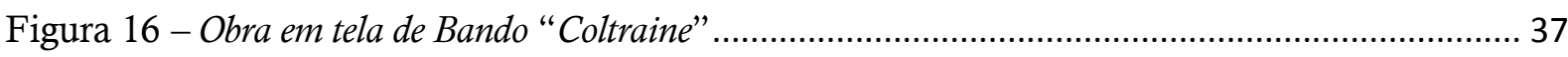

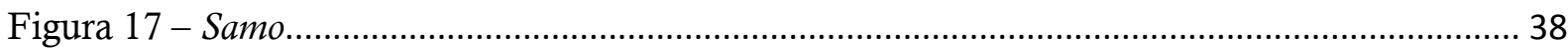

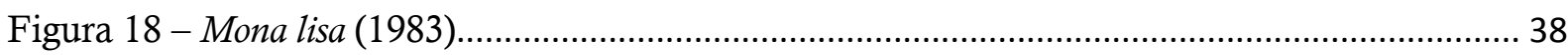

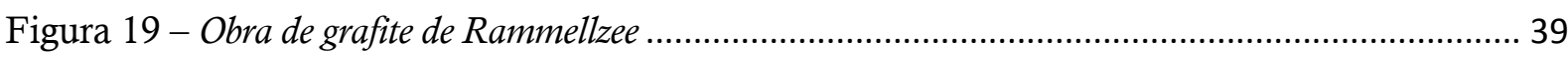

Figura 20 - Atomic Note Maestro Atmosferic de Rammellzee ................................................................ 39

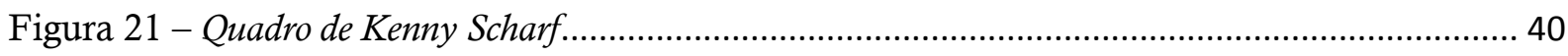

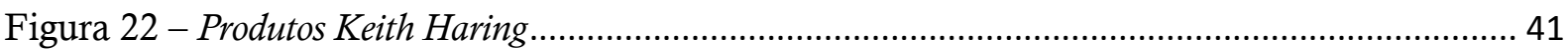

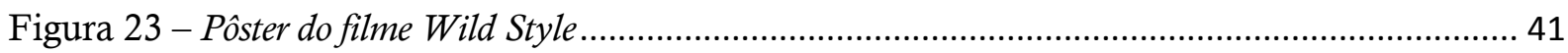

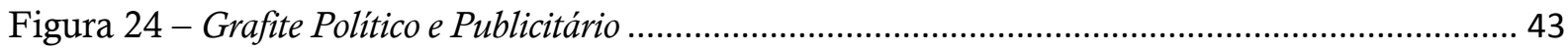

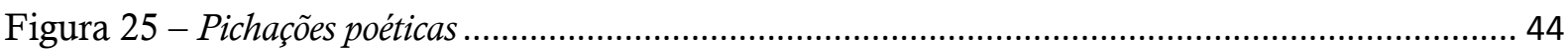

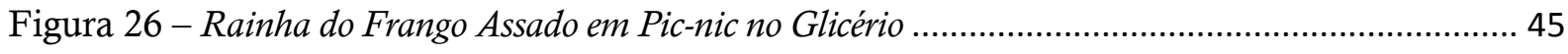

Figura 27 - Mural de Ruy Amaral no túnel da Avenida Paulista ........................................................ 46

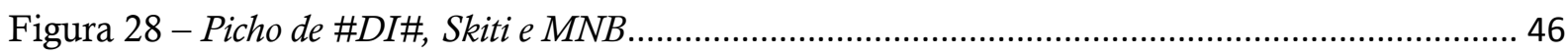

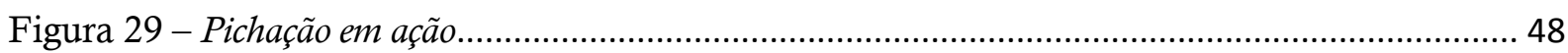

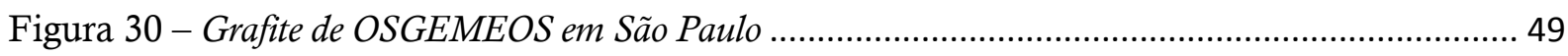

Figura 31 - Inscrição urbana de Nunca.......................................................................................... 50

Figura 32 - Inscrição urbana de Cranio na Passagem Literária da Consolação ...................................... 51

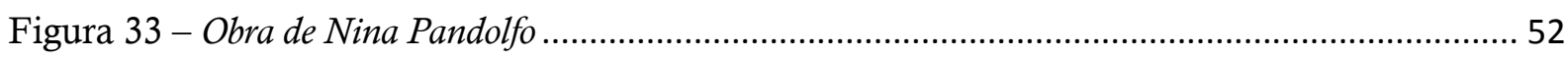

Figura 34 - Banksy em releitura da obra Des glaneuses de Jean François Millet .................................... 54

Figura 35 - Cartaz da Campanha de Barack Obama e Obey de Shepard Fairey .................................... 55

Figura 36 - Invaders (Rua Peixoto Gomide, São Paulo).............................................................. 55

Figura 37 - Kobra retrata Tom Zé (bairro Vila Madalena em São Paulo)........................................ 56

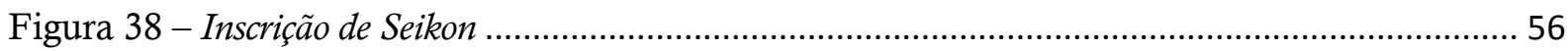

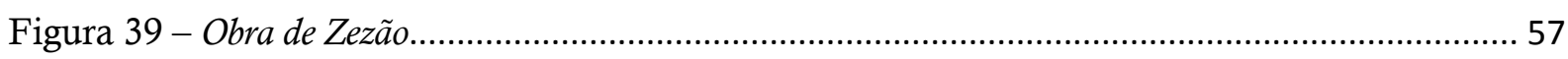

Figura 40 - The Caves obra de Edgar Mueller ……….................................................................... 57

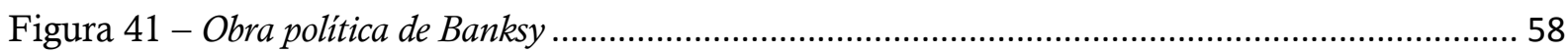

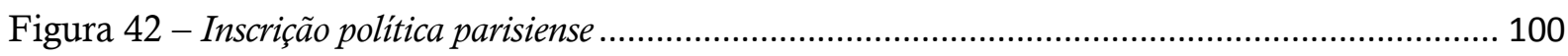




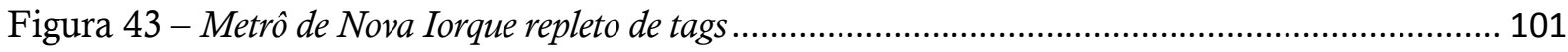

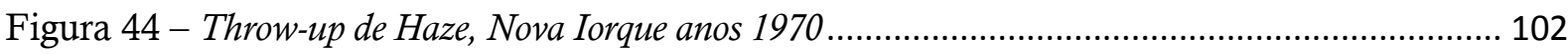

Figura 45 - Grafite United Artists............................................................................................ 104

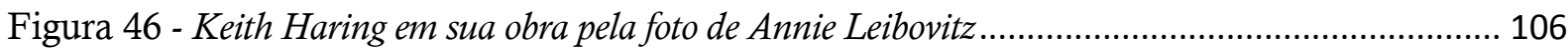

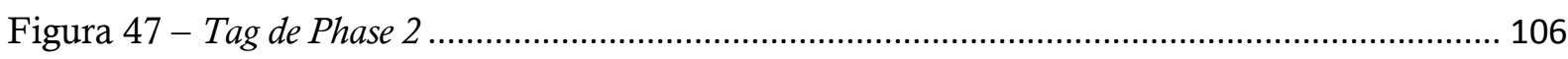

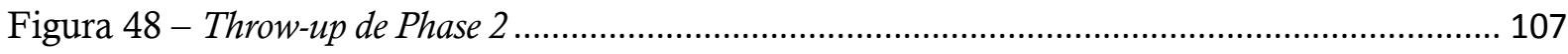

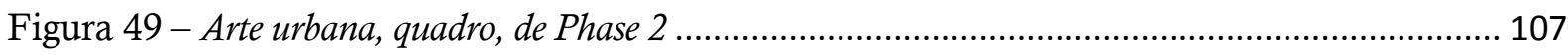

Figura 50 - Pichação Lixomania ............................................................................................. 109

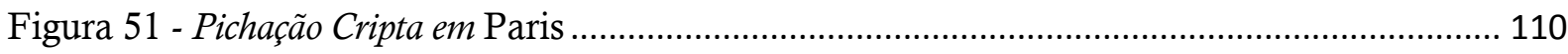

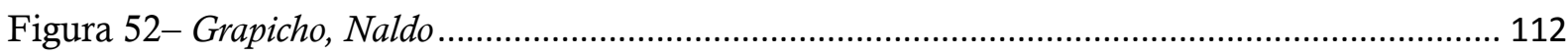

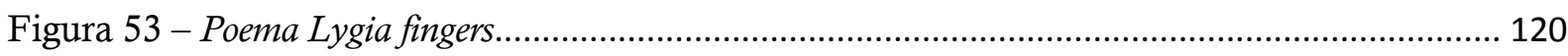

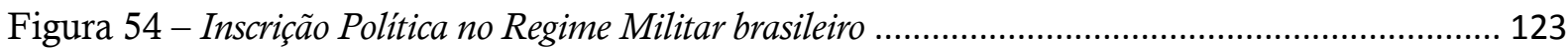

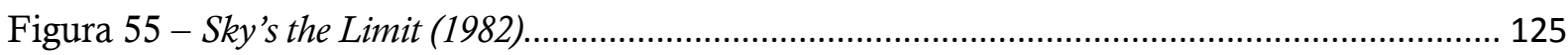

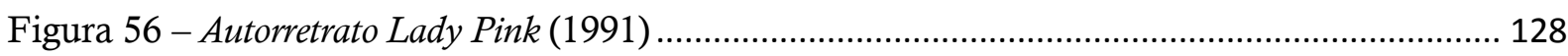

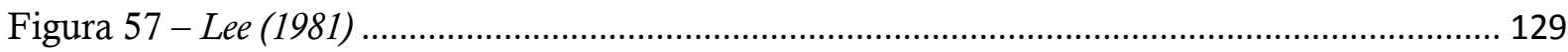

Figura 58 - Peaceful Hearts Doctor (São Francisco, EUA)............................................................. 147

Figura 59 - Inscrição anônima feita no periodo dos jogos olimpicos de Londres .................................... 148

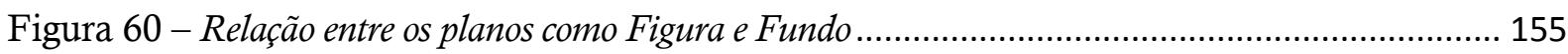

Figura 61 - Expressão e conteúdo no símbolo .............................................................................. 156

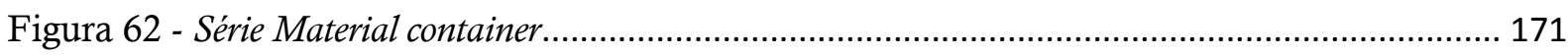

Figura 63 - Comparação entre suportes na obra de Crash .................................................................... 178

Figura 64 - Grafite de Samo (Jean-Michel Basquiat)................................................................... 179

Figura 65 - Tela de Basquiat .................................................................................................... 179

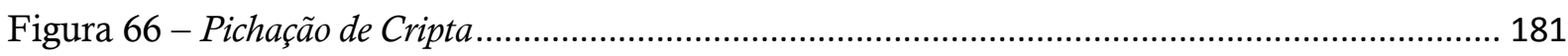

Figura 67 - Pichação-arte de Cripta em galeria nova-iorquina ......................................................... 181

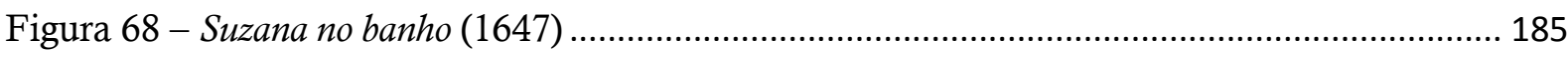

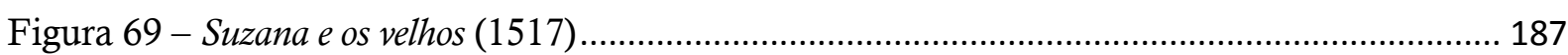




\section{SUMÁRIO}

1.1 ORIGENS NO SÉCULO XX 21

1.2 BREVE HISTÓRIA DAS INSCRIÇÕES URBANAS: (R) EVOLUÇÕES 30

1.3 BREVE HISTÓRIA DAS INSCRIÇÕES URBANAS NO BRASIL _

1.4 MULTIPLICIDADE DA ARTE URBANA

2.1 DISCUSSÃO SOBRE AS NORMAS 67

2.2 VALOR 70

2.3 VALORES NAS INSCRIÇÕES URBANAS 72

2.4 NORMAS PARA AS INSCRIÇÕES URBANAS

2.5 MODELO NORMATIVO

2.5.1 INOVAÇ̃̃O E RITUALIZAÇÃO__ 90

2.5.2 RITUALIZAÇÃO__ 94

2.5.3 CONFORMIDADE 97

2.6 MODALIDADES 99

2.6.1 INSCRIÇÕES POLÍTICAS _ 100

2.6.2 TAGE THROW-UP__ 101

2.6.3 GRAFITE — 104

2.6.4 ARTE URBANA 105

2.6.5 PICHAÇÃO__ 108

2.6.6 GRAPICHO__ 111

$\underline{3} \underline{\text { RELACCÃO ENTRE OS PLANOS NAS INSCRIÇÕES }} 114$

3.1 O ÚTIL E O ESTÉTICO NAS INSCRIÇÕES URBANAS 121

3.2 SISTEMA SIMBÓLICO E INSCRIÇÕES URBANAS. _ 133

3.2.1 PICHAÇÃO__ 143

3.3 SÍMBOLO DENTRO DAS INSCRIÇÕES _ 146

3.3.1 SALIÊNCIA DOS PLANOS _ 149

3.3.2 FIGURA E FUNDO NO PROCESSO SIMBÓLICO _ـ 160

$\underline{4}$ SUPORTE 165

4.1 MUDANÇAS DE SUPORTE NA HISTÓRIA DAS INSCRIÇÕES URBANAS. 175

4.2 BASES IMPLICATIVAS E CONCESSIVAS 183

4.3 LÓGICA IMPLICATIVA E CONCESSIVA NA ESCOLHA DE SUPORTE 


\section{INTRODUÇÃO}

É necessário um melhor conhecimento das regras gerais de transformações estruturais, antes de se poder pronunciar com alguma certeza sobre o caráter específico das transformações diacrônicas.

Greimas 
Há muito tempo o homem imprime suas marcas em paredes. No início, seus ancestrais marcavam rochas e cavernas com linhas e cores que formavam homens, animais, plantas e paisagens; ao longo da história, vieram os hieróglifos, as inscrições romanas, os afrescos renascentistas e as inscrições muralistas. Enfim, a parede é um suporte antigo no qual o homem se expressa. No entanto, na década de 1960, surgiu um movimento mais intenso nas metrópoles mundiais: palavras de liberdade apareceram impressas nos muros de Paris, enquanto sprays espalhavam assinaturas por toda Nova Iorque (STAHL, 2009). As inscrições urbanas tomavam os muros do mundo.

Das cavernas aos muros, a humanidade expressa-se por meio de inscrições em superfícies coletivas. No entanto é preciso separar essas expressões realizadas em épocas tão distintas, porque afora o fato de possuírem suportes semelhantes e partirem do mesmo ato, essas inscrições, cada uma em sua época, carregam sentidos diferentes. É como colocar objetos ritualísticos de tribos africanas na categoria de escultura e associá-los às obras de Brâncusi, sem respeitar às especificidades de cada prática.

Dessa forma, a Street Art (ou o Grafite ou a Arte Urbana) é delimitada ao século XX, o que já rompe com algumas linhas de pesquisa de cronologia mais expansiva, e ao pensar nos diversos tipos de inscrições feitas no espaço urbano, geralmente denominadas de grafite, buscou-se um termo neutro que englobasse todas essas modalidades ${ }^{1}$, pois o termo grafite acumula a função de modalidade específica e de termo genérico. Por isso, o termo inscrição urbana resolveria essas dualidades que interferem na clareza da análise.

Mesmo com uma denominação mais generalizante, as inscrições urbanas ainda abarcam diversas modalidades que se mesclam, muitas vezes, a estilos artísticos já consolidados, o que deixa para o analista uma difícil tarefa de selecionar sua

\footnotetext{
${ }^{1}$ Conforme apontado na banca de defesa da tese, a palavra escolhida em seu sentido lato cria um ruído terminológico, ao ser abordada em um discurso vinculado à Semiótica. $\mathrm{O}$ "cada um dos aspectos ou feições diversas de um todo" (BORBA, 2004, p. 929) produz uma inconsistente simplificação. Entretanto, a reflexão produzida em torno do termo mais adequado ampliou nossas perspectivas e trouxe também alguns questionamentos, que necessitam de uma investigação além-tese. A divisão da totalidade das inscrições urbanas em partes autônomas pode, talvez, ser desenvolvida na teoria bakhtiniana dos gêneros discursivos, cuja ideia de "formas discursivas reconhecidas de uma coletividade que em diferentes ocorrências apresentam uma certa semelhança"(FLORES, 2009, p. 132) traz uma perspectiva pertinente à prática social das inscrições urbanas. Apesar disso, o uso provisório do termo modalidade foi mantido.
} 
relevância em relação à prática em si. Porém as fronteiras fluidas entre estilos não é novidade na investigação sobre arte - embora haja certa identidade que permita sua categorização. Desse modo, busca-se delimitar algumas modalidades de inscrições urbanas e compreender sua formação.

Então, são escolhidas algumas modalidades porque a abrangência desse movimento artístico é vasta. Esculturas, cartazes, adesivos, performances, vídeos, etc., fazem parte dessa extensa categoria chamada inscrição urbana, que carece, em sua delimitação, do mesmo rigor formal aplicado pela história da arte à sua própria tradição. Como escapa à nossa tarefa fazer esse tipo de seleção formal dentro da história da arte, partimos de estilos já consolidados pela crítica para desenvolver nossa pesquisa.

As modalidades elencadas ligam-se ao gênero artístico majoritariamente da pintura, que, em uma acepção genérica, "consiste na aplicação de pigmentos coloridos num plano bidimensional no qual os suportes (superfície sobre a qual se pinta) podem ser dos mais variados, como telas, murais, paredes, papéis, metais, cerâmicas ou o próprio corpo" (BUENO, 2013, p. 73).

Essa definição prática conduziria às escolhas das modalidades, mas tendo em conta outras propostas: como a construção perceptiva da pintura (ALBERTI, 1999, p. 82), que vai tratar os objetos percebidos por meio de um esquema triangular, cuja base seria a superfície, os lados (em relação a essa base) seriam os raios de luz que circundam a superfície (raios extrínsecos) e o vértice da pirâmide (como chama Alberti) seria o olho do espectador. Logo, a pintura não seria outra coisa "que a intersecção da pirâmide visual representada com arte por linhas e cores numa dada superfície, de acordo com certa distância e posição do centro e o estabelecimento de luzes" (ALBERTI, 1999, p. 88). Conta-se também com as reflexões de Schwartzmann (2014) sobre a escolha enunciativa do tipo de substância que levaria a um efeito de pintura, pois "se o enunciador escolhe o colorido ou escolhe o desenho, ele está pressupondo que o enunciatário receberá de forma diferente cada uma das técnicas escolhidas". Dessa maneira, "o nanquim, o guache e o betume dão efeito de sentido de pintura, já que são fluidos e absorvidos pelas cerdas de um pincel que espalha suas partículas pelo papel".

Esse efeito de pintura concorre de certa forma com um efeito de desenho e, no caso da pichação, essa separação torna-se menos nítida, pois do mesmo modo que "o 
grafite, giz pastel e carvão são materiais que nos dão um efeito de sentido de desenho", a tinta spray aplicada sobre as superfícies da cidade traria efeitos semelhantes, já que "riscam a superfície rugosa" do muro (SCHWARTZMANN, 2014, p. 94).

Pode-se dizer, então, que a escolha das modalidades é preponderantemente vinculada à pintura, mas é válido ressaltar que as inscrições urbanas ainda são pouco exploradas nas teorias da arte em relação à sua técnica, o que traz instabilidade para inserir as inscrições urbanas nos gêneros artísticos, cujas problematizações já são muitas no campo da arte.

Além disso, a escolha das modalidades está ligada ainda mais à sua importância na história das inscrições urbanas, pois, segundo nossa proposta, é a partir de algumas modalidades estruturantes que a prática se desenvolve e se expande ao longo do tempo. Paris e Nova Iorque seriam os centros originadores das variações de inscrições urbanas. Por meio de triagens e misturas de normas, o enunciador seguiria rumo ao seu valor de reconhecimento, criando uma dinâmica de produção ora pela conservação de estilos, ora por sua inovação. Assim, a perspectiva histórica aponta para uma categorização formal, ou seja, observa-se um conjunto de obras, cujo gênero pintura seria predominante, pela análise diacrônica da prática.

Em favor dessa preponderância histórica, o primeiro capítulo traz uma síntese da história das inscrições urbanas, com base em linhas de pesquisa que marcam a origem dessa prática no século XX. A tripartição, Brasil, Estados Unidos e França, mostraria a formação, a consolidação e a expansão da prática no mundo. Contudo é preciso ressaltar que a cronologia realizada respeita a critérios estruturais, abordados ao longo da tese. Além disso, o primeiro capítulo tem a função de "preparar o terreno" para a análise, que depende de um conhecimento prévio sobre as inscrições urbanas.

Após essa preparação histórica, o texto exigirá um conhecimento prévio sobre a teoria semiótica francesa. Menos por pedantismo que por incapacidade didática, segue-se por esse estilo de escrita. A concisão e a objetividade conduziram o texto a uma frieza acadêmica e, claro, a uma confirmação da previsível especificidade desse gênero textual.

Então, os capítulos seguintes vão abordar as inscrições urbanas em diferentes níveis de análise. No segundo capítulo, a prática é investigada em seu caráter social, 
pois se definem as estruturas formadoras de cada tipo de modalidade e sua repercussão no texto plástico. Um modelo é proposto para explicar a dinâmica social da prática, cujo impacto no nível textual é determinante.

O terceiro capítulo trata do nível textual, em que a relação entre plano da expressão e plano do conteúdo vai pautar nossa reflexão, já que a divisão da origem histórica vai sugerir que as inscrições urbanas parisienses dariam maior relevância ao plano do conteúdo e as inscrições nova-iorquinas salientariam o plano da expressão. Essa hipótese será analisada pelo viés dos conceitos de função utilitária e função estética da linguagem (FIORIN, 2008), além dos conceitos de símbolo e semissimbolismo aplicados aos textos de inscrição urbana.

Pela proposta de Dondero (2016), chega-se ao quarto capítulo que vai "ligar as pontas". De acordo com o modelo de Fontanille (2015), o nível da prática e o nível do texto são intermediados pelo nível do objeto, cujo desenvolvimento proposto por Dondero (2016) se concentra no suporte. Assim, observa-se a dupla articulação do suporte, voltado para a prática, pelo suporte material, e voltado para o texto, pelo suporte formal, que vai contribuir para as escolhas enunciativas formadoras do texto.

A investigação acerca dos fatores que contribuem para a produção do sentido das inscrições urbanas, sejam eles no nível textual, no nível do objeto ou da prática, passam pela instância da enunciação, "que assegura a colocação em enunciadodiscurso as virtualidades da língua" (GREIMAS e COURTÉS, 2008, p. 166). Essa atualização das virtualidades linguageiras feitas pelo enunciador marca, na tese, a relação entre normas e valores, a repetição formadora de determinadas modalidades e a escolha do suporte, quer dizer, é na cena enunciativa que as inscrições urbanas teriam um lugar privilegiado de análise e é pelas marcas deixadas no enunciado que se encontram os modelos propostos em cada nível. Ainda que não se realize um percurso direto, do enunciado para a enunciação, nossa investigação busca sua validade no enunciado. Assim:

A enunciação é concebida como um componente autônomo da teoria da linguagem, como uma instância que possibilita a passagem entre a competência e a performance (linguísticas); entre as estruturas semióticas virtuais, de cuja atualização ela deve encarregar-se, e as estruturas realizadas sob forma de discurso (GREIMAS e COURTÉS, 2008, p. 166). 
Permeadas pelas escolhas enunciativas, na diacronia, as inscrições urbanas demandam uma abordagem expansiva em cada nível de análise. Os patamares da significação, que se acumulam e se sustentam para manifestar-se, estão concentrados no enunciado e tentar estabelecer um processo inverso de desdobramento torna-se nosso objetivo.

Devido à complexidade oferecida pelo corpus, nossa pesquisa tomou os modelos teóricos existentes, bem como os modelos criados, a partir do objeto de análise. Desse modo, criou-se uma espécie de teoria do objeto. Não se estabelece uma reflexão epistemológica, nem uma aplicação de modelos, mas, sim, uma adaptação teórica provinda das inscrições urbanas.

Cada modalidade está constituída em função de sua prática e de seu objeto. Por isso, o texto faz mais sentido em relação a um sistema maior que o estrutura, dependendo do ponto de vista, chamado de texto ou prática.

Assim, acreditamos que o caminho percorrido para explicar esse fluxo de sentido, que perpassa vários níveis de análise, pode e deve ser questionado, desde que seja considerada a existência dessa dinâmica complexa do objeto e que seja impulsionada a necessidade de sua reflexão. A tese mostra uma possibilidade de abordagem da história das inscrições urbanas, cujos modelos apresentados buscam sistematizar a produção de sentido dessa prática contemporânea, mais como um fim em si mesmo que como um meio para outras finalidades. 


\section{BREVE HISTÓRIA DAS INSCRIÇÕES URBANAS: ESCOLHA DAS ORIGENS}

Imagine uma cidade em que o grafite não é ilegal, uma cidade em que qualquer um pode desenhar onde quiser. Onde cada rua seja inundada de milhões de cores e frases curtas. Onde esperar no ponto de ônibus não seja uma coisa chata. Uma cidade que pareça uma festa para a qual todos foram convidados, não apenas as autoridades e os figurões dos grandes empreendimentos. Imagine uma cidade como essa e não encoste na parede - a tinta está fresca.

Banksy 
Propõe-se ilustrar o desenvolvimento das inscrições urbanas de acordo com a produção artística atual. Como as mudanças no mundo da arte costumam ter uma evolução lenta (DONDERO, 2014, p. 2), não é possível prever se os artistas escolhidos para explicar o fenômeno contemporâneo terão aval histórico posteriormente. Contudo pretende-se que o modelo teórico, além de aprofundar o conhecimento sobre as obras, crie as bases para a compreensão da futura continuação ou exclusão dos paradigmas artísticos considerados.

Assim, as inscrições urbanas serão abordadas inicialmente na relação do movimento internacional para o nacional, pois conforme passam as décadas, maior e mais rápida é a circulação de informação no mundo e torna-se menor a separação regional. Ao chegar aos anos 2000, já não é mais necessária essa distinção, porque o diálogo entre os artistas e a divulgação de suas obras passa a ser simultâneo na maior parte da comunidade internacional. Para compreender essa transformação, é preciso conhecer sua história e sua evolução formal.

A primeira escolha a ser feita, então, reside na delimitação histórica do movimento, pois assim é possível compreendê-lo dentro de um campo coerente de relações. Entre as diversas propostas sobre o tema, duas perspectivas principais marcam a origem das inscrições urbanas, uma definida a partir da pintura rupestre na pré-história e outra a partir dos grafites no século XX.

As inscrições urbanas podem ser consideradas como uma forma contemporânea de uma prática humana histórica ou um fenômeno característico da contemporaneidade. Ambas as perspectivas conduzem a caminhos de análise distintos. Ao aceitar as inscrições urbanas como herdeiras da pintura rupestre, torna-se necessário desenvolver uma linha histórica que abranja toda essa tradição "muralista", cujo campo de investigação se concentraria na história da arte. Entretanto o estabelecimento de uma relação pertinente entre a pré-história e a contemporaneidade parece improvável sob o viés das inscrições urbanas, haja vista que é apenas neste último período, comparado aos seus precedentes, que haverá uma maior intensidade e homogeneidade produtiva.

Além disso, o spray, o pincel atômico, as mídias exteriores, a cultura de massas e a metrópole, que são fatores específicos do século XX, possuem maior pertinência para a formação das inscrições urbanas que uma possível herança pré-histórica. 
Portanto, o argumento desenvolvido será em torno da ideia de que as inscrições urbanas têm sua origem a partir dos anos de 1960.

\subsection{ORIGENS NO SÉCULO XX}

Principal instrumento de trabalho dos inscritores ${ }^{2}$, o spray, originado em 1790 sob a forma de um sistema de aerossol, na França, chegou ao modelo atual em 1949, com uma válvula apta a esguichar qualquer líquido. No mesmo ano, Edward Seymour criou a primeira lata de tinta spray da cor alumínio, o que deu início a sua comercialização (BELLIS, 2012). Já o pincel atômico, usado exclusivamente em tags, teve sua primeira patente registrada por Lee Newman em 1910 nos Estados Unidos, cujo modelo se desenvolveu ao longo dos anos até chegar à patente de Walter J. De Groft em 1944, quem propiciou seu uso comercial em 1964 pela caneta Sharpie e seus produtos decorrentes, como o pincel atômico (permanent marker). Por serem leves e portáteis, o spray e o pincel favoreceram o estabelecimento das inscrições urbanas. Cada instrumento tinha sua função. As latas empregadas pelos sprayers permitiam o uso de diversas cores e a rápida execução de suas obras. $\mathrm{O}$ pincel atômico tinha o formato ideal para realizar as assinaturas (tags) em qualquer lugar ${ }^{3}$. Devido à ilegalidade, a rapidez da produção era essencial para evitar o flagrante da polícia.

Outro elemento fundamental foi a influência das mídias exteriores, que utilizavam seus suportes de forma eficaz na comunicação de massas. Muro, parede e vagão de trem eram os meios encontrados pelos inscritores para alcançar maior visibilidade, enquanto a cultura de massas, especialmente a publicidade, fornecia referências iconográficas e estratégias de comunicação com o público a jovens ávidos pela fama. Pelos meios de comunicação audiovisuais ou impressos, a cultura de massas criava um discurso próprio com o qual as inscrições urbanas dialogaram.

\footnotetext{
${ }^{2}$ Termo empregado para designar os produtores de inscrição urbana, em uma adaptação livre do inglês writers (escritores), que designa os grafiteiros em Nova Iorque.

${ }^{3}$ A tag é feita tanto por pincel atômico quanto por spray, enquanto que todas as outras modalidades de inscrição urbana são realizadas com spray e tinta. O uso do pincel atômico é considerado pelos inscritores como uma prática amadora e em muitos países sua venda é proibida.
} 
A conjunção desses fatores ocorria na metrópole. Ela propiciava o anonimato do criador, em oposição à exposição pública da obra. Via-se a obra, mas não o autor. Em razão desse apagamento subjetivo propiciado pelas multidões, pelas constantes inovações tecnológicas levadas ao mercado consumidor, pela separação urbanística das cidades em centro-periferia, pela abrangente malha de transporte e pelo desenvolvimento de uma cultura pop internacional; as grandes cidades propiciaram a formação das inscrições urbanas.

Paris e Nova Iorque destacaram-se como as duas metrópoles que permitiram a formação das inscrições urbanas como prática social. Contudo vale ressaltar o pioneirismo de alguns artistas franceses por sua produção concebida para o espaço público. Nessas obras, o espaço deixava de ter um papel de mero suporte para ser destacado por seus próprios conteúdos. Essas intervenções eram pontuais em relação ao trabalho do artista, uma vez que não havia uma continuidade desses projetos, porém elas anteciparam e influenciaram as reflexões sobre arte urbana e espaço público nos anos de 1980.

Uma das primeiras iniciativas que incorporaram o espaço urbano à obra foi o projeto affiches lacérées (cartazes rasgados) dos artistas Raymond Hains e Jacques Villéglé na década de 1950. A bricolagem de resíduos publicitários nos muros da cidade era convertida em forma artística (semelhantemente à técnica de Kurt Schwitters), mas colocada no espaço público, produzia um efeito de camuflagem urbana, porque seria difícil distinguir o objeto de arte da publicidade cotidiana. A recepção da obra exigia certa competência do observador para identificar a obra entre as centenas de cartazes espalhados por Paris ou, talvez, para apurar seu olhar sobre a cidade e sobre o objeto artístico.

Figura 1 - Ach Alma Manetro (1949)

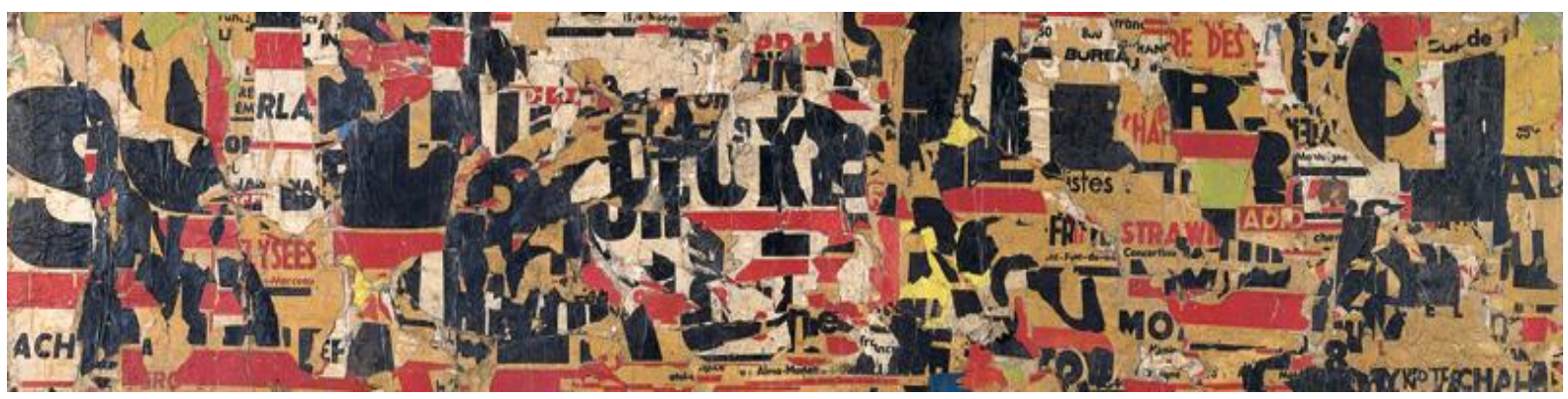

(HAINS; VILLEGLÉ, 2016) 
Ernest Pignon-Ernest é outro artista vanguardista no que se refere à prática das inscrições urbanas. Seus cartazes diferenciavam-se por dar relevância ao espaço, enquanto a maioria dos cartazes o empregava como suporte indiferenciado. Ombres projetées, seu primeiro projeto de arte urbana, foi inspirado no caso de Hiroshima e Nagasaki. Por causa da bomba atômica, as sombras de seus habitantes tornaram-se uma forma de inscrição no solo dessas cidades:

Pelo poder luminoso da explosão atômica e pelo efeito térmico, a sombra dos habitantes foi impressa no chão, como um negativo. $\mathrm{O}$ clarão agiu como um aparelho fotográfico e um obturador, o ser humano como tema e o chão como película sensível. Essas sombras preservaram os muros da incineração e, inversamente, o chão marcado foi o monumento de sua memória, mesmo que atualmente ele tenda a desaparecer ${ }^{4}$ (GENIN, 2013, p. 85-86, tradução própria).

Os cartazes pertencentes a esse projeto eram feitos a partir de fotografias e inscritos sob a forma de lambe-lambes em locais precisos, cuja significação se constituía na relação com o espaço, ou indiretamente em suportes móveis. Por exemplo, a intervenção L'origine nos arredores das instalações de lançamento de mísseis atômicos situadas no Plateau d'Albion na França, em 1966.

Figura 2 - L'origine (1966)

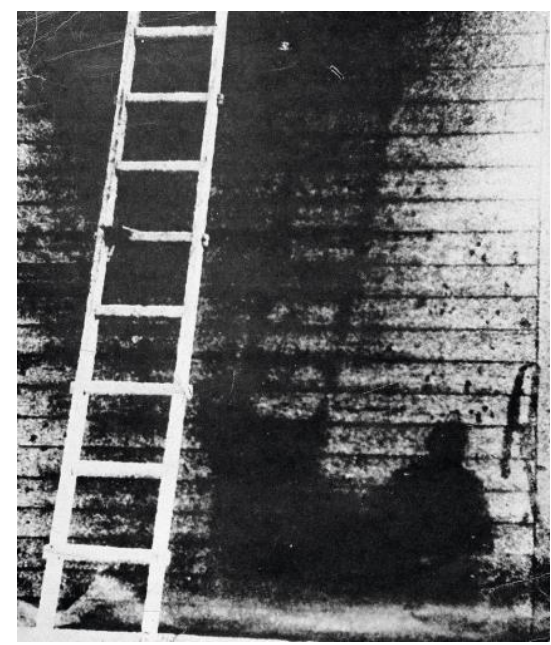

(PIGNON-ERNEST, 2015)

\footnotetext{
${ }^{4}$ Par la puissance lumineuse de l'explosion atomique et par l'effet thermique, l'ombre des habitants s'est imprimée sur le sol, comme en négatif. L'éclair agit comme un appareil photographique et un obturateur, l'être humain comme sujet, et le sol comme une pellicule sensible. Ces sombres ont préservé les murs de la brûlure et inversement le sol marqué fut le monument de leur mémoire, même s'il tend actuellement à s'effacer.
} 
Outro veterano da cena europeia da arte urbana, Gérard Zlotykamien, "viveu numerosas disputas a propósito da Street Art desde os anos de 1960 e que as acompanhou com as suas próprias representações" (STAHL, 2009, p. 95). Seus desenhos, de traços simples feitos em spray, criavam formas orgânicas com cabeças flutuantes que provocava um efeito de imagem infantil. No entanto a série Éphemere (1961) diluía essa temática naïf do traçado em uma ampliação das possibilidades de leitura oferecidas pelo título. O motivo fugacidade atualizava-se nessas linhas infantis e de acordo com o lugar em que se encontrava a obra, temas sobre a condição do homem e da própria obra eram manifestados.

Figura 3-Éphemere de Gérard Zlotykamien

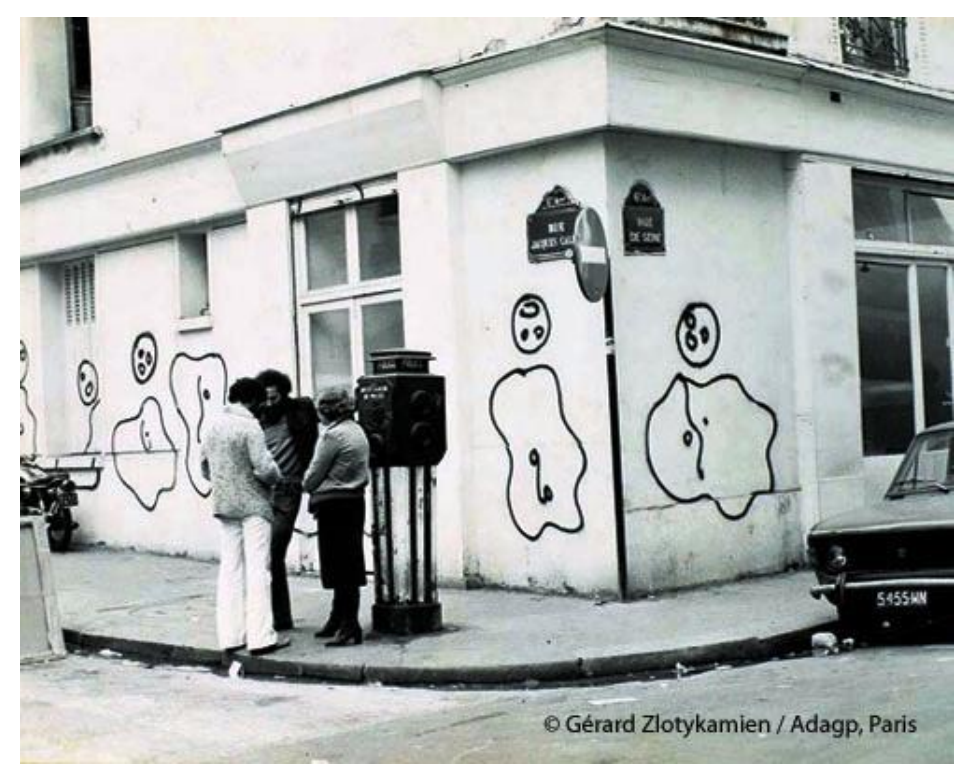

(ZLOTYKAMIEN, 2015)

Mais um destaque desse período vanguardista para as inscrições urbanas foi a obra Rideau de Fer (1961-1962) de Christo e Jeanne-Claude: instalação formada por uma parede de latões de ferro empilhados, que criou um bloqueio na Rue Visconti, em Paris. Além de intervir diretamente no espaço público, o que obrigava o pedestre a "enfrentar" a obra, Rideau de Fer remontava uma prática marcante na história da França revolucionária.

Posteriormente a esses projetos artísticos individuais, manifestações sociais ligadas à pratica de inscrição urbana eclodiram de modo mais intenso e homogêneo nas cidades de Paris e Nova Iorque, à vista disso: 
A arte urbana, que adquire popularidade no final dos anos de 1960 , viaja entre a América do Norte e a Europa com fluidez e velocidade. Essa arte tem dupla origem. Por um lado, os estudantes universitários da Sorbonne a inauguram em Paris, quando escrevem nos muros da universidade e da cidade, os proclames revolucionários que gritam nas manifestações populares. [...].

Por outro lado, a arte do grafite nova-iorquino fez um percurso diferente. Ela é iniciada por um jovem de origem porto-riquenha, Demetrio, que pichava seu apelido, Taki, e o número de sua casa, 183, nas paredes, nos ônibus, nos monumentos públicos e nas estações de metrô ${ }^{5}$ (ÁNGELA LÓPEZ, 1998, p. 176-177, tradução própria).

No célebre Maio de 1968 em Paris, os protestos dos estudantes criaram seu próprio meio de expressão. Contra o moralismo familiar, o sistema educacional normativo e contra o sistema político vigente, jovens franceses munidos de sprays imprimiam versos e frases de protesto nos muros da cidade. "É proibido proibir", "A imaginação toma o poder", "As paredes têm ouvidos, os ouvidos têm paredes" foram slogans empregados nesse período, cujos ideais rapidamente se espalharam pelo mundo ${ }^{6}$ (BESANÇON, 2007). A canção de Caetano Veloso "Proibido proibir" (1968) e o poema de Ruy Proença "Tiranias" (2007) são exemplos dessa influência francesa na cultura brasileira.

Figura 4 - Inscrição política Maio de 68

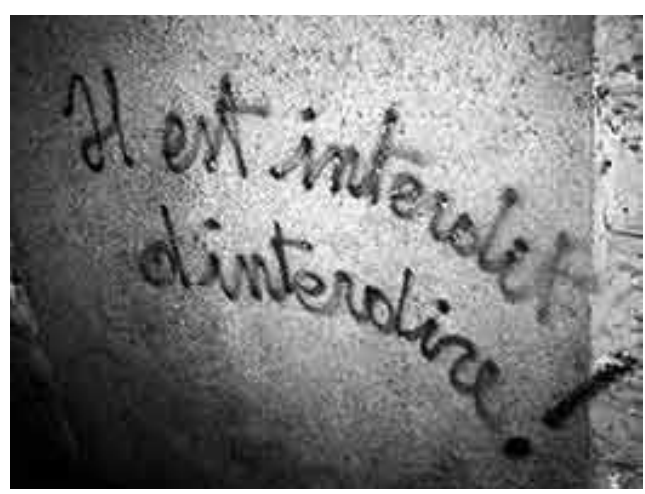

(INVENTIN, 2016)

${ }^{5}$ El arte callejero que adquiere popularidad a finales de los años sesenta de este siglo, viaja entre Norteamérica y Europa con fluidez y velocidad. Tiene doble origen. Por una parte, lo inauguran en París los estudiantes universitarios de la Sorbona, cuando escriben en las paredes de la universidad y de la ciudad las proclamas revolucionarias que vocean en las revueltas callejeras.

El arte del graffiti neoyorquino, por su parte, ha hecho un recorrido diferente. Lo inicia un joven de origen portorriqueño, Demetrio, que garabatea su apodo, Taki, y el número de su casa 183, en las paredes, en los autobuses, los monumentos públicos y las estaciones del metro de Manhattan.

${ }^{6}$ Respectivamente: Il est interdit d'interdire, L'imagination prend le pouvoir e Les murs ont des oreilles. Vos ont des murs. 
O conteúdo político direcionava a elaboração dessas inscrições urbanas, que se concentravam na linguagem verbal, e por meio de jogos de palavras e recursos sonoros, como assonância, aliteração ou paronomásia; os slogans ganhavam maior impacto de recepção. As pichações políticas mobilizavam diversas estratégias discursivas para conseguir maior adesão à causa do movimento estudantil.

Já nos Estados Unidos, a inscrição urbana teve como referência o movimento de Nova Iorque. Apesar de Combread, na Filadélfia, obter o status de pioneiro, foi na Big Apple que as inscrições urbanas alcançaram maior intensidade e continuidade de produção. Essa prática iniciou-se nos anos de 1970 com a propagação de tags por toda a cidade. A $\operatorname{tag}^{7}$ era formada inicialmente por um nome e um número, que correspondiam ao apelido e à numeração da rua do autor, mas conforme a prática foi se estabelecendo na ilegalidade, essas informações pessoais perderam pertinência. Além de ser considerada como "apelido ou outra marca de identificação escrita, como assinatura de um grafiteiro", a palavra tem a primeira acepção de "etiqueta ligada a alguém ou algo para identificar ou dar informação" (OXFORD, 2014, tradução própria), corroborando seu caráter identitário ${ }^{8}$.

Figura 5 - Tags no metrô de N.Y.

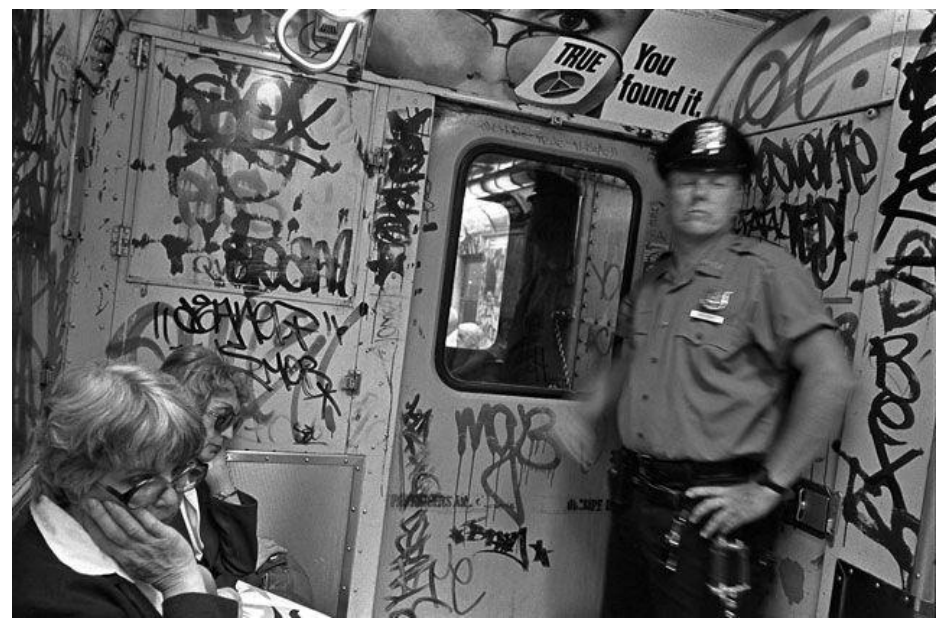

(SANDLER, 2016)

\footnotetext{
${ }^{7}$ Como o artigo the em inglês não define gênero, sua escolha em português deu-se pelo seu uso já estabelecido na bibliografia especializada.

${ }^{8}$ 1. A label attached to someone or something for the purpose of identification or to give other information; [...] 1.3 A nickname or other identifying mark written as the signature of a graffiti artist.
} 
Ligada a um fenômeno social, a tag representava uma demarcação espacial para uma dominação simbólica de uma pessoa ou de um grupo, constituído basicamente por adolescentes. Quanto maior a disseminação da assinatura, mais fama o inscritor ou o grupo conseguiria. Esse movimento tomou ruas e trens nova-iorquinos e alcançou grande notoriedade pela figura de Taki 183 que, devido à excessiva reprodução de sua tag, foi capa de uma seção do The New York Times (CHARLES, 1971).

Figura 6 - Taki 183 no The New York Times

\section{ت્He Alew Hork Eimes}

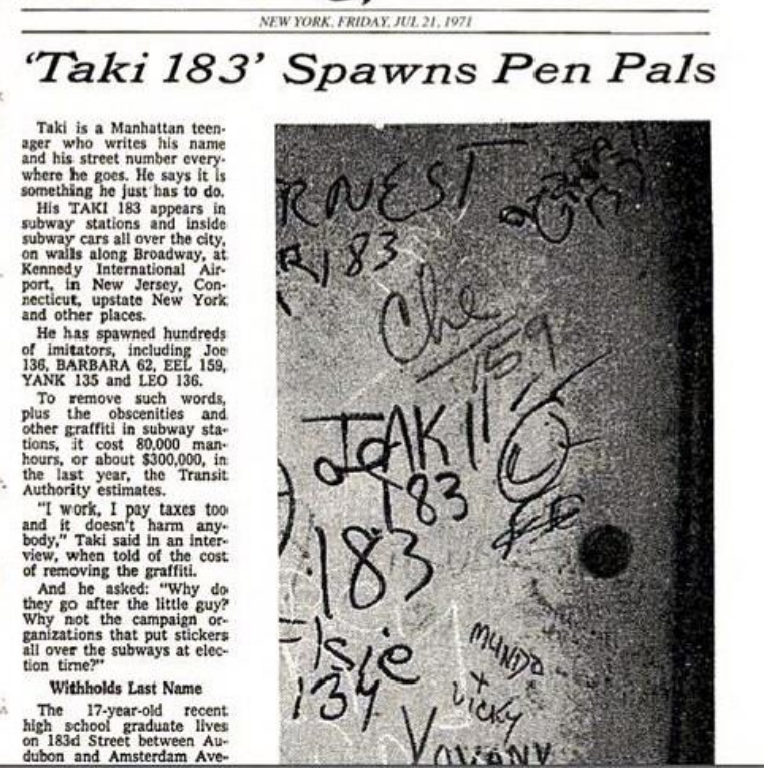

(CHARLES, 1971)

Contudo a tag entrou em um processo de saturação, porque sua demasiada repetição e semelhança estética já não propiciava a autenticidade almejada por seus criadores. Por causa dessa insatisfação, surgia o throw-up, constituído de letras arredondadas e duas cores - uma cor fazia o fundo e a outra o contorno das letras. No entanto sua repetição excessiva em suportes indiscriminados seguia os princípios da tag. Apesar de o modo de difusão ser mantido, a variação estilística do throw-up apontava para uma valorização da qualidade estética em detrimento da quantidade, o que marcaria as modalidades de inscrição urbana posteriores. 
Esse processo iniciado pelo throw-up levou a uma valorização do estilo individual e a uma sofisticação da peça ${ }^{9}$, resultando em um novo estilo. $\mathrm{O}$ emprego de cores e figuras, a elaboração de uma tipografia original e o uso dos vagões de metrô como suporte formavam a modalidade grafite, que voltaria a oferecer a possibilidade de prestígio almejado pelos sprayers. A afirmação de identidade migrava da quantidade de assinaturas para um aumento no grau de elaboração do desenho e da escolha do suporte. Enquanto as tags produziam o impacto no observador pelo número excessivo de assinaturas repetidas, sem se importar com o tipo de suporte; o grafite construiu-se pela perspectiva da qualidade e pela escolha do suporte mais adequado. Os vagões passaram a ser o principal suporte para a obtenção da fama, pois os grafites eram levados pelos trens a inúmeros lugares, difundindo seu impacto na cidade.

Figura 7 - Throw-up de JOZ

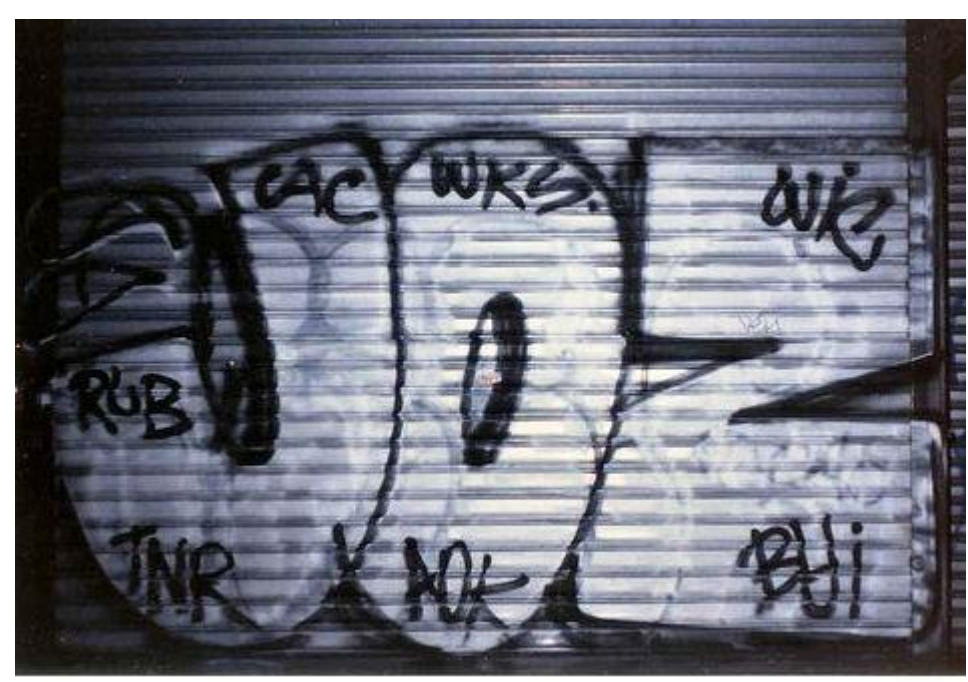

(THE ALL TIME KINGS OF NEW YORK GRAFFITI, 2012)

Diferentemente do grupo parisiense, os grafiteiros nova-iorquinos privilegiavam a forma plástica em suas obras. Havia menos um caráter político na execução das obras que a promoção de competências artísticas. O plano da expressão da linguagem era reforçado. Apesar da criação de obras singulares nos metrôs da cidade, grande parte da população encarava o fenômeno como um ato de vandalismo. De fato, não havia autorização para grafitar nos metrôs e toda produção era realizada ilegalmente: os grafiteiros invadiam as garagens dos vagões para fazer suas obras na

\footnotetext{
${ }^{9}$ Do inglês piece, significa uma obra de inscrição urbana.
} 
madrugada. Essa prática cresceu de tal maneira que, em meados dos anos de 1970, houve uma enorme concorrência entre os grafiteiros e os vagões eram disputados acirradamente. Ao mesmo tempo, a prefeitura de Nova Iorque iniciou uma campanha para eliminar os grafites do metrô. Dentre as medidas tomadas, destacaram-se: a sistemática e rápida remoção das peças, o aumento da segurança nas garagens e da pena para os infratores (STYLE WARS, 1984). Conquanto o gasto enorme no orçamento público, a prefeitura logrou parcialmente seus objetivos, já que não acabou com o grafite, que se desenvolveu pela apropriação dos muros da cidade para prosseguir com seus objetivos: o ibope ${ }^{10}$.

Figura 8 - Cartaz contra tag no metrô

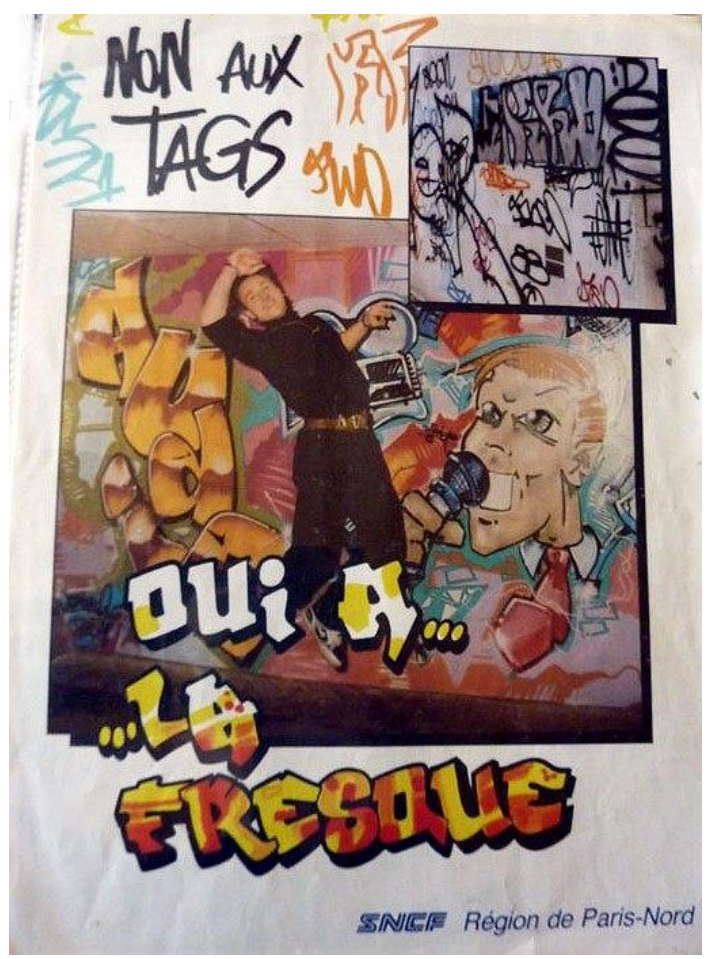

(DARCO, 2010)

O mesmo processo de rejeição do grafite pelo poder público pode ser revisto em diferentes épocas e em diferentes países. Na França, com a inserção feita por Bando do grafite nova-iorquino em Paris (tratado mais adiante), as empresas responsáveis pelo transporte público, Régie Autonome des Transports Parisiens (RATP) e a Société

\footnotetext{
${ }^{10}$ Do inglês getting up , que significa fazer-se perceber, destacar-se. Para manter a equivalência do uso social do vocábulo, será usado "ter ibope" ou "ganhar ibope", pois esta é uma das expressões usadas pelos inscritores brasileiros nesse caso.
} 
Nationale des Chemins de fer Français (SNCF), dispenderam recursos para apagar os grafites nos metrôs de Paris e punir os infratores, obtendo resultados parecidos aos de Nova Iorque (GENIN, 2013, p. 145-150). No Brasil, a Lei Cidade Limpa (SÃO PAULO, 2006), outorgada em São Paulo, é o caso mais recente de controle do espaço público, pois suas diretrizes determinam a regulamentação sobre a visualidade da metrópole. As repercussões dessa lei afetaram enormemente a produção das inscrições urbanas na cidade nos anos 2000 (CIDADE CINZA, 2013).

Ainda na ilegalidade, pode-se dizer que o grafite beneficiou-se da mudança de suporte, pois, com a utilização dos muros, havia mais tempo para a produção da peça e já era possível realizá-la à luz do dia, o que propiciava um refinamento artístico das obras. Esse aumento no tempo de execução foi profícuo para a diversificação dos estilos, para o aprimoramento estético e para a fixação do grafite como um fenômeno artístico substancial. Nesse momento, artistas plásticos perceberam no grafite uma técnica eficaz para o desenvolvimento de seus trabalhos, como também um modo de afastar-se dos museus e aproximar-se da sociedade com esse novo tipo de arte pública.

Aliada à vertente que considera Paris e Nova Iorque como representantes de dois núcleos estruturantes das inscrições urbanas, nossa proposta exclui cidades aparentemente importantes para o movimento das inscrições urbanas. A eleição dessas cidades tem maior pertinência, porque houve uma alta intensidade produtiva associada a fenômenos sociais, que as expuseram para todo o mundo, tornando-as uma referência.

\subsection{BREVE HISTÓRIA DAS INSCRIÇÕES URBANAS: (R) EVOLUÇÕES}

Os grafites precursores de Paris e Nova Iorque viraram referência e seus desdobramentos criaram as diversas modalidades de inscrições urbanas. Depois do Maio de 1968, seguiu-se uma vertente política ligada a artistas e intelectuais, e outra mais voltada ao grafite marginal em Paris. De um lado, os artistas perceberam no grafite uma boa ferramenta para produzir arte pública; de outro, uma ala mais rebelde da juventude reconheceu nesse fenômeno um excelente modo de afirmação de identidade. Em consequência disso, o grafite artístico obteve maior destaque por sua 
inventividade que o grafite juvenil. O primeiro buscava a exploração de formas harmoniosas em relação ao espaço, aproximando o enunciatário; o segundo empregava uma transgressão do espaço, afastando o enunciatário. O grafite artístico diversificava seus materiais, suportes e temas, já o grafite marginal, importador da estética estadunidense, mantinha seu estilo repetitivo e uniforme.

O espaço dos coletivos artísticos concentrava essas duas vertentes. A liberdade da palavra no muro, a comunicação direta com a população e a interação da obra com o espaço público, propiciadas pelas inscrições urbanas, interessavam a esses coletivos, pois seus ideais de liberdade, equidade social e sua produção artística conceitual confluíam na direção do grafite. Os movimentos Punk, Okupa, Zig-Zag, FBI e Fluxus são alguns exemplos desses coletivos que viam no grafite uma ferramenta para exercer a liberdade de expressão almejada.

Figura 9 - Movimento Okupa (Tacheles)

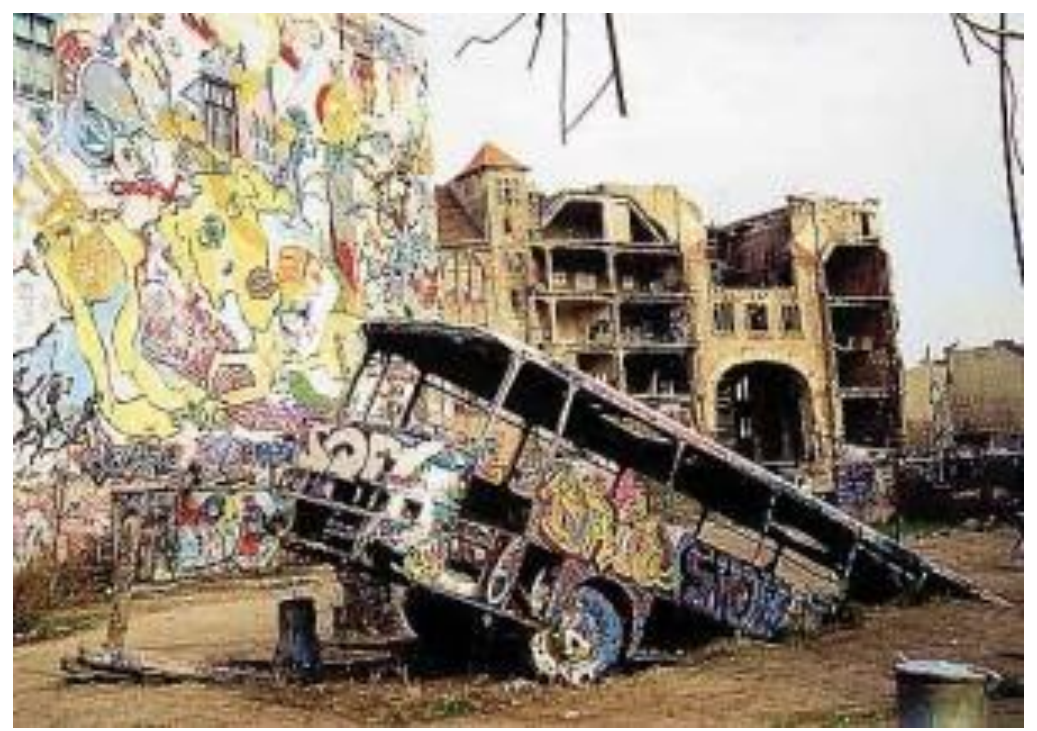

(MCCONNELL, 2013)

Em Nova Iorque, o grafite, fortemente ligado a uma cultura marginal, estabeleceu sua linguagem e criou suas regras sociais ao longo dos anos de 1970, mas a perseguição das autoridades forçou-o a migrar de suporte: dos trens para os muros. Essa adaptação elevou o nível de acabamento das obras, criou estilos, revelou novos artistas, estabeleceu uma cultura do grafite e seus principais nomes. A inserção de figuras e o desenvolvimento tipográfico caracterizaram sua visualidade nessa década. O desenvolvimento dos estilos de letras e a inclusão de desenhos figurativos, como 
super-heróis, referências artísticas ou ilustrações originais, formavam a obra. Em síntese:

\begin{abstract}
Uma marca (tag) é o nome escolhido, e embora esteja no nível mais abaixo na escala de habilidade, ainda assim, é muito importante. A seguir, vem o throw-up (vômito); são duas letras do nome, em duas cores, sendo uma o contorno, a outra o preenchimento. A isso se segue o $d u b$, o nome completo em duas cores. Em seguida, vem a piece (peça ou obra), ou masterpiece (obra-prima), na qual o nome elaborado é pintado sobre um fundo que às vezes é quase ou igualmente elaborado. Depois, vem o wild style (estilo selvagem), um quebra-cabeça tipográfico [...]. Finalmente, vem a production (produção) - geralmente em tamanho bem maior - e muitas vezes feita por uma equipe (crew) ou gangue de amigos (ELLSWORTHJONES, 2012, p. 43).
\end{abstract}

Socialmente, o inscritor dependia do reconhecimento de seus pares, ou seja, o status do grafiteiro era elevado conforme as obras, feitas à mão livre, fossem mais complexas, sua localização fosse destacada e se houvesse uma grande quantidade de obras suas espalhadas pela cidade. Artistas como Lee, Phase II e Seen contribuíram para o estabelecimento do grafite, chegando aos anos de 1980 com o prestígio de pioneiros (Old School). A partir de então, o grafite começou gradualmente a ser aceito como arte.

Nessa nova década, os vagões e os muros já não eram mais o suporte exclusivo do grafite; o quadro passou a fazer parte da produção desses artistas. Emolduradas, as obras das ruas começaram a integrar os catálogos das galerias de arte. Esse fenômeno não somente ofereceu um caminho legal para a realização do grafite como obra de arte, mas também o colocou no mercado. A junção entre grafite e arte, característica dos anos 1980, deu-se em uma dupla conversão: grafiteiros foram alçados à condição de artistas plásticos e artistas plásticos viram no grafite uma ferramenta de trabalho. Desse modo, a rua foi até os museus e o ateliê foi às ruas.

A diferença entre Estados Unidos e Europa é significativa nessa inserção do grafite no mercado de arte. Enquanto os inscritores europeus geralmente possuíam uma formação acadêmica, os grafiteiros estadunidenses, em sua maioria, não a possuíam. Essa diferença interferiu na maior facilidade dos artistas europeus para integrar o mercado de arte e constituir uma sólida carreira artística, se comparado aos novaiorquinos, que, em sua maioria, não estavam preparados para essa nova perspectiva. 
Outra diferença marcante nos estilos dos dois continentes nesse período referiase ao uso da técnica do estêncil ${ }^{11}$. Nos Estados Unidos, a prática do grafite criou suas normas, dentre elas, prescrevia-se que o grafiteiro deveria realizar seu trabalho à mão livre, o que significava utilizar nenhum instrumento além do spray. Fitas adesivas, linhas, cartões, estêncil etc. não poderiam ser empregados para auxiliar a produção do grafite, pois isso rebaixaria o artista ao status de toy (artista iniciante). Na Europa, ainda que aceito no mercado de arte, o grafite executado nas ruas era geralmente ilegal. Com o uso do estêncil, preconizado pelo francês Blek le Rat, havia menor risco de o artista ser flagrado em sua atividade não autorizada, pois essa técnica possibilitava a rápida execução do grafite, por permitir a preparação do trabalho com antecedência.

Muitos artistas europeus foram influenciados não somente pela técnica empregada por Le Rat, mas também pelo uso de sua iconografia pop. Jef Aerosol e Speedy Graphito, pioneiros na arte de rua europeia, seguiram a herança de Andy Warhol atualizada por Blek le Rat, estampando ícones da cultura pop pelos muros das cidades. Figuras de Tom Waits (Le Rat), Elvis, Gandhi (Jef Aerosol) e Mickey Mouse (Speedy Graphito) foram reproduzidas pelos artistas por toda Europa. Le Rat apropriou-se do conceito de reprodutibilidade da Pop Art para criar seu próprio ícone, o rato, e inseri-lo nesse circuito de imagens-pop.

Figura 10 - Blek le Rat, Paris 1981

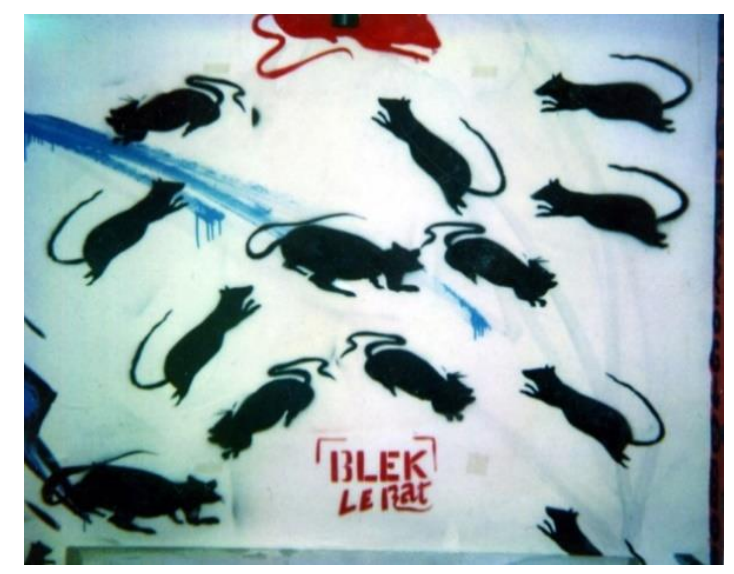

(BLEK LE RAT, 2016)

\footnotetext{
${ }^{11}$ Também conhecido como máscara, o estêncil é um molde elaborado pelo artista. Em um papel rígido, faz-se o desenho por cortes para que a parte vazada sirva de negativo. Terminado, o molde é colocado na superfície e o artista passa a tinta sobre o papel, assim, somente o desenho da parte recortada permite que a tinta seja aplicada à superfície.
} 
Miss. Tic e Jérôme Mesnager também seguiram a técnica preconizada por Le Rat, investindo na própria criação icônica. Miss. Tic ligou-se à tradição do Maio de 68 , ao priorizar os recursos poéticos da linguagem verbal em seus grafites, formados por frases poéticas, figuras ou pela mistura de ambos, por exemplo, em "contra a parede / a cor sofre / o amor se apaga" e "o acaso / baba / fórmulas / de magia negra" (MISS.TIC, 2014) ${ }^{12}$. Já o trabalho de Jérôme Mesnager é marcado pela série de imagens de figuras humanas, caracterizadas pela ausência de rostos, pela nudez e pela ênfase em seus músculos.

Figura 11 - "Le hasard bave des formules de magie noire" de Miss. Tic.

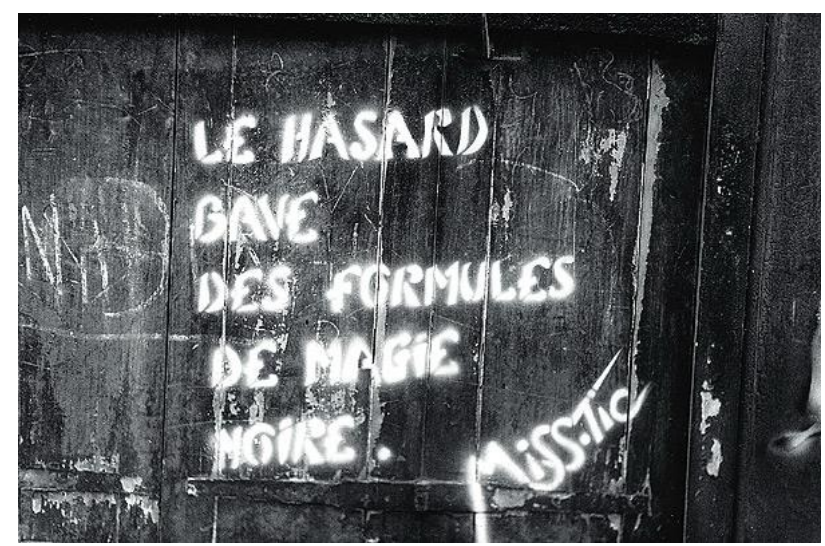

(MISS.TIC, 2014)

Figura 12 - "An eye for an eye makes the whole world blind" de Jef Aerosol

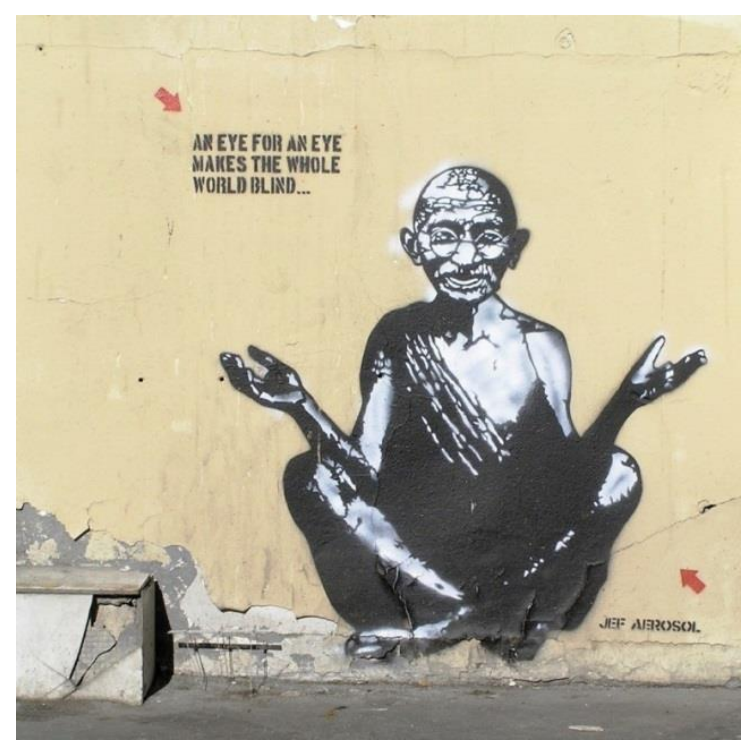

(QUOTES LINKS, 2016)

\footnotetext{
${ }^{12}$ Au pied du mur couleur soufre l'amour s'eteint e Le hasard bave des formules de magie noire.
} 
Figura 13 - Obra de Jérôme Mesnager

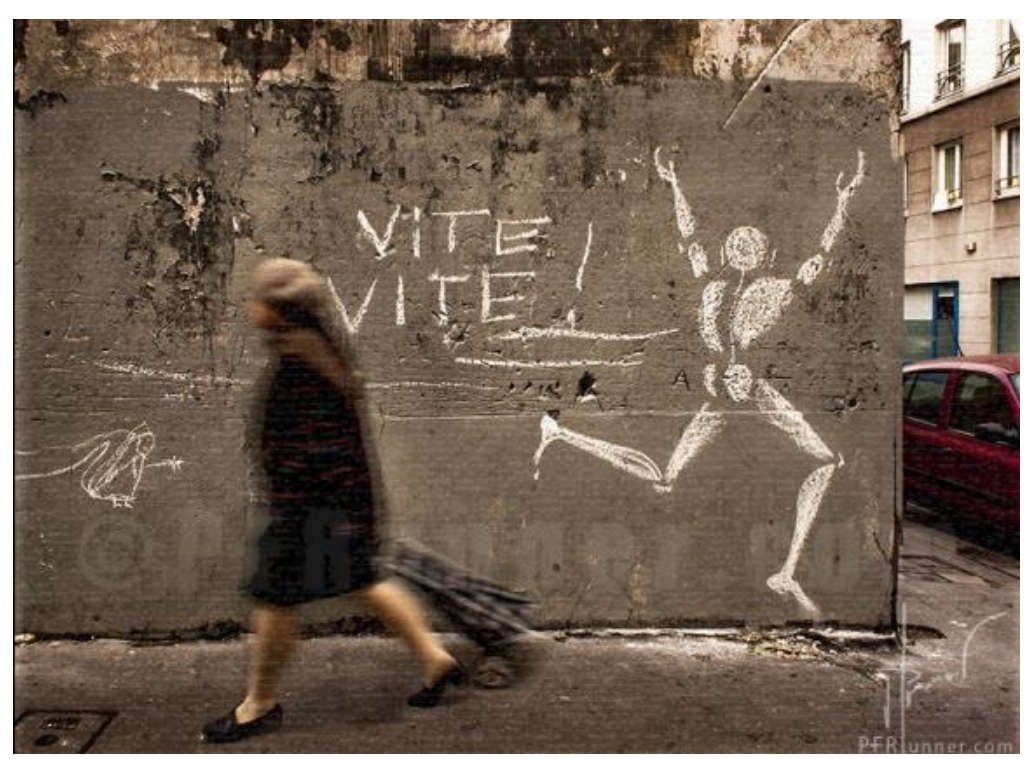

(PONOSOV, 2013)

No contraponto do estêncil, artistas na linha de Gérard Zlotykamien destacamse na cena europeia pela simplicidade dos seus desenhos à mão livre, como o artista suíço Harald Naegeli, cujos grafites são formados por linhas contínuas, monocromáticas e feitas com spray. Diferentemente de Nova Iorque, essa execução do grafite à mão livre marca a subjetividade do artista em seu traço: o gesto é mais importante que a afirmação de sua habilidade.

Figura 14 - Obra de Harald Naegeli

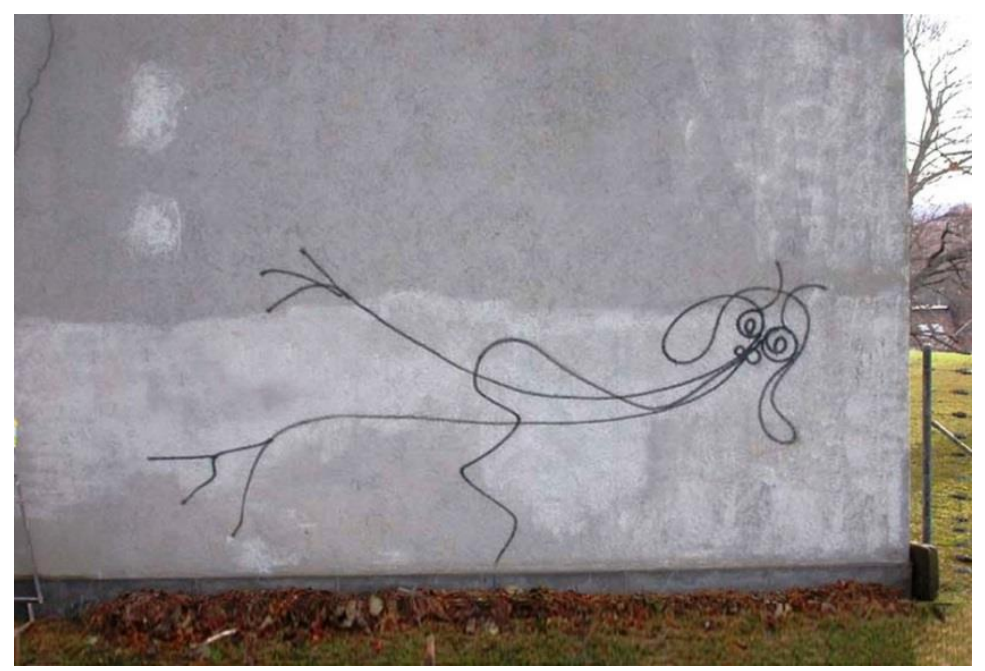

(SEAN, 2009) 
Essa apropriação intelectual das inscrições urbanas em Paris não eliminou a vertente mais próxima do estilo de Nova Iorque e foi na figura de Bando que o grafite old school se estabeleceu na Cidade Luz. Devido às suas viagens à Nova Iorque, Bando teve contato com o grafite e lá aprendeu a técnica e o estilo de vida com os mais destacados grafiteiros, como Seen, Dondi, Taki 183 e com um dos fotógrafos mais importantes da Street Art, Henry Chalfant. Ao retornar à Paris, ele inicia suas primeiras tags em território europeu e desenvolve sua técnica até consolidar seu estilo no lettering (grafite que valoriza a tipografia). Além de ser o responsável pela inserção dessa prática em solo francês, Bando estabeleceu uma rede de contatos que permitiu a visita de artistas de outros países à Paris, como o grupo britânico TCA (The Chrome Angels), cujo integrante mais famoso era Mode 2.

Figura 15 - Bando: grafite old school

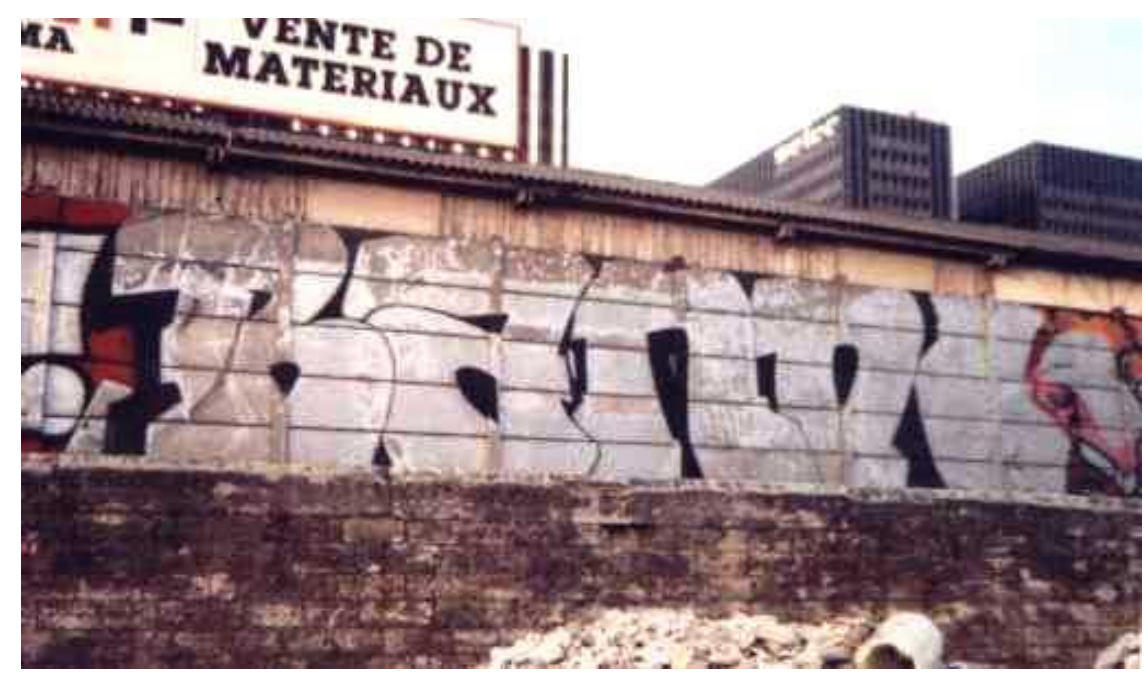

(BANDO CENTRAL, 2016)

Após a solidificação do grafite old school e do inquestionável talento de Bando para desenvolver um estilo próprio, inicia-se um movimento de inserção desse grafite nas galerias de arte e museus, semelhantemente ao que ocorreu em Nova Iorque. Bando mais uma vez ocupava o lugar de destaque no estabelecimento do grafite marginal em Paris, ao aplicar suas variações tipográficas em cor prata - uma marca de seu trabalho - em tela, ele expandiu as possibilidades do grafite marginal para o 
mundo da arte. Por exemplo, em sua obra Les nymphéas du graffiti que reinterpreta os célebres painéis de Claude Monet ${ }^{13}$.

Figura 16 - Obra em tela de Bando "Coltraine"

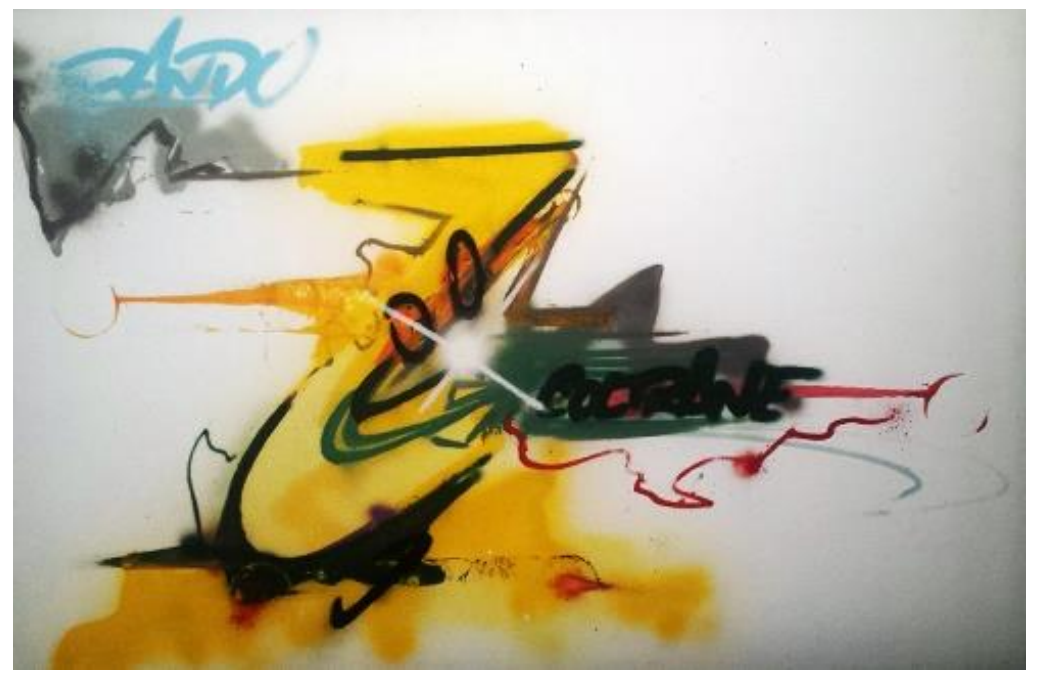

(PINACOTHÈQUE DE PARIS, 2015, p. 163)

Fora do cenário europeu, a inserção dos grafiteiros no mundo da arte e dos artistas plásticos no mundo do grafite é mais marcante nos Estados Unidos. Muitos grafiteiros beneficiaram-se do boom do grafite no mercado de arte. Eles produziram telas, grafitaram muros privados e tornaram-se artistas reconhecidos. Entretanto esse fenômeno gerou uma discussão acerca da essência do grafite: fora das ruas, o grafite seria descaracterizado? A tela seria um suporte adequado para o grafite? Apesar da polêmica, a maioria dos artistas que saíram das ruas para chegar às galerias não considerava grafite seus trabalhos feitos em tela. Talvez, devido ao código de conduta do grafiteiro, fosse necessário separar esses dois espaços, mas mesmo a crítica especializada não aceitava bem a simples transposição de uma obra do muro para a tela. A rápida ascensão do grafite ao mercado de arte não propiciou uma sólida preparação para que os grafiteiros valorizados seguissem suas carreiras artísticas. Alguns souberam adequar-se ao novo desafio, contudo, a maioria foi esquecida tão logo passou o frisson a respeito do grafite.

\footnotetext{
${ }^{13}$ Devido às grandes dimensões desse painel feito por Bando, não é possível reproduzi-lo neste trabalho. Para isso, recomenda-se a consulta do catálogo da exposição sobre grafite Pressionnisme 1970-1990 (PINACOTHÈQUE DE PARIS, 2015).
} 
O nova-iorquino Jean-Michel Basquiat é um exemplo notório dessa adequação. Ele iniciou sua carreira com o grafite, ao estilo Maio de 1968. Sob o pseudônimo de Samo, Basquiat escrevia com spray frases nos muros da cidade de Nova Iorque, porém, foi com sua entrada no mercado de arte que ele se tornou um artista reconhecido. Suas telas e esculturas dialogam com a arte urbana, mas a partir do universo da arte contemporânea. Seu precoce falecimento contribuiu para a valorização do mito do artista marginal em um período de grande apreciação da arte urbana.

Figura 17 - Samo

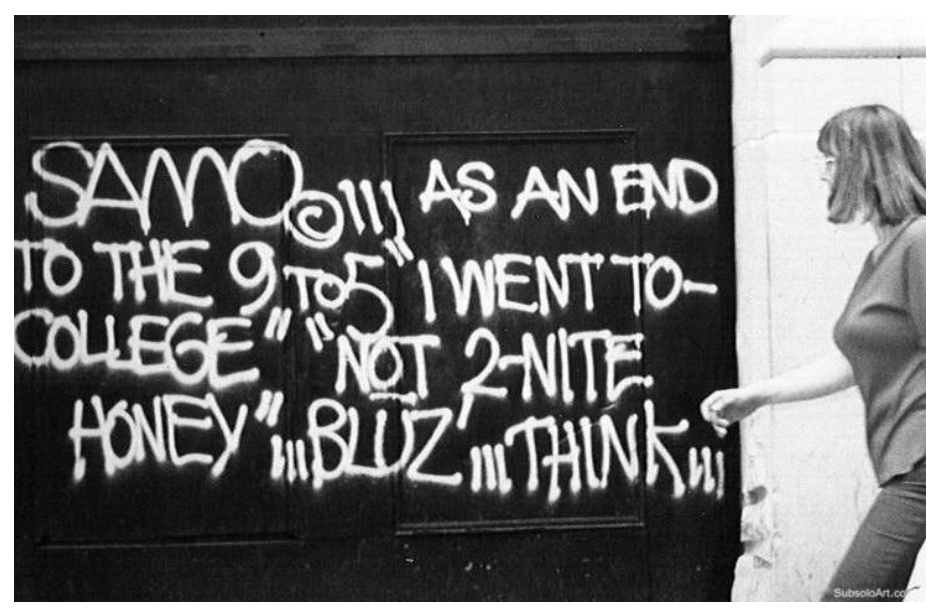

(SUBSOLO ART, 2012)

Figura 18 - Mona lisa (1983)

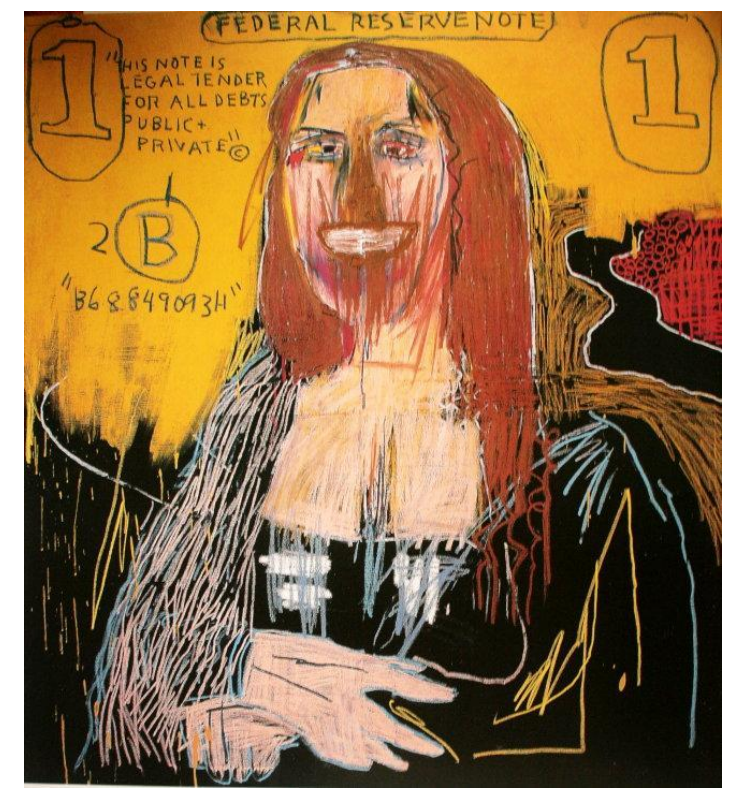

(EMMERLING, 2003, p. 51) 
No mesmo percurso que Basquiat, mas sempre ligado às características do grafite, encontra-se Rammellzee. Um artista experimentalista, que explorou diversas possibilidades na arte urbana, como a gravação de um disco de Hip Hop, cuja capa foi feita por Basquiat. Seus trabalhos de grafite e de arte urbana seguem a mesma linha, adequando-se e explorando as características de cada suporte, porém, sempre relacionado à cultura das ruas.

Figura 19 - Obra de grafite de Rammellzee

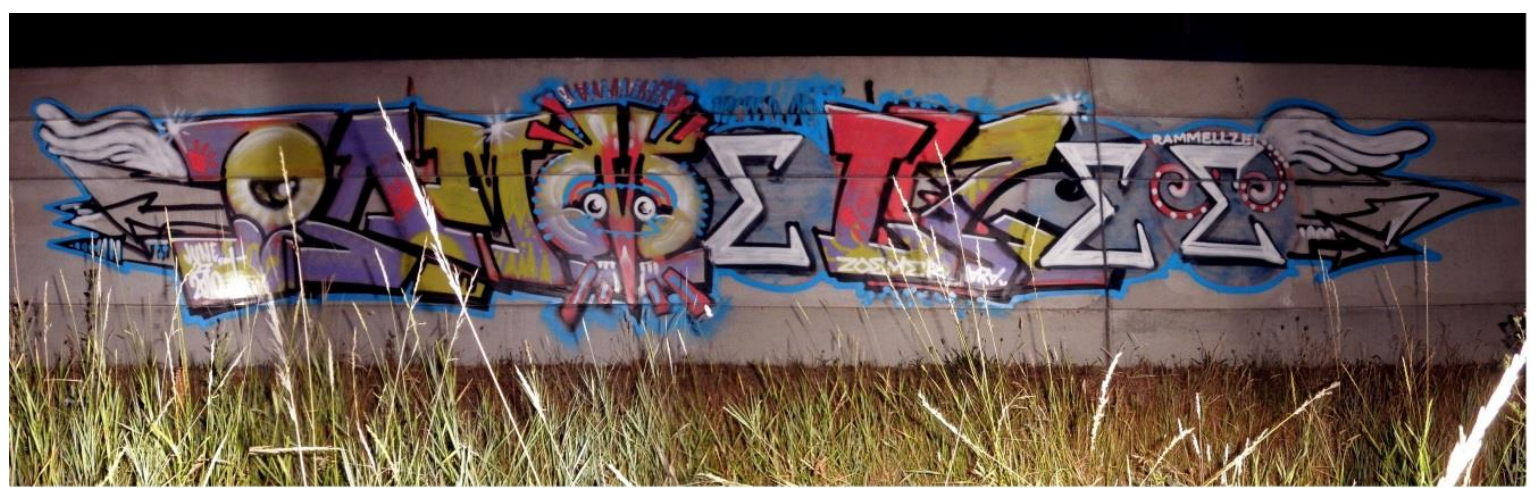

(SUPERRADNOW, 2011)

Figura 20 - Atomic Note Maestro Atmosferic de Rammellzee

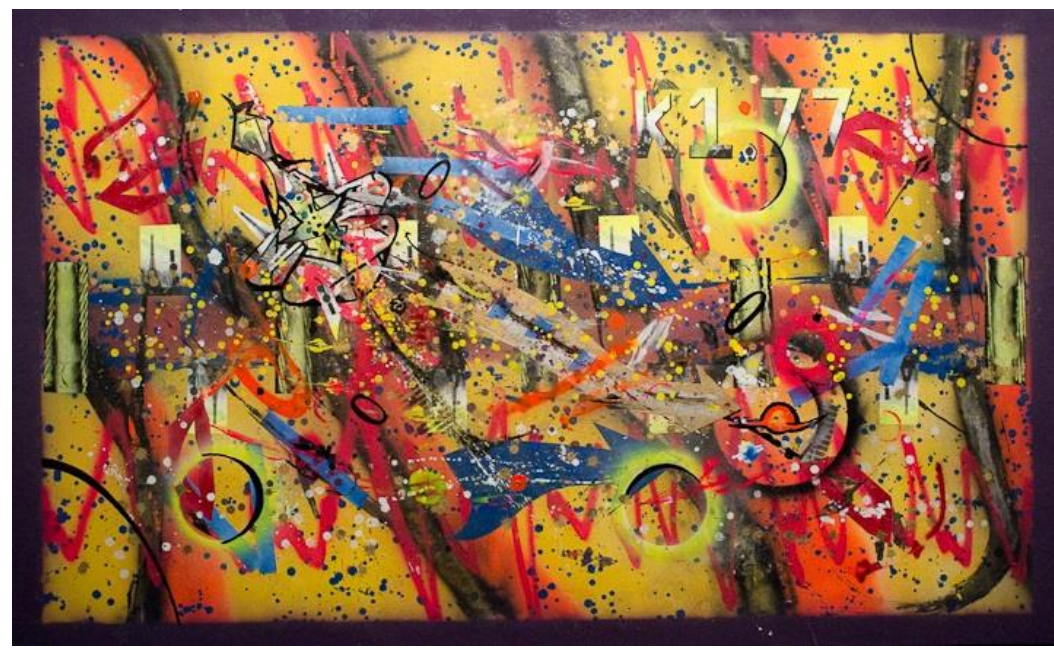

(PINACOTHÈQUE DE PARIS, 2015, p. 169)

No percurso oposto ao de Basquiat e Rammellzee, os artistas estadunidenses Kenny Scharf e Keith Haring viram no grafite uma linguagem pertinente para a realização de suas obras. Seguindo a tendência dos artistas plásticos europeus, Kenny Scharf conciliava o ateliê aos muros da cidade. Em conformidade com o trabalhos de 
Seen e Blek le Rat, sua obra apropriava-se de personagens de desenhos animados e de temas de ficção científica. Sua iconografia era composta pelos futuristas "Os Jetsons", pelos pré-históricos "Os Flintstones" e por monstros alienígenas que ora imprimiam muros, ora figuravam telas.

Figura 21 - Quadro de Kenny Scharf

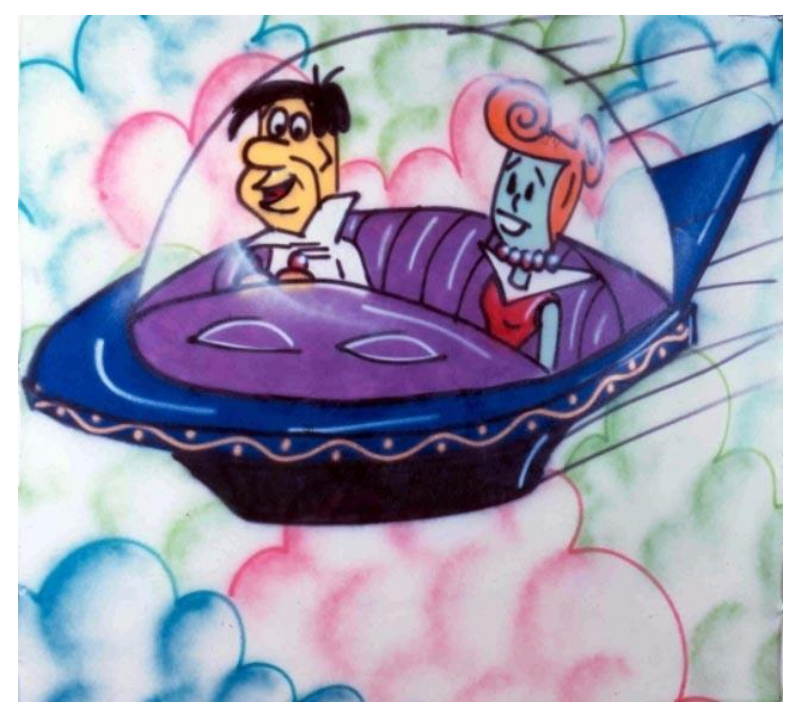

(SHARF, 2016)

Outro artista importante nessa associação da arte urbana com a pintura de ateliê foi Keith Haring. Seu trabalho é marcado pela representação de cenas humanas e pela simplicidade de traços. Na esteira de Gérard Zlotykamien e Jérôme Mesnager, suas imagens hieroglíficas, “estilizadas e graciosamente 'infantis' de bebês engatinhando, cachorros latindo, figuras 'palito' representada com traços retos [...]", alimentavam-se da linguagem da cultura de massas: quadrinhos, televisão, publicidade etc. (LEONZINI, 2003). Além disso, Haring foi um dos precursores da mercantilização de sua própria obra, montando uma loja onde eram vendidos produtos registrados com estampas de seu trabalho artístico.

Nesse contexto do marketing no grafite, o movimento musical do hip hop foi fundamental, pois gerou um estilo de vida (lifestyle) que buscava no grafite uma autenticidade visual. Em consequência disso, empresas começaram a utilizar o estilo grafite para promover seus produtos, contratando os sprayers como desenhistas e ilustradores. Logo, outro caminho profissional surgia para os grafiteiros que se adequavam às galerias e museus. No fim dos anos 1980 e no começo dos 1990, alguns 
grafiteiros abriram empresas na área de publicidade e design para suprir essa nova demanda, por exemplo, Keith Haring ou o grupo francês 123 Klan (fundado por Scien e Klon), responsável pelo design de marcas como Nike, Coca-Cola e Sony.

Figura 22 - Produtos Keith Haring

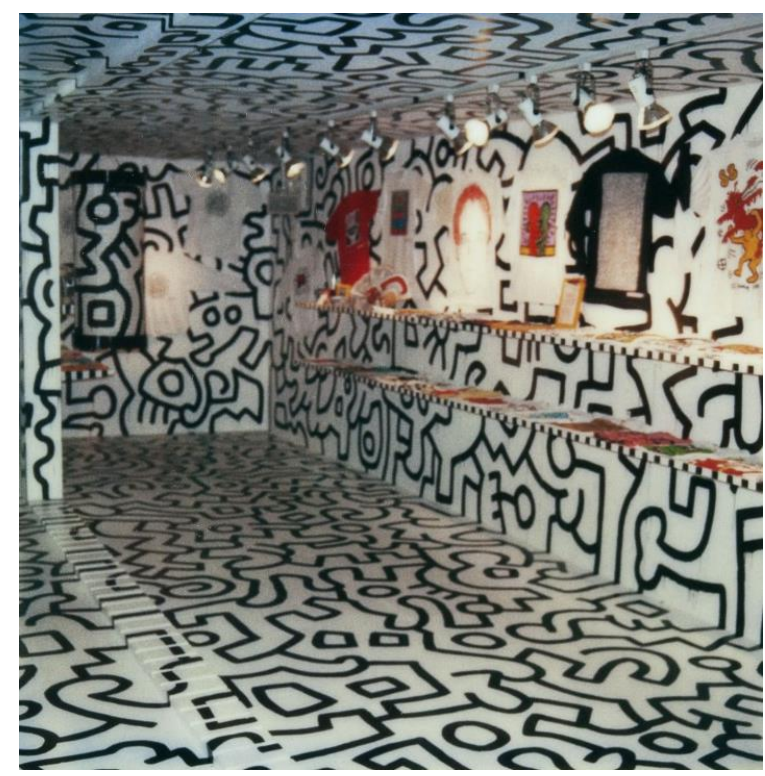

(THE KEITH HARING FOUNDATION, 1997)

Figura 23 - Pôster do filme Wild Style

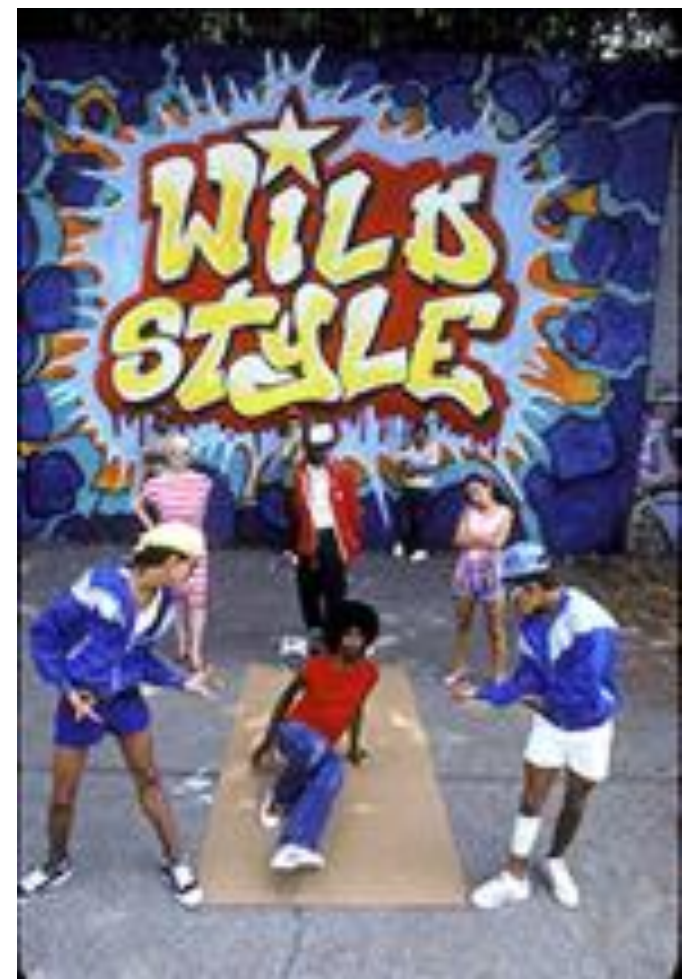

(WILD STYLE, 1983) 
Após os anos 1980, o grafite expandiu sua abordagem de forma acumulativa e ganhou o status de Street Art (arte urbana). Consequentemente, tanto uma tag no metrô, quanto um quadro de Keith Haring podiam ser considerados arte urbana, criando uma enorme dificuldade em sua definição. Foi nos anos 1990 que a arte urbana fortaleceu-se mundialmente por sua variação estética, impulsionada pela geração anterior.

Darco é um representante dessa transformação, pois ao passo que, em 1985, integrava a fundação do grupo FBI, Fabulous Bomb Inability - uma referência de coletivo artístico no grafite - e, em 1989, foi o primeiro grafiteiro condenado por danos ao patrimônio público pela justiça francesa (o que muito contribuiu para a divulgação do FBI); em 1992, Darco conseguiu o título oficial de artista profissional na França, atingindo outro patamar em sua carreira. Em 1994, foi responsável pelos murais na renovação da Estação Norte de Paris (Gare du Nord), importante estação de transportes ferroviários da Europa, consagrando seu trabalho com essa encomenda pública.

Muitos outros artistas afirmaram-se nessa década e muitos suportes foram adotados, contudo, foi nos anos 2000, com a internet, que a criação, o registro e a divulgação das obras tornaram-se mais acessíveis. Criou-se outro espaço de relacionamento entre público e obra, concedendo ao artista maior autonomia. Com isso, houve uma internacionalização da produção artística e já não se pensava mais em termos regionais, porque a recepção das obras tornou-se simultânea.

Para compreender essa equalização entre o cenário local e global, interrompese a sequência dos acontecimentos do final dos anos 1990 para retornar às origens do grafite no Brasil. O desenvolvimento do grafite brasileiro possui algumas características próprias, como o fenômeno da pichação, no entanto, houve um longo período de atraso no diálogo com o movimento internacional, levando a uma imitação tardia. Esse percurso de absorção do movimento internacional, formação da produção nacional e integração ao cenário artístico global será o eixo de amostragem da evolução do grafite brasileiro. 


\subsection{BREVE HISTÓRIA DAS INSCRIÇÕES URBANAS NO BRASIL}

O grafite brasileiro foi formado principalmente nos anos de 1960 e 1970 pela tendência que originou o movimento em Paris: frases estampadas nos muros das capitais brasileiras valorizavam a linguagem verbal. Inscrições pioneiras, como "Abaixo a ditadura!" e a incógnita "Cão Fila Km 26", enfatizavam o plano do conteúdo por diferentes temáticas. O grafite político representava uma vertente mais ligada ao Maio de 1968 e a misteriosa frase revelou-se ser uma propaganda de um canil, situado no quilômetro 26 de uma rodovia em São Paulo.

\section{Figura 24 - Grafite Político e Publicitário}

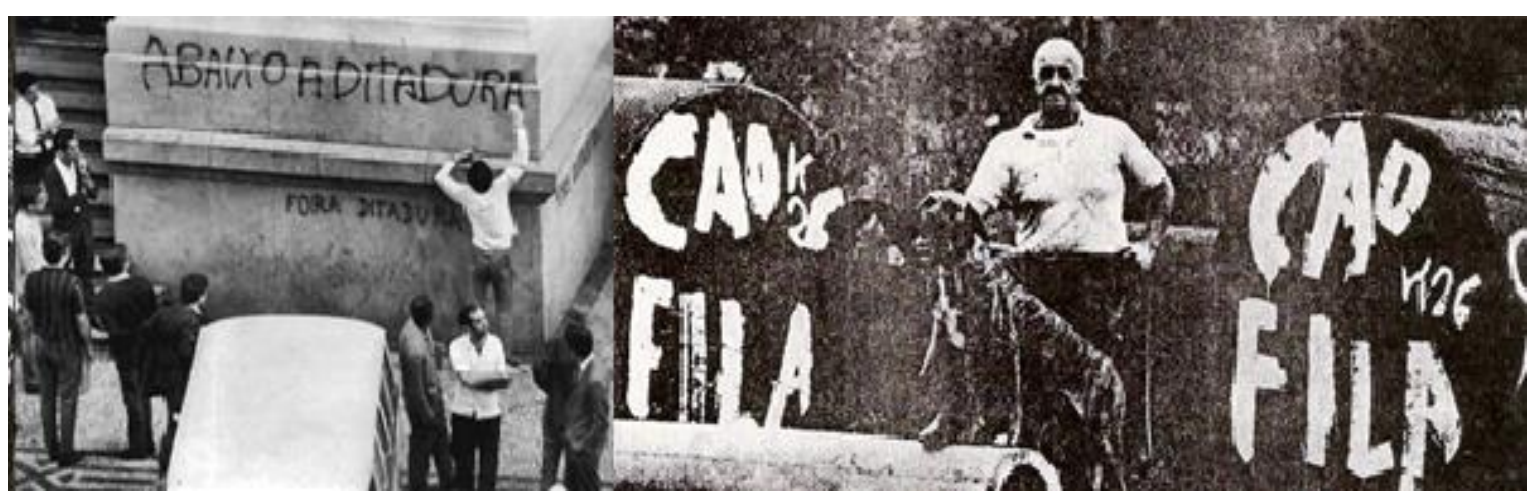

(RESISTENCIA ARQUIVO, 2014) / (BESIDE COLORS, 2015)

Essas práticas precursoras, pouco ligadas às artes visuais, desencadearam um movimento associado à arte poética. Estimulados pela liberdade e pela receptividade que as ruas permitiam, adolescentes e estudantes iniciaram o fenômeno da pichação poética. Frases intrigantes, de duplo-sentido e bem-humoradas exploravam o plano da expressão sonoro da linguagem verbal nos muros das metrópoles, no fim dos anos de 1970. Algumas dessas pichações eram anônimas, como "Celecanto provoca maremoto", "Maria Clara quero a gema" e "Rendam-se terráqueos", outras eram criações de artistas plásticos, como "Hendrix Mandrake Mandrix" de Valter Silveira, "Ora H" de Tadeu Jango e "Ah! Beije-me!" de Hudinilson Júnior (COSTA, 1994, p. 79).

Com a expansão dessa nova prática, as pichações poéticas apropriaram-se das tradicionais pichações políticas, por exemplo, nas frases "Abaixo a vida dura", 
"Anestesia já" e "Viva a UNE, DUNE, TRE!" havia uma imitação das típicas frases de protesto político para criar uma paródia.

Figura 25 - Pichações poéticas

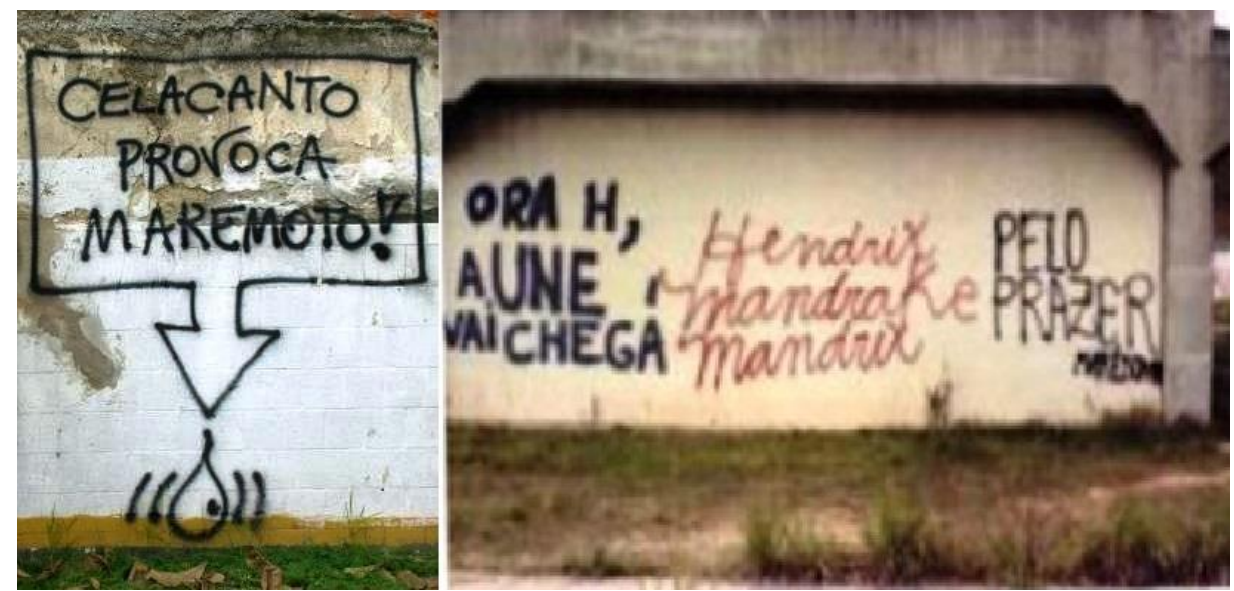

(COSTA, 1994)

Concomitantemente às pichações poéticas, surgia o grafite ligado ao movimento de Nova Iorque: um grafite que enfatizava o plano da expressão visual. A imagem de uma pequena bota feminina de cor preta começou a ser reproduzida em vários espaços da cidade de São Paulo. Da mesma maneira que a propaganda "Cão Fila Km 26", a botinha preta despertava a curiosidade dos transeuntes paulistanos. Pelo depoimento de Hudinilson Júnior (a seguir), pode-se verificar o emprego da técnica do estêncil pelo artista Alex Vallauri, tão cara a Blek le Rat, além da atmosfera misteriosa em torno de sua obra: a bota preta.

[...] Aí eu fiz o AH! BEIJE-ME! Com um macacão que eu guardava o spray dentro do bolso, acabei de fazer, aparece um baixinho loirinho, todo nervoso, me puxa um treco, que depois eu vim a saber que era uma máscara e rapidinho saiu uma botinha! Aí eu olhei essa botinha que eu estava procurando faz tempo! (COSTA, 1994, p. 81).

No caminho de Alex Vallauri, muitos outros artistas contribuíram para o desenvolvimento do grafite artístico. Carlos Matuck e Waldemar Zaidler, que se tornaram colaboradores na obra de Vallauri; Hudinilson Júnior, com seu projeto Narciso - baseado na reprodução de sua própria imagem via estêncil - e cofundador do coletivo 3nós3, responsável por inúmeras intervenções urbanas no fim dos anos 1970; Maurício Villaça, com seus murais de grande extensão; e Ozeas Duarte, com 
suas reproduções de obras primas em estilo grafite, são alguns exemplos da geração grafiteira dos anos 1980 .

Essa afirmação do grafite artístico concretizou-se no Brasil pelo aperfeiçoamento das técnicas, pela maior aceitação do público, pelo reconhecimento da mídia e pelo acompanhamento da tendência internacional de adoção do grafite no mercado de arte, como na obra de Jean-Miguel Basquiat, Keith Haring e Kenny Scharf. Na formação da arte urbana brasileira, o trabalho de Alex Vallauri marcou uma geração. Com diversas exposições e intervenções, sua obra de grafite culminou na participação da $18^{a}$ Bienal de São Paulo (1985), com a instalação Rainha do Frango Assado, cuja construção em forma de residência burguesa mesclava arte urbana, kitsch e pop art. Esse foi um momento de afirmação do grafite como arte contemporânea no Brasil.

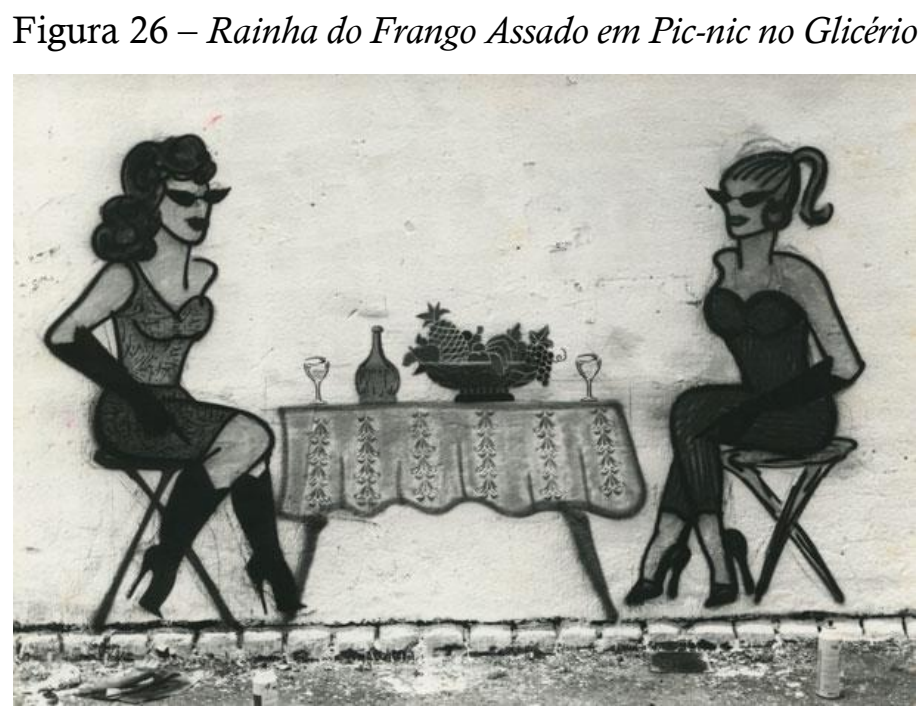

(BIENAL DE SÃO PAULO., 2013)

Outro expoente dessa geração foi o artista Rui Amaral que, juntamente com John Howard, idealizou o Beco do Batman, local de referência para o grafite no Brasil. Além de criar esse museu a céu aberto no bairro da Vila Madalena em São Paulo, Rui Amaral foi responsável pelo surgimento do grupo Tupinãodá, cuja atuação contribuiu para o processo de afirmação do grafite como arte. O grupo promovia o grafite por meio de participações em exposições e, mesmo com a política antivandalismo de Jânio Quadros, realizava grafites à luz do dia, contribuindo para a emancipação da arte de rua. 
Figura 27 - Mural de Ruy Amaral no túnel da Avenida Paulista

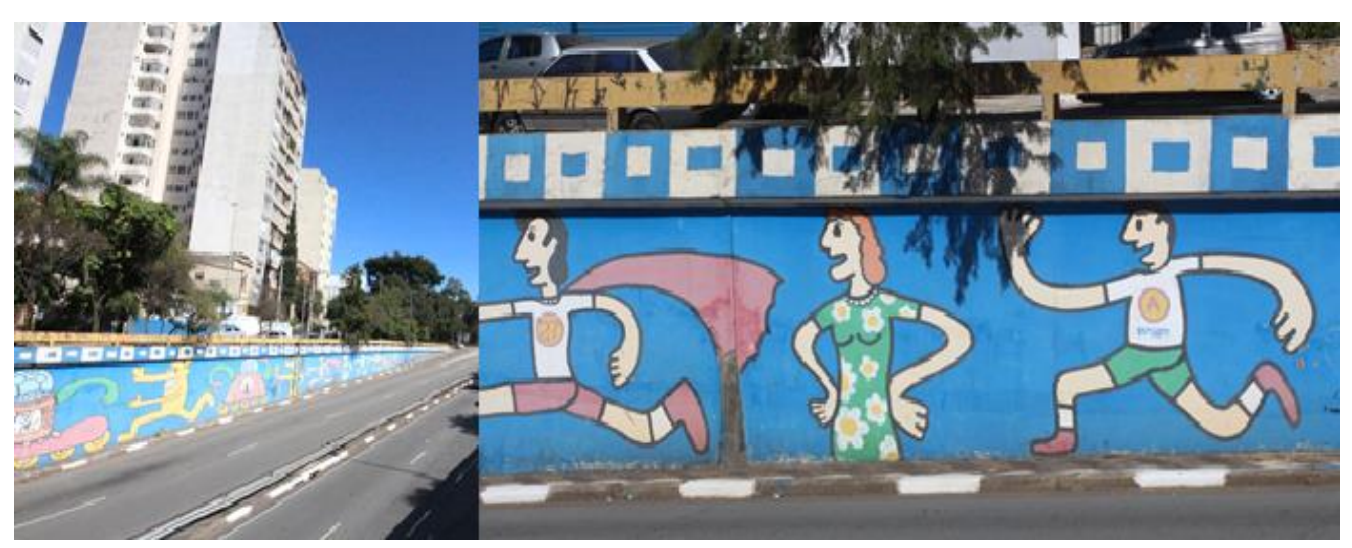

(MAIAN, 2015)

Diferentemente das pichações poéticas e do grafite artístico, outro tipo de inscrição aparecia nos muros de São Paulo; do mesmo modo que a tag procedente de Nova Iorque, a assinatura "Juneca" ou "Juneca e Pessoinha" espalhava-se por todos os muros da cidade. Essa atitude de reprodução de uma mesma marca gerou um movimento paralelo ao grafite. Além da repetição, a alta dificuldade de acesso ao suporte, a proibição do espaço e a evidenciação da assinatura fundamentavam essa nova prática: a pichação.

Figura 28 - Picho de \#DI\#, Skiti e $M N B$

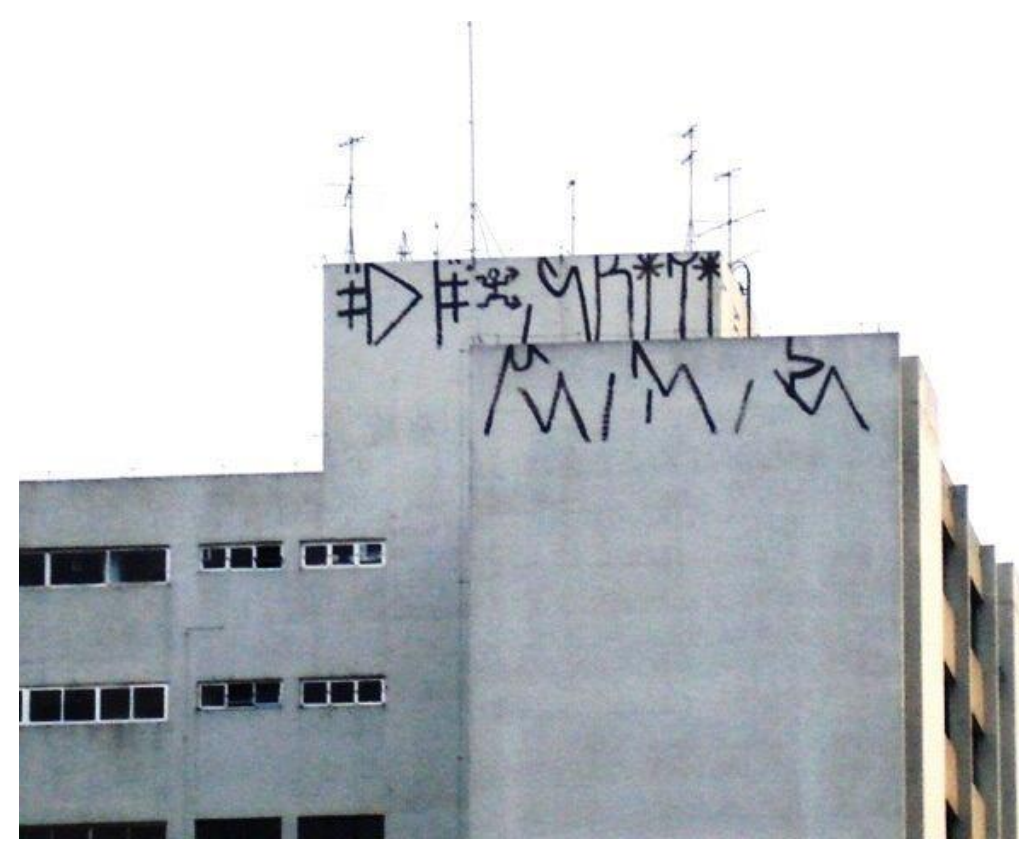

(BESIDE COLORS, 2011) 
Pelo spray de Tchentcho, \#Di\# e Xuim, a pichação consolidou-se como uma prática característica das metrópoles brasileiras no início dos anos 1990. Eles possibilitaram a afirmação da pichação, porque conseguiam imprimir suas marcas em todo lugar, sobretudo em topo de prédios, como o Edifício Itália ou o Conjunto Nacional em São Paulo. Dessa forma, Tchentcho, \#Di\# e Xuim ganhavam destaque, pois se criou uma concorrência entre os sprayers para mostrar quem pichava mais e nos lugares mais inacessíveis, o que incentivava o espalhamento das assinaturas pela cidade.

Essa concorrência não se limitava somente ao spray, pois alguns pichadores integravam gangues (famílias), que possuíam sua marca e não toleravam perder essa competição urbana. Além da exibição de habilidades, a pichação baseia-se em uma atitude de marcação de território. Consequentemente, desrespeitar o território marcado é considerado uma afronta. Por exemplo, cobrir a pichação de alguém ou de um grupo (atropelar) é o tipo de insulto gerador de discórdias, cuja resolução pode ocorrer nos muros ou pessoalmente entre os próprios pichadores.

A partir dessa expansão, as pichações passaram por um processo de aprimoramento tipográfico, em que as assinaturas buscavam ter um traçado mais autêntico, sem sair do gênero pichação, para diferenciar-se das "concorrentes". Conforme o plano da expressão tipográfico ganhava ênfase, mais ininteligível tornavase seu conteúdo para a maioria da recepção pública. Assim, a pichação fechou-se em si mesma e a cidade tornou-se uma folha em branco, na qual os pichadores gravavam suas marcas em função dessa acirrada disputa entre eles. Em decorrência dessa atitude, houve uma exclusão social dessa prática, geralmente associada à criminalidade crime e a valores estéticos negativos. Embora o público, a partir desse momento, tenha rechaçado a pichação, o grafite continuou em um processo gradativo de aceitação social. 
Figura 29 - Pichação em ação

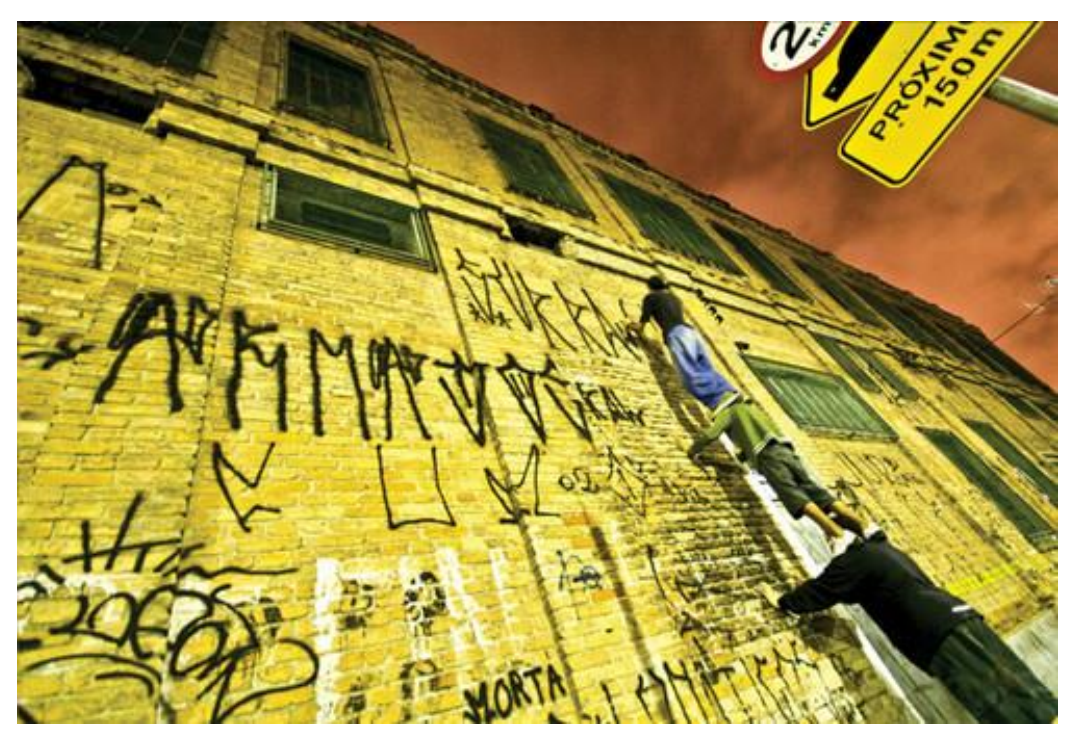

(PIXO, 2009)

É na geração posterior a Alex Vallauri que o grafite brasileiro evoluiu e ganhou maior reconhecimento internacional. Essa visibilidade beneficiou ambas as gerações, pois tanto as obras de OSGEMEOS, quanto as de Rui Amaral passaram a ser apreciadas na virada do século XX.

A produção contemporânea empregava estilos e suportes tão variados que ficou difícil apreender a arte urbana. Na virada de 1980 para 1990, com a inserção do grafite nos museus, já havia uma discussão sobre os limites do movimento, que foi ampliada durante a década de 1990, conforme os artistas buscavam novos meios de expressão dentro do espaço urbano. Com isso, a arte contemporânea abriu um campo ainda maior para as atividades artísticas urbanas, devido à sua menor restrição normativa, em relação aos materiais e à própria prática. O percurso artístico de OSGEMEOS acompanha essa abertura conquistada pela arte urbana. 
Figura 30 - Grafite de OSGEMEOS em São Paulo

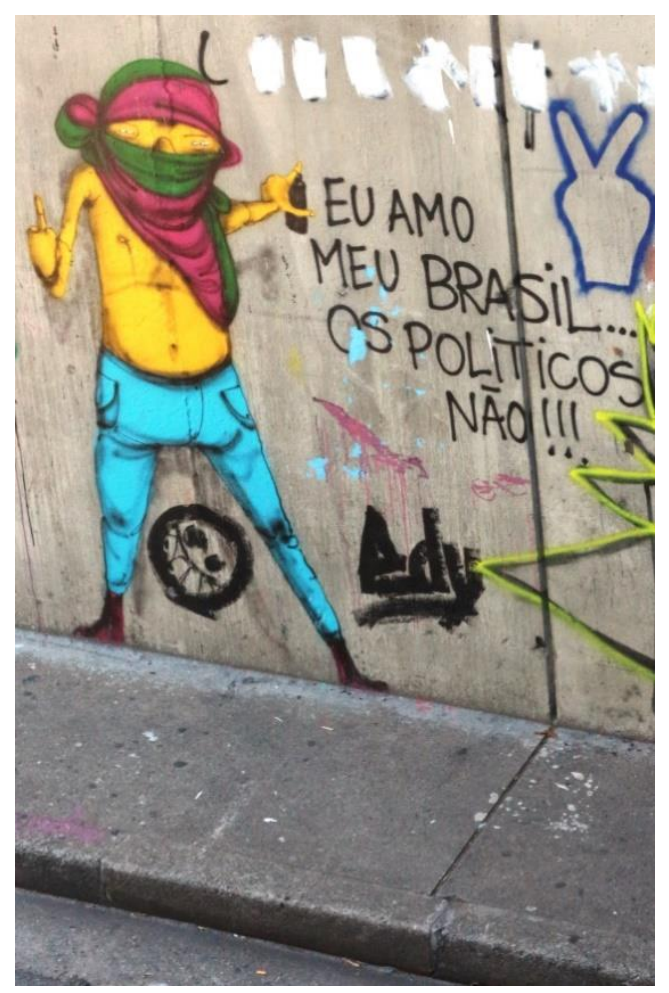

(MAIAN, 2015)

Os irmãos gêmeos Gustavo e Otávio Pandolfo iniciaram suas atividades no grafite marginal, mas foi pelo trabalho de Barry Mgee (Twist) que eles foram estimulados a seguir a atividade profissionalmente. A partir da segunda metade dos anos 1990, seu estilo já estava amadurecido e a linguagem do grafite passou a ser empregada como ferramenta para o desenvolvimento de novos trabalhos. Sem abandonar a prática do grafite, quadros, murais, instalações, esculturas e animações começaram a integrar sua produção, que obteve um gradativo reconhecimento, sobretudo, na década de 2000. Suas obras utilizam personagens característicos, compostos geralmente por membros delgados, cabeça grande, pescoço curto e tonalidade amarelada da pele; que ora integram cenários oníricos, promovendo um discurso distenso, ora estão em situações realistas, gerando uma tensão no discurso.

O prestígio e a heterogeneidade de suas obras podem ser exemplificados pelos grafites encontrados nas ruas de São Paulo, pela pintura realizada na fachada do Tate Modern, pela instalação feita nas ruas de Nova Iorque em parceria com o renomado artista Banksy e também por outra parceria com Nunca e Nina na intervenção que cobriu toda a parte exterior do castelo de Kelburn, na Escócia. 
Nunca possui uma obra mais direcionada ao estilo grafite, porém, adotou o quadro e até mesmo um avião como suporte. Ao iniciar suas atividades na pichação, aos 12 anos, e migrar para o grafite - que o consolidou como um artista contemporâneo - Nunca segue o mesmo percurso de muitos grafiteiros, que são considerados reabilitados socialmente por abandonarem a pichação em prol do grafite. Sua obra é marcada pelo uso de figuras de índios, cuja pele formada por linhas cruzadas valoriza a textura visual.

Figura 31 - Inscrição urbana de Nunca

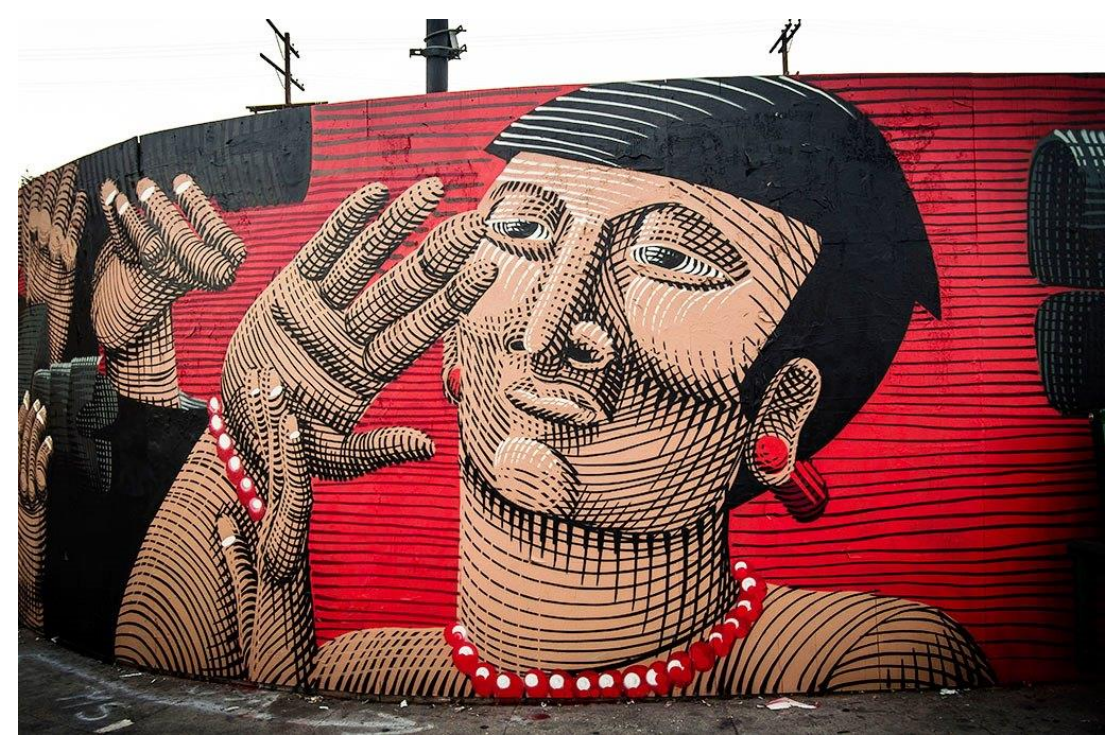

(SLEEPBOY, 2013)

Na esteira de Nunca, destaca-se o artista chamado Cranio por seus índios azuis com faixa vermelha nos olhos, imersos em um cenário surrealista semelhante ao estilo de OSGEMEOS. Um trabalho proeminente do artista foi o grafite feito em um fosso de elevador de 80 metros de altura, cujo tamanho e disposição vertical chama atenção por ser pouco comum no discurso artístico em geral. 
Figura 32 - Inscrição urbana de Cranio na Passagem Literária da Consolação

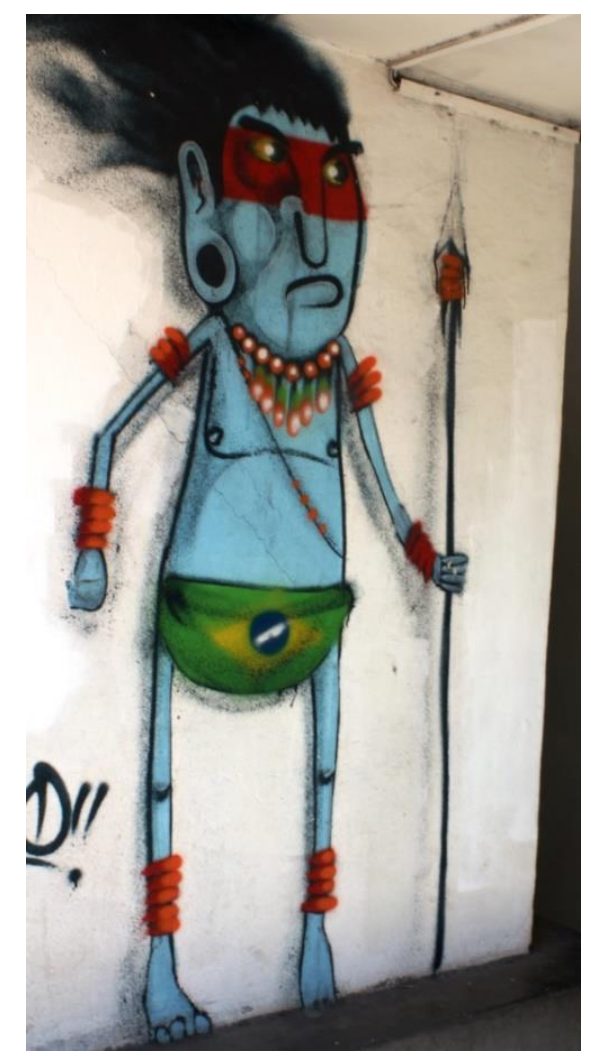

(MAIAN, 2015)

Juntamente a Nunca e a OSGEMEOS, Nina Pandolfo fez parte da intervenção no Castelo de Kelburn e integra a geração de artistas urbanos contemporâneos. Sua carreira começou nas artes plásticas e, semelhante ao que ocorreu na Europa e nos EUA, percebeu no grafite, no início dos anos 1990, um modo de desenvolver seu trabalho, que a reencaminhou posteriormente aos ateliês. As imagens produzidas pela artista possuem uma recorrente temática infantil, inspirada no estilo do mangá e do animê japonês. As personagens femininas com olhos grandes e arredondados são um exemplo dessa referência oriental e o emprego de traços suaves acentua a expressividade de sua temática. Seus trabalhos, reconhecidos por exposições em diversos lugares no mundo, são elaborados em diversos suportes, como esculturas, quadros, objetos e murais; afirmando a tendência de expansão do campo da arte urbana. 
Figura 33 - Obra de Nina Pandolfo

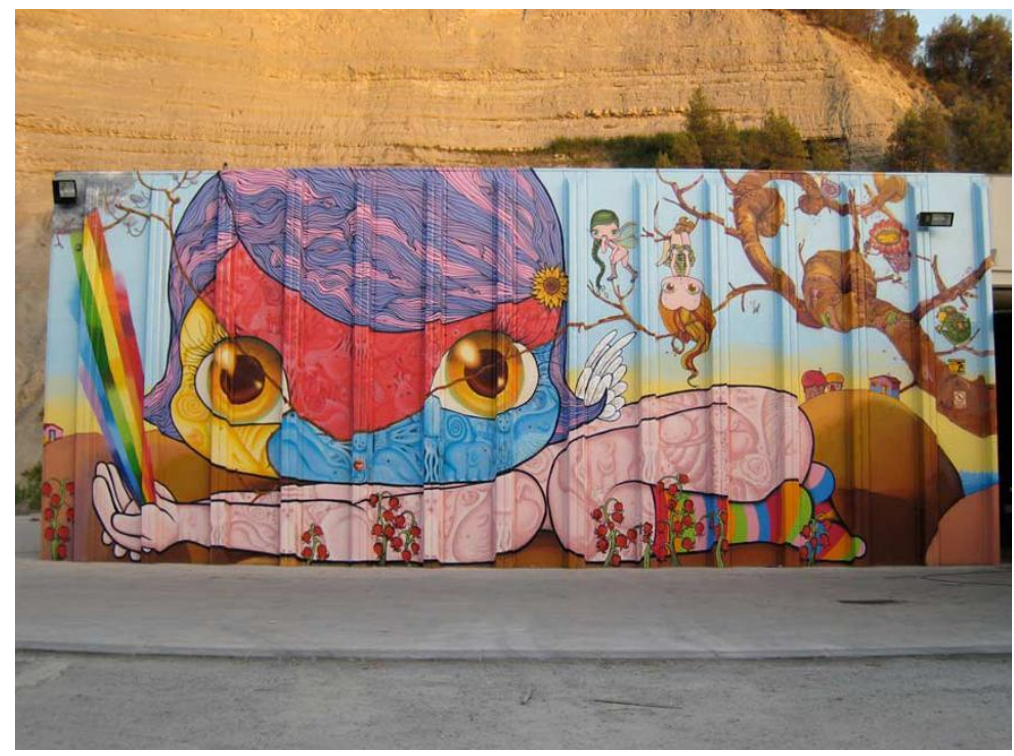

(NINA PANDOLFO, 2016)

É na virada do século XX que esses artistas garantem seu lugar no mercado de arte contemporânea e suas produções passam a não se limitar mais à região. Por isso, a diferenciação entre uma arte urbana brasileira e outra internacional perde relevância a partir de então.

\subsection{Multiplicidade DA ARte urbana}

A expansão das inscrições urbanas gerou uma intensa produção artística em grande parte do mundo e, com a internet, essa produção foi amplamente divulgada. As inscrições urbanas criaram um efeito de democratização da arte, assim, cada pessoa poderia produzir uma obra: bastava sair à rua com um spray e escrever em um muro ou produzir adesivos em casa e espalhá-los pela cidade. Enfim, a interação com a cidade via inscrições urbanas foi ampliada por inúmeras possibilidades de execução, divulgação e conservação, pois após a realização da obra, seu autor pode fotografá-la e postá-la na internet.

Desse modo, houve uma multiplicação da prática que pode ser observada sob duas vertentes. De um lado, essa massa produtora emula formas, técnicas, estilos e 
suportes já estabelecidos por uma "tradição" das inscrições urbanas, criando-se uma repetição homogênea. Por outro lado, observa-se outra vertente que elabora novas formas, reflete sobre sua própria linguagem, dialoga com o cânone artístico e gera uma inovação heterogênea em seu campo, sobressaindo-se por sua singularidade na massa produtora.

Busca-se, então, analisar a vertente mais inovadora, porque foi responsável pela evolução do movimento artístico e pela instauração dos modelos seguidos pela vertente mais homogênea de produção. Dentro dessa heterogeneidade, ainda é constatada uma enorme variedade de obras, pois a contemporaneidade gerou uma extensa massa ligada às inscrições urbanas: muitos artistas destacam-se por meio de suas obras veiculadas na internet e poucos integram o mainstream da arte dita contemporânea.

Faz-se necessária uma triagem dessa variedade, levando a abordagem de artistas integrados ao mercado da arte. Nesse contexto, um artista chama atenção tanto por seu trabalho artístico, quanto pelo modo com que muda sua relação com o mercado de arte: Banksy.

O jovem britânico iniciou sua carreira como sprayer no mundo do grafite "clássico", no entanto, distanciou-se das regras impostas pelos grafiteiros ao adotar o estêncil como sua principal ferramenta. Criou-se uma relação conflituosa entre seu grupo de origem e a evolução de sua carreira artística, principalmente, devido ao uso do estêncil, que está relacionado à falta de habilidade do artista. Contudo o estêncil é considerado uma ferramenta que proporciona maior rapidez de execução e melhor acabamento nos grafites, sobretudo, nas ruas inglesas onde as leis antigrafite são severas. Ainda que tenha se afastado do grafite wild style, Banksy também não seguiu em direção ao mercado de arte contemporânea.

$\mathrm{Na}$ lacuna entre o mundo do grafite selvagem e o sofisticado mundo da arte contemporânea, Banksy inseriu sua produção. Assim, sua obra dialoga intensamente com a história da arte, mas sob uma postura de grafite selvagem. A inserção de seus quadros nas paredes de museus como o Louvre, sem autorização, é um exemplo dessa mistura, pois enquanto o quadro se relaciona criticamente com a tradição artística, a invasão do espaço do museu está ligada à arte de rua. Além do discurso sarcástico de apelo social, à Blek le Rat, Banksy inova também no modo de promoção de sua obra no mercado. 
Figura 34 - Banksy em releitura da obra Des glaneuses de Jean François Millet

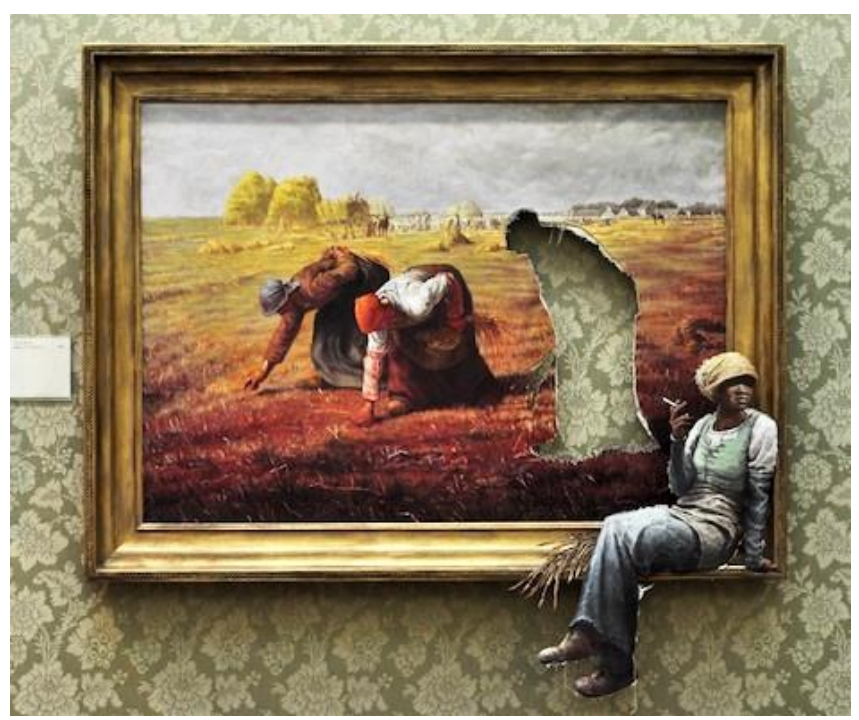

(BANKSY, 2014)

Com exposições próprias e com a utilização da internet como meio de divulgação e venda, Banksy estabeleceu um mercado próprio para suas obras, sem depender de mecenas, colecionadores, galerias, enfim, do circuito do mercado de arte. $\mathrm{O}$ artista subverteu as instituições, ora realizando suas exposições em lugares alternativos, como fábricas abandonadas, ora apropriando-se do museu com total liberdade, sem a interferência de curadores ou diretores. Banksy não criou somente um grupo de compradores em um mercado alternativo, mas um grupo de fãs que o acompanha fielmente. No entanto essa autonomia não impede o ingresso de suas produções no mercado de arte tradicional.

Apesar de criar esse mercado paralelo, as obras do artista são muito bem cotadas nos mercados de arte tradicionais. Por isso, não é raro que suas obras feitas ilegalmente nas ruas, como inscrições em muros, sejam adquiridas por importantes casas de leilão, como a Sotheby's. A obra é comprada do dono do muro, que é cortado e transportado para as galerias e casas de leilão. Mesmo assim; Banksy é inserido no mercado de arte sem passar pelo processo comum do artista contemporâneo: começando em galerias, passando por museus e por fim chegando às casas de leilão.

Outros artistas igualmente alcançaram prestígio pela singularidade de suas obras, como Shepard Fairey, famoso pela criação do cartaz de Obama na campanha à presidência dos EUA e por seu ícone Obey, cartaz do rosto de um lutador mexicano com a célebre sentença em inglês, obedeça. 
Figura 35 - Cartaz da Campanha de Barack Obama e Obey de Shepard Fairey

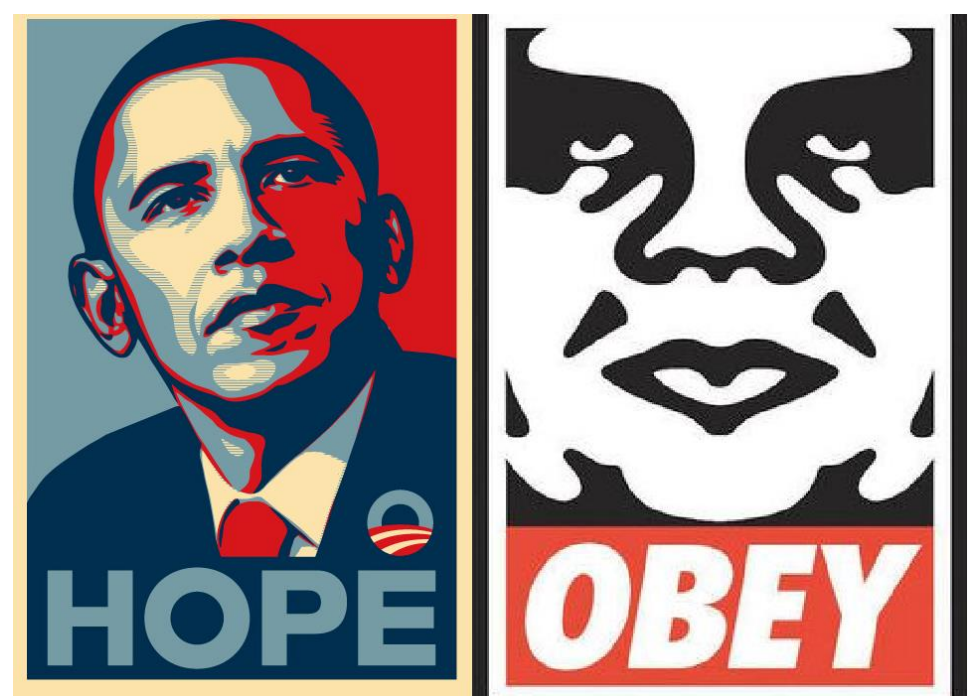

(FAIREY, 1995)

Ou ainda o artista francês Invader, que utiliza um ícone dos videogames dos anos de 1980, Space invaders, para explorar sua repetição em diversos lugares no mundo. Inicialmente feito em azulejo, o trabalho de Invader ampliou sua temática e suporte, contando com o emprego de diversos personagens e produzindo esculturas e pinturas. Por meio de seu site, o artista atualiza as informações sobre suas intervenções, que atualmente contam com 3.323 obras em 65 cidades ao redor do mundo (INVADER, 2014). Com isso, ele propicia um jogo de "caça ao tesouro" aos seus enunciatários, que buscam imagens desses pequenos alienígenas ocultados no espaço múltiplo das cidades.

Figura 36 - Invaders (Rua Peixoto Gomide, São Paulo)

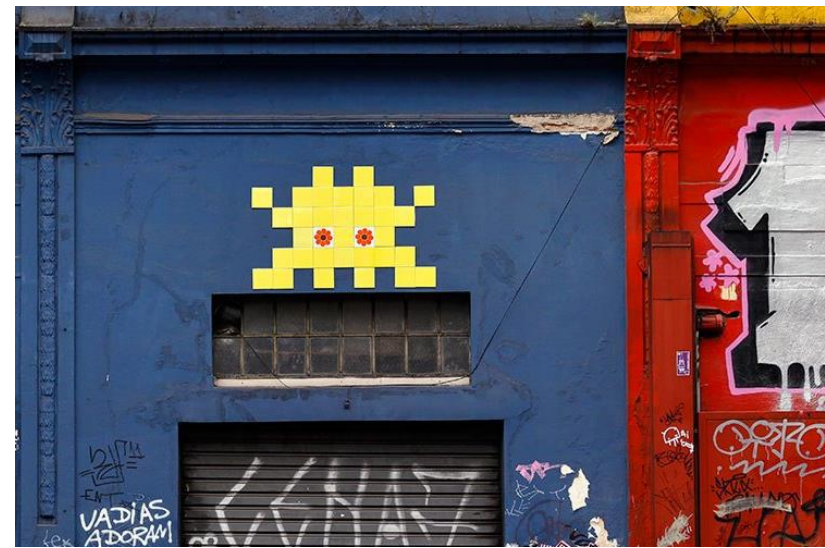

(CORREA, 2016) 
No Brasil, Kobra é um inscritor que segue esse estilo ligado à tradição deixada por Blek le Rat, ao usar imagens de figuras célebres, mas singulariza a inscrição pelo uso de um fundo geométrico e colorido em contraste com a figura realista em preto e branco. Além desse estilo marcante em sua obra, o artista chamou atenção inicialmente por seu projeto Muros da memória, que reproduz fotos de época das cidades onde as inscrições são realizadas.

Figura 37 - Kobra retrata Tom Zé (bairro Vila Madalena em São Paulo)

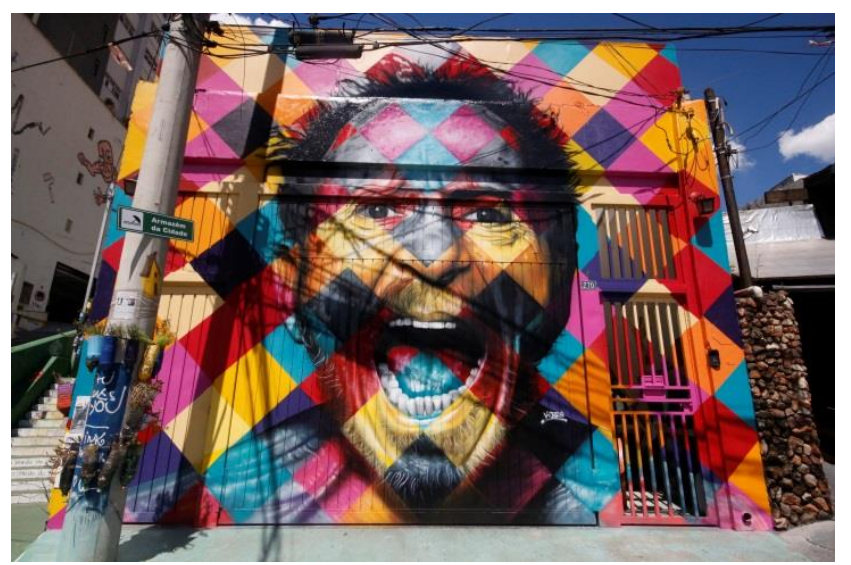

(CORREA, 2016)

Merece igual destaque a produção de arte urbana abstrata. Artistas que fazem um grande aprofundamento tipográfico alcançando resultados abstratos, como também aqueles que já partem de um ponto de vista puramente formal. Dois exemplos dessa vertente são observados no grafite geométrico-abstrato do polonês Seikon e nas formas orgânicas escondidas nos esgotos de São Paulo da obra de Zezão, cujo Leitmotiv seria a palavra vício.

Figura 38 - Inscrição de Seikon

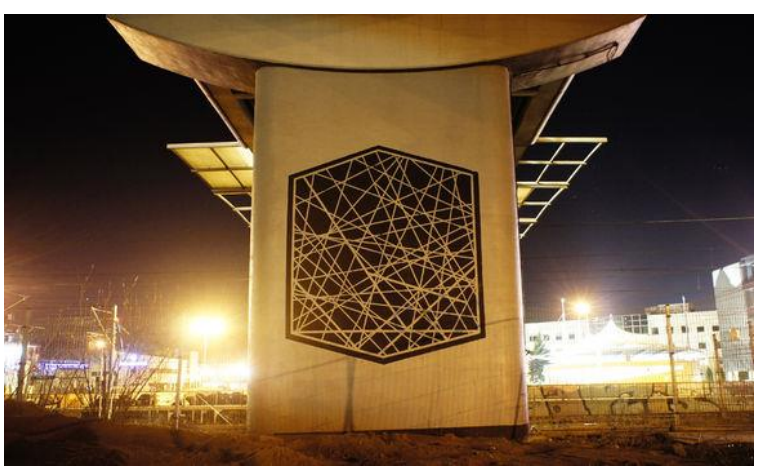

(FATCAP, 2011) 
Figura 39 - Obra de Zezão

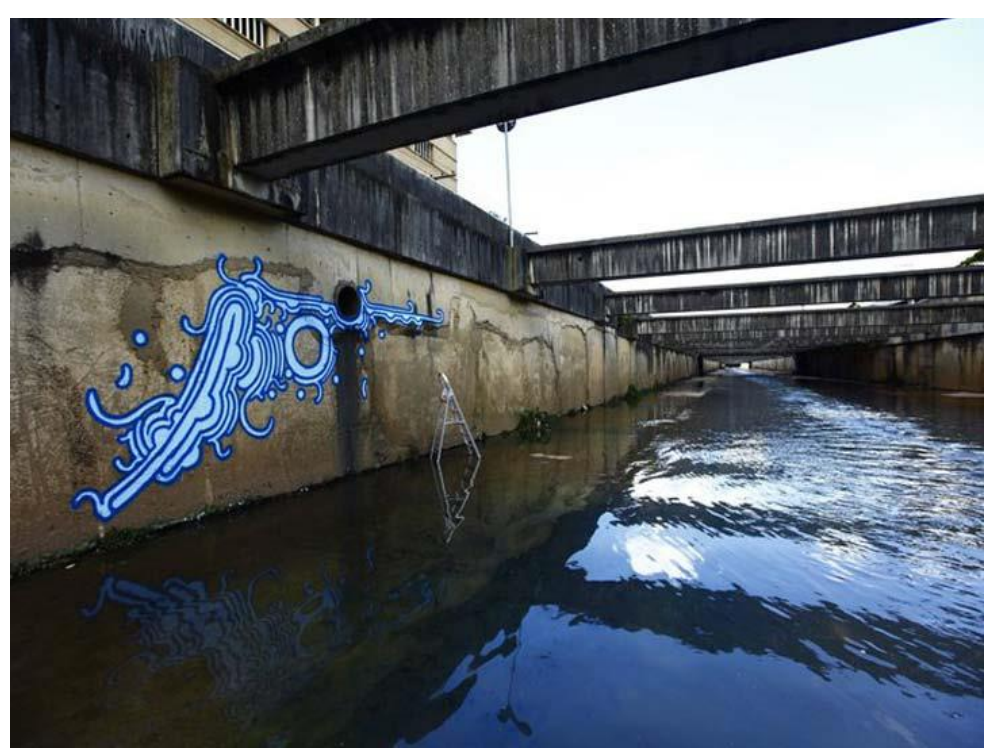

(ZEZÃO, 2012)

Observa-se, então, uma característica comum a todos esses artistas urbanos: a profunda integração do uso do espaço, do suporte e da obra pictural, já que a multiplicidade de seus trabalhos possibilita o trânsito entre o público e o privado e entre o autorizado e o proibido. Um ponto alto dessa integração entre espaço e obra é a vertente do Grafite 3D, cujo uso da técnica de trompe-œil cria outros espaços dentro da cidade.

Figura 40 - The Caves obra de Edgar Mueller

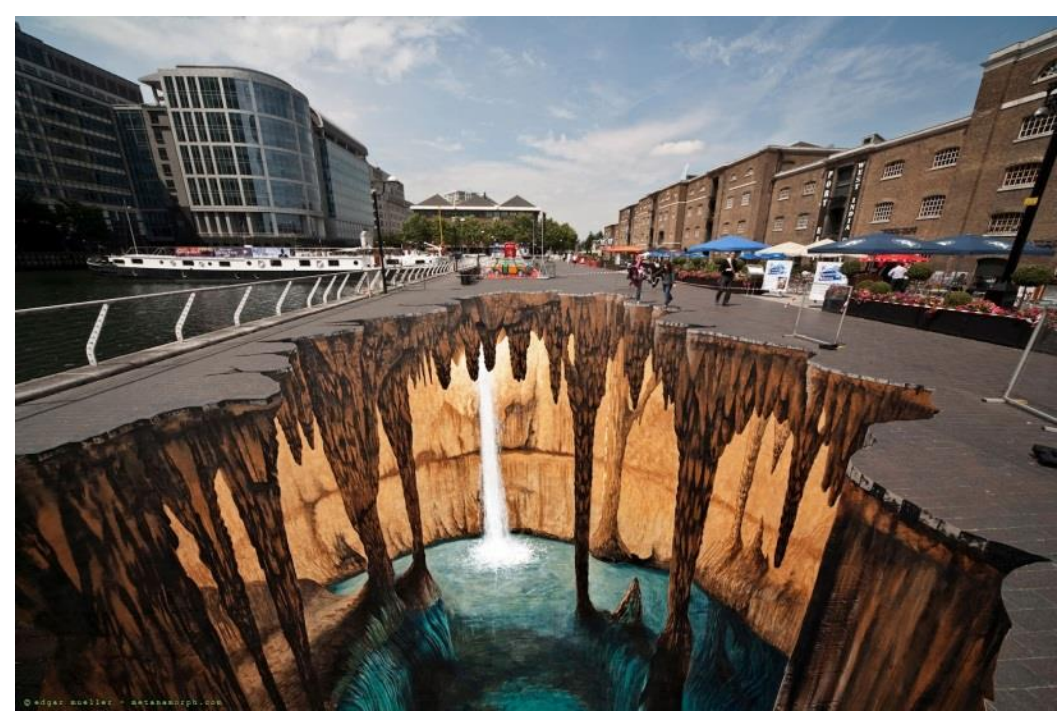

(MUELLER, 2011) 
Ao longo da história das inscrições urbanas, verifica-se que a linguagem pictórica vai tomando o lugar da linguagem verbal, ou seja, a palavra cede lugar à imagem. Obras de apelo social, como no Maio de 1968, ainda permanecem, mas transmitem seus conteúdos pelo plano da expressão plástico. Banksy é um exemplo desse uso, que intensifica ambos os planos da linguagem para conseguir maior impacto enunciativo.

Figura 41 - Obra política de Banksy

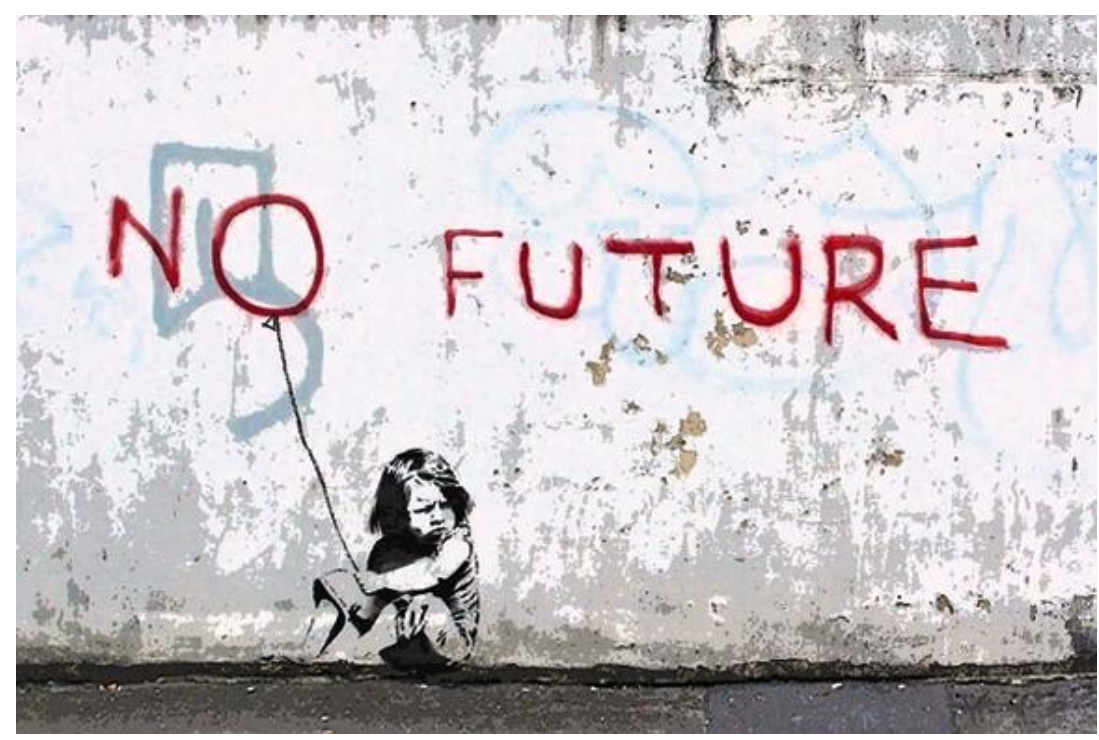

(BANKSY, 2014)

Por outro lado, a pichação parte da linguagem verbal para esvaziar seu conteúdo verbal e trabalhar com a estética tipográfica. Portanto, a ênfase no plano do conteúdo verbal representada pelo movimento de Paris e a valorização do plano da expressão plástico encontrada no grafite de Nova Iorque servem como parâmetros para a observação das inúmeras modalidades de inscrições urbanas, que mesmo inovando, ainda estão atreladas a esses núcleos estruturais.

Desse modo, torna-se pertinente compreender como essa prática social, que interfere no desenvolvimento formal das inscrições urbanas, pode ser analisada à luz da teoria da linguagem. A condução das premissas teóricas encontra na semiótica francesa uma linha de pesquisa pertinente, mas outras áreas são trazidas para a reflexão, pois contribuem na elaboração do modelo de análise. 


\section{NORMAS E VALORES}

Pixar é errado Errar é humano Somos humanos, por isso pixamos Anônimo (ou Grilo 13) 
Feito o percurso histórico das inscrições urbanas, segue-se para a investigação do desenvolvimento da arte urbana a partir dos estudos linguísticos e sociais. Tomamse os conceitos de norma linguística (COSERIU, 1979), de normas e valores (MERTON, 1970) e de endogênese e exogênese (KLINKENBERG, 2008, 2010) pela abordagem que fazem dos mecanismos de manutenção linguística ou social e a possibilidade de sua transgressão. Nessa relação dinâmica entre a norma estabelecida e sua inovação, geradora de uma nova norma, seria possível obter um modelo para aplicá-lo no campo das artes plásticas. Propõe-se integrar essa base teórica linguística ao campo da semiótica tensiva, criando uma ferramenta de análise para o desenvolvimento das inscrições urbanas.

Com base na famosa dicotomia de Saussure langue/parole, Eugenio Coseriu (1979) propõe um acréscimo de outra categoria para tratar das relações da língua quanto sistema, sem excluir a realização na fala. Essa categoria foi denominada norma. Coseriu discute os equívocos das interpretações acerca das lições deixadas pelo mestre genebrino, principalmente, sobre o estudo exclusivo da langue em detrimento da parole. Para ele, é pela fala (parole) que é possível realizar as abstrações linguísticas necessárias para que se atinjam as funções do sistema. Desse modo, o sistema, diluído pelas escolhas individuais e pelas coerções sociais, já é encontrado na fala e o objetivo do linguista é triar os elementos funcionais presentes na fala para chegar ao sistema. Entretanto dividir a língua entre sistema e fala parece-lhe insuficiente, porque são excluídas as repetições não funcionais geradas pelos falantes, já que tais repetições guiam o ato verbal (BÜHLER, 1950, apud COSERIU,1979, p. 72).

$\mathrm{O}$ linguista romeno vê no sistema um conjunto de possibilidades funcionais, no qual o falante seleciona o material para a realização de seu ato de fala. Essa seleção procura referência nas práticas linguísticas cristalizadas socialmente, cuja funcionalidade sede lugar ao uso, à recorrência, às escolhas partilhadas pelos falantes, enfim, à norma. O autor demonstra em vários níveis (fonológico, morfológico, lexical, sintático etc.) seu ponto de vista. Assim, é escolhido um exemplo relativo ao nível fonológico para ilustrar o pensamento coseriano.

Analisam-se três variações do fonema $/ \mathrm{r} / \mathrm{em}$ língua portuguesa (SILVA, 2011), utilizando como exemplo a palavra /porta/, que varia em relação à região do falante. De acordo com as representações do Alfabeto Fonético Internacional (2003), observa-se: 
Tabela 1 - Variações do fonema / $r /$ no PB

\begin{tabular}{|c|c|}
\hline Região & /Porta/ \\
\hline $\begin{array}{c}{[r]} \\
\text { Região Metropolitana de São } \\
\text { Paulo }\end{array}$ & ['por ta] \\
\hline $\begin{array}{c}{[\mathrm{x}]} \\
\text { Rio de Janeiro }\end{array}$ & ['pox ta] \\
\hline $\begin{array}{c}{[-\cdot]} \\
\text { Interior do Estado de São Paulo } \\
\text { e Periferia da cidade São Paulo }\end{array}$ & ['pox ta] \\
\hline
\end{tabular}

Mesmo com a variação do fonema $/ \mathrm{r} /$, não há alteração no significado da palavra. Se uma pessoa da região metropolitana de São Paulo, com o uso da alveolar [r], outra pessoa do Rio de Janeiro, com o uso da velar [x]; e uma terceira pessoa do interior de São Paulo, com o uso do retroflexo [卂] conversassem empregando a palavra "porta", não haveria nenhuma incompreensão por parte dos falantes, ou seja, cada variante regional não altera o significado da palavra, apenas muda sua expressão fonológica ${ }^{14}$. O uso de cada falante foi normatizado em três sons distintos, contudo, isso não afeta o sistema, já que o termo "porta" mantém a função do $/ \mathrm{r} / \mathrm{sem}$ alteração de significado.

Por isso, só há diferenciação no sistema se houver uma comutação: uma mudança tanto no plano da expressão, quanto no plano do conteúdo do signo. De acordo com a noção saussuriana de valor (um signo é o que os outros não são), não é possível que três sons se relacionem a um mesmo significado, pois sua funcionalidade estaria perdida ${ }^{15}$. Logo, os "erres" são manifestações normatizadas por um grupo social e, ao abstraí-los de seu uso, chegaríamos a uma função /r/ no sistema. Contrariamente, em /carro/ e /caro/, ['cahu] e ['caru], a troca do fonema /r/ gera uma mudança de conteúdo em cada variação, formando dois signos pela comutação.

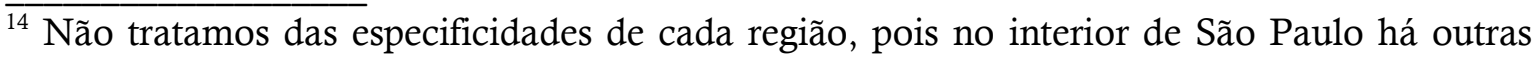
formas de uso do $/ \mathrm{r} /$, além da retroflexa, cujo aparecimento incide também na periferia da região metropolitana de São Paulo (ver OUSHIRO, 2015).

${ }^{15}$ Desconsidera-se o conceito de sincretismo nesse caso, pois as variantes ainda permanecem irrelevantes para o sistema, que só admite como função o próprio sincretismo.
} 
Portanto, esses fonemas são distintivos no sistema, têm sua função específica, sem ligação com a região do falante.

O que, na verdade, se impõe ao indivíduo, limitando sua liberdade expressiva e comprimindo as possibilidades oferecidas pelo sistema dentro do marco fixado pelas realizações tradicionais, é a norma. A norma é, com efeito, um sistema de realizações obrigadas, de imposições sociais e culturais, e varia segundo a comunidade (COSERIU, 1979, p. 74).

Nesse sentido, justifica-se a presença de uma terceira categoria que intermedeie a dicotomia saussuriana língua/fala: a norma. Por um lado, ela é uma abstração da realização da fala, é mais sistemática por suas reiterações e, por outro lado, possui menos pertinência funcional que o sistema. Ela sistematiza o falar e concretiza o sistema.

A norma coseriana é dividida em dois tipos: norma individual e norma social. Entendida como repetição, tornam-se simples os conceitos mencionados, pois a norma individual nada mais é que o "elemento constante na fala do indivíduo, eliminando-se apenas o que é puramente ocasional e momentâneo" (1979, p. 73) e a norma social é constituída pela reiteração de elementos em um grupo social. A diferença entre elas está em seu número de falantes, em um ou mais de um.

Essa divisão quantitativa inaugura uma reflexão sobre as normas na linguística saussuriana, que chega até as recentes propostas do linguista belga Jean-Marie Klinkenberg $(2008,2010)$. Na promoção de uma alternativa para as discussões sobre normas objetivas e normas avaliativas, Klinkenberg vai buscar na sociologia de R. K. Merton (1970) e nas propostas de Manessy (1992) as bases para o desenvolvimento de uma visão integradora do fenômeno normativo.

Segundo o sociólogo estadunidense, normas existem em função de valores e é na comparação entre ambos que são formados comportamentos de determinados grupos sociais. Assim, o valor é entendido como "objetivos culturalmente definidos, de propósitos e interesses, mantidos como objetivos legítimos para todos, ou para membros diversamente localizados da sociedade" e a norma "define, regula e controla os modos aceitáveis de alcançar esses objetivos" (MERTON, 1970, p. 205). A partir 
das relações entre normas e valores, são descritas cinco formas de adaptações sociais: a conformidade, a ritualização, a inovação, a retirada e a rebelião ${ }^{16}$.

A conformidade define-se pelo equilíbrio entre normas e valores, ou seja, as normas sociais são uma extensão de seus valores. A ritualização acata as normas em detrimento dos valores, assim, no desequilíbrio entre normas e valores, as normas são privilegiadas e, inversamente à ritualização, a inovação promove os valores em detrimento das normas, criando mudanças e formando novas normas. Já a retirada e a rebelião não partilham das normas e valores vigentes, mas enquanto a retirada abandona totalmente normas e valores, a rebelião propõe sua substituição por novas normas e novos valores. É possível aproximar a rebelião da inovação e a retirada da ritualização, já que estes tendem à conservação e aqueles à transgressão.

A partir desse quadro teórico, Klinkenberg (2008, 2010), apoiado no conceito de norma endógena de Manessy (1992), elabora seu modelo normativo, cuja característica é a aplicação de uma dimensão espacial nas relações entre normas e valores. Assim, em um grupo A, as normas produzidas e/ou seguidas internamente por esse grupo, em função de seus valores, constituiriam as normas endógenas, enquanto as normas provindas de outros grupos sociais, acatadas ou aceitas pelo grupo A, formariam as normas exógenas.

Para Klinkenberg $(2008,2010)$, não é somente o número de pessoas que cria as categorias normativas (individual e social), mas também a adequação entre regras e valores. A recorrência de determinado uso (COSERIU, 1979) pode acontecer tanto na formação das normas exógenas, quanto na formação das normas endógenas, porém, um quadro mais dinâmico é produzido quando se analisa a relação do falante com essas recorrências, adotando-as ou rechaçando-as na comparação com seus valores. É nessa comparação que o sujeito ou o grupo promove a manutenção ou a inovação das normas. Em uma relação hierárquica, na qual "as normas são a expressão de princípios que determinam aquilo que é ou não desejável. Esses princípios são os

\footnotetext{
$\overline{{ }^{16} \mathrm{O} \text { termo em inglês }}$ retreatism foi considerado como retraimento na tradução de Miguel Maillet (MERTON, 1970), no entanto, segue-se com a tradução "retirada" sugerida pela professora Dra. Elizabeth Harkot-de-La-Taille no exame de qualificação dessa tese. Assim como o termo ritualism é traduzido por ritualização conforme a tese de livre-docência de Harkot-de-La-Taille (2013).
} 
valores" (KLINKENBERG, 2008, p. 8, tradução própria), coloca-se o valor em um nível superior ao da norma ${ }^{17}$.

Klinkenberg (2010) exemplifica essa relação pela literatura em língua francesa considerada periférica. Enquanto há uma visão universal de língua francesa para os falantes da França, nos outros países francófonos essa ilusão de uniformidade linguística não é tão consolidada devido a suas particularidades sociais e regionais. Para maioria dos franceses a norma é estabilizada, no entanto, para os falantes de outros países, as mesmas normas não satisfazem suas exigências. Por conta disso, realiza-se uma descompensação entre a norma francesa e os valores de determinada região francófona fora da França, gerando-se uma adequação interna denominada endogênese. Essa relação pode ocorrer desde a adoção total das normas exógenas, passando por uma compensação parcial, até a sua substituição completa, o que cria uma tensão entre as modalidades deônticas e volitivas, produtoras da conservação e das mudanças linguísticas, discursivas e sociais em determinado grupo.

[A norma endógena] não é um conjunto de regras ou de convenções explicitáveis, o que implicaria no reconhecimento, pelo menos implícito, de uma normatividade, mas uma normalidade fundada no desejo recíproco de comunicar, um acordo implícito quanto à adequação dos modos de expressão e um saber cultural partilhado ${ }^{18}$ (MANESSY, 1992, p. 55, tradução própria, grifo nosso).

O autor segue sua exposição atribuindo um fenômeno de implicitação e explicitação das normas. Assim, em um eixo, em que cada extremo representa um grau máximo de implicitação e de explicitação normativa, ao passar de um polo ao outro teríamos seus respectivos matizes, ou seja, da ocultação das normas à sua padronização na língua. Portanto, a formação das normas ocorre em duas etapas sobrepostas: de um lado ela é gerada em relação aos valores, de outro, ela possui graus de exposição no grupo social. A princípio, parece haver uma relação de dependência entre essas etapas (HJELMSLEV, 1971, p. 42-43), pois o grau de explicitação interfere na relação entre normas e valores e vice-versa, ou seja, as duas etapas são uma constante para a formação da norma.

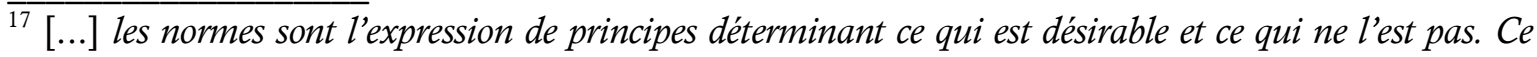
sont ces principes que l'on appelera valeurs.

${ }^{18}$ Ce n'est pas un ensemble de règles ou de conventions explicitables, ce qui impliquerait la reconnaissance au moins implicite d'une normativité, mais une normalité fondée sur le désir réciproque de communiquer, un accord implicite quant à l'adéquation des modes d'expression et un savoir culturel partagé.
} 
Por exemplo, nos jogos da Copa do Mundo de 2014, o hino nacional de cada seleção em campo era executado parcialmente, seguindo uma norma elaborada pela FIFA (que é a representante das confederações de futebol de cada país participante da Copa), porém, nos jogos da seleção brasileira, houve a criação de uma nova norma: quando o hino nacional brasileiro era interrompido (segundo o protocolo da FIFA), os torcedores continuavam cantando o hino à capela até o término de sua primeira parte. Com base na torcida brasileira, torcedores de outros países passaram a repetir a mesma conduta em jogos de suas respectivas seleções.

A criação dessa norma endógena deu-se tanto pela inadequação dos valores dos torcedores em relação ao protocolo da FIFA, quanto pela imposição dessa norma exógena (grau máximo de explicitação) e, a adoção dos outros grupos da norma criada pela torcida brasileira, deu-se também pela explicitação da prática, televisionada para todo o mundo. Logo, a formação das normas endógenas possuiria uma interdependência da relação norma vs. valor com o grau de explicitação normativa.

O modelo de endogênese e exogênese surge como uma tentativa de conciliar normas objetivas e avaliativas, pois aquelas são constituídas pelas constantes observadas em um fenômeno e estas pela legitimação de dado uso por um grupo; de um lado, a recorrência; de outro, a aceitação e a prescrição (KLINKENBERG, 2008, p. 2). Para a descrição dessas normas, há modelos cujos pontos de vista criam objetos distintos. A norma objetiva adota a justaposição e a norma avaliativa a articulação:

\begin{abstract}
A justaposição consiste em descrever cada norma de modo autônomo, como um sistema independente. Isso pôde ser feito para algumas normas técnicas ou para as normas dialetais. A vantagem da solução é que se pode eliminar da descrição os artefatos sociais, geográficos, estilísticos e contextuais, ou pelo menos neutralizá-los, e a partir disso tratar autenticamente cada norma como um dado objetivo. Os inconvenientes estão na própria neutralização e na eliminação de toda perspectiva comparatista: o choque entre normas ou a sua dinâmica estão destinados a escapar totalmente na descrição ${ }^{19}$ (KLINKENBERG, 2008, p. 14).
\end{abstract}

\footnotetext{
${ }^{19}$ La juxtaposition consiste à décrire chaque norme de façon autonome, comme un système indépendant. Ce qui a pu être fait pour quelques normes techniques, ou pour les normes dialectales. L'avantage de la solution est qu'on peut éliminer de la description les artefacts sociaux, géographiques, stylistiques et contextuels, ou tout au moins les neutraliser, et dès lors traiter authentiquement cette norme comme un donné objectif. Les inconvénients sont cette neutralisation elle-même, et l'évacuation de toute perspective
} 
Esse ponto de vista centraliza os resultados e tende a valorizar a recorrência, a quantificação, enquanto a valorização da qualidade, da percepção da norma, é desempenhada pela articulação, que:

[...] consiste em ordenar todas as normas segundo um esquema comum no qual elas se inscrevem em uma ordem de abstração e esquematização crescente. Nesse ponto, pode-se reconhecer o modelo proposto por Hjelmslev. Este último busca uma arborescência dominada por uma norma geral que dá conta das realizações mais abstratas do esquema [linguístico], e na qual se dividem as normas particulares - topoletais, socioletais, tecnoletais -, que são ainda atualizações da norma geral. A vantagem é que nesse caso todos os fatos da língua são levados em consideração, inclusive aqueles que uma linguística mais rigorosa tenderia a rejeitar a domínios marginais e à imprecisão (como a "estilística"). O inconveniente é que o parcelamento das normas faz com que tudo, definitivamente, seja norma. E, em consequência disso, não é possível perceber as fronteiras entre fatos erráticos e produções normatizadas ${ }^{20}$ (KLINKENBERG, 2008, p. 14, tradução própria).

Apesar de abordar a norma por seu caráter reiterativo, abarcando uma descrição por justaposição, a norma klinkenberguiana estabelece-se principalmente em uma visão avaliativa, guiada por uma metodologia de articulação. No entanto, como o próprio autor diz, sua proposta revela mais uma tensão entre essas duas perspectivas e menos um modelo definitivo.

Sob o viés de sua proposta, é possível reestruturar a tipologia de Merton (1970) e pensar em um processo de mudanças e estabilizações normativas. Tal possibilidade não foi concretizada, mas se o linguista belga buscou as bases para suas formulações na obra do sociólogo estadunidense, parece pertinente adequar essa tipologia social às normas endógenas e exógenas.

comparatiste : le choc entre normes, ou la dynamique des normes, sont voués à échapper totalement à la description.

${ }^{20}$ [L'articulation] consiste à ordonner toutes les normes dans un schéma commun, où elles s'inscrivent dans un ordre d'abstraction et de schématisation croissant. C'est là, on s'en souviendra, le modèle proposé par Hjelmslev. Celui-ci envisage une arborescence dominée par une norme générale, rendant compte des réalisations les plus abstraites du schéma, et où se répartissent des normes particulières - topolectales, sociolectales, technolectales — qui sont autant d'actualisations de la norme générale. L'avantage est ici qu'on prend en compte tous les faits de langue, y compris ceux qu'une linguistique soucieuse d'ordre avait tendance à rejeter vers des domaines marginaux et au statut flou (comme la "stylistique "). L'inconvénient est que la parcellarisation des normes fait que tout, en définitive, est norme. Et on est par conséquent impuissant à percevoir les frontières entre faits erratiques et productions normées. 


\subsection{DISCUSSÃO SOBRE AS NORMAS}

Embora a relação entre normas e valores tenha sido retirada da sociologia de R. K. Merton (1970), Klinkenberg (2008, 2010) adota parcialmente essa tipologia social, pois somente os conceitos de ritualização e inovação entram no modelo de endogênese e exogênese. Assim, os outros tipos sociais serão considerados para estabelecer uma comparação entre as estruturas normativas.

Como descrita anteriormente, a tipologia apresenta um movimento de maior ou menor presença de normas e valores na formação de determinado tipo social, mas ao pensar nos três tipos desconsiderados por Klinkenberg (2008, 2010), rebelião, retirada e conformidade; observa-se uma possível inadequação em ambas as propostas. Rebelião e retirada propõem uma mudança tanto de valores, quanto de normas, o que faz pensar em dois tipos de valores e normas: norma vigente e norma inovadora, valor vigente e valor inovador. Antes de aceitar essa duplicação, verifica-se que as escolhas de Klinkenberg $(2008,2010)$ parecem simplificar os processos.

Considerando somente a inovação, a ritualização e a conformidade na formação dos tipos sociais de Merton, a rebelião e a retirada poderiam ser vistas como um recrudescimento da inovação e da conformidade, pois se o valor corresponde aos objetivos sociais de determinado grupo ou indivíduo e as normas estabelecem um modo de alcance desses objetivos, a rebelião seria caracterizada pela falta de representação normativa e seu objetivo seria mudar essas normas para que elas estejam conformes aos seus valores ao invés de uma total anulação de normas e valores. Já a retirada estabeleceria uma conformidade entre valores e normas, inadequados à prática social vigente, cujo efeito de sentido seria seu abandono. A inadequação representada pela rebelião e retirada não está nos valores, mas, sim, nas normas.

Desse modo, sob o viés das normas endógenas e exógenas (KLINKENBERG, 2008, 2010), os valores da rebelião estariam em desacordo com as normas exógenas e esse tipo social promoveria a criação de normas endógenas que substituiriam as normas exógenas. Do mesmo modo, os valores da retirada excluiriam as normas exógenas e seriam instituídas normas endógenas em conformidade com novos valores. A diferença entre os dois tipos sociais estaria na direção tomada para dentro ou para 
fora de um padrão social, pois enquanto a rebelião visa a ser a norma vigente, igualmente àquela que foi substituída, a retirada cria suas próprias regras em um mundo à parte, sem pretensões de tornar-se um modelo.

Além da rebelião e da retirada, a conformidade é outro tipo desconsiderado pelo linguista belga. A exclusão da rebelião é facilmente entendida se ela for considerada uma inovação assim como a retirada, mas ambas estariam ligadas à conformidade. Pelo desenvolvimento da investigação, a conformidade seria mais pertinente para explicar esses dois tipos sociais, pois a inovação teria como fim a conformidade. Ressalta-se que Klinkenberg estabeleceu um modelo sobre o desvio e, portanto, a conformidade não teria lugar destacado, entretanto, ao definir as normas endógenas como "o uso corrente admitido como corrente" (KLINKENBERG, 2008, p. 3), sua validade, ainda assim, teria relevância.

Com isso, as normas endógenas ganham maior pertinência por conciliar os dois métodos de descrição, um uso corrente (norma objetiva) tomado como corrente (norma avaliativa). Além disso, a endogênese promove a inovação das normas em relação aos valores e fixa um equilíbrio entre eles, já que ela surge da instabilidade entre normas e valores para efetivar-se na formação de novas normas, por causa da urgência dos valores. Essa adequação conduziria à conformidade. Vistas desse modo, as normas endógenas seriam o resultado de um processo cujos constituintes seriam a inovação e a conformidade.

Já a ritualização estaria ligada às normas, pois os valores do grupo seriam controlados ou abafados para evitar o "desconforto" inicial que toda inadequação traz, ou seja, na tensão entre normas e valores, as primeiras sobrepõem-se às segundas. De todas as formas, nota-se a ausência de uma visão estática desses processos normativos, até mesmo a conformidade seria entendida como um momento de estabilidade tênue.

Essa tensão é gerada também pela maior dinamicidade dos valores em relação às normas, que tendem a ser modalizadas pelo dever e precisam manter certa estabilidade para a promoção de sua recursividade, ao passo que os valores tendem a adequar-se às modalidades volitivas, mais instáveis, e não precisam ater-se 
obrigatoriamente a nenhuma norma específica ${ }^{21}$. Logo, considera-se que o regime dos valores repercute no regime normativo por meio de um aumento no grau de sua intensidade. Segundo a proposta a seguir, ritualização, inovação e conformidade pertenceriam a níveis do processo de formação das normas endógenas e exógenas.

Nesses termos, a conformidade, relativa às normas endógenas, ocultaria uma tensão interna entre contínua mudança de valores e estabilidade normativa. Isso ocorreria dentro de uma faixa de controle, quer dizer, as normas não estariam conformes a todos os valores, mas, sim, aos que estruturassem a identidade do grupo social ou da variação linguística por sua alta intensidade, cuja autenticação seria dada pelo grau de recursividade. A partir do momento que houvesse um aumento no conjunto de valores fixados fora dessa faixa de controle, seria detectada uma anomalia, cuja inadequação aumentaria pela repetição da norma, ocasionando maior desgaste na sua capacidade identitária. Duas possibilidades seriam previstas nessa situação: a autorregulação, por meio de uma inovação, ou a compensação normativa, geradora da ritualização. No primeiro caso, retorna-se à fase inicial de conformidade, no segundo, um aumento de intensidade das normas impediria a expansão desses novos valores até o ponto de serem seguidas por inércia, prescrição ou imposição, criando uma conformidade instável.

Uma gradação é observada em cada fase descrita, mais ou menos exprimiriam as quantidades necessárias para a formação das fases. Da conformidade para a inovação é necessário um aumento nos valores consolidados fora do regime normativo, da conformidade para a ritualização, um aumento nas normas concomitante a uma diminuição nos valores; da ritualização para a inovação, é necessária uma retomada nos valores. Aumentos e diminuições mostram o jogo de tensões característico das relações entre normas exógenas e endógenas, para isso, é necessário recorrer à teoria que reflita apropriadamente sobre essas formulações.

É a semiótica tensiva, cuja maior reflexão se encontra na obra de Claude Zilberberg, que fornecerá os parâmetros para o desenvolvimento de um modelo normativo, pelo qual serão estudadas as conservações e mudanças ocorridas na história das inscrições urbanas. A formulação de uma estrutura normativa não está

\footnotetext{
${ }^{21}$ Lembrando que o estudo das normas trata das inscrições urbanas, originadas na segunda metade do século XX. Em outros períodos históricos as relações entre normas e valores talvez sejam diferentes.
} 
bem definida nos textos de Merton (1970) e Klinkenberg (2008, 2010), principalmente, no que se refere ao conceito de valor. Ambos os autores concentraram-se em delinear as relações entre os termos, sem aprofundar suas características processuais, contudo, suas propostas deixam balizas para o desenvolvimento dessas estruturas. Nessa perspectiva, os estudos sobre valor e processos tensivos de significação ganham pertinência.

\subsection{VALOR}

O conceito utilizado na sociologia não tem abrangência metodológica, se for transposto estritamente para a teoria da significação. Embora Klinkenberg (2008, 2010) o utilize inicialmente tal qual está na obra de Merton, parece que ao longo de seus textos o conceito é tomado mais como princípio, assim, dos objetivos sociais almejados pelo grupo, fica a ideia de direção, cujo conteúdo se aproxima da teoria da linguagem.

Esse sentido, intrínseco a todo valor, pode ser estruturado anteriormente aos juízos sociais. Os mecanismos de formação do valor são produtores da rede de valor social, ou seja, há um esquema anterior ao uso. A moralização é resultado dessa estrutura e não o contrário, pois o bom, o belo e o justo são respostas ao sistema de valores estabelecido internamente. Dessa forma, o modelo recebe um caráter mais abstrato, pois visa chegar às funções do sistema.

Fontanille e Zilberberg (2001) propõem que o valor seja uma função constituída por dois funtivos $^{22}$ - as valências -, cujas dimensões, extensidade e intensidade, estão relacionadas respectivamente ao inteligível e ao sensível. Cada dimensão é formada por subdimensões, temporalidade e espacialidade, na dimensão extensiva e, andamento e tonicidade, na dimensão intensiva; que, por sua vez, são formadas por operadores tensivos. Várias possibilidades operativas decorrem da intersecção dessas subdimensões, por exemplo, breve/longo, na temporalidade; aberto

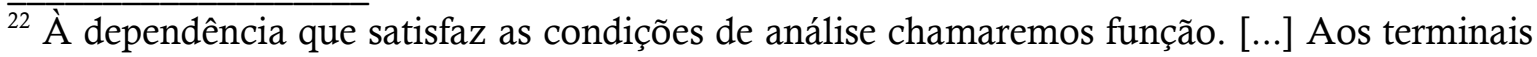
de uma função chamaremos funtivos, entendendo por funtivo um objeto que estabelece função com outros objetos (Hjelmslev, 1971, p.55).
} 
e fechado, na espacialidade; tônico e átono, na tonicidade e rapidez e lentidão, no andamento. Pensando em cada dimensão sob a forma de vários pontos que integram um eixo gradativo, no qual suas extremidades apontam direções operativas (subdimensões), o valor é produzido na junção de um ponto extensivo com um ponto intensivo. Essas relações geram não somente um modelo para a criação do valor, mas também para uma rede de categorias como a ubiquidade, o acontecimento, a profundidade e o ritmo (ZILBERBERG, 2010, p. 4).

Dentro dessa perspectiva, os regimes participativo e exclusivo destacam-se na elaboração da estrutura tensiva do valor, pois estabelecem conjunções, "e... e", ou disjunções, "ou... ou", entre as valências. $\mathrm{Na}$ conjunção, as valências são convergentes, menos pede cada vez menos e mais pede cada vez mais, e na disjunção, elas possuem uma relação inversa, menos pede mais e mais pede menos. A partir dos dois regimes, as operações triagem e mistura, situadas no eixo extenso, ligam-se à intensidade formando valores de absoluto e valores de universo.

Não é difícil compreender os conceitos mencionados, visto que a denominação terminológica parece definir-se claramente. O regime de triagem é determinado por seu caráter selecionador, ou seja, aquilo que se reduz rumo à unidade pertence a esse regime. Como no exemplo bíblico que deu origem ao ditado "separar o joio do trigo". Nessa parábola, Jesus pede aos ceifeiros uma triagem "Ajuntai primeiro o joio e atai-o em feixes para queimá-lo, mas recolhei o trigo no meu celeiro" (BÍBLIA. MATEUS, 13: 24-30). Para que o trigo seja estocado, é necessário triar a erva do cereal. O regime de mistura, inverso ao de triagem, mescla os valores rumo à pluralidade. Como no famoso discurso de Martin Luther King Jr "Eu tenho um sonho de que um dia, nas rubras colinas da Geórgia, os filhos de antigos escravos e os filhos de antigos donos de escravos possam se sentar juntos à mesa como irmãos" (LUTHER KING JR., 1963, p. 4 , tradução própria) ${ }^{23}$. Nesse discurso, o ativista estadunidense almeja a convivência inter-racial pacífica, ou seja, a mistura sem conflitos entre as raças.

Cada regime possui graus de intensidade, tônico ou átono. Em um regime de mistura, a intensidade baixa (átona) formaria valores da diversidade e a intensidade alta (tônica) resultaria na universalidade, por sua vez, a triagem átona seria relacionada a valores da totalidade, ao passo que a triagem tônica levaria à unidade

\footnotetext{
${ }^{23}$ I have a dream that one day on the red hills of Georgia, the sons of former slaves and the sons of former slave owners will be able to sit down together at the table of brotherhood.
} 
(FONTANILLE e ZILBERBERG, 2001, p. 33). Em uma representação gráfica pelo plano cartesiano, a triagem e a mistura estariam situadas no eixo das abscissas (extensidade), enquanto que suas respectivas intensidades estariam no eixo das ordenadas.

Esquema 1 - Gráfico Tensivo

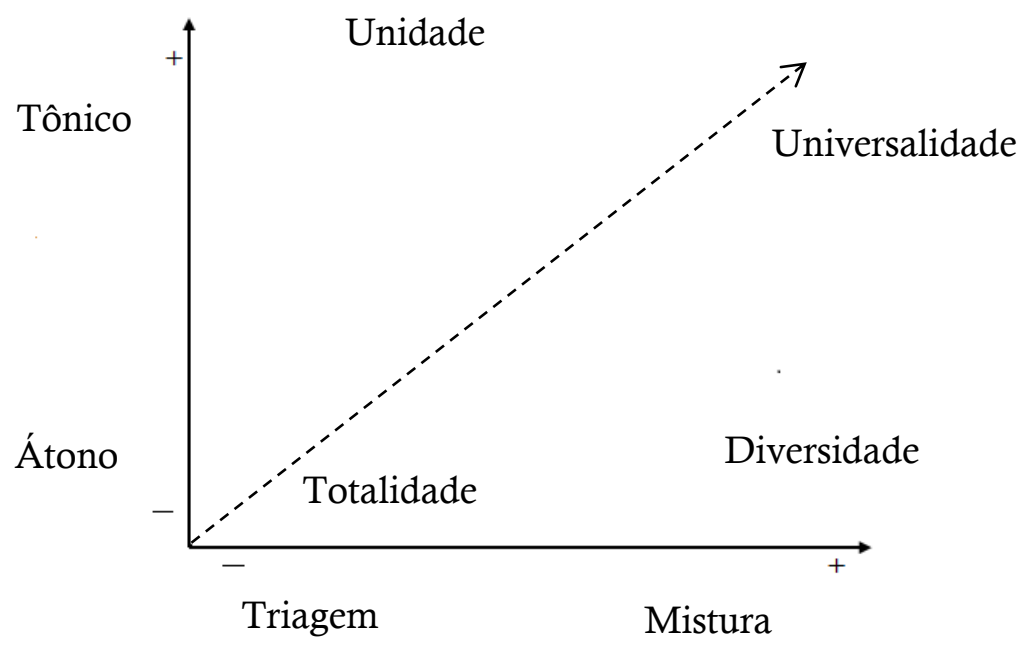

Estabelecidas as primeiras bases tensivas, buscam-se os valores relacionados às inscrições urbanas. A história das inscrições urbanas descrita no capítulo 1 fornece os elementos necessários para explorar a constituição desses valores através da aplicação do modelo tensivo.

\subsection{VALORES NAS INSCRIÇÕES URBANAS}

O entendimento sobre os desenvolvimentos das inscrições urbanas, com suas inúmeras variações, começa pelo estabelecimento de seus valores, que são o alicerce das relações normativas. Antes de chegar aos processos endógenos e exógenos, é preciso saber quais valores estão em jogo na comparação com as normas vigentes, com isso, é possível explicar a evolução do objeto artístico. 
A origem das inscrições urbanas estabelece os moldes para os percursos realizados ao longo de sua história. Propõe-se que os valores encontrados na formação das inscrições urbanas seriam mantidos ao longo de sua história e pela tensão produzida na relação com as normas, surgiria cada variação estilística. Dessa forma, a constante-valor seria um elemento estrutural que daria uma identidade global às modalidades locais. A essa identidade global deu-se o nome de inscrição urbana.

Paris e Nova Iorque representariam as duas vertentes de sua origem, cujas diferenças estariam nas ênfases dadas a cada plano da linguagem. Enquanto as inscrições de Paris valorizariam mais o plano do conteúdo verbal, as de Nova Iorque dariam maior relevância ao plano da expressão visual ${ }^{24}$.

Mesmo em contextos diferentes, verifica-se que tanto as inscrições do Maio de 1968, quanto às tags dos guetos nova-iorquinos são caracterizadas pela difusão artística no espaço público. O desejo de reconhecimento parece modalizar as ações dos inscritores urbanos que, pela repetição e apropriação do espaço público e privado, disseminam seus objetos pela cidade. A intensidade dessa expansividade pode ser medida por sua repressão e o caso de Nova Iorque representa bem essa situação, pois as adequações do grafite aos diferentes suportes deram-se por conta da intensa repressão da prefeitura daquela cidade. Dos metrôs aos muros, o grafite foi encontrando os espaços necessários para sua difusão, que cresceu em intensidade e em diversidade de suporte, na medida em que leis antigrafite se tornavam cada vez mais duras.

A expansão tônica, modalizada pelo querer, seria o modo inicial de alcançar os valores, mas não é o valor em si. Como foi descrito na história das inscrições urbanas, a difusão excessiva conduziu a uma mudança da prática rumo à concentração. A inserção das inscrições urbanas no mercado de arte resultou dessa transformação. Essa estratégia de divulgação que é alterada ao longo do tempo ora pela difusão, ora pela concentração, seria um modo de alcançar um reconhecimento por parte do enunciatário. $\mathrm{O}$ valor de identidade seria a constante propulsora das conservações e inovações ocorridas na história das inscrições urbanas.

No entanto esse valor identitário nas inscrições urbanas seria definido como reconhecimento, pois "o desejo de alcançar um grande renome é algo compartilhado

\footnotetext{
${ }^{24}$ A relevância dada para cada plano nessas duas vertentes das inscrições urbanas será desenvolvida no capítulo posterior.
} 
por todos inscritores, a fama é considerada seu objeto último" (CASTLEMAN, 2012, p. 112 , tradução própria $)^{25}$ :

[O grafite e a pichação em sua evolução] traziam uma mensagem implícita de rupturas políticas a serem empreendidas. A seguir, eles se tornaram grafites de desvio: nos cartazes publicitários, eles aparecem como sinais de contestação de sonhos, de denúncia de ilusões. Nos dias de hoje, as pichações pretendem não ter referências nem valor artístico. São hieróglifos urbanos que pretendem que outros saibam que eles existem. Eles expressam um pedido de reconhecimento e incidem prioritariamente nos equipamentos de transporte, de polícia e de formação. Os limites da cidade são, assim, redefinidos, e o espaço público, privatizado. $\mathrm{Na}$ falta de poder integrar-se, um novo espaço urbano é redefinido em seu proveito (GREFFE, 2013, p. 282).

Em termos narrativos, o reconhecimento, dado pelo enunciatário (que pode ser tanto o passante sem a devida competência para compreender a prática, quanto os pares inscritores) à performance do enunciador-sujeito, seria sancionado pelo destinador social, positivamente, conforme esse enunciador-sujeito atinja a maior fama possível, e negativamente, se ele continuasse no anonimato ${ }^{26}$.

Nota-se que a construção do objeto não é suficiente para conseguir uma sanção positiva, a identificação dessa performance do enunciador-sujeito é crucial. Além disso, esse reconhecimento é pautado pela quantidade, quanto maior alcance ele tiver, mais positiva é a sanção. Assim, a narrativa entre um enunciador-sujeito que espalha suas inscrições pela cidade para ser identificado por um maior número de pessoas e ser reconhecido é infindável, posto que outros enunciadores-anti-sujeitos concorrem pelo mesmo objetivo ${ }^{27}$.

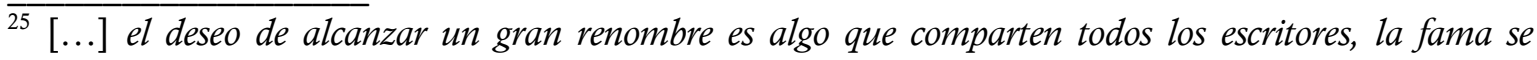
considera el último de los objetivos.

${ }^{26}$ Esse reconhecimento social não pertence somente à prática das inscrições urbanas. Não seria descabido dizer que a pressão social pelo sucesso, consequentemente pelo reconhecimento, faz parte dos discursos sociais cotidianos, como também foi identificada na sociedade estadunidense descrita por Merton (1970).

${ }^{27}$ Embora Barros (2002) coloque a enunciação em termos narrativos para tratar do narrador textual, acredita-se que essa abordagem seja válida para a cena enunciativa no caso das inscrições urbanas: "só é possível pensar em actantes do discurso se uma perspectiva narratológica for adotada no exame da enunciação, ou seja, se a enunciação for abordada do ponto de vista de sua organização narrativa ou espetacular" (p. 80).
} 
Uma relação entre o enunciador e enunciatário é formada, em que o primeiro (inscritor) faz um papel de destinador e o segundo (o leitor), de destinatário ${ }^{28}$. Para que o sujeito-enunciador seja sancionado positivamente em um programa narrativo de base, ele deve estabelecer outra narrativa, neste caso como destinador. Na perspectiva do enunciatário, o enunciador seria um destinador, pois ele o manipularia por intermédio de seu texto. Esse novo programa narrativo de uso poderia ser mais bem entendido sob a perspectiva da formação de identidade produzida na relação sujeito e texto cultural.

Harkot-de-La-Taille (2013) propõe tal formulação com base nas propostas de Ricoeur (2005), que são apresentadas brevemente a seguir para se compreender a relação entre destinatário-sujeito e texto cultural.

Para Ricoeur (2005), a formação identitária constitui-se de três elementos, idem, ipse e alter. Os dois primeiros elementos integram o universo interior do sujeito, caracterizados por um fator constante e outro variável. O idem é a instância buscada pelo sujeito para obter uma estabilidade identitária, uma constante que o mantém reconhecível ao longo de sua vida. O ipse é o elemento da instabilidade, pois insere o sujeito nas vicissitudes do momento histórico e no imprevisível que o ato de estar no mundo produz. Esses dois traços internos ao sujeito estão em constante tensão: o sujeito está constantemente atualizando a segurança do idem em função das mudanças circunstanciais do ipse. Nessa dialética, o alter, elemento externo ao sujeito, entra para trazer maior dinâmica à relação dual entre o idem e ipse. Ele introduz o reconhecimento mútuo, integrando a identidade da pessoa que "para se reconhecer, carece do reconhecimento de si pelo outro" (HARKOT-DE- LA-TAILLE, 2013, p. 35-36).

Retomando, em poucas palavras, o interesse de Ricoeur recai sobre o conceito de identidade da pessoa capaz, concebido como resultante da tensão dialética entre uma parte imutável, conservadora do mesmo, e uma parte flexível, definidora do modo de colocação de si no momento histórico, ambas formando um conjunto sujeito à alteridade e dela dependente para o reconhecimento de si. O tempo participa da identidade, sendo o passado aliado ao idem, pela

\footnotetext{
${ }^{28}$ Ainda seguindo a proposta de Barros (2002) sobre a "narrativização" da cena enunciativa: "[...] o enunciador coloca-se como destinador-manipulador, responsável pelos valores do discurso e capaz de levar o enunciatário, seu destinatário, a crer e a fazer" (p. 92).
} 
memória, e o futuro ao ipse, pela promessa (HARKOT-DE- LATAILLE, 2013, p. 38).

Estabelecidas as instâncias formadoras da identidade, chega-se à influência exercida pelo texto cultural nesse universo do sujeito. A absorção da significação de um texto pelo sujeito seria entendida por meio da inserção de traços de alter em idem, mas isso só ocorreria em função do aval dado pelo ipse.

O cotejo dos conceitos de processo de significação, na semiótica francesa, e de pessoa capaz, em Ricoeur, elucida sua comunicabilidade: para a primeira, o processo de significação decorre de uma tensão dialógica entre um destinatário-sujeito, munido de seu repertório de vida, e um texto cultural (verbal, visual, auditivo, multimodal etc); para o segundo, a pessoa capaz se constrói na tensão dialética com a alteridade, por ação do ipse, que poderá vir a incorporar sua identidade. Se a resultante de tal tensão integrar sua memória, passará a fazer parte de seu mundo, de seu repertório significante, como valor, informação, conhecimento, crença, afeto, sentimento etc. É possível tecer um paralelo da relação que ocorre entre idem e alter com a que tem lugar entre destinatário-sujeito e um texto cultural. O ipse seria a instância a vir fazer sentido daquilo que o alter, por exemplo o texto cultural, propõe ao destinatário-sujeito, a instância que, em face dos efeitos de sentido construídos, torna alguns desses sentidos seus e os integra à identidade da pessoa (HARKOTDE- LA-TAILLE, 2013, p. 39).

Quando um grafite passa a constituir o universo sensível e inteligível do sujeito, integrando sua memória, uma parte de seu sentido (alter) é agregada a identidade do sujeito (idem e ipse).

Essa incorporação dos sentidos textuais para o mundo do sujeito seria um reconhecimento de que aquele texto cultural significa para o sujeito e quanto mais pessoas aderirem ao texto, maior seria seu reconhecimento social. Voltando à narrativa de uso, o destinador-enunciador ao produzir um texto cultural, uma inscrição urbana, seria bem-sucedido em sua manipulação, se o destinatário-leitor tomasse o texto cultural como alter e o incorporasse ao seu universo de valores. Em um conjunto de destinatários-leitores, o acúmulo dessas incorporações, do alter para o idem, formaria a fama ou o reconhecimento almejado na narrativa de base.

Assim, o valor regente nas inscrições urbanas seria o reconhecimento, o alter. Ao atingi-lo, esse sujeito-enunciador teria a sanção positiva do destinador social nessa narrativa de base. Entretanto vale ressaltar que o enunciador, que sincretiza o papel 
actancial de sujeito e destinador em duas narrativas complementares, também passa pelo mesmo processo de formação de identidade. Enquanto destinador, ele produz o texto cultural que será o alter para o leitor-destinatário, mas enquanto sujeito, os discursos produzidos pelo então leitor-destinatário tornam-se o alter da identidade desse sujeito-enunciador. $\mathrm{O}$ reconhecimento mútuo atinge os dois lados da comunicação.

Além disso, quando se diz reconhecimento não se define sua foria, ou seja, a incorporação de um texto cultural pode ser tomada como negativa ou positiva, pois a formação identitária é múltipla e dinâmica, quer dizer, as avaliações do destinatáriosujeito sobre aquele objeto cultural podem mudar ao longo do tempo.

Para esclarecer essa proposta plena de terminologia semiótica, tomam-se as inscrições de Banksy em uma narrativa baseada na bibliografia sobre o artista, mas não deve ser tomado como um fato biográfico. O exemplo foi criado para ilustrar as relações entre o idem, ipse e alter em uma perspectiva narrativa.

Banksy visa a obter o reconhecimento social por conta de seu trabalho de arte, pois no universo das inscrições urbanas, para se tornar um king é necessário ser reconhecido. Além disso, o sucesso já é um elemento crucial para a sociedade em si, nas inscrições urbanas, esses discursos só são dirigidos à produção artística. Para conseguir alcançar um status de destaque, Banksy produziu uma obra relevante, porque manteve os princípios de transgressão do grafite, misturou-os com um modelo da arte acadêmica e os associou a uma temática política com um tom satírico. As polêmicas causadas por suas obras revelam que elas foram incorporadas ao universo de valores das pessoas, que aprovaram ou reprovaram seu trabalho. Esse impacto foi tão forte que os admiradores das inscrições de Banksy são considerados como fãs. Banksy tornou-se um rockstar e isso deu autonomia para que ele não dependesse do sistema do mercado de arte.

Banksy realizou sua performance e foi sancionado positivamente pela sociedade, ele alcançou um alto grau de reconhecimento, não somente para o grupo de inscritores, mas também para o público geral. Suas obras foram aderidas por essas pessoas, ou seja, como destinador, Banksy produz textos culturais que integram a subjetividade dos destinatários. Ao mesmo tempo, sua identidade enunciativa ou sua imagem é construída pelos discursos de seus fãs, detratores, críticos etc. que anteriormente tinham nas obras de Banksy um alter a ser incorporado. Após esse 
processo, os destinatários vão produzir discursos e textos que constituirão o alter para a identidade desse enunciador.

Propõe-se, então, o valor reconhecimento como condutor da prática das inscrições urbanas. Esse getting up (fazer-se ver) já faz parte da linguagem dos inscritores, pois, evidentemente, se trata de seu objetivo social. No português do Brasil, esse reconhecimento é colocado pelo termo ibope, ou seja, a fama do inscritor é traduzida pelo seu nível de ibope.

Verifica-se que os valores que dão origem às inscrições urbanas são concentradores, porque a multiplicidade de sua produção levaria a uma única identidade, tônica. O reconhecimento é deferido ao único, por isso o conflito gerado pela competição entre os inscritores: muitos querem, alguns fazem e poucos conseguem (ser reconhecidos). Em oposição a essa concentração identitária, existe um movimento normativo de expansão tônica ou átona, por exemplo, por parte das autoridades reguladoras do espaço público, que buscam uma homogeneização desse espaço. As normas tendem a ser universais, pois devem ser respeitadas por todos. $\mathrm{E}$ a expansão átona das normas seria caracterizada pela ritualização, o hábito mecanizado é seguido pela inércia, sem haver uma obrigatoriedade intensa.

Moldadas por esse conflito entre uma individualização dos valores, estabelecidas em um regime exclusivo, contra uma expansão das normas, dirigidas por um regime participativo ou exclusivo, as escolhas enunciativas do grupo formador do movimento das inscrições urbanas definiriam seus percursos de conjunção e disjunção com as normas ao longo de sua história.

Esquema 2 - Formação do valor das inscrições urbanas

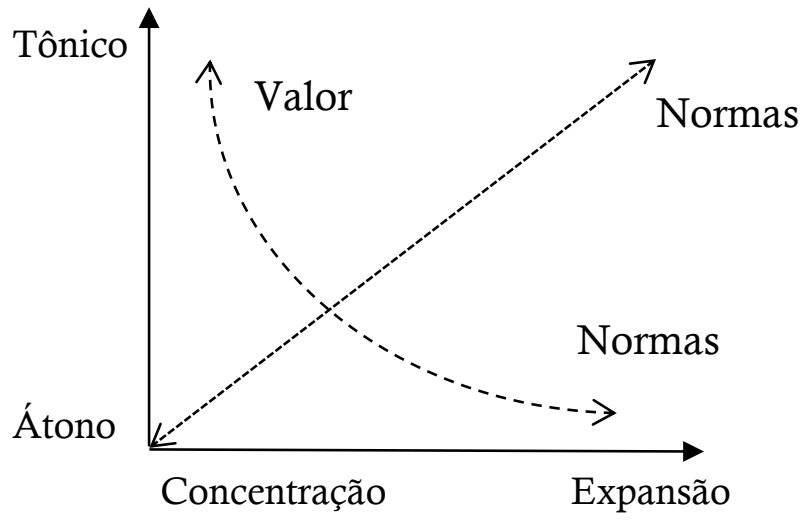


Ao entrar em choque com as normas vigentes, a concentração dos valores promovida pelas inscrições urbanas é mantida. Então, um modelo de normas endógenas e exógenas associado ao modelo tensivo coloca-se a fim de mostrar como se estruturam as resoluções decorrentes dessa tensão.

\subsection{NORMAS PARA AS INSCRIÇÕES URBANAS}

$\mathrm{Na}$ história das inscrições urbanas, dois tipos de normas, ligadas ao valor reconhecimento, parecem estruturar a produção das diferentes modalidades. De um lado, as normas sociais, de outro, as normas artísticas, estas incidem mais sobre o enunciado, aquelas incidem mais sobre a enunciação. Contudo essa separação não delimita totalmente esses dois campos, pois a enunciação interfere no enunciado e vice-versa, do mesmo modo que as normas sociais afetam as normas artísticas e viceversa. Por exemplo, a repressão ao grafite realizado no metrô de Nova Iorque, nos anos de 1980, provocou mudança de suporte e, consequentemente, mudanças plásticas das obras, já que nos muros, o artista tinha mais tempo, mais espaço e mais iluminação para criar e desenvolver suas técnicas e seu estilo. Em contrapartida, a expansão do grafite proporcionou maior discussão sobre arte pública, sobre os espaços institucionais da arte, sobre o espaço público e privado, questionando os valores estabelecidos pela história da arte e a organização visual da cidade.

As normas sociais estariam definidas pela expansão, rumo à homogeneidade, em relação à ocupação e à visualidade do espaço público, ao passo que as inscrições urbanas se dirigiriam à heterogeneidade visual e à concentração do valor. Um caso exemplar de normas sociais é a lei Cidade Limpa (SÃO PAULO, 2006), que regulamentou a comunicação visual na cidade de São Paulo. Suas deliberações associam-se a um dever para todos e a uma uniformização, como abolição de propagandas externas, diminuição do tamanho dos anúncios indicativos das fachadas dos estabelecimentos comerciais e sua padronização.

A nova lei trouxe várias mudanças positivas. A inovação de maior impacto foi a proibição de anúncios publicitários nos lotes urbanos 
como muros, coberturas e laterais de edifícios, além de publicidade em carros, ônibus, motos, bicicletas, etc.

Outras novidades foram a padronização, a simplificação e a redução dos anúncios indicativos, peças que seguirão normas relativas à testada de seus imóveis (SÃ̃ PAULO, 2006).

A reação da intervenção urbana a essa lei pode ser vista no documentário "Cidade Cinza" (CIDADE CINZA, 2013), que mostra o conflito dos artistas urbanos com as empresas de limpeza, contratadas pela prefeitura de São Paulo para manter as determinações da lei Cidade Limpa. O apagamento e a reelaboração de um mural, feito na Avenida 23 de Maio por Nina, Nunca e OSGEMEOS tematiza esse embate entre o poder público e o movimento artístico. Assim, as normas sociais seriam formadas pela conjunção das medidas tomadas pelo poder público e da veiculação midiática sobre as inscrições urbanas.

As normas artísticas seriam definidas pelo mercado de arte, constituído por museus, galerias, colecionadores, casas de leilão e críticos, cujos valores estariam relacionados à singularidade. Essa tendência à originalidade pressupõe um diálogo com a história da arte, seja pelas técnicas, pelos conteúdos ou por sua negação. Noutros termos:

Os valores presentes na avaliação da obra, da notoriedade do artista e da aceitação da obra são do mundo da singularidade. É aquilo que a obra e o artista têm de especial, de original e de único para marcar a diferença, que em parte lhes confere o estatuto necessário para entrar no mercado artístico. É através do reconhecimento de singularidade que o artista adquire notoriedade e reputação e é através da sua reputação que adquire uma posição no mercado artístico (ALMEIDA, 2009, p. 10).

Em entrevista a Angélica de Moraes, a renomada galerista brasileira Luisa Strina, ao responder a pergunta "como você definiria um bom artista?" confirma em certa medida esse valor pela singularidade, pelo único, que vai pautar suas escolhas de trabalho. Em sua resposta:

[um bom artista] é aquele que me perturba, me instiga, que me conta algo que não sei. É aquele que me mostra uma beleza escondida, que me conta um segredo, que me faz pensar. Às vezes essa percepção nasce do impacto de uma obra, às vezes do convívio continuado. Pode ser algo que demoro para entender (MORAES, 2014, p. 214). 
Mesmo que cumpridas essas exigências, o mercado restringe intensamente o ingresso de uma obra no mainstream, pois outros fatores incidem sobre sua escolha, como a viabilidade de comercialização. As competências do artista não são suficientes para o sucesso de sua carreira:

O mercado de arte contemporânea ilustra, ao mesmo tempo, a ambiguidade do conceito de mercado de arte e a fatalidade econômica que pode pesar sobre os artistas. Não porque os que serão reconhecidos não tenham talento, mas, antes, porque a seleção dos vencedores (como a dos excluídos) torna-se completamente aleatória, o que vai contra todos os atributos reconhecidos ao mercado e ao mecanismo de preços (GREFFE, 2013, p. 170).

A triagem estabelecida pelas normas artísticas carece de critérios fixos, muitas variáveis influem na aceitação de uma obra de arte no circuito de museus e galerias, contudo, a inovação ainda seria um valor compartilhado por toda a rede.

É relevante considerar que nem a singularização, nem o mercado de arte são categorias constantes na história da arte. Em termos históricos, a ideia atual de obraprima é tão recente quanto a formação de um mercado para sua negociação. Antes da noção de criatividade e liberdade artística, marcada pelo século XVIII, por meio da academia, da crítica de arte e da estética, que trouxeram outras normas para a circulação de obras de arte no mercado, o ingresso em uma confraria de artistas, a encomenda e a fixação e reprodução de um estilo consolidado constituíam a vida de um artista. O jovem artista formava-se em um ateliê, caracterizado por uma hierarquia rígida de funções, até conseguir, se conseguisse, ser mestre. Com maior autonomia, esse novo mestre poderia criar seu próprio ateliê, que a partir de então produziria obras com seu estilo.

A negociação de obras era feita majoritariamente por encomendas de retratos, paisagens, temas mitológicos e bíblicos, o que tolhia, em uma perspectiva contemporânea, a criatividade do artista, que era dirigida, naquela época, para a consolidação de um estilo apreciado por todos.

A divisão entre artista e artesão inaugurava uma nova perspectiva de mercado: a originalidade passa a ter um papel central na produção artística.

Para Condillac, o critério central é o da originalidade, atribuída ao artista, em oposição à capacidade de imitação, atribuída ao artesão. A imaginação não tem mais nada a ver com a imitação: enquanto um se 
contenta em copiar o poder criador da natureza, o outro interioriza esse mesmo poder (GREFFE, 2013, p. 70).

No entanto o artista deixa de pertencer a uma rede econômica profissionalizada, em que a arte tinha uma função utilitária e por isso tinha um mercado concretizado (atividade artesanal), para conquistar sua liberdade de expressão e trabalhar por vocação. Essa mudança exigia maior "persuasão de venda" da obra de arte, pois não havia uma necessidade de mercado anterior à obra como no período anterior. Esse impacto do único produzido por uma mente criativa estabelecia o conceito de obraprima, que vai comprovar a capacidade de criação artística e vai trazer conceitos de avaliação de compra cada vez mais subjetivos para o mercado.

Essa perspectiva romântica, mais instrumentalizada devido à evolução social e tecnológica ao longo dos séculos, vai caracterizar o mercado de arte até a atualidade e as inscrições urbanas inscrevem-se nesse cenário, cujos valores de singularidade regulam sua produção artística. É no inter-relacionamento dos valores de concentração com as normas sociais e artísticas (mercado de arte) que a arte urbana se desenvolve. No entanto o estabelecimento normativo é determinado pelo uso, ou seja, tanto no campo social quanto no campo artístico suas normas foram conformadas pela repetição, pelo costume.

O uso social do espaço, homogêneo e "asséptico", somado a uma prática legislativa conservadora define a constituição das normas sociais, assim como a implementação dos ideais românticos de genialidade, a desvinculação entre arte e utilidade (arte pela arte) e a formação de crítica especializada direcionaram o gosto artístico da sociedade de consumo, que se cristalizou em função de um mercado cada vez mais distante das exigências dos novos grupos sociais e artísticos (GREFFE, 2013).

Apesar de a norma social estar sempre em oposição aos valores do grafite e da pichação, ela tem maior pertinência para arte urbana, já que ela prioriza sua relação com as normas artísticas. Isso pode ser observado na comparação das leis antigrafite em Nova Iorque nos anos 1980 com as de São Paulo nos anos 2000. As mudanças da visão social sobre essa prática artística vão da total rejeição social à aceitação da arte urbana, da ilegalidade ao prestígio. Porém essa transformação ocorre parcialmente, pois as inscrições urbanas não são toleradas pela sociedade na maioria de suas produções. 
A validação social das inscrições urbanas depende das normas artísticas, ou seja, aquelas obras cujo valor de singularidade é autenticado pelo mercado são poupadas ou recuperadas com o aval das mesmas leis que prescrevem a exclusão daquelas inscrições não pertencentes ao mercado. De um lado, as normas sociais tendem a excluir as inscrições urbanas, de outro lado, elas valorizam as normas artísticas, que assimilam uma parte da produção das inscrições urbanas. Por esse percurso de certificação do mercado de arte, formou-se a modalidade arte urbana.

Assim, as normas sociais não refletem os valores das inscrições urbanas e podem estar relacionadas às normas exógenas, enquanto as normas artísticas, baseadas no mercado de arte, são avaliadas ora como norma endógena, ora como norma exógena, dependendo do tipo de variação de inscrição urbana. Para o grafite e a pichação, as normas sociais e artísticas são encaradas como exógenas e para a arte urbana as normas artísticas são adotadas como normas endógenas.

Como foi definido anteriormente, o valor seria uma constante nas inscrições urbanas, logo, a variável estaria em suas normas. Por isso, a produção de cada modalidade seria constituída na relação entre normas. Ora, duas normas já foram estabelecidas como regras a serem rejeitadas ou aceitas, mas o que não se definiu foi quais seriam os parâmetros. Pensando na origem das inscrições urbanas, verificou-se que para alcançar o valor reconhecimento, os inscritores de tag, throw-up e de mensagens políticas elaboraram suas próprias normas condizentes aos seus valores. A produção de normas endógenas excluiu as normas artísticas e sociais vigentes na época. Essa triagem resultou na associação das inscrições ao vandalismo, na esfera social, e no anonimato artístico perante o mercado de arte, que ignorava sua importância. O desenvolvimento da prática das inscrições urbanas, guiada pelo valor reconhecimento, conduziu a outra forma de singularização, o grafite, que até o momento rejeitava as normas sociais, mas começava a mesclar-se com as normas artísticas.

Do mesmo modo que a autenticidade artística fornecera ao grafite, em um primeiro momento, uma nova estratégia de alcançar o valor reconhecimento. Em um segundo momento, essa relação tornou-se mais forte, pois propiciou uma troca intensa entre normas da arte contemporânea e as normas endógenas do grafite, levando à apropriação da linguagem do grafite pelos artistas, nos anos 1980, como Keith Haring e Miss Tic, e à constituição de movimentos urbanos, como o Hip-Hop. Os valores de 
singularização da arte encontraram na nova linguagem pictórica do grafite e em sua ousada utilização do espaço público um meio de expressão.

Esse processo de mistura entre as normas endógenas das inscrições urbanas e as normas artísticas, que podiam dar os meios para o alcance do objetivo reconhecimento (MERTON, 1970), deu-se inicialmente de maneira átona, o que resultou no grafite, que posteriormente integrou com maior intensidade as normas artísticas formando a arte urbana. Contudo, em outro período, as normas artísticas e sociais foram excluídas desse processo histórico, caracterizando-as como normas exógenas, e outro tipo de inscrição urbana foi criado. As normas exógenas foram desconsideradas pelo grupo social (por exemplo, a pichação), que se encerrava em suas próprias normas, eliminando qualquer possibilidade de reconhecimento via envolvimento com as normas artísticas ou sociais.

A triagem e a mistura entre normas decorreriam das escolhas enunciativas de cada tipo e de cada fase das inscrições urbanas. Embora as normas sociais e artísticas tenham importância na formação das inscrições urbanas, nota-se que em cada fase de sua história uma norma possui maior relevância na constituição de cada modalidade, por exemplo, a pichação e o grafite dialogam mais com as normas sociais e a arte urbana mais com as normas artísticas.

O início do movimento internacional foi marcado pela triagem tônica das normas sociais e artísticas, que foram excluídas em prol das normas endógenas da tag, do throw-up e das inscrições políticas em Paris nos anos 1960 e 1970 . Em seguida, a partir dos anos 1970, a manutenção da exclusão das normas sociais e a mistura átona ou tônica com as normas artísticas marca o surgimento do grafite e da arte urbana, estendendo-se até os dias atuais ${ }^{29}$. Já a triagem tônica do grafite perde intensidade, mas é retomada pelo movimento da pichação, que não percebe nem nas normas artísticas, nem nas normas sociais sua legítima expressão. Enquanto a arte urbana expande-se sob diversos suportes e materiais, a pichação restringe-se a seus próprios recursos.

Apesar da conservação dos valores de concentração, cada movimento segue um percurso distinto, devido a suas escolhas enunciativas em favor da triagem ou mistura. A arte urbana liga-se ao mercado de arte, desenvolve-se esteticamente,

\footnotetext{
${ }^{29}$ Como o valor é constante nos regimes de triagem e mistura, o esquema concentra-se nas relações entre normas, pois essas, sim, são variáveis.
} 
discute as normas sociais sobre o espaço público e privado, difundindo-se de modo heterogêneo. A pichação nega as normas sociais vigentes, inclusive às da arte urbana, para expandir-se pela repetição e transgressão - marcas de sua tipografia complexa. Observam-se, então, essas transições no esquema cronológico abaixo:

Esquema 3. - Cronologia inicial da arte urbana

\begin{tabular}{|c|c|c|}
\hline $\begin{array}{c}\text { Mistura átona } \\
\text { normas artísticas } \\
\text { Grafite (I) }\end{array}$ & $\begin{array}{l}\text { Triage } \\
\text { norma } \\
\text { Grafi }\end{array}$ & sociais \\
\hline 1968 & 1980 & 1989 \\
\hline Tag/Throw-up & Arte Urbana & Pichação \\
\hline Inscrições Políticas & Mistura tônica & Triagem tônica \\
\hline $\begin{array}{l}\text { Triagem tônica } \\
\text { normas sociais }\end{array}$ & $\begin{array}{c}\text { normas endógenas } e \\
\text { artísticas }\end{array}$ & normas sociais $e$ artísticas \\
\hline
\end{tabular}

A partir dos anos de 1990, inicia-se um acúmulo de variações provindas das triagens e misturas efetivadas pelas inscrições urbanas, não somente com as normas sociais e artísticas, mas também com as normas endógenas produzidas por suas triagens e misturas. A mistura tônica do grafite com as normas artísticas criou a arte urbana, a manutenção de sua triagem original conservou-se de modo menos intenso sob o rótulo de grafite Old School, o resgate tônico da triagem original pode ser atribuído à pichação. Essas resultantes continuam a misturar-se e a triar-se subsequentemente, produzindo inúmeras variações ao longo dessas cinco décadas. Por exemplo, as normas endógenas da pichação misturadas às do grafite Old School formaram a variação Grapixo, como também, recentemente, a pichação começa a integrar exposições em galerias e museus, possível resultado da adoção das normas artísticas, relativas à arte urbana, às normas endógenas da pichação. Seguindo a linha histórica: 


\section{Arte Urbana \\ Mistura tônica normas endógenas e artísticas \\ 1990}

Grapicho

Mistura átona normas da pichação $e$ grafite
Pichação-arte

Mistura átona normas da pichaçãoe artisticas

\section{Pichação}

Triagem tônica

normas sociais e artísticas

\section{Grafite (II)}

Triagem átona normas endógenas e sociais

Nota-se que no decorrer da história das inscrições urbanas, a relação entre normas endógenas, sociais e artísticas abre campo para o intercâmbio de outros tipos de normas endógenas, resultantes do primeiro processo. O modelo torna-se mais complexo, pois as escolhas enunciativas de triagem e mistura sobre as normas multiplicam inovações. Isso acontece pela constante tensão entre a representação normativa e o valor desejado.

\subsection{Modelo Normativo}

De acordo com o modelo normativo a ser esboçado, há três fases para a realização de mudanças e conservações formadoras de normas endógenas: inovação, ritualização e conformidade. Os aumentos e diminuições dos valores em relação às normas fundam cada fase. Como foi visto anteriormente, se o valor é constante, o modelo deveria tratar somente das normas. De fato, para a produção de cada modalidade de inscrição urbana, a relação entre normas é mais pertinente que a consideração do valor, já que instabilidade entre normas e valores é uma etapa anterior às adequações. Para que se inicie um processo de inovação, é necessário que as normas não estejam condizentes a seus valores. Dessa instabilidade nasce a inovação, criadora de normas endógenas. A relação entre diferentes normas é 
fundamental para estabelecer as normas endógenas, mas a relação entre normas e valores instaura a necessidade de fazê-lo.

Assim, para compreender essas etapas, é proveitoso definir suas fronteiras, cujo sentido se situa na quantificação. O uso de operadores mais e menos é tomado da semiótica tensiva com a finalidade de determinar esses limites, bem como seu esquema operativo. Aplicam-se, então, as propostas de Zilberberg sobre quantificadores subjetivos ao modelo normativo em construção.

Por uma "quantificação das qualidades e por uma qualificação das quantidades", Zilberberg (2011b, p. 53) propõe um modelo de medição do contínuo tensivo, no qual os operadores mais e menos regulam suas direções. Sua análise revela dependências categoriais, constituídas de unidades. A tabela 2 adiante mostra a rede de relações entre direções $\left(\mathrm{N}_{1}\right)$, categorias $\left(\mathrm{N}_{2}\right)$ e unidades $\left(\mathrm{N}_{3}\right)$, formada pelo acréscimo e retirada de mais e menos. Um regime ascendente tem seu limite na unidade saturação, que só permite sua continuidade em direção contrária, por meio da retirada de um grau mais, a moderação, que dá lugar à diminuição, pela retirada de mais de um grau mais. A categoria relativa à retirada de mais é denominada atenuação, cuja continuação está na minimização, ou seja, no acréscimo de pelo menos um menos - a redução - e de mais de um menos - a extenuação.

Chega-se ao limite da descendência e, do mesmo modo, segue-se com uma mudança de direção pela retirada de um grau menos, a retomada, cuja continuidade se encontra na progressão, retirada de mais de um menos. Enquanto as retiradas de menos formam a categoria restabelecimento, o acréscimo de mais constitui o recrudescimento: de pelo menos um mais, a ampliação, de mais de um mais, a saturação. Consequentemente, retorna-se à saturação, estágio extremo da ascendência, que somente pode ser continuada por um movimento descendente. 


\begin{tabular}{|c|c|c|c|c|}
\hline $\mathrm{N}_{1}$ & \multicolumn{2}{|c|}{$\begin{array}{l}\mathrm{N}_{2} \\
\text { Atenuação } \\
\text { [Cada vez menos mais] }\end{array}$} & \multicolumn{2}{|c|}{$\begin{array}{l}\mathrm{N}_{2} \\
\text { Minimização } \\
\text { [Cada vez mais menos] }\end{array}$} \\
\hline DESCENDÊNCIA & $\begin{array}{l}\mathrm{N}_{3} \\
\text { Moderação } \\
\text { ₹retirada de pelo } \\
\text { menos um mais }\end{array}$ & $\begin{array}{l}\mathrm{N}_{3} \\
\text { Diminuição } \\
\text { ₹retirada de } \\
\text { mais de um mais }\end{array}$ & $\begin{array}{l}\mathrm{N}_{3} \\
\text { Redução } \\
\text { zacréscimo de } \\
\text { pelo menos um } \\
\text { menos }\end{array}$ & $\begin{array}{l}\mathrm{N}_{3} \\
\text { Extenuação } \\
\text { zacréscimo de } \\
\text { mais de um menos }\end{array}$ \\
\hline $\mathrm{N}_{1}$ & \multicolumn{2}{|c|}{$\begin{array}{l}\mathrm{N}_{2} \\
\text { Restabelecimento } \\
\text { [Cada vez menos menos] }\end{array}$} & \multicolumn{2}{|c|}{$\begin{array}{l}\mathrm{N}_{2} \\
\text { Recrudescimento } \\
\text { [Cada vez mais mais] }\end{array}$} \\
\hline ASCENDÊNCIA & $\begin{array}{l}\mathrm{N}_{3} \\
\text { Retomada } \\
\text { zretirada de pelo } \\
\text { menos um menos }\end{array}$ & $\begin{array}{l}\mathrm{N}_{3} \\
\text { Progressão } \\
\text { zretirada de } \\
\text { mais de um } \\
\text { menos }\end{array}$ & $\begin{array}{l}\mathrm{N}_{3} \\
\text { Ampliação } \\
\text { zacréscimo de } \\
\text { pelo menos um } \\
\text { mais }\end{array}$ & $\begin{array}{l}\mathrm{N}_{3} \\
\text { Saturação } \\
\text { zacréscimo de } \\
\text { mais de um mais }\end{array}$ \\
\hline
\end{tabular}

(ZILBERBERG, 2011b, p. 60)

Ao observar as interações entre normas e valores, o modelo tensivo torna-se relevante na explicação de suas flutuações representadas pelos modos inovação, ritualização e conformidade. Vistos pelos eixos tensivos, normas e valores estariam ligados à extensidade e à intensidade e as direções descendentes e ascendentes operariam as gradações de cada eixo. Baseado no esquema tensivo sobre as gradações lexicais, em língua francesa, no campo semântico relativo ao medo (ZILBERBERG, 2012, p. 102), propõe-se um desdobramento dessa representação gráfica ao modelo normativo, com adaptações exigidas pela análise do fenômeno.

Dessa forma, tanto a descendência quanto a ascendência integrariam cada eixo, pois o movimento de acréscimo e redução formaria cada dimensão, por isso foi imposta uma adaptação da quantificação subjetiva ao esquema tensivo. Para manter as duas direções em um mesmo eixo, colocou-se abreviadamente, em pares, cada unidade pertencente a direções opostas. Em itálico, lê-se o percurso ascendente, constituído pelo restabelecimento e recrudescimento e em negrito, o percurso descendente, composto pela atenuação e minimização. Os extremos, saturação e 
extenuação, integram ambas as direções, por isso não estão pareados, não possuem destaque tipográfico e não estão abreviados.

\section{Esquema 5 - Gradações tensivas no modelo normativo}

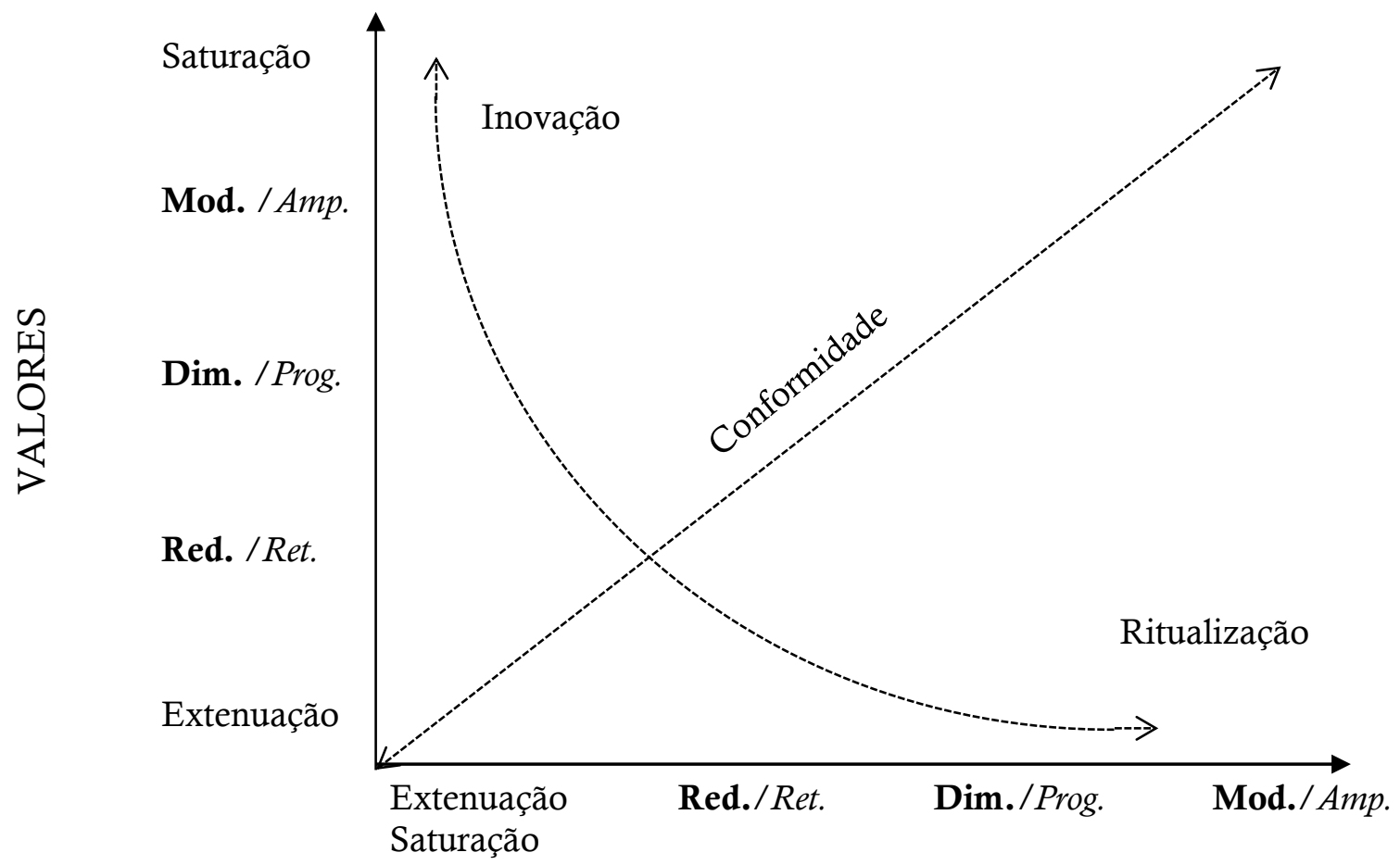

NORMAS

As relações conversas "e...e" constituiriam a conformidade, pois a conjunção entre normas e valores proporcionaria uma reciprocidade entre as valências. $\mathrm{O}$ fato de haver conformidade não significaria uma parada, mas, sim, uma recíproca continuidade entre normas e valores, ou seja, o aumento e a diminuição ocorreriam em ambas as dimensões concomitantemente. Já a inovação e a ritualização seriam formadas pelas relações inversas "ou... ou", visto que normas e valores se distanciariam gradativamente até o limite, marcado pela saturação e extenuação. No entanto o emprego exclusivo da quantificação torna insuficiente a descrição do fenômeno normativo, formado por um movimento, cuja variação no andamento traz diferenças de sentido.

Sabe-se que o andamento é uma subdimensão da intensidade, mas ao tratar das relações quantitativas, Zilberberg (2011b) propõe que a passagem de uma unidade $\left(\mathrm{N}_{3}\right)$ a outra pode ocorrer com velocidades distintas, desse modo, a lentidão e a celeridade regulam o andamento, cuja associação às direções de ascendência e descendência 
resulta em efeitos de sentido como adição, subtração, multiplicação e divisão. Pela lentidão, a ascendência produz a adição e a descendência produz a subtração e, pela celeridade, elas produzem a multiplicação e a divisão (ZILBERBERG, 2011b, p. 61). Então, o andamento das ascendências e descendências, em uma relação inversa, define tipos de inovação, bem como repercute no conceito de conformidade. Para isso, analisam-se as categorias separadamente.

\subsubsection{INOVAÇÃO E RITUALIZAÇÃO}

Marcada inicialmente por uma situação extrema, a inovação efetiva-se pelo movimento entre dois pontos principais, denominados instauração e resolução. No primeiro ponto, não há influência significativa do andamento, já que se trata de um estado inicial, no qual os valores recrudescem e as normas minimizam-se ${ }^{30}$. No segundo ponto, instaura-se a resolução do estado inicial para sua conclusão em um novo estado de conformidade. O percurso de transformação do regime inverso para o regime converso define a categoria inovação.

A chegada dos valores ao extremo da ascendência e das normas ao limite da descendência levaria à resolução dessa discrepância, por meio de um movimento ascendente das normas ou por um movimento recíproco de ascendência normativa e descendência de valor ${ }^{31}$. Neste, normas e valores têm seu encontro na "metade do caminho", ora com a rapidez na descendência dos valores e na ascendência das normas, ora com a lentidão no mesmo percurso. Naquele, os valores saturados são atenuados lentamente, ao passo que as normas extenuadas rumam ao recrudescimento rapidamente.

O conceito de normas endógenas - exigência de mudança normativa por causa da saturação do valor - define a instauração da inovação pelo termo inovação endógena e a etapa da resolução é definida pelos especificadores determinante, que trata da rápida

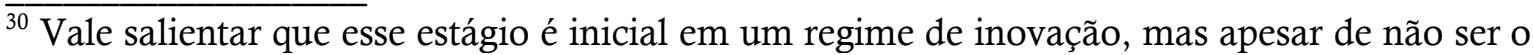
objetivo desta investigação, não se desconsidera o fenômeno anterior que provoca a inovação, no qual o andamento teria pertinência.

${ }^{31} \mathrm{Na}$ inovação os valores vão reger as normas, por isso as duas alternativas.
} 
ascendência das normas em função da saturação dos valores, e interdependente, caracterizado pelo movimento recíproco de ambas as dimensões. A nomeação dos termos segue os tipos de dependência em uma função propostos por Hjelmslev (1974, p. 64), na interdependência, os dois elementos são constantes e, na determinação, um elemento é constante e outro variável.

Considera-se inovação endógena determinante, quando o excesso do valor exige a mudança célere da norma extenuada; por exemplo, a formação do grafite de Nova Iorque e de Paris, cujos valores rapidamente geraram novas normas. Já a inovação endógena interdependente caracteriza-se pela identidade de andamento entre normas e valores na etapa da resolução, porém, a possibilidade de dois modos de andamento cria dois termos especificadores da interdependência: à descendência lenta dos valores e à ascendência lenta das normas, denomina-se inovação endógena interdependente progressiva, e ao andamento célere na mesma relação, denomina-se inovação endógena interdependente imediata $^{32}$. Uma vez que o andamento progressivo ou imediato da inovação endógena pressupõe a interdependência, reduzse o termo para inovação endógena progressiva ou inovação endógena imediata. $\mathrm{O}$ caso de estabelecimento da arte urbana em longo prazo, que mistura normas artísticas às normas endógenas do grafite, é um exemplo de conformidade progressiva entre valores recrudescidos e normas minimizadas. Outro exemplo de interdependência é visto no acontecimento exposto por Klinkenberg (2010) sobre a literatura francófona fora da França, no qual as normas linguísticas regionais promovem uma adequação em função das normas da língua francesa, resultando em uma língua francesa regional. $\mathrm{O}$ andamento dessa inovação especificaria cada grupo por suas relações com as normas francesas.

Percebe-se também que a inovação não é exclusiva das normas endógenas e pode ser aplicada ao modelo de exogênese. A inovação exógena consiste na instauração de normas recrudescidas e valores minimizados, cuja resolução pode ocorrer com a descendência lenta das normas e a ascendência célere dos valores, caracterizando a determinação. Enquanto nas inovações endógenas, os valores regem as normas, na inovação exógena, o processo inverte-se. Esse é o caso das leis nova-

\footnotetext{
$\overline{32} \mathrm{O}$ termo imediato é ambíguo, pois pode ser definido pela ausência de mediação, mas também pela instantaneidade. Nesse caso, sua definição liga-se àquilo "que não tarda, temporalmente muito próximo; que não permite demora" (BORBA, 2004, p. 735). Como a proposta é nova, não são desconsideradas sugestões terminológicas com menor ambiguidade.
} 
iorquinas sobre a proibição do grafite no metrô, pois com a imposição normativa, os valores dos sprayers foram minimizados e adaptaram-se em função da norma exógena, abandonando o metrô. A resolução lenta dos valores em função das normas determina a inovação exógena (interdependente) progressiva. A pichação-arte seria um exemplo nas inscrições urbanas, pois os valores do grupo vão perdendo força por causa da pressão das normas artísticas e sociais, mantendo a constante reconhecimento, e o até então inaceitável começa a ser delineado nos tempos atuais: uma pichação que se insere no mercado de arte.

A inovação exógena (interdependente) imediata, célere ascensão de valores e descendência de normas, sucede, em um exemplo fora do escopo das inscrições urbanas, em empresas que permitem o Home Office para funcionários. A obrigação de ir à empresa flexibiliza-se em razão da possibilidade de o trabalho ser feito independentemente de seu espaço, ou seja, normas e valores adequam-se rapidamente.

Nesse processo de instauração da instabilidade, verifica-se que a relação norma/valor é essencial, mas a etapa resolução, que visa uma conformidade entre novas normas e valor, exige uma recuperação das relações normativas colocadas anteriormente. Essa resolução é processualmente vista como uma adequação quantitativa das normas em relação aos valores, no caso da inovação endógena, e dos valores em relação às normas, no caso da inovação exógena, porém, nesse estágio, as escolhas enunciativas por meio de triagens e misturas serão as responsáveis pela criação de novas normas, ajustadas aos valores.

Embora o modelo explique as relações tensivas da inovação, ressalta-se que a resolução deve ser entendida, sobretudo, pela oposição normativa, ou seja, o enunciador para manter seus valores de reconhecimento busca reformular normas, incorporando outras normas ou excluindo qualquer possibilidade de mistura. Com a finalidade de alcançar a continuidade, a conformidade produz uma distensão. Por isso, a geração de cada modalidade foi posta em razão dessas triagens e misturas enunciativas, já que são elas as responsáveis por essa adequação entre valores e normas.

Essa relação entre normas concentra as duas etapas, já que pressupõe a instauração e por meio dela a resolução é concluída. Além disso, essa resolução normativa define o andamento de cada inovação. A lentidão e a celeridade no ajuste entre normas e valores dependem das triagens e misturas normativas efetuadas pelo 
enunciador em determinado período de tempo. A saturação dos valores ou normas exige sua resolução, que pode entrar em conformidade durante um curto período de tempo ou tardar para se estabilizar, devido às triagens e misturas realizadas.

Por exemplo, para determinar o andamento de um deslocamento de um carro que faz um percurso de um ponto $\mathrm{A}$ até um ponto $\mathrm{B}$, o tempo levado para concluir o caminho é fundamental, ou seja, se um carro conclui o percurso em 1 hora e outro, sob as mesmas condições, o faz em um dia, o primeiro pode ser considerado mais rápido que o segundo. Assim como, se para o primeiro carro é deixado o percurso livre e para o segundo são colocados obstáculos, o andamento também será alterado. Esse exemplo de aula de Física do Ensino Médio é relevante para pensar no tempo e nos obstáculos relativos às triagens e misturas normativas na história das inscrições urbanas.

O percurso feito pelo exemplo anterior, nesse caso, é o da instauração à resolução. O tempo é o histórico, que só pode ser visto como mais longo ou mais curto, se eventos distintos forem comparados, e os obstáculos são as diferentes normas a serem triadas ou misturadas. Comparando as normas endógenas da tag com as normas endógenas da arte urbana, pode-se obter uma ideia mais concreta sobre o andamento.

A tag foi instaurada pela saturação dos valores em relação à extenuação de normas sociais. Sua resolução deu-se por determinação criando as normas endógenas daquela modalidade. Nesse processo de adequação normativa, o enunciador grupo social excluiu as normas sociais vigentes e criou suas próprias normas. Como foi visto na história das inscrições urbanas, essa prática foi estabilizada, divulgada e saturada em um período aproximado de oito anos, pois começou no fim dos anos 1960 e no fim dos anos 1970, já era hostilizada socialmente. Somado a isso, houve uma queda no número de inscritores que faziam tag no fim dos anos 1970, se comparado ao seu período inicial, pois o grafite era a nova moda das inscrições urbanas.

Dessa forma, considera-se a tag uma inovação determinada, devido ao curto período de tempo para tornar-se conforme, quer dizer, pela produção direta de normas endógenas, sem intermediários normativos. A consideração do período curto da tag baseia-se na comparação com outras modalidades. Por exemplo, a arte urbana.

Enquanto a tag seria pioneira na produção de normas endógenas nas inscrições urbanas, o que significa ter o "caminho livre" para estabelecer-se, a arte urbana ao ser 
constituída enfrentou um cenário diferente, pois ela parte de normas já estabelecidas nas inscrições urbanas. Provinda do grafite old school, a arte urbana nasce da insatisfação dos valores de reconhecimento em relação às triagens das normas daquela modalidade, visto que sua mistura mais intensa com as normas artísticas lhe trazia o reconhecimento desejado. Para poder adequar-se aos seus valores, o processo de instauração nega as normas vigentes do grafite, consideradas insuficientes, para afirmá-las na resolução em uma conjunção com outras normas.

Esse processo de mediação entre normas do grafite e normas artísticas com a finalidade de atingir um ajuste em prol dos valores de reconhecimento exigiria maior "energia" do enunciador e por isso, levaria a uma ascendência lenta das normas, caracterizando uma inovação endógena progressiva. Essa tendência à lentidão é corroborada pela observação da arte urbana na história, que, todavia, segue atualmente em transformação, não obtendo a mesma estabilidade da tag. A arte urbana possui uma conformidade instável, porque se mistura com as normas artísticas, cuja tendência à originalidade indefine as normas. Definir o que é arte tem a mesma imprecisão no que se refere à definição de arte urbana. Mesmo com o critério do mercado de arte, a efemeridade de aceitações que se tornam rejeições pelo mesmo mercado é corrente. Por conta dessa imprecisão das normas, seu processo tardaria mais, visto os processos de outras modalidades.

Enquanto a tag, o throw-up, a pichação e o grafite possuem normas endógenas bem delineadas, a arte urbana carece dessa disposição, logo, há um movimento contínuo de breves conformidades e inovações, que não alteram a identidade da modalidade em uma perspectiva global, somente proporcionam uma lentidão para atingir uma conformidade durativa e estável.

\subsubsection{RituALIZAÇÃo}

É relevante ressaltar que a consequência de cada inovação é a conformidade, porque a transformação acontece para estabilizar uma extrema disparidade. Embora a continuidade qualifique a inovação, a parada dessa continuidade cria outras relações. 
Logo, a ritualização pode ser entendida como uma parada na instauração da inovação exógena, isso quer dizer, a saturação das normas e a extenuação dos valores sem o movimento de resolução em direção à conformidade.

Visto que a inovação exógena é caracterizada pela transformação dos valores por meio das normas, a ritualização enquadra-se no momento em que as normas regem sua relação de não conformidade com os valores. Assim, os valores minimizados seguem uma inércia normativa, pois a inovação demanda certa intensidade dos valores que não condiz com a situação de regência normativa. Tanto pela facilidade de "se deixar levar", quanto pelo alto controle normativo, os valores acabam conduzidos "cegamente" pelas normas.

Em poucas palavras, é o modo de adaptação para procurar individualmente uma fuga particular dos perigos e frustrações que parecem a eles inerentes na competição pela obtenção dos objetivos principais, pelo abandono de tais objetivos, agarrando-se o quanto mais estreitamente às rotinas seguras e às normas institucionais (MERTON, 1970, p. 224).

Nas inscrições urbanas, a ritualização ocorre quando uma modalidade é estabilizada pela conformidade entre normas e valores durante um longo período de tempo e torna-se um estilo plástico desligado da prática. Por exemplo, o grafite old school estabeleceu variedades de letras e estilos, como o wild style e bubble letters, por conta do valor reconhecimento e pela inserção átona das normas artísticas relacionadas à originalidade. Porém, atualmente, essas variedades tornaram-se normas e a produção de novas variedades tipográficas terminou. A competição entre os grafiteiros ainda se preserva, mas com uma repetição de estilos dos anos de 1970 que não condiz com a prática. A criação de variedades estilísticas motivava a competição, atualmente a reprodução dessas variedades clássicas massifica a competição, menos intensa que anteriormente.

Todas essas relações são visualizadas na tabela a seguir, em que a seta para cima significa ascendência na direção (Dir.) e celeridade no andamento (And.). A seta para baixo significa descendência na direção (Dir.) e lentidão no andamento (And.). Por fim, o quadro sem seta denota ausência de continuidade para a resolução. 


\begin{tabular}{|c|c|c|c|c|c|c|c|}
\hline & & \multicolumn{2}{|c|}{ INSTAURAÇÃO } & \multicolumn{4}{|c|}{ RESOLUÇÃO } \\
\hline & & \multirow{2}{*}{$\frac{\text { Normas }}{\text { Dir. }}$} & \multirow{2}{*}{$\begin{array}{c}\text { Valores } \\
\text { Dir. }\end{array}$} & \multicolumn{2}{|c|}{ Normas } & \multicolumn{2}{|c|}{ Valores } \\
\hline & & & & Dir. & And. & Dir. & And. \\
\hline \multirow{3}{*}{$\begin{array}{l}\text { Inovação } \\
\text { Endógena }\end{array}$} & Determinante & $\downarrow$ & $\uparrow$ & \multicolumn{2}{|c|}{$\uparrow$} & \multicolumn{2}{|c|}{ 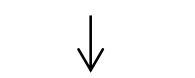 } \\
\hline & $\begin{array}{c}\text { (Interdependente) } \\
\text { Progressiva }\end{array}$ & $\downarrow$ & $\uparrow$ & $\uparrow$ & $\downarrow$ & \multicolumn{2}{|c|}{$\downarrow$} \\
\hline & $\begin{array}{l}\text { (Interdependente) } \\
\text { Imediata }\end{array}$ & $\downarrow$ & $\uparrow$ & & $\uparrow$ & $\downarrow$ & $\uparrow$ \\
\hline \multirow{3}{*}{$\begin{array}{l}\text { Inovação } \\
\text { Exógena }\end{array}$} & Determinante & $\uparrow$ & $\downarrow$ & \multicolumn{2}{|r|}{$\downarrow$} & \multicolumn{2}{|c|}{$\uparrow$} \\
\hline & $\begin{array}{c}\text { (Interdependente) } \\
\text { Progressiva }\end{array}$ & $\uparrow$ & $\downarrow$ & \multicolumn{2}{|r|}{$\downarrow$} & $\uparrow$ & $\downarrow$ \\
\hline & $\begin{array}{l}\text { (Interdependente) } \\
\text { Imediata }\end{array}$ & $\uparrow$ & $\downarrow$ & $\downarrow$ & $\uparrow$ & & $\uparrow$ \\
\hline \multicolumn{2}{|c|}{ Ritualização } & $\uparrow$ & $\downarrow$ & & & & \\
\hline
\end{tabular}

Em síntese, as inovações endógenas e exógenas propõem a instauração do regime inverso entre normas e valores, ora na saturação dos valores (inovação endógena), ora na saturação das normas (inovação exógena). Segue-se pela resolução, cuja diferença ou uniformidade de andamento revela a determinação ou a interdependência. A aproximação lenta e simultânea entre normas e valores na interdependência é chamada de progressiva e o mesmo percurso com andamento célere é denominado imediato. A inovação endógena englobaria a rebelião (MERTON, 1970) e a inovação exógena estaria vinculada a ritualização. Ressaltando que a diferenciação entre as inovações endógenas e exógenas são determinadas pela saturação dos valores, no primeiro caso, e das normas, no segundo caso. Verifica-se, assim, a consequência de todo esse movimento de resolução: a conformidade entre normas e valores. 


\subsubsection{CONFORMIDADE}

O sentido do processo de inovação ruma ao equilíbrio das tensões entre normas e valores, porém essa estabilidade não significa uma parada da continuação, pois cada categoria de inovação produz distintos modos de conformidade, cuja flutuação entre mais e menos ainda demonstra certa instabilidade. De fato, se não houvesse algum tipo de movimento entre normas e valores no regime da conformidade, não haveria mudança após seu estabelecimento. Em termos tensivos, a intersecção entre as dimensões intensivas e extensivas em um regime converso determina a conformidade, cuja gradação é formada pela resultante de cada tipo de inovação.

As inovações endógena e exógena determinantes levam a conformidade a um campo ascendente, já que a atenuação lenta e o recrudescimento célere mantém a conformidade em uma zona entre moderação e ampliação, dependendo de sua direção. As inovações progressivas e imediatas por sua uniformidade seriam estabilizadas nos graus de diminuição e progressão, elas somente seriam distinguidas pelo tempo que levariam para entrar em conformidade.

Esquema 6 - Graus de Conformidade

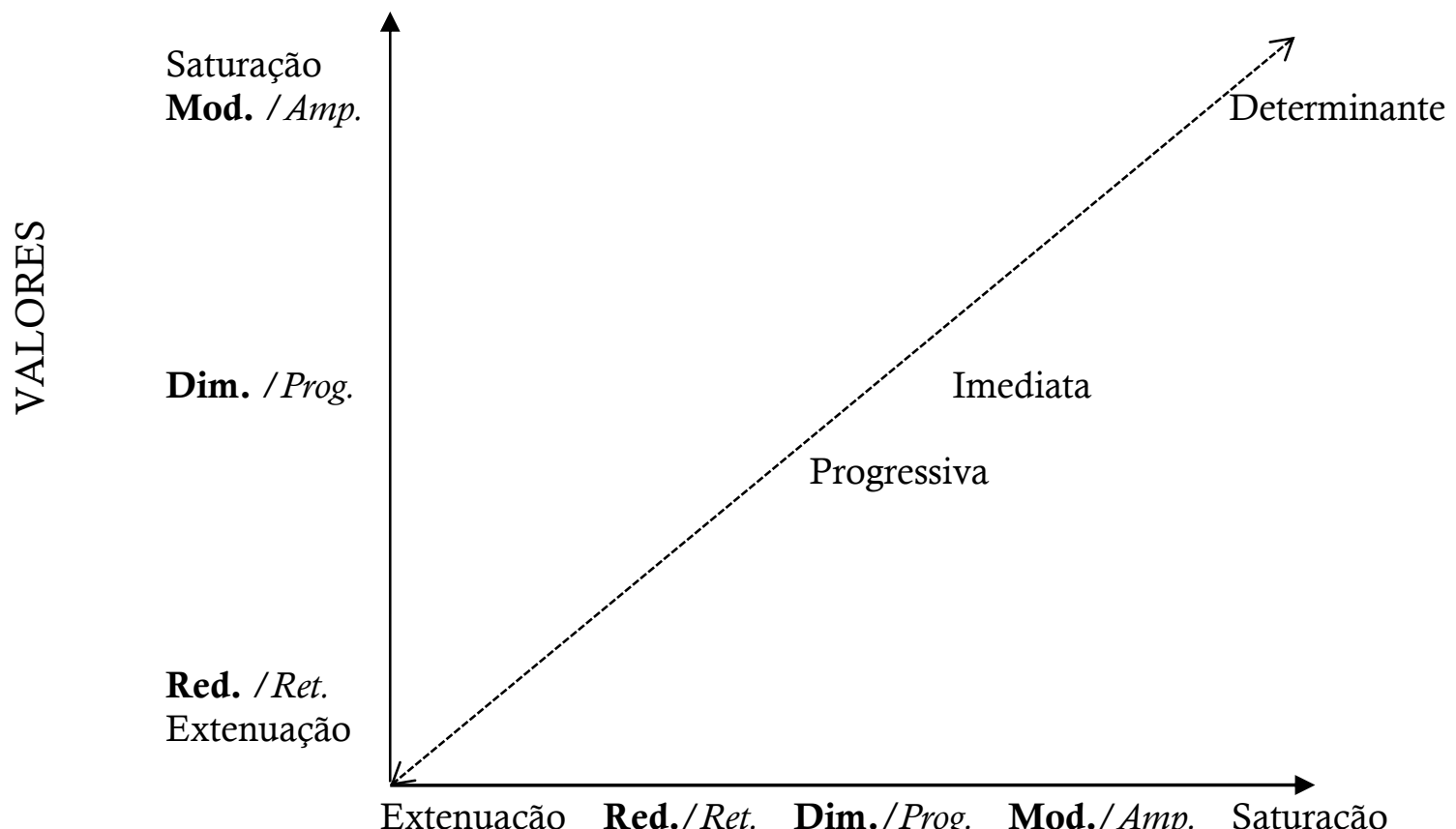


A partir dessas zonas de conformidade, flutuantes entre saturação e extenuação, uma mudança de direção poderia ocorrer na relação entre normas e valores, levando a um regime inverso. Ao atingir os extremos de cada eixo por meio do regime inverso, seria formada a instauração de inovações ou ritualizações. Essa transposição do regime inverso ao regime converso seria possível pelo fato de as normas, repetição de um uso determinado por um grupo ou indivíduo, terem um caráter mais estável que os valores, sensíveis às mudanças enunciativas. A inteligibilidade normativa imporia maior estabilidade para sua fixação, ao passo que o aspecto sensível do valor caminharia de acordo com os desejos do enunciador, sensibilizado também pelo contexto histórico. Quando essas duas dimensões não se correspondessem adequadamente, para a estabilidade da conformidade, seria gerada uma tensão, cujo aumento provocaria a mudança do regime converso da conformidade para o regime inverso da instauração da inovação ou da produção da ritualização.

Apesar do dinamismo do fenômeno, haveria uma tendência ao estável, pois a constante inovação afetaria a inteligibilidade da apreensão do sentido. A instabilidade do valor em relação às normas somente chega à inovação quando seu campo de variação ultrapassa o campo normativo, pela saturação ou extenuação. Contrariamente aos preceitos da semiótica tensiva ${ }^{33}$, na conformidade, a extensidade regeria a intensidade, pois o valor seria regulado pelas normas, até que a persistência de dado valor, em oposição às normas, criasse direções inversas das dimensões, nesse momento, a intensidade, o valor, seria regente.

Se toda inovação tem como fim sua conformidade em relação às normas, podese observar que um grupo social pode até abdicar de seus valores para estar na inércia normativa, no entanto, não é possível encontrar um grupo social que vive somente à base de seus objetivos, de seus desejos, pois regras são ajustadas para atingir esses objetivos: "a conformidade absoluta torna-se um valor central" (MERTON, 1970, p. 206). A sociedade é marcada pelo controle normativo, seja ele conforme, seja ele não conforme.

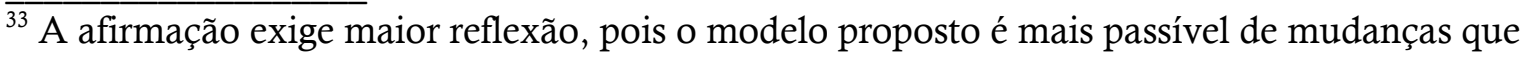
as premissas já consolidadas da semiótica tensiva.
} 
Na medida em que uma sociedade é estável, o tipo I de adaptação conformidade tanto com os objetivos culturais como com os meios institucionalizados - é a mais comum e a mais difundida extensamente. Se assim não fosse, não se poderia manter a estabilidade e continuidade sociais (MERTON, 1970, p. 214).

Essa pressão social pelo dever, levada às últimas consequências, passa a reprimir os valores que, chegados à extenuação, só teriam o percurso ascendente como consequência, na lógica tensiva (ZILBERBERG, 2011b).

O modelo exposto parece ser pertinente para o estudo das inscrições urbanas, não obstante, compreende-se que não houve desenvolvimento de determinadas partes, como a exploração da extenuação no regime inverso. Por causa de o corpus ter uma tendência à inovação intensa, a mudança de valores das inscrições urbanas parece estar adequada à proposta, o que leva o modelo a concentrar-se em uma perspectiva de ascendência.

Analisar o fenômeno das inscrições urbanas sob o modelo em desenvolvimento ajuda a entender suas relações normativas e possibilita uma reflexão sobre a norma como expressão da relação entre o dever e o querer. Pensando nas possibilidades enunciativas de triagem e mistura entre normas, verificam-se mais detidamente os tipos de intervenção urbana.

\subsection{Modalidades}

Cada modalidade é apresentada de acordo com suas características e aponta seu lugar no modelo normativo. Vários estilos foram excluídos por conta da premissa de utilizar inscrições urbanas relacionadas à técnica da pintura. Por isso, stickers, esculturas e performances não foram abordadas. O lambe-lambe não foi englobado, pois ele foi considerado como uma técnica do cartaz. Além disso, a escolha das modalidades foi pautada em sua posição estrutural na história das inscrições urbanas e as outras técnicas não mencionadas podem ser consideradas como desdobramentos das modalidades elencadas a seguir. 


\subsubsection{INSCRIÇÕES POLÍTICAS}

Provindas do Maio de 68 em Paris, as inscrições políticas são caracterizadas por uma tipografia simples e pela utilização dos muros como suporte. $O$ valor reconhecimento ainda está sendo consolidado em função de valores político-sociais, a reprodução de frases nos muros parisienses busca o engajamento da população, mas ao mesmo tempo emprega recursos poéticos para fazer-se ver. A carência de desenvolvimento visual é compensada pela elaboração no plano do conteúdo e no plano da expressão verbal.

Além de informar ou engajar o enunciatário, as inscrições políticas já atentavam para a sua sensibilização por meio de recursos poéticos. Fazer com que o enunciatário reconhecesse os slogans políticos reproduzidos na cidade é um modo de diferenciar-se das outras comunicações públicas, bem como o nível de desenvolvimento poético de cada inscrição política gerava certa competição entre seus produtores. Mostrar suas habilidades como escritor, comunicador e ativista político sob a forma concentrada de uma frase no muro entrava no escopo da prática.

Figura 42 - Inscrição política parisiense ${ }^{34}$

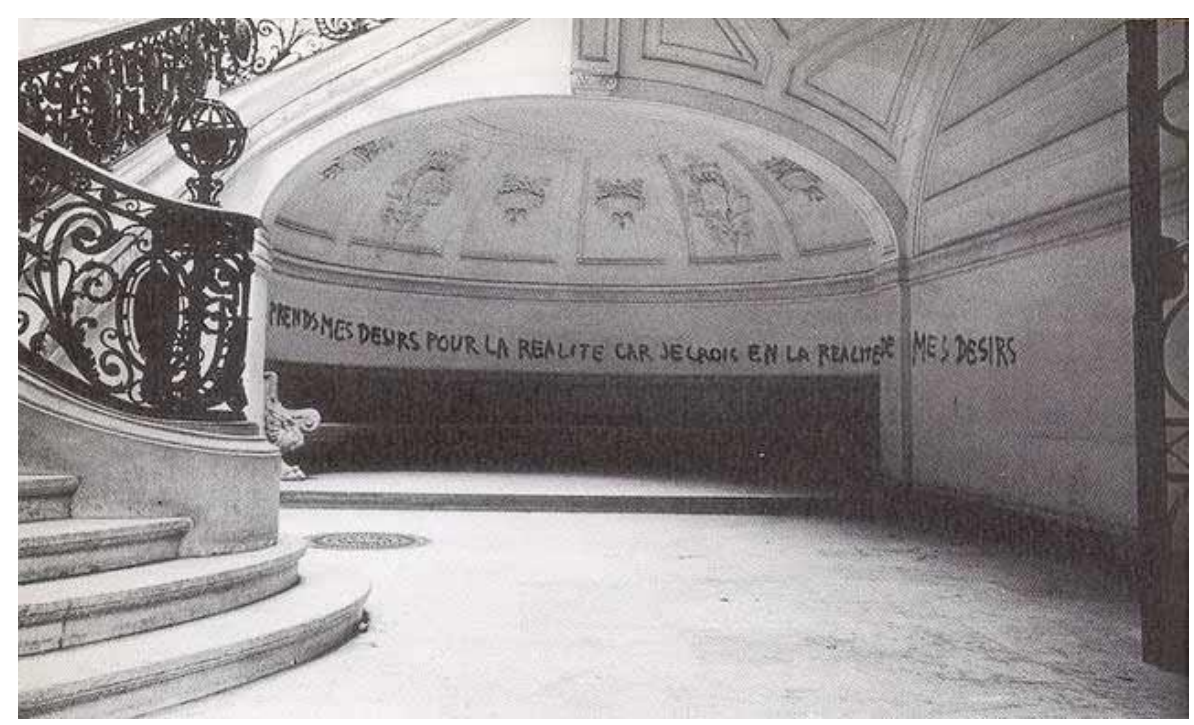

(INVENTIN, 2016)

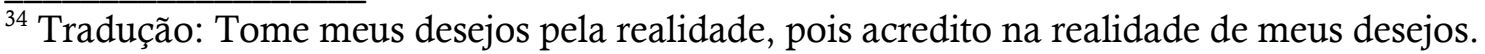


A transgressão de um espaço público para comunicar-se aproxima as inscrições urbanas parisienses das de Nova Iorque, a forma de fazê-la distingue essas modalidades, pois enquanto estas inscrições exploram a linguagem visual, aquelas são essencialmente desenvolvidas na semiótica verbal e enquanto o valor reconhecimento almejado pelas inscrições estadunidenses é conduzido para uma autopromoção, nas inscrições políticas, ele é buscado para uma conscientização da população. Esse caráter político vai perder sua intensidade ao longo da história das inscrições urbanas, mas será recuperado por alguns artistas como Miss.tic e Banksy.

$\mathrm{Na}$ relação entre normas, as inscrições políticas são formadas do mesmo modo que as tags, a saturação dos valores e a extenuação das normas instauram a necessidade de resolução, que vai em direção da exclusão das normas sociais para a inovação endógena determinante. No entanto o contexto social molda as normas de cada região. No Maio de 68, o conservadorismo, nas tags, a exclusão social.

\subsubsection{TAGE THROW-UP}

Tag, termo em inglês que designa etiqueta, é o nome elaborado em forma de assinatura codificada, com traços simples, de fácil reconhecimento, reproduzida rápida e repetidamente pelo inscritor.

Figura 43 - Metrô de Nova Iorque repleto de tags

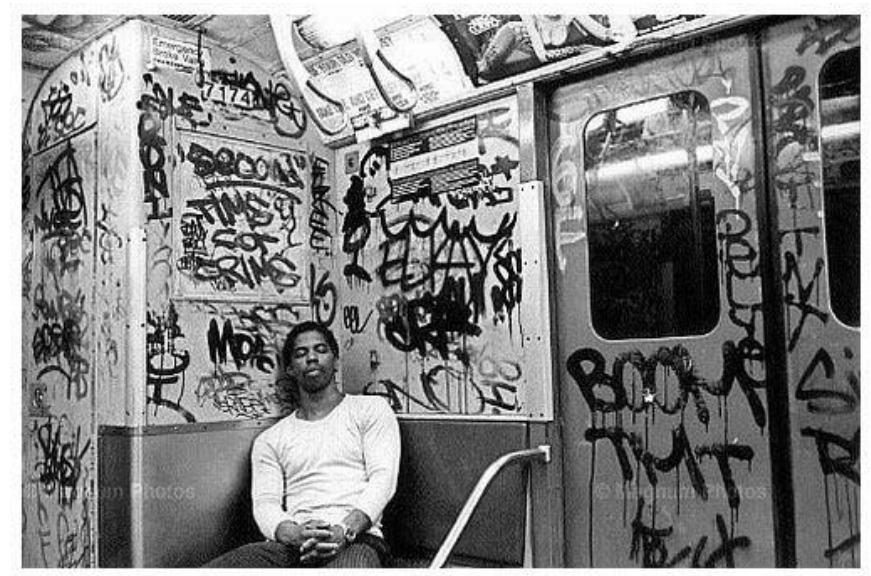

(SANDLER, 2016) 
Throw-up, que em inglês significa "vômito", é um estilo entre a tag e o grafite, pois é feito de forma rápida e repetitiva, mas com maior elaboração tipográfica em comparação à tag, ou seja, escrito em duas letras arredondadas e em duas cores, sendo uma o contorno, a outra o preenchimento (ELLSWORTH-JONES, 2013, p. 43).

Figura 44 - Throw-up de Haze, Nova Iorque anos 1970

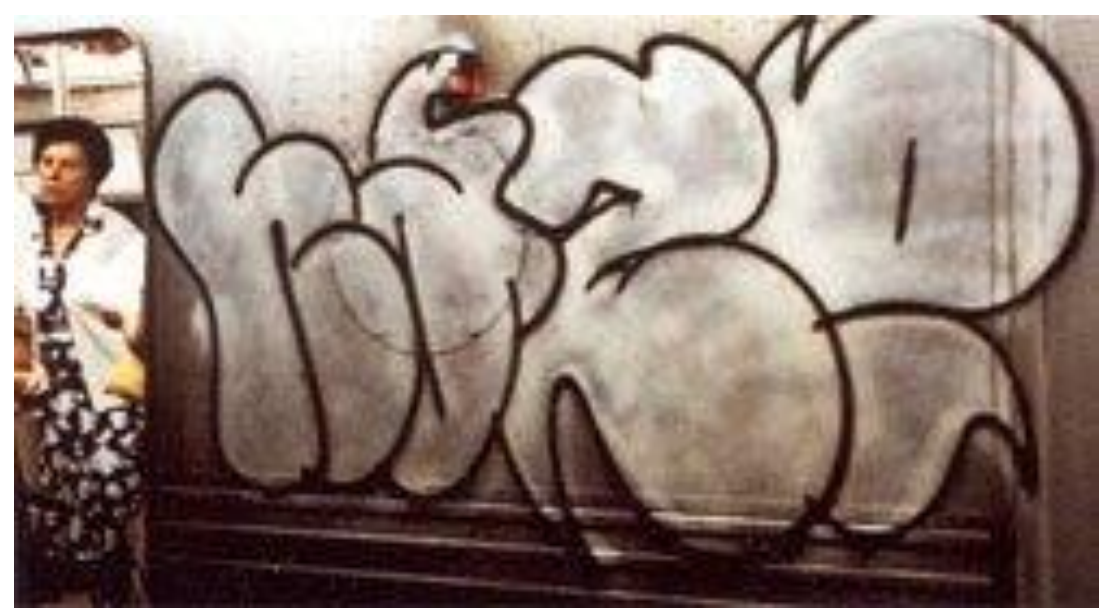

(SUBWAY OUTLAWS, 2016)

Iniciadores do movimento que se desdobrou nas diversas modalidades de intervenção urbana, a tag e o throw-up, em disjunção com as normas sociais, promovem a seleção de seus valores e marca a inovação endógena pela instauração de valores saturados e normas extenuadas. $\mathrm{Na}$ etapa de resolução, normas sociais são adequadas aos valores de concentração ligados ao reconhecimento e a interdição social ganha relevância enquanto limite para transgressão. Rapidamente, as normas sociais são mudadas e novas normas são estabelecidas pelo grupo, caracterizando a inovação endógena determinante.

A conformidade da tag e do throw-up proporcionou sua consolidação pelos valores de concentração e pela triagem tônica das normas sociais, mas durante os anos de 1970, a diminuição de intensidade na triagem conduziu a tag e o throw-up a uma recuperação da intensidade dessa triagem por meio do grafite. $\mathrm{O}$ excesso de produção e o estabelecimento de regras rígidas para realização da prática levaram a sua rápida saturação e por consequência, a uma perda significativa do valor reconhecimento. Por exemplo, o estilo padronizado das letras, com uma tipografia arredondada, o uso indiscriminado do suporte e a repetição excessiva homogeneizaram a prática, que 
exigia cada vez mais uma maior reprodução da assinatura para alcançar o valor reconhecimento. O caso de IN quantifica o percurso para tornar-se um king:

Os pintores especializados em vagões inteiros, como Lee ou Blade, qualificavam abertamente o throw-up como um "monte de lixo" e lamentaram-se de que a popularidade que estava sendo alcançada por ela supunha a morte do grafite. IN celebrou seu throw-up número cinco mil com a pintura de um vagão inteiro de forma espetacular, coberto de estrelas e de colorido igual a um arco-íris. Como se quisesse demonstrar que ele também podia fazer peças maiores, se assim o fizesse. Em seguida, voltou a seus throw-ups sem graça, e dizem que não parou de fazê-los até alcançar o número dez mil. Nesse momento, segundo Tracy 168, "IN foi declarado rei de todas as linhas" [do metrô] ${ }^{35}$ (CASTLEMAN, 2012, p. 92-93, tradução própria).

Assim, a repetição exaustiva da tag desencadeou uma tentativa de diferenciação plástica para obtenção do reconhecimento: o throw-up. Contudo as normas da tag foram preservadas nessa evolução tipográfica, chegando aos mesmos impasses. Ao longo do tempo, as duas modalidades já não representavam tão bem os valores de reconhecimento exigidos por uma parte do grupo e a alta intensidade da triagem feita pelo enunciador no início torna-se átona, graças ao surgimento de novas modalidades, à manutenção das normas estabelecidas e à tolerância social à prática. Por essa restrição, a prática deixou de ser novidade, diluiu-se na massificação da produção e já não gerava o impacto almejado na cena enunciativa, em decorrência disso, as modalidades tornaram-se estáveis e atualmente suas normas não exigem uma numerosa reprodução.

A falta de adequação aos valores de reconhecimento fez com que a lógica da quantidade fosse substituída pela lógica da qualidade. $\mathrm{O}$ reconhecimento deveria ser atingido, a partir de então, pela elaboração plástica de poucas obras, ao invés da multiplicação de obras simples. Surge o grafite.

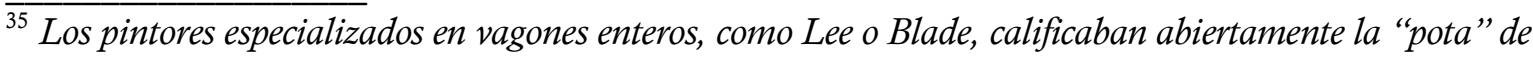
"montón de basura" y empezaron a lamentarse de que la popularidad que estaba alcanzando suponía la muerte del grafiti. IN celebró su pota número cinco mil pintando un "vagón entero" de lo más espectacular, cubierto de estrellas y colorido cual un arco iris, como si quisiera demostrar que él también podia hacer piezas mayores si lo proponía. Luego volvió a sus pálidas y churretosas potas, y se dice que no paró hasta que hubo completado la número diez mil.
} 


\subsubsection{GRAFITE}

$\mathrm{Na}$ busca pelo reconhecimento, parte do grupo social não via mais nas modalidades das inscrições urbanas vigentes (tag e throw-up) um modo de alcançar seus valores. Mesmo partilhando da rejeição às normas sociais, as normas endógenas não eram suficientes. Assim, o grafite era formado de uma necessidade pelo impacto causado não mais por meio da repetição exaustiva da assinatura, mas pela elaboração da peça, colorida, acompanhada de figuras da cultura pop e impressas nos vagões do metrô, que circulavam por toda cidade. Com essa estratégia, a repetição dava-se pela circulação do metrô e como sua passagem pelos bairros era rápida, o desenho deveria chamar suficientemente atenção para se destacar na paisagem urbana tão transitória.

Figura 45 - Grafite United Artists

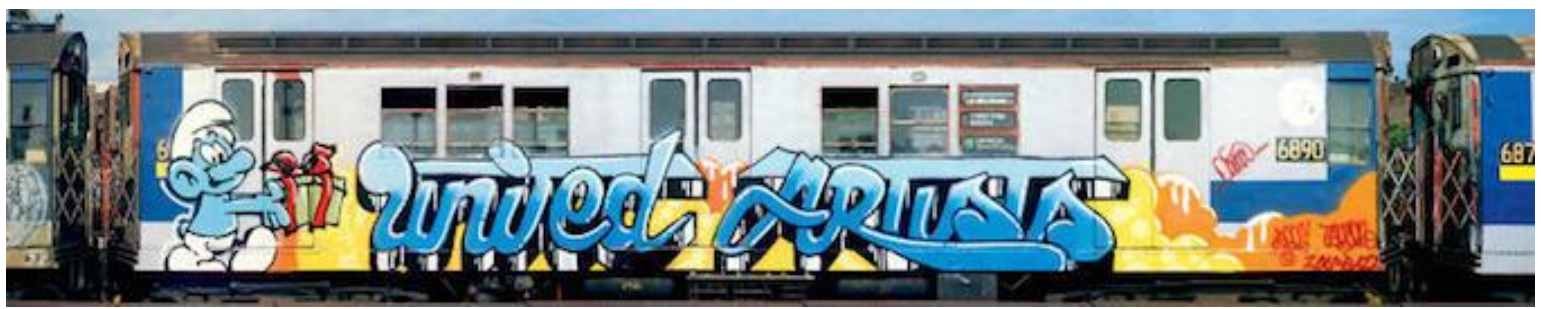

(CHALFANT; JENKINS, 2014, p. 61)

A inovação endógena determinante marca mais uma vez o surgimento de mais uma modalidade. $\mathrm{O}$ valor saturado e as normas endógenas extenuadas na etapa da instauração possuem uma resolução acelerada e novas normas são criadas para ajustarem-se ao desejo de reconhecimento. Porém encontra-se nas normas artísticas um meio eficaz para desenvolver as normas endógenas. A originalidade começaria a reger essa nova produção, ignorada completamente pelo mercado de arte. Uma mistura átona entre as normas endógenas da tag/throw-up e as normas artísticas, somada a uma manutenção da triagem tônica das normas sociais, gerariam as normas endógenas do grafite.

Com o passar do tempo, a modalidade estabelece-se e exclui toda e qualquer interferência de outras normas, inclusive as artísticas, que serviram somente para formar as normas endógenas do grafite. Essa inicial triagem tônica das normas criadas 
em prol de sua concentração, perde intensidade e abre caminho para a inauguração de novas normas, pois as determinações de "pureza" do grafite já não refletiam os valores de reconhecimento.

Portanto, o grafite originário dos anos de 1970 avistou nas normas artísticas uma possibilidade de mistura com as normas endógenas da tag/throw-up, preservando a triagem de seus valores em detrimento das normas sociais, que impediam seu reconhecimento devido ao conflito de valores. Porém, ao longo do tempo, essa intensidade na formação das normas do grafite vai diminuindo e abre espaço para outras possibilidades. O grafite segue o mesmo caminho das modalidades anteriores, porque tria suas próprias normas sem considerar o engessamento normativo que desconsidera em parte o valor reconhecimento.

Por exemplo, o tamanho, o lugar e o estilo da piece fundamentam o grafite, que tem como referência a triagem das normas sociais, contudo, a mudança de suporte, o desenvolvimento da técnica e a institucionalização chocam-se com as determinações do grafite e alinham-se às normas artísticas, mais interessada na elaboração pictórica e na utilização do espaço como integrante da obra, que na pura transgressão social do espaço. Dessa forma, o grafite encerra-se em suas normas e abre caminho para a formação da arte urbana. As normas do grafite preservam-se e sua associação ao movimento do hip-hop, que partilha dos mesmos valores de transgressão das normas sociais, contribui para a manutenção de suas normas.

\subsubsection{ARTE URBANA}

Os valores de reconhecimento do grafite encontram nas normas artísticas uma forma mais abrangente de exploração do espaço e da plasticidade, originadores da arte urbana. Menos preocupada em transgredir as interdições sociais que impactá-la, essa vertente do grafite elege a mistura tônica com as normas artísticas para dar continuidade aos seus valores de concentração. Em sua instauração, a saturação dos valores e a extenuação das normas do grafite provocam, no regime de resolução, uma 
integração das normas artísticas em direção à conformidade. A inovação endógena progressiva determinaria esse processo, pois valores e normas adequam-se lentamente.

Figura 46 - Keith Haring em sua obra pela foto de Annie Leibovitz

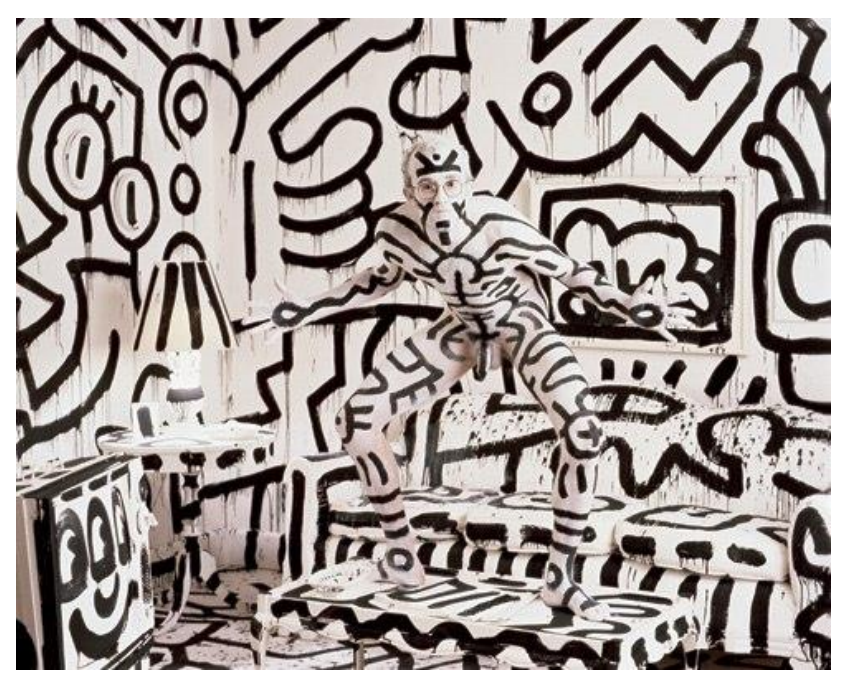

(LEIBOVITZ, 2016)

A absorção do grafite pelo mercado de arte incentivou grafiteiros a transpor suas pieces para as telas e artistas a apropriarem-se do grafite em suas obras. Essa dupla direção do grafite nos museus e da arte contemporânea nas ruas forma a arte urbana, cujo desenvolvimento gradual estabeleceu uma linguagem própria. Com isso, o uso do espaço pela arte urbana é feito sob diversas formas, partindo da pintura mural, da tipografia e da transgressão social, herdadas pelo grafite, a arte urbana expande-se e diversifica seus suportes, como instalação, escultura, tapeçaria, vídeos, fotos e performances; para deixar de ser produto da triagem de um grupo específico e misturarse sob os horizontes da arte contemporânea.

Figura 47 - Tag de Phase 2

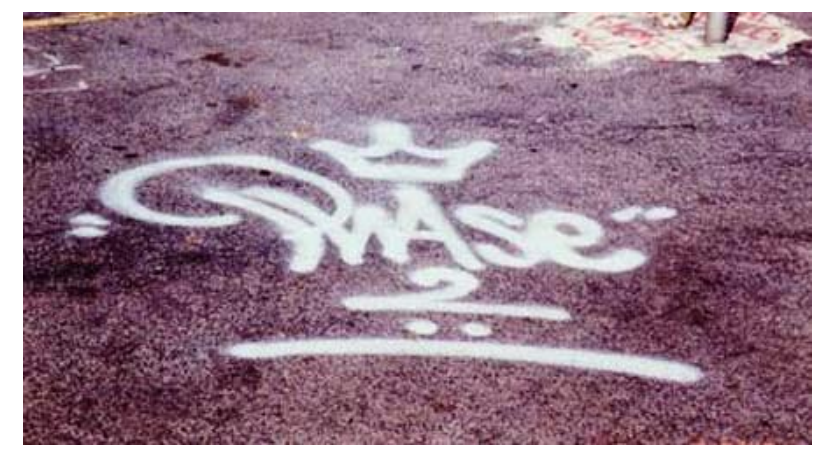

(SUBWAY OUTLAWS, 2016) 
Figura 48 - Throw-up de Phase 2

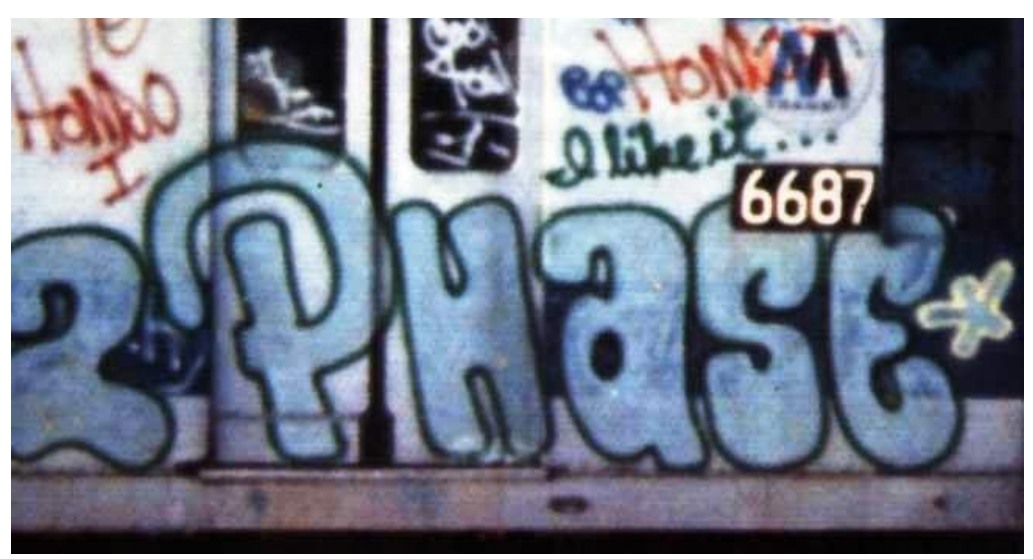

(ASPECTO URBANO, 2008)

Figura 49 - Arte urbana, quadro, de Phase 2

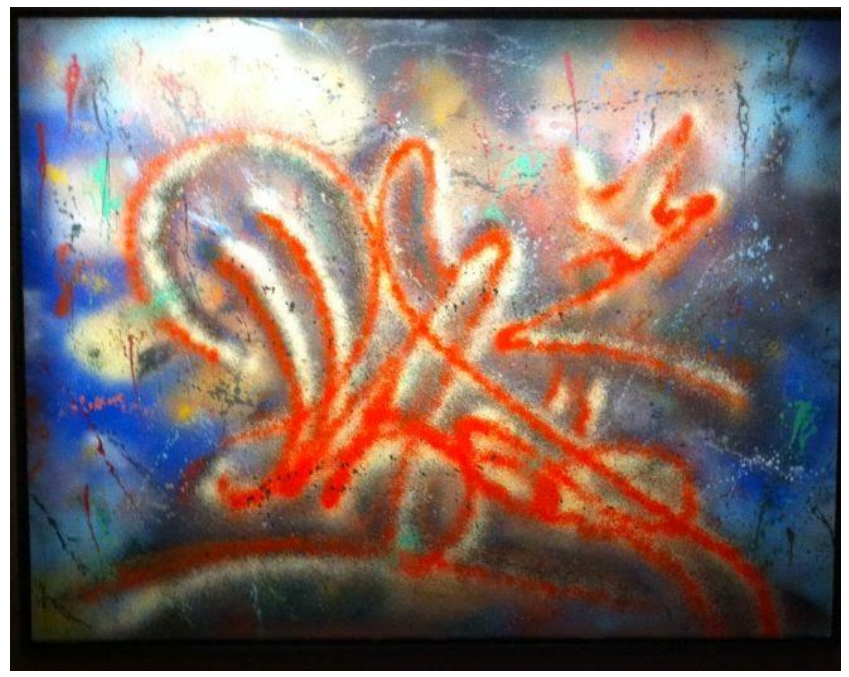

(PINACOTHÈQUE DE PARIS, 2015)

Por exemplo, a obra de Phase 2 percorre várias modalidades das inscrições urbanas, pois na busca pela autenticidade que lhe daria destaque, o artista criou estilos como a bubble letters e foi o primeiro a desenvolver uma master piece (obra-prima), na qual fundo e figura são igualmente elaborados plasticamente (CASTLEMAN, 2012, p. 87). A trajetória de Phase 2 confunde-se com a própria história das inscrições urbanas. Sua constante inovação acompanha as triagens e as misturas realizadas entre as normas endógenas de cada modalidade, sociais e artísticas.

Embora a arte urbana tenha deixado de priorizar as normas sociais na constituição de suas inovações, há ainda certa preservação da triagem encontrada nas normas do grafite. No entanto a arte urbana propiciou maior reflexão sobre o 
fenômeno da intervenção urbana e por conta dessa abordagem, houve aceitação social, que facilitou o desenvolvimento da prática. A arte urbana usa a transgressão do espaço público para promover um diálogo sobre seu uso, o grafite e a pichação dependem da transgressão para existir.

Da mesma maneira que o grafite dos anos de 1970, com sua triagem tônica, cedeu espaço para o desenvolvimento da arte urbana, perdendo sua intensidade, não se descarta a possibilidade de a arte urbana converter a mistura de escolhas enunciativas em triagem favorecedora de suas normas endógenas, porém, a inserção da pichação no campo da arte urbana parece afirmar a valorização da mistura de todas as modalidades de inscrição urbana com as normas artísticas.

\subsubsection{PICHAÇ̃̃O}

Expressão típica das inscrições urbanas no Brasil, a pichação pode ser ligada originalmente à tag pela marcação territorial, pela repetição de uma mesma assinatura, pela transgressão do espaço público e pela busca de fama dentre seus pares. No entanto a tag era menos elaborada esteticamente, o uso do spray ou tinta não era fundamental, já que poderia ser feita com um pincel atômico, e a qualidade do espaço perdia relevância para a reprodutibilidade da assinatura - espalhar a tag era mais importante que o lugar onde ela era feita.

A tag evoluiu para o grafite por meio de sua singularização no plano da expressão, mas perdeu sua ligação com a prática original devido ao uso da cor, à inserção de figuras, à ausência de repetição, à escolha criteriosa do espaço etc. Sua fama passou a ser construída na habilidade de execução de cada piece e não mais pelo espalhamento de uma única assinatura. Sob essa perspectiva, a pichação parece ter realizado esse percurso evolutivo da tag com maior coerência, apesar de a tag não ter sido adotada no Brasil no período de instauração das inscrições urbanas (anos de 1980).

Já a pichação compartilha dos valores de reconhecimento das inscrições urbanas e possui normas similares às tags, porém articula-se de um modo diferente. 
Embora a reprodutibilidade de uma mesma marca, o uso da linguagem verbal e a transgressão do espaço urbano aproximem a pichação da tag, sua elaboração estética e o modo de exploração da cidade individualizam a pichação como uma performance exclusivamente brasileira.

Figura 50 - Pichação Lixomania

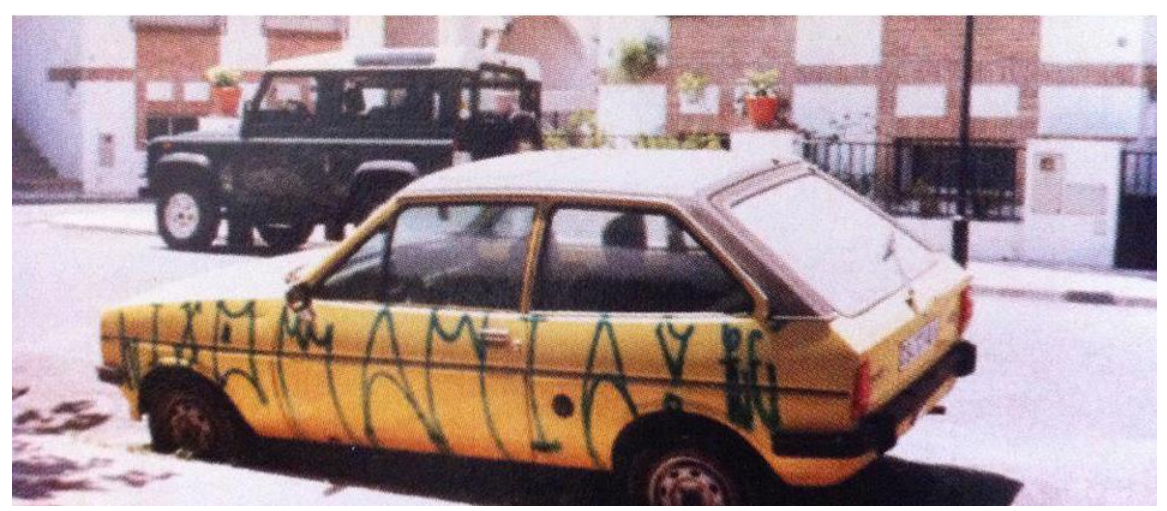

(BESIDE COLORS, 2011)

Ao criar suas próprias regras, por inovação endógena determinante, a pichação excluiu as normas sociais e artísticas e afastou-se dos recém-estabelecidos movimentos grafite e arte urbana. Seus valores impuseram uma adequação normativa, fechada cada vez mais em si mesma, provocando um discurso desfavorável a sua existência. Não obstante, a pichação fixou-se como um fenômeno permanente, invadiu as cidades com suas arriscadas escaladas urbanas, desenvolveu uma complexa tipografia e apartou os desconhecedores de suas regras.

Sua tipografia representa esse autoencerramento, que rebusca intensamente os caracteres da escrita verbal levando à minimização de seu conteúdo. A importância está no reconhecimento pictural da assinatura, não no significado da palavra. A escolha de "falar somente para os seus" provoca sua associação à marginalidade, cujo rótulo é alimentado pelo próprio discurso da pichação, seja pela escolha de palavras disfóricas para formar o picho, como Vermes, Cripta, Sustos etc; seja pelo seu modo de apropriação do espaço.

Durante os anos de 1990, a pichação esteve associada diretamente à criminalidade, enquanto que o grafite e a arte urbana passaram a gozar de maior reconhecimento social, talvez por isso a pichação foi tomada como objeto de análises sociológicas durante muito tempo. No entanto, nos anos 2000, começou-se a 
considerar a pichação como um movimento artístico criador de uma sofisticada tipografia. Sua impressão no espaço público por meio de performance inovadora, espécie de parkour, é percebida pela promoção de uma reflexão sobre a utilização do espaço público e privado nas metrópoles.

A inserção no mercado de arte pode ser vista pela participação de obras de pichação no circuito artístico, como na exposição Né dans la rue (2009) da Fundação Cartier em Paris, na Bienal de São Paulo em 2010 ou na Bienal de Berlim em 2012. Observa-se uma tendência à inovação exógena progressiva, pois a mudança seria conduzida pela absorção da pichação pelas normas artísticas provindas da arte urbana. A pichação seria "domada" pelo mercado de arte e seria ajustada a suas normas. Apesar de seguir essa direção, ainda há episódios que mostram o conflito dessa mistura. Como na Bienal de Berlim em 2012, onde os pichadores convidados a fazer um workshop revelaram ao público alemão a essência da prática, pichando ilegalmente uma igreja tombada pelo governo.

Figura 51 - Pichação Cripta em Paris

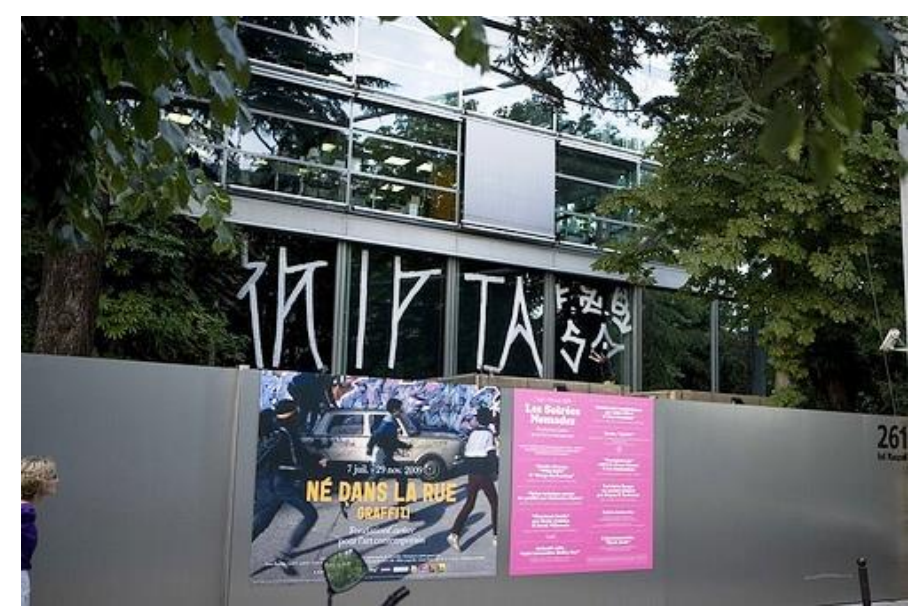

(CRIPTA, 2013)

De forma similar à inserção do grafite em galerias, a pichação é incorporada às exposições, sem mediação. Verifica-se na pichação de Cripta, ou Djan Ivson Silva, uma adequação estética de suas peças tipográficas a espaços autorizados, corroborando a hipótese da formação de pichação artística. O trabalho de Cripta participou desse processo de aceitação da pichação no mercado de arte, integrando as 
Bienais e a exposição na Fundação Cartier, e parece seguir em um aprimoramento da linguagem da pichação via arte contemporânea.

Essa potencial modalidade ainda é muito recente para ser definida no percurso das inscrições urbanas. Até porque a inserção de uma nova norma na história das inscrições urbanas, mesmo que prevista, pode produzir um rearranjo no sistema e por isso, seria prudente acompanhar seu desenvolvimento ao longo do tempo para verificar seu estabelecimento, ou melhor, sua etapa de resolução. Ao que parece, a mistura das modalidades de inscrição urbana e das normas artísticas ocorreu de tal modo ao longo da história, que se produz uma espécie de lei, na qual toda modalidade de inscrição urbana, de certa forma, acaba sendo integrada pelo mercado de arte e com a pichação não seria diferente.

\subsubsection{GRAPICHO}

Além de a potencial pichação-arte aparecer como uma nova modalidade por meio da integração com as normas artísticas; outra modalidade encontra-se já consolidada na história das inscrições urbanas: o grapicho, que é resultante da mistura entre as normas endógenas da pichação e do grafite.

Feito com o mesmo estilo tipográfico do picho, o grapicho aumenta o espaço ocupado pelas letras através do uso de cores e de figuras acompanhando a escrita. Além disso, o fundo na pichação é constituído pelo suporte e o picho é destacado como figura, no grapicho, um fundo construído pela pintura destaca a figura, o que cria volume à obra. A reprodução da obra no grapicho nega as normas da pichação para afirmar as normas do grafite, cuja elaboração da obra tem prevalência sobre sua repetição. Alcançam-se, então, os valores de reconhecimento pela demonstração das habilidades artísticas do enunciador. 
Figura 52- Grapicho, Naldo

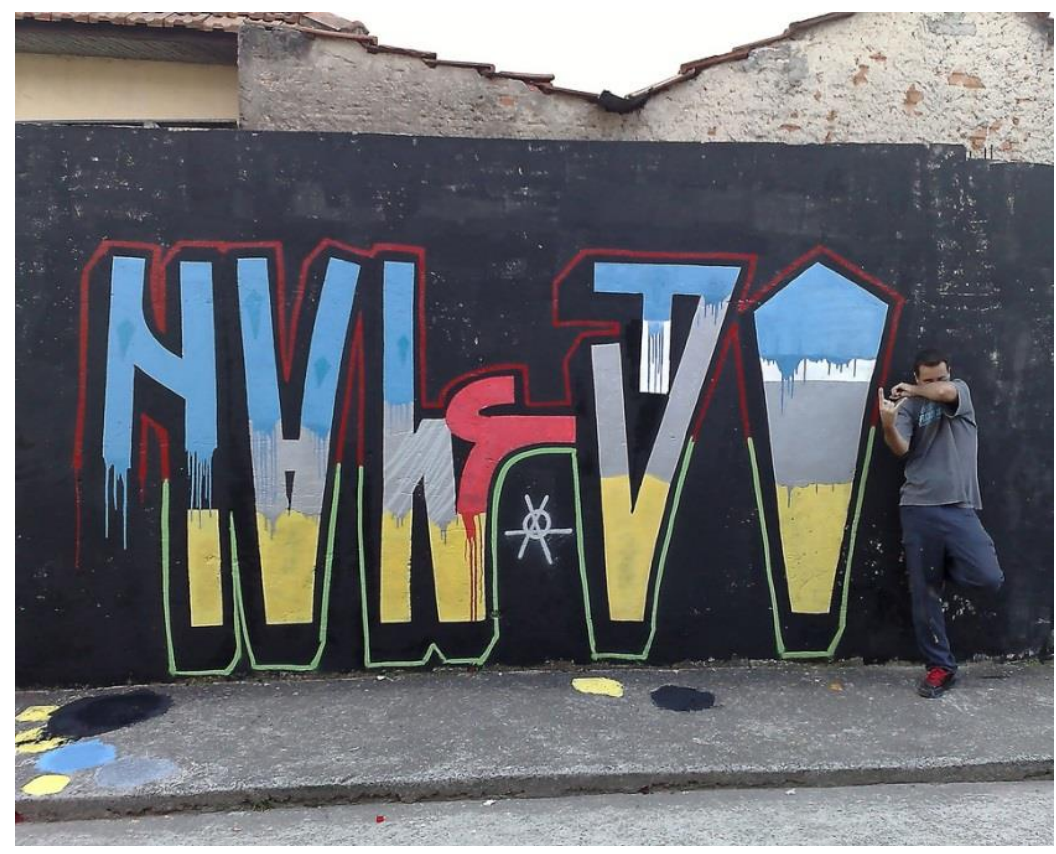

(BESIDE COLORS, 2011)

Ambas as modalidades compartilham os princípios de exclusão às normas sociais, mas somente o grafite abriu-se para a mistura com as normas artísticas, mesmo que tenha sido somente para estabelecer suas próprias normas, que a partir de então rechaçou qualquer possibilidade de contato com outras modalidades. A conformidade no grafite e na pichação seguiu pela manutenção da triagem de suas próprias normas, ou seja, eles assemelham-se por seu encerramento normativo.

No entanto uma mistura entre as duas normas foi formada pela saturação normativa e pela redução dos valores. Diferentemente das outras modalidades, em que o surgimento de uma nova norma faz com que parte do grupo formador dessa nova norma diminua sua produção na norma anterior e passe a considerar somente a recém-modalidade, caracterizando uma extenuação de valores em relação àquela norma. No grapicho, o grupo formador dessa nova modalidade mantém sua prática de pichação normalmente. Vale ressaltar que o grapicho parte da pichação e não do grafite, raramente será visto um grafiteiro fazendo grapicho. Dessa forma, considerase que os valores de reconhecimento foram reduzidos e não extenuados.

$\mathrm{Na}$ etapa de resolução, ocorre uma inovação exógena imediata, em que os valores reduzidos efetivam um percurso ascendente acelerado para entrar em conformidade com as normas. As escolhas enunciativas pela mistura entre as normas 
endógenas da pichação e as normas exógenas do grafite marcam esse tipo de inovação. Essa mistura é indiretamente uma abertura da pichação para as normas artísticas, já que o grafite as absorveu em suas normas. Inicia-se com o grapicho uma tomada de posição em direção ao impacto da obra única, mas sem deixar de lado a proliferação exaustiva da mesma assinatura, cujo devir pode estar na pichação-arte.

Assim, o modelo apresentado prevê a possibilidade de mistura e triagem entre normas sociais, artísticas e normas endógenas resultantes de misturas anteriores. A provável inovação exógena da pichação-arte parece confirmar a validade da proposta na análise das inscrições urbanas, mas sabe-se da instabilidade de qualquer afirmação sobre um fenômeno que não propicia a segurança da distância histórica. 


\section{RELAÇÃO ENTRE OS PLANOS NAS INSCRIÇÕES}

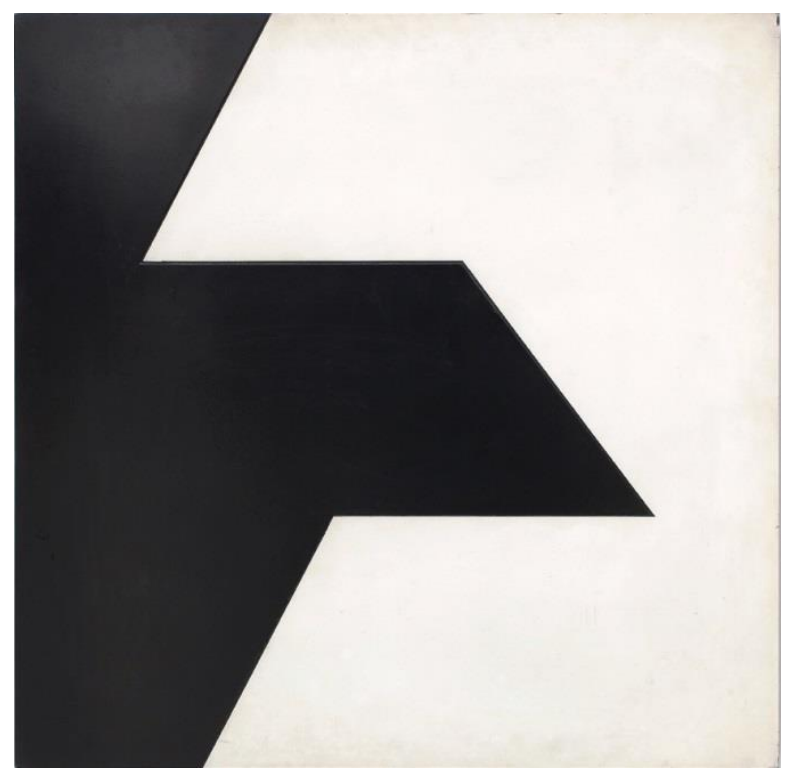

Lygia Clark 
O percurso desenvolvido na história das inscrições urbanas apresenta dois pontos fundamentais, que são definidos pela prática estabelecida nas cidades de Paris e Nova Iorque. Como foi observado, o grafite político de Paris tinha características próprias que foram seguidas ao longo das décadas, tornando-o uma referência. Do mesmo modo, o célebre grafite de Nova Iorque definiu seu estilo e influenciou as inscrições urbanas no mundo inteiro.

Ao longo da história das inscrições urbanas, percebe-se uma variação de intensidade no uso dos planos da linguagem, pois do lado estadunidense há uma ênfase no plano da expressão e no lado francês uma valorização do plano do conteúdo. Mesmo que haja uma relação interdependente entre os planos, unidos pela função semiótica, verifica-se que cada modalidade de inscrição urbana articula os planos de modo singular, produzindo suas especificidades. Assim, ao investigar como os planos da linguagem são relacionados nas vertentes de Paris e Nova Iorque, seria possível obter invariantes estilísticas que auxiliariam na análise das modalidades subsequentes.

Hjelmslev (2006) propõe que a língua, e consequentemente outras semióticas, é constituída de um plano do conteúdo e um plano da expressão, cada plano é formado por forma e substância, ou seja, há uma forma e substância do conteúdo e uma forma e substância da expressão. Partindo da prevalência da forma sobre a substância, o autor dinamarquês propõe um ponto de vista linguístico sobre os signos, pois somente pela forma chega-se à substância, que pode ser estudada por outras ciências, como a Fonética para a substância da expressão e a Semântica para a substância do conteúdo verbal.

Resumidamente, no caso do plano do conteúdo, os sentidos são segmentados pela forma do conteúdo resultando em conceitos (substância do conteúdo). Isso significa que a forma precede a substância. Todas as culturas estão expostas ao mundo perceptivo, porém, cada língua enforma esse sentido de modos diferentes. Esse recorte do contínuo perceptivo criaria forma e substância, que são realizadas paradigmaticamente ou sintagmaticamente.

Por exemplo, na percepção de gênero, a língua portuguesa divide seu paradigma em duas formas, masculino e feminino, a língua alemã estende essa divisão em três gêneros, masculino, feminino e neutro; e o inglês não apresenta distinção. Em uma breve comparação dessas três línguas modernas, observam-se, no português, os 
sintagmas nominais o menino e a menina, pertencentes aos gêneros masculino e feminino; que se desdobram em formas diferentes no alemão; der Junge ou der Bub (o menino) e das Mädchen (a menina), respectivamente, masculino e neutro, já que o equivalente em alemão, conservando o gênero feminino, poderia ser traduzido por die Jungfrau (a donzela ou a virgem), no entanto, esta forma já abrange um campo diferente na substância do conteúdo, e por fim, no inglês, the boy (o menino) e the girl (a menina), a distinção de gênero do sintagma nominal não é pertinente.

O mesmo ocorre na parte sintagmática do conteúdo. Os exemplos acima mostram que um ponto sintagmático em comum a essas três línguas é o uso do artigo anteposto ao substantivo e separado deste. No entanto, nas línguas nórdicas, como no dinamarquês, no sueco e no finlandês, o uso do artigo definido é posposto em relação do substantivo e unido a ele (DOCKHORN, 2008). Assim, no dinamarquês, o artigo de gênero comum en (Utrum), correspondente ao masculino e feminino, ao associar-se ao substantivo finger (dedo) produz a forma fingeren (o dedo) ou o artigo de gênero neutro et (Neutrum) forma kysset (o beijo), ao juntar-se à substantivo kys (beijo) (APRENDER LÍNGUAS, 2016).

Cada língua "recorta" esses sentidos de modos específicos e, ao fazê-lo, carrega consigo conceitos estritamente ligados a essa ação de decupagem semiótica. É evidente que, apesar de diferentes, as línguas possuem formas equivalentes, não iguais, na apreensão do sentido.

A expressão semiótica, assim como o conteúdo, é constituída por forma e substância. No paradigma da expressão (classe), por exemplo, o português diferencia os fonemas [b] e [v], o que já não acontece no espanhol, que tem no [b] maior ocorrência na fala, mas sem o diferenciar do $[\mathrm{v}]^{36}$. Isso ocorre porque o português delimita e separa no contínuo sonoro a articulação oclusiva bilabial surda /b/ da fricativa labiodental sonora /v/ e o espanhol mantém-nas sem distinção significativa (RAE, 2005).

$\mathrm{Na}$ cadeia expressiva, encontra-se o mesmo princípio de delimitação da forma sobre o sentido. Retomando a comparação entre as línguas modernas, o português não

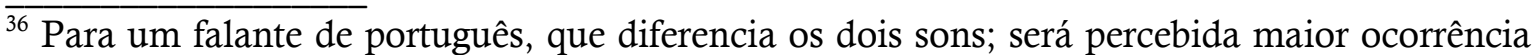
do fonema [b] na língua espanhola. Por exemplo, na palavra "vinho" ['bi.no], o falante poderia pronunciar ['vi.no] e não haveria diferenciação para o ouvinte espanhol, apesar de o uso privilegiar a primeira forma.
} 
permite a sequência /pf/, ou seja, a ocorrência da consoante /f/ após o /p/ na mesma sílaba. Contudo, no alemão, essa construção faz parte do sistema, como em Pfeffer (pimenta) ou Pfütze (poça). Dessa forma, cada eixo de análise - a paradigmática e a sintagmática - é composto por um plano da expressão e um plano do conteúdo:

Todo texto, um processo, é inicialmente divisível numa linha da expressão e numa linha do conteúdo. Os paradigmas, classes do sistema, têm uma face da expressão e uma face do conteúdo. Para designar a linha e a face por um mesmo termo, Hjelmslev cria as expressões "plano do conteúdo" e "plano da expressão". Elas não são sinônimos perfeitos dos vocábulos "significado" e "significante", pois contêm uma dimensão formal, que não estava presente nos termos saussurianos, já que, na obra do linguista de Genebra, o significado e o significante eram definidos substancialmente, e ao mesmo tempo elas comportam uma dimensão sintagmática e uma paradigmática, que também estavam ausentes da concepção de Saussure (FIORIN, 2003, p. 37).

A manifestação resultante da relação plano do conteúdo e plano da expressão é a língua (na paradigmática) e o texto (na sintagmática). A função semiótica é a responsável pela junção dos planos, que são indissociáveis, pois é por meio de determinada expressão que o conteúdo se manifesta e é pelo conteúdo que a expressão ganha sentido. Com isso, a teoria semiótica cria um método baseado na semiótica verbal, que explica a formação do plano do conteúdo, cuja pertinência seria independente da substância veiculadora. Esse método denomina-se percurso gerativo do sentido.

Embora o percurso gerativo do sentido tenha passado por atualizações, ainda mostra-se eficaz e não foi substituído. Ele é o ponto de partida para as reflexões da teoria semiótica clássica, estabelecida por Greimas (1983). Já o plano da expressão não possui o mesmo tipo de abordagem. Vários autores trataram do tema, mas sem estabelecer o mesmo "consenso" metodológico do percurso gerativo. Devido à diversidade de substâncias da expressão, como o som para a semiótica verbal e musical ou a plasticidade para a semiótica plástica e também para semiótica verbal, torna-se até o momento questionável a produção de um método semelhante ao percurso gerativo para o plano da expressão.

Para começar a enfrentar essa diversidade metodológica, a relação entre plano do conteúdo e plano da expressão no nível textual pode ser abordada por meio das 
funções utilitária e estética da linguagem. Na função utilitária, a relevância está no plano do conteúdo e, na função estética, o plano da expressão ganha destaque. É preciso salientar que os dois planos são indissociáveis, tanto uma função quanto a outra revelam uma estratégia discursiva para enfatizar um dos planos, sem eliminar o outro. Paul Valéry, em seu ensaio Poesia e pensamento abstrato (1999, p. 93), faz uma reflexão sobre a diferença do valor dado à linguagem - ora focada no plano do conteúdo, ora focada no plano da expressão:

Eu peço fogo a vocês. Vocês me dão fogo: vocês me compreenderam. Mas ao pedir fogo, vocês puderam pronunciar essas poucas palavras sem importância com uma certa entonação e um certo timbre de voz - com uma certa inflexão e uma certa lentidão ou uma certa precipitação que pude observar. Compreendi suas palavras, já que sem mesmo pensar, estendi-lhes o que pediam, o fogo. E, contudo, eis que o assunto não acabou. Coisa estranha: o som e como que a imagem de sua pequena frase reaparecem em mim, [...] repetindo essa pequena frase que quase perdeu o sentido, que deixou de servir e que, no entanto, quer viver ainda, mas uma vida totalmente diferente. Ela adquiriu um valor; e adquiriu-o em detrimento de seu significado finito [...] (VALÉRY, 1999, p. 200).

O autor francês trata da mudança da função utilitária para a função estética no texto. Primeiramente, a frase atinge seu objetivo, o fogo, sem considerar o modo como foi pronunciada, ressalta-se o plano do conteúdo. Em seguida, a importância dada ao som, ao andamento e ao timbre da voz liga-se ao plano da expressão, atenuando seu significado. Só assim a frase persiste na mente do autor, devido à forma utilizada para expressá-la.

A função utilitária da linguagem situa-se no falar cotidiano, nas mensagens imediatas e pragmáticas, já a função estética da linguagem destaca o plano da expressão recriando formas para intensificar ou modificar o conteúdo a ser transmitido. Os discursos artísticos empregam frequentemente esse tipo de função. Para compreender como os planos alinham-se em determinadas semióticas, tomam-se os conceitos de semiótica monoplana e biplana de Hjelmslev (2006).

Para o autor dinamarquês, há sistemas que possuem uma correspondência unilateral entre partes dos planos, ou seja, a substância do conteúdo associa-se a uma expressão. Esses são chamados de sistemas de símbolos, pois são interpretáveis, devido à substância, mas não possuem forma de conteúdo. Pensar em uma relação de conformidade entre os planos geraria o termo de semiótica monoplana, porém, como 
a não conformidade entre os planos está no cerne da estrutura semiótica, o termo sistema de símbolos é o mais adequado.

Por exemplo, a pomba branca simboliza a paz na mitologia judaico-cristã, a balança e seus pratos são o símbolo da justiça e as onomatopeias representam sons específicos nas línguas naturais, como o "Wau-Wau" para o latido do cachorro na língua alemã, ou o "splash" do inglês para designar um impacto envolvendo algum líquido. Em todos esses casos, o sentido está ligado estritamente à sua expressão, termo a termo, a pomba branca não possui outro sentido além da ideia de paz; dessa forma, não se pode chegar a elementos mínimos (figuras) e comutá-los para formar outros símbolos, a pomba branca vai sempre significar paz e se alterarmos qualquer elemento, ela deixa de ter sentido enquanto símbolo.

Já nas semióticas biplanas, essas, sim, sistemas semióticos, não há conformidade entre os planos, porque eles são estruturados de forma independente. $O$ plano da expressão, na semiótica da língua natural, pode ser analisado em elementos mínimos, traços distintivos, e o plano do conteúdo em semas. A troca dos fonemas /b/ por /m/, no sintagma /bola/, não gera um signo "sem sentido", apenas uma mudança de conteúdo, /mola/, devido a substituição de um traço oclusivo /b/ por nasal $/ \mathrm{m} /$ e esses mesmos fonemas integram outras formas como $/ \mathrm{bico} / \mathrm{e} / \mathrm{mico} / \mathrm{O}$ conteúdo segue a mesma estrutura. O lexema /cadeira/, por exemplo, relaciona os semas /para sentar/; /com pés/; /com encosto/; /sem braços/, entretanto, ao alterar o sema /sem braços/ para /com braços/ cria-se outro lexema, como /poltrona/e assim, sucessivamente.

\footnotetext{
A condição que exige que se opere reconhecendo dois planos deve ser que, quando se tenta levantar os dois planos, não se possa demonstrar que os dois planos têm a mesma estrutura com relação unívoca entre os funtivos de um plano e os do outro plano. Expressaremos isto dizendo que os dois planos não devem ser conformes um ao outro (HJELMSLEV, 2006, p. 117).
}

Para tratar de sistemas que exploram a função estética da linguagem, a teoria semiótica desenvolveu o conceito de sistema semissimbólico. Com o mesmo princípio dos símbolos, esse recurso é empregado nos sistemas semióticos, que não permitem a total conformidade entre os planos, porém, admite-a entre categorias. Isso quer dizer que é possível estabelecer uma relação conforme entre categorias dos dois planos da 
linguagem, à moda simbólica. Uma categoria do plano do conteúdo liga-se a uma categoria do plano da expressão, geralmente, intensificando a apreensão do sentido.

$\mathrm{Na}$ semiótica verbal é comum encontrar esse tipo de recurso no discurso poético, por exemplo, no poema "lygia fingers" de Augusto de Campos (2014), no qual as categorias cromáticas e topológicas da dimensão visual cor quente $v s$. cor fria, cromatismo heterogêneo $v s$. cromatismo homogêneo e alto $v s$. baixo somadas às categorias fonéticas vocálicas da dimensão sonora anterioridade $v s$. posterioridade estão associadas aos conteúdos de conjunção vs. não conjunção do sujeito lírico com seu objeto de desejo, a mulher amada. Outras categorias do conteúdo que ingressam nessa rede semissimbólica são euforia vs. disforia, cuja relação é construída no discurso do poema pelos valores positivos associados à conjunção do sujeito com seu objeto e que são transformados em negativos pelo impedimento dessa união (PONDIAN, 2005).

Figura 53 - Poema Lygia fingers

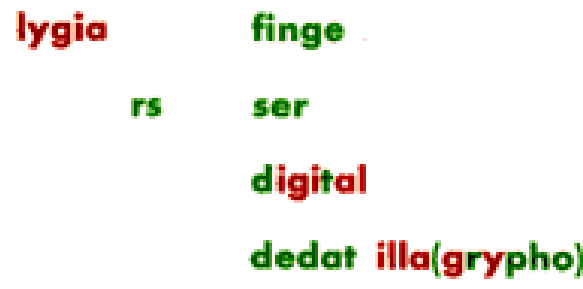

lynx lynx

assim

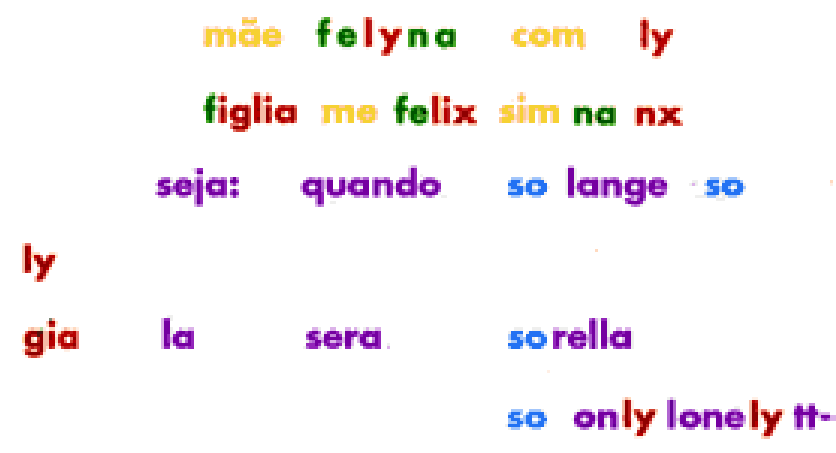

I

(CAMPOS, 1999) 
Dessa forma, a disposição cromática e topológica das letras no poema e a utilização de vogais anteriores e posteriores estão diretamente ligadas aos conteúdos juntivos e fóricos, logo, o enunciador por meio dos recursos linguísticos oferecidos pelas semióticas verbal e plástica cria seu próprio microuniverso simbólico contido em um poema.

Pondian (2005) argumenta que as categorias do plano do conteúdo empregadas para analisar o poema pertencem ao nível fundamental do percurso gerativo do sentido, entretanto, é possível que o semissimbolismo ocorra com categorias nos demais níveis do percurso gerativo do sentido. A função estética da linguagem marca os discursos artísticos, que empregam diversos recursos para alcançar o impacto no espectador. Como demonstra Fiorin (2008), as categorias do plano do conteúdo são encontradas nos três níveis do percurso gerativo e cabe ao analista compreender quais são as relações construídas no texto que são mais bem explicadas por seu método.

A função utilitária da linguagem encontra-se na transmissão de conteúdos e a função estética aproveita as potencialidades do plano da expressão para intensificar e até mesmo recriar os conteúdos a serem comunicados. Pelos conceitos de símbolo e de semissimbolismo da teoria semiótica, obtêm-se ferramentas analíticas pertinentes para descrever os textos em seu processo de produção do sentido. As balizas deixadas pela ciência da linguagem levam à investigação das modalidades de inscrições urbanas por meio da relação entre plano do conteúdo e plano da expressão.

\subsection{O ÚTIL E O ESTÉTICO NAS INSCRIÇÕES URBANAS}

As escolas de Paris e Nova Iorque diferenciam-se pelo modo que lidaram com os planos da linguagem. Enquanto a função utilitária era valorizada pelas inscrições urbanas parisienses, a função estética nutriu os grafites nova-iorquinos. Essa separação didática auxilia a entender a evolução das inscrições urbanas, já que inscrições com ênfase no plano do conteúdo são mais recorrentes no continente europeu, seja pelos projetos pioneiros de Ernest Pignon-Ernest, pelas inscrições políticas do Maio de 1968 ou pelo uso de figuras icônicas pop feitas por Blek le Rat, e inscrições com maior 
valorização do plano da expressão são encontradas no grafite nova-iorquino pela tag, pelo lettering e pelo grafite abstrato.

No entanto, como visto anteriormente, essa divisão dilui cada vez mais suas fronteiras com o passar das décadas e o que era uma marca regional passa a ser individual, ou seja, ainda se encontra essa divisão, mas em obras específicas, não em movimentos de grupos. Por exemplo, Banksy segue os preceitos estéticos de Bleck le Rat e Jeff Aerosol, pelo uso do estêncil e pelo traço de suas figuras, mas ele ganha destaque pela diversidade dos suportes, pela audácia das intervenções e, sobretudo, pelo conteúdo político sarcástico, com precedentes no Maio de 1968 em Paris. Por outro lado, Zezão explora as formas gráficas da linguagem verbal com uma paleta de cores restrita, uso preponderante do azul, para produzir uma arte urbana abstrata à moda de Nova Iorque.

A identificação dessas células caracterizadoras não diminui e nem restringe a multiplicidade dos trabalhos artísticos nas inscrições urbanas, apenas mostra uma tendência de valorização de um plano da linguagem. Evidentemente que há trabalhos que optam pelo equilíbrio entre os dois planos e o emprego do símbolo e do semissimbolismo poderia ser entendido como um dos recursos disponíveis para chegar a essa dupla intensificação. A obra de OSGEMEOS parece seguir por esse caminho, porque integra conteúdos ora políticos, ora oníricos, com um desenvolvimento estético consistente, principalmente na criação de texturas.

Apesar dessa fórmula didática, que oferece um panorama da história das inscrições urbanas, julga-se pertinente investigar com maior cuidado esses recursos, pois na simples definição de função utilitária e função estética, incluindo os conceitos de símbolo e semissímbolo, haveria particularidades nas inscrições urbanas relativas aos planos do conteúdo e da expressão. Para chegar a esse desenvolvimento, inicia-se com breves análises do emprego da função utilitária e estética da linguagem em obras de inscrição urbana.

Na célebre inscrição política brasileira "Abaixo a Ditadura", contra o Regime Militar instaurado a partir de 1964, nota-se que não há uma intensificação suficiente do plano da expressão seja ela plástica ou sonora, que interfira na função de comunicar conteúdos. Em termos rítmicos, trata-se de um hexassílabo com cesura na segunda sílaba, pois no português falado soa artificial não fazer a elisão do [ $\mathrm{Ju}]$ final com o artigo feminino. Tal ritmo não é muito comum em língua portuguesa, salvo 
quando está associado ao dodecassílabo. Uma aliteração com as oclusivas [b], [d] e [t] e repetição de três vogais [a], [i] e [u] nas duas palavras seriam o destaque no plano da expressão fonético.

Figura 54 - Inscrição Política no Regime Militar brasileiro

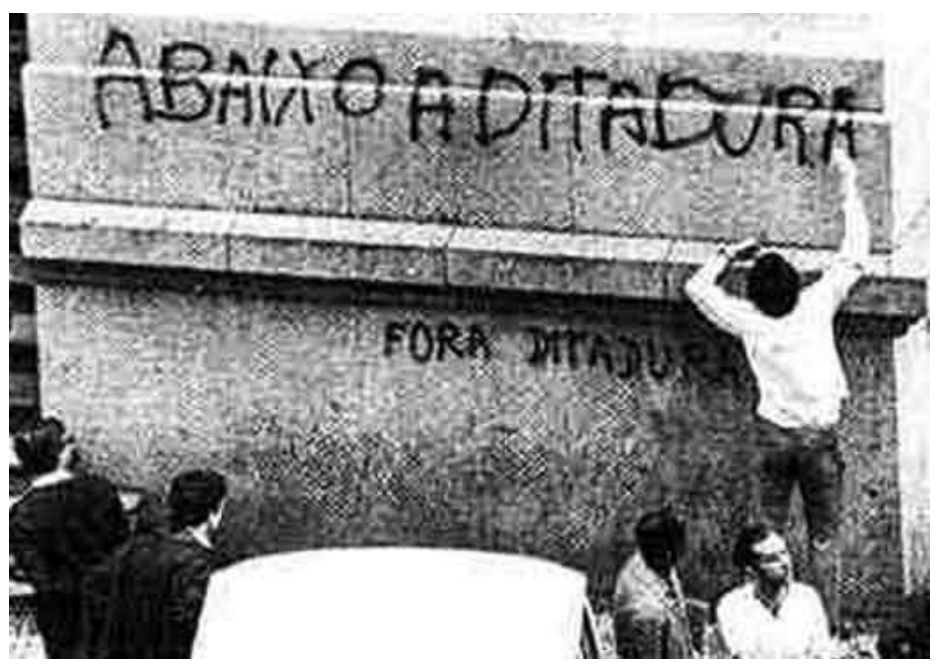

(RESISTENCIA ARQUIVO, 2014)

$\mathrm{Na}$ foto da inscrição política, não haveria qualquer exploração estética na tipografia ou no uso do espaço. As letras bastão, associadas a uma debreagem enunciva devido a seu uso discursivo, perdem sua marca de terceira pessoa ao serem escritas com formato arredondado, produzindo uma debreagem enunciativa, reforçada pela figura do sujeito que está no momento de inscrição do protesto ${ }^{37}$. O espaço é o da praça pública, lugar comum de debates políticos desde os gregos. Não se descarta a possibilidade de essa inscrição estar vinculada a uma estética política ou ser abordada por outros vieses, nos quais o plano da expressão tenha relevância, já que o ponto de vista faz o objeto. No entanto afirma-se a baixa intensidade do plano da expressão em comparação ao plano do conteúdo, que dá sentido aos elementos expressivos átonos.

A atonia dos recursos poéticos verbais e da elaboração tipográfica ganha sentido ao ser relacionada à função utilitária da inscrição. O espaço da praça pública interditava a liberdade de expressão e toda inscrição política era um ato de bravura, por isso, a inscrição tornou-se também um registro da performance, do ato. A

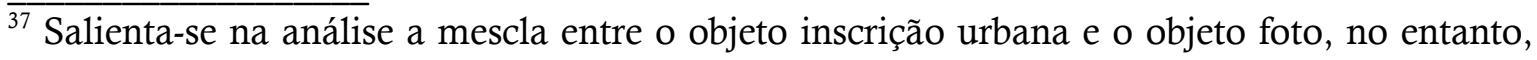
acredita-se que essa breve mistura está em prol da compreensão tipográfica da inscrição.
} 
comunicação dos conteúdos atenua as potencialidades expressivas e dirige o modo de realizá-las. O ato é conduzido pelo conteúdo da inscrição que dá voz a discursos contrários ao regime. "Abaixo a Ditadura" produz uma comunicação direta com o enunciatário, sem paradas no plano da expressão, para quiçá engajá-lo.

Nas inscrições políticas do Maio de 1968 em Paris, conquanto a maior exploração do plano da expressão, como no caso de c'est interdit d'interdire (é proibido proibir), que se destaca pelo eco da palavra / interdit/, pela repetição de nasais e oclusivas, pelo ritmo etc., a função utilitária marca ainda assim esse tipo de inscrição. Seguindo a mesma direção do protesto brasileiro, a ênfase da inscrição francesa no tema da proibição cria um jogo interessante de ideias, porque usa o próprio mecanismo da censura para neutralizá-la.

Indo mais além, esse recurso de interdição é colocado em contradição por ele mesmo, pois se é proibido proibir, isso a priori significa que deve haver liberdade, mas ao considerar a frase como uma interdição, o princípio de censura deve ser mantido, ou seja, é interdita a proibição de proibir, que, por sua vez, é uma proibição, logo, segue-se para mais uma nova proibição e assim sucessivamente. A espiral lógica elaborada pelo protesto põe em xeque o discurso censurador, já que proibir gera mais proibição, e o movimento estudantil lutava para acabar com essa prática. Por meio desse conceptualismo barroco, o conteúdo da inscrição ganha destaque. Essa exploração dos recursos sonoros da semiótica verbal, que não se encontra no exemplo do protesto brasileiro, alargaria os limites da função utilitária. Ou essa inscrição já seria considerada pertencente à função estética devido ao uso poético do conteúdo?

Nota-se que a relação entre as ênfases no plano do conteúdo ou no plano da expressão sobressai-se às delimitações dos termos. Há alterações de intensidade entre os planos que dificultariam sua identificação. Desse modo, o reconhecimento das intensidades em cada plano conduziria a uma gradação, cujos extremos seriam representados por categorias "puras" que seriam representadas pelas funções utilitária e estética e, na comparação das modalidades de inscrição urbana, surgiriam variações dessas funções. Antes de desenvolver essa linha de análise, prossegue-se com a verificação do uso da função estética da linguagem nas inscrições urbanas.

Destaca-se, então, o recurso do semissimbolismo na função estética da linguagem, em que o plano da expressão já não é somente um transmissor de conteúdos, mas está articulado para reforçá-lo e recriá-lo. Dessa vez, as inscrições 
nova-iorquinas são ressaltadas por sua produção marcada pela força do plano da expressão. A tag e o grafite são modalidades emblemáticas de Nova Iorque. Para tratar do semissimbolismo, recorre-se à inscrição do grafiteiro Bil Blast "Sky's the limit" (CHALFANT e PRIGOFF, 2009, p. 20-21):

Figura 55 - Sky's the Limit (1982)

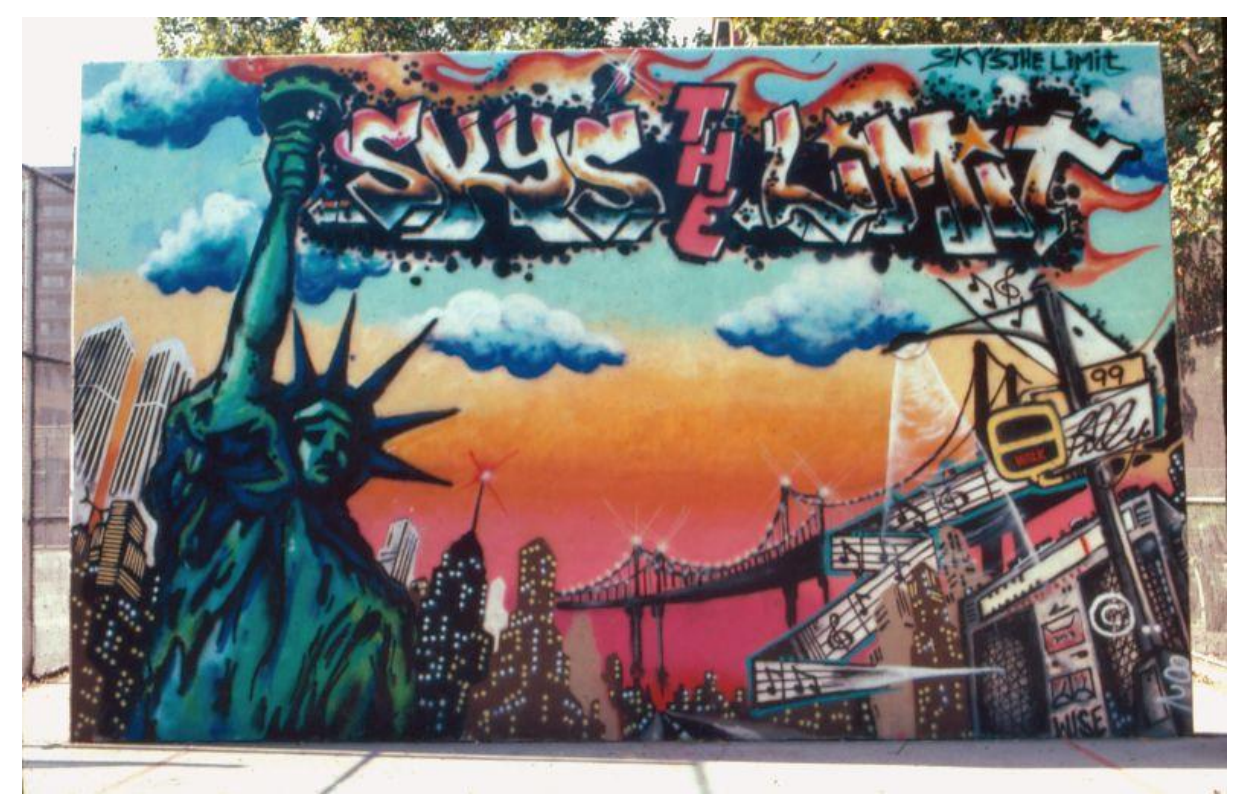

(CHALFANT; PRIGOFF, 2009, p. 20-21)

Em uma análise sucinta; feita para mostrar as relações semissimbólicas do grafite, destaca-se o nome da inscrição "Sky's the limit", cuja tradução literal para o português seria "céu é o limite". Essa expressão possui equivalência nas duas línguas e por isso está associada a conteúdos de difusão, ou seja, não há limites, mas a que ou a quem a ênfase nessa ausência de limites estaria ligada? Ora, ao verificar a prática do grafite na história das inscrições urbanas, traçada anteriormente, nota-se que o conteúdo da inscrição possui uma temática metalinguística. A completa difusão está associada à prática do grafite, que sofreu e sofre de uma contínua limitação por parte do poder público.

Esse enunciador/sujeito instaura na frase da inscrição seu objeto, a difusão, que pode ser associada ao suporte. A difusão das inscrições urbanas pelo uso indiscriminado do suporte chegaria, como apresentado na obra, a um grafite no céu, que realiza exatamente o conteúdo da frase para afirmar seus valores. Na articulação entre o plano do conteúdo e o plano da expressão, a cidade de Nova Iorque está 
disposta na parte inferior de forma concentrada e heterogênea, em oposição ao objeto de valor do sujeito/enunciador. Há uma sobreposição de figuras; prédios, ruas, uma ponte, uma boom box gigante com a forma de um edifício e arranha-céus que, acumulados no mesmo espaço, criam um efeito concentrador e multifacetado. Já na parte superior, a frase constituída de formas homogêneas sobre um céu amplo com nuvens dispersas traz um contraste em relação à parte inferior, assim como a figura da cidade em preto e marrom unida a um fundo rosa e laranja (representando o anoitecer?) são mais escuras se comparadas à parte superior, mais clara, devido às figuras do céu em azul claro e o fogo da tocha. Assim, uma correlação possível entre categorias dos dois planos seria ${ }^{38}$ :

Tabela 4 - Semissimbolismo na obra de Bil Blast

\begin{tabular}{c|c} 
Plano do Conteúdo & Plano da Expressão \\
\hline Difusão & Superior \\
Homogeneidade & Claro \\
\hline Concentração & Inferior \\
Heterogeneidade & Escuro
\end{tabular}

A figura da estátua rompe com essa relação categorial, pois está disposta tanto na parte superior quanto na parte inferior, seu verde em oposição ao preto e marrom da cidade é mais claro, porém, em comparação ao céu azul é escuro. A maior parte do quadro respeita linhas horizontais; mesmo os edifícios, que estão integrados na linha do horizonte. A estátua quebra com esse jogo simétrico, ela corta verticalmente as linhas horizontais e produz um contraste cromático no primeiro plano. Essa irregularidade pode estar vinculada ao conteúdo simbolizado por ela.

A absorção de categorias do semissimbolismo pelo monumento estadunidense atravessa o texto visual, sua base fixa na figura da cidade, contribuindo para a heterogeneidade da parte inferior, chega ao céu com sua tocha irradiando o fogo que engloba a frase-tema. Ao unir os dois planos, superior e inferior, a estátua poderia ser

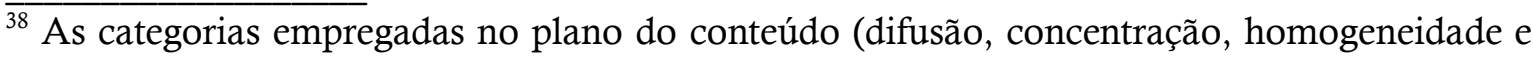
heterogeneidade) poderiam ser aplicadas igualmente no plano da expressão, porém, foram escolhidas outras categorias para fazer uma diferenciação mais evidente entre os planos.
} 
considerada um termo complexo em prol dos valores de liberdade que simboliza. No entanto os valores opostos, os de opressão, não possuem intensidade significativa ou pelo menos não possuem tanta evidência: por um lado a cidade ao fundo poderia tematizar essa opressão política do poder público contra as inscrições urbanas, por outro lado, a cidade é o espaço concentrado em que as inscrições urbanas tentam se difundir. Ambas as perspectivas poderiam estar em uma rede de relações criada pelo símbolo da liberdade no contexto das inscrições urbanas, mas somente a integração das categorias do semissimbolismo inicial poderia ser afirmada com segurança.

A estátua nova-iorquina seria posta para afirmar a difusão do grafite ou contrapor-se a valores de opressão, cuja interdiscursividade dependeria de um enunciatário competente a respeito das inscrições urbanas. Ambas as interpretações seriam possíveis. A figura vertical ofereceria uma liberdade de leitura sobre sua própria condição na obra, múltipla e difusa. Assim, Bil Blast (1982) oferece uma inscrição exemplar sobre a realização do semissimbolismo. As equivalências entre as categorias topológicas e cromáticas no plano da expressão e os conteúdos de difusão, concentração, heterogeneidade e homogeneidade contribuem para a identificação da função estética da linguagem.

Entretanto Lady Pink, uma das primeiras mulheres ou a primeira (como ela costuma reforçar) a participar do movimento de inscrição urbana em Nova Iorque desde o início da prática, conduz as análises a mais uma problematização desses termos estanques. Por meio de seu autorretrato, Lady Pink mostra o uso do recurso do semissimbolismo na produção de N.Y.

Apesar de tratar-se de uma tela, as características do grafite são mantidas. A temática e a figuratividade das ruas é preservada, porém, ligam-se a elas características típicas das artes plásticas, marcando a consolidação do período em que os grafiteiros são valorizados pelo mercado de arte. O suporte tela e o autorretrato são marcas dessa absorção do mundo das artes e o estilo do desenho, a mensagem verbal e as cores em uma linguagem pop concernem ao mundo do grafite. A mescla desses dois modos de fazer arte produz a arte urbana. 
Figura 56 - Autorretrato Lady Pink (1991)

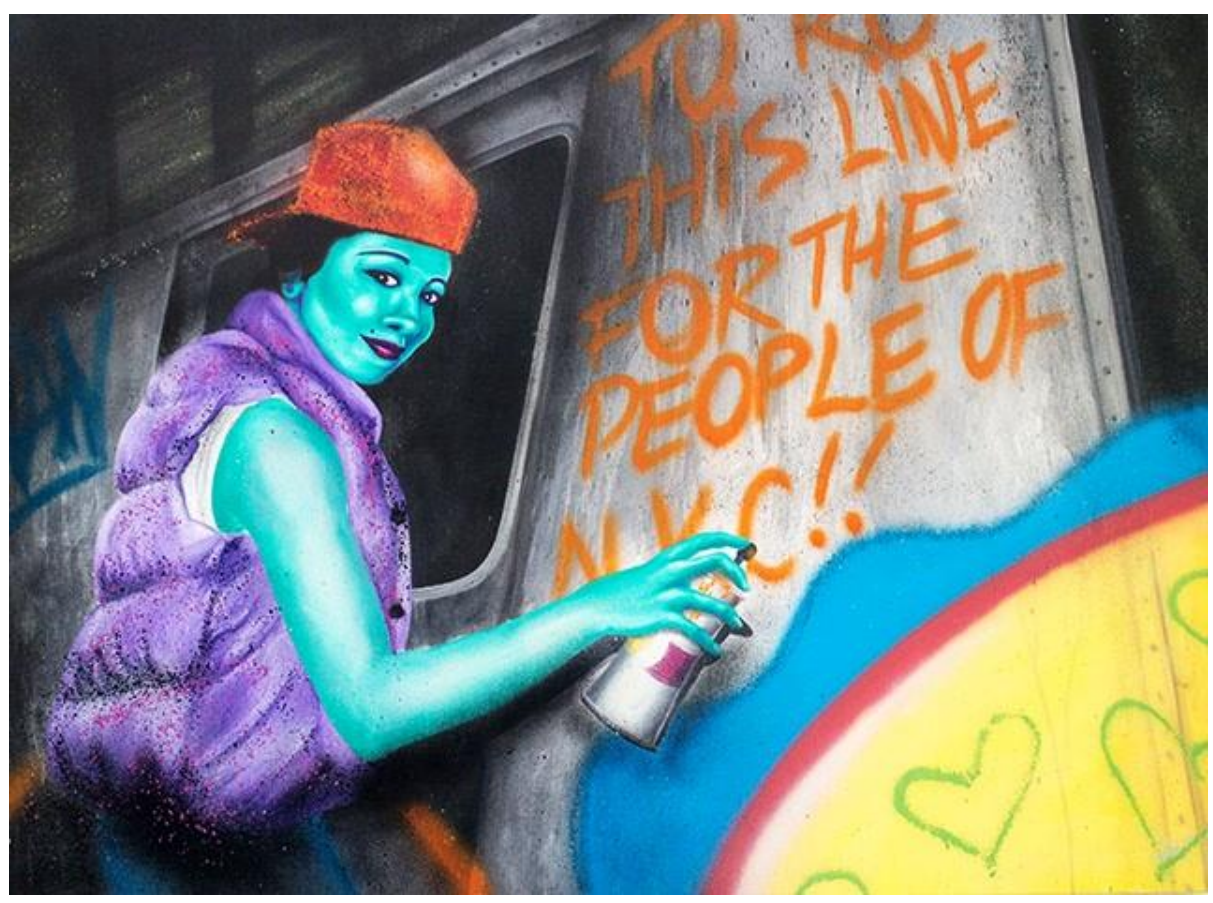

(PINACOTHÈQUE DE PARIS, 2015, p. 106-107)

O elemento mais representativo dessa mescla está no autorretrato, pois provém da prática das artes plásticas, mas ao mesmo tempo é integrada ao estilo grafite. A consolidação do grafite nova-iorquino institui um elemento estrutural: o nome do artista. Todo grafite é elaborado a partir de um nome, seja ele um apelido ou o nome de batismo, geralmente acompanhado de uma figura, de uma paisagem de fundo ou de ambos, porém há grafites que se concentram somente na sua exploração plástica. No quadro de Lady Pink, a identidade do artista não surge por meio de seu nome, mas, sim, por sua imagem, ou seja, o autorretrato preserva a prática de inserção de um elemento identitário pelas vias da arte institucionalizada ${ }^{39}$. Esse é um exemplo pertinente de arte urbana.

O quadro tematiza o ato de grafitar, pelo uso do spray, pelo suporte vagão de metrô e pela mensagem deixada ao povo de Nova Iorque, muito comum nos grafites de trem, em que os grafiteiros deixavam uma mensagem ao lado da peça constituída de nome e figura. Como mostra este grafite de Lee, cuja mensagem "grafite é uma arte

\footnotetext{
$\overline{39}$ Os elementos estritamente ligados à linguagem do retrato não serão abordados devido ao enfoque dado ao semissimbolismo, contudo, para um estudo mais profundo desse tema ver Dondero (2013).
} 
/ e se arte / é um crime, / deixe que Deus / perdoe a todos" é inserida pelo recurso do balão das HQs, neste exemplo, ligada à figura do pato Donald.

Figura $57-$ Lee (1981)

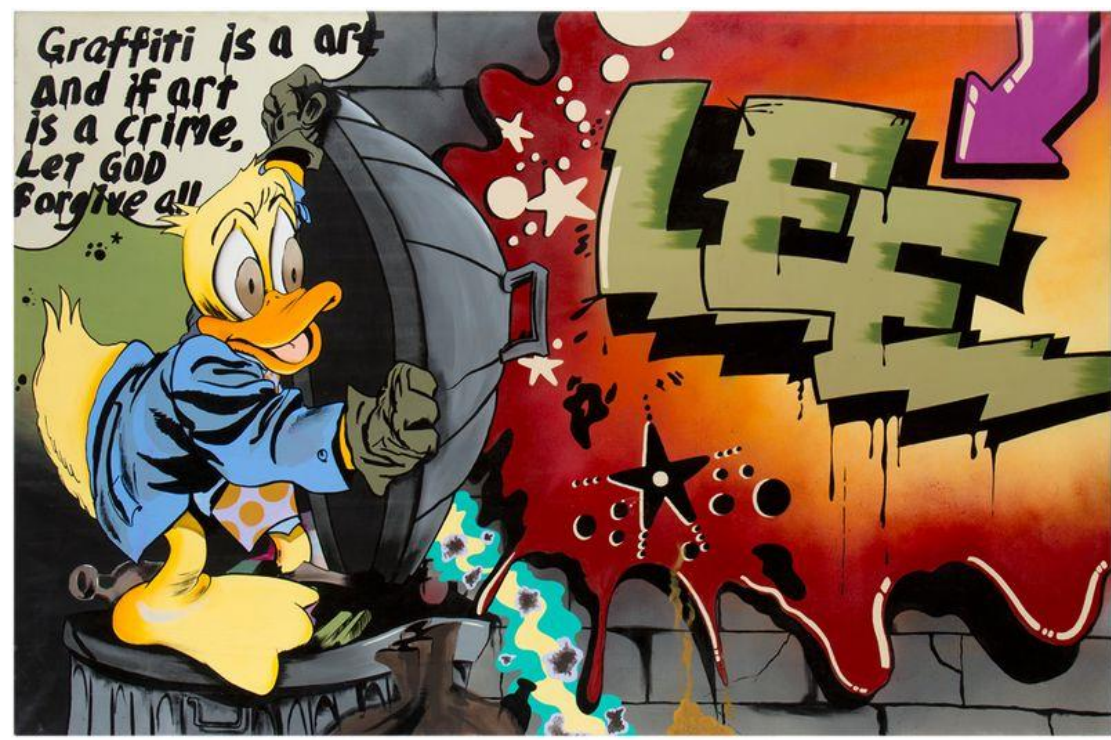

(CHALFANT; PRIGOFF, 2009, p. 14)

Para um grafiteiro de Nova Iorque, o metrô é o suporte mais cobiçado, pois devido às leis antigrafite o sujeito grafiteiro foi separado de seu objeto de desejo pelo antidestinador prefeitura de N.Y. Retornando a Lady Pink, o quadro trata, em termos narrativos, da conjunção do sujeito com seus valores de reconhecimento (fazer-se ver), figurativizados pela inscrição no vagão de metrô. Essa conjunção na narrativa é alcançada pelo auxílio positivo dos atores spray, que dá ao sujeito poder para fazer a inscrição, e o metrô, que é o suporte e divulgador dessa inscrição. Movida pelas determinações do grupo social grafiteiros, o ator "Lady Pink" realiza sua performance representada no quadro.

A tela somente mostra esse momento de conjunção, eufórico, não havendo espaço para nenhum movimento antitético. Esses elementos narrativos do plano do conteúdo estariam relacionados ao plano da expressão. O quadro pode ser dividido espacialmente em lado direito e lado esquerdo. Nessa divisão vertical, nota-se a figura da artista (sujeito) no lado esquerdo e o objeto-valor inscrição/grafite no lado direito, já os adjuvantes ocupam os dois lados, o spray acompanha o sujeito e o metrô, o 
objeto. Desse modo, os aspectos cromáticos são sobrepostos às categorias topológicas para a singularização desses três actantes no plano da expressão.

Verifica-se, então, o uso das cores em relação aos conteúdos narrativos. Os adjuvantes, vagão de metrô e spray, são monocromáticos com o uso predominante de cores frias (prata) e a figura do sujeito, em comparação com o restante do quadro, é policromática com uma preponderância para as cores frias, o azul esverdeado da pele do sujeito e seu colete roxo, ambos com tons metálicos, confirmariam essa perspectiva. Já a conjunção com o objeto é policromática, com a cor quente (laranja) para a inscrição e para a figura no canto inferior direito (azul, amarelo, vermelho e verde) com símbolos de corações, que reforçaria os valores positivos do objeto-valor. Portanto, a distribuição entre as categorias do plano da expressão e plano do conteúdo seriam:

Tabela 5 - Relações semissimbólicas em Lady Pink

\begin{tabular}{c|c|c|c} 
Plano do Conteúdo & \multicolumn{3}{|c}{ Plano da Expressão } \\
\hline Categoria & Topológica & \multicolumn{2}{|c}{ Cromática } \\
Sujeito & Esquerda & Policromático & Cor Fria \\
Adjuvantes & Esquerda e Direita & Monocromático & Cor Fria \\
Objeto & Direita & Policromático & Cor Quente
\end{tabular}

Pela estrutura do semissimbolismo, poderia ser dito que a conjunção entre sujeito e objeto traz consigo uma mistura no plano da expressão. O monocromatismo ligado ao objeto é encontrado na inscrição escrita e o policromatismo vinculado ao sujeito narrativo está identificado na figura com corações, então, a conjunção entre sujeito e objeto manifesta-se no plano da expressão pelo policromatismo, soma do mono ao policromático. O espaço ocupado pelo vagão de metrô, localizado ao fundo, e o primeiro plano da figura feminina com o spray intercalam o objeto-valor, intermediário, da inscrição escrita junto à figura arredondada com símbolos de coração. A seguir outra divisão esquemática sobre o quadro de Lady Pink: 


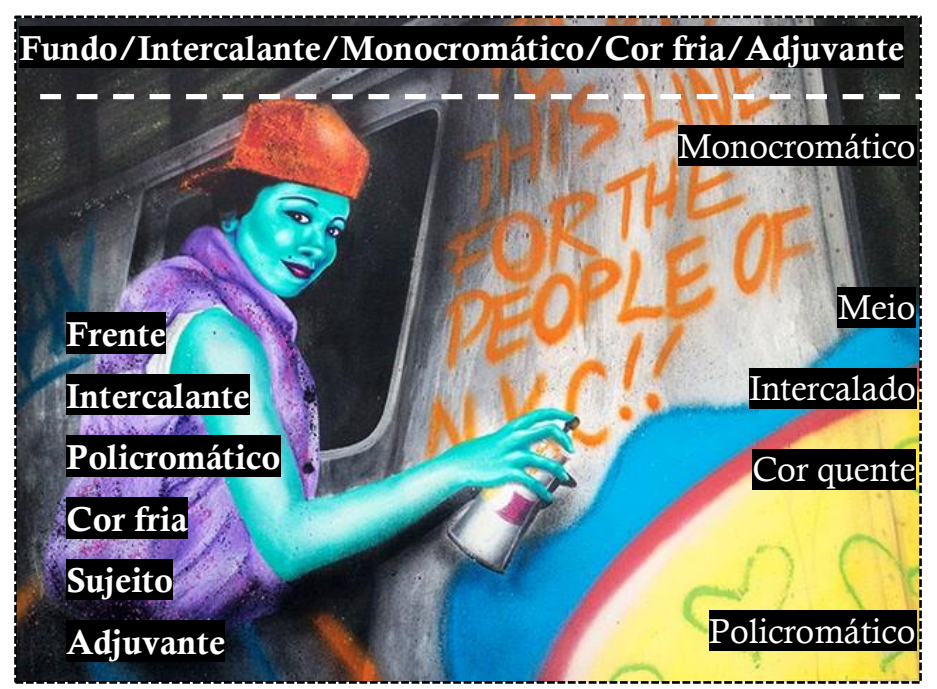

Não menos importante é o conteúdo verbal inscrito na superfície do vagão. Seu plano da expressão verbal não teria tanta intensidade se fossem considerados somente seus aspectos plásticos, mas o conteúdo da frase dá força à inscrição, cuja temática metalinguística é tão cara ao estilo grafite. Assim como o grafite de Lee, visto anteriormente, a inscrição de Lady Pink trata da condição do grafite na sociedade. Primeiramente, há uma fragmentação no início da frase que traria algumas variáveis, "to ko", "to ku", "to ro" e "to $r u$ ", mantendo a isotopia oferecida pelo restante da sentença e a coerência semântica da língua inglesa, o mais provável seria a variável "to ko", com dois significados em língua inglesa. Ko é uma abreviação de knockout, em português, nocaute, que expressa o fim de uma luta de boxe por meio de um golpe que deixa o oponente sem levantar por dez segundos. Em uma tradução livre, a frase poderia significar "para finalização" ou literalmente "para nocaute", em ambas as traduções o aspecto terminativo é mantido. Já por sua outra acepção, ko é uma abreviação de kick-off, em português, pontapé inicial, relativo a um aspecto incoativo (OXFORD, 2014).

Essa aspectualidade ambígua e oposta cria por sua vez uma leitura dual. Seguindo com o conteúdo da frase, "esta linha para o povo de NYC", identifica-se uma nova ambiguidade, porque line pode significar a linha de metrô ou a linha escrita. As possibilidades obtidas pela dualidade de $k o$ e line, sejam elas terminativas ou incoativas, sejam elas sobre o espaço ou sobre a própria frase, conduziriam a temática da liberdade de expressão, muito valorizada no decorrer da história das inscrições 
urbanas. As pessoas de Nova Iorque (people of NYC) são as detentoras do espaço metroviário, inclusive os grafiteiros, e os grafites que estão inscritos nos vagões são também para a cidade de Nova Iorque. É possível interpretar o conteúdo da frase, baseado no caso de Nova Iorque na história das inscrições urbanas, como uma reinvindicação de um espaço mais democrático (essa linha de metrô para o povo de NYC) ou uma intenção de produção (essa inscrição para o povo de NYC).

De toda forma, seria recuperado o discurso de liberdade dos grafiteiros contra a opressão do poder público, realizada pelas leis antigrafite, consolidando uma temática metalinguística tão cara às inscrições urbanas e à arte moderna. Todavia, afora o plano da expressão plástico da inscrição escrita, inserida no semissimbolismo do quadro, a mensagem "to ko this line for the people of NYC" tem sua força pautada no plano do conteúdo verbal, o "recado" dado aos cidadãos de Nova Iorque produziria uma carga estética pelo seu jogo de ambiguidades, pela temática metalinguística vinculada aos interdiscursos da história das inscrições urbanas em NYC.

Portanto, retoma-se uma problemática semelhante à mencionada na análise da função utilitária nas inscrições políticas do Maio de 1968. Essa mensagem na tela de Lady Pink pertenceria a uma função utilitária, ao enfocar a mensagem, porém, a função estética é identificada ao considerar o semissimbolismo da linguagem plástica. Como ambas encontram-se no mesmo texto, afirmaríamos que o quadro de Lady Pink empregaria as duas funções.

Entretanto percebe-se um campo difuso entre os extremos estético e utilitário, principalmente, quando o plano da expressão começa a ganhar intensidade. Além disso, seria possível considerar uma linguagem estética que só intensificasse o plano do conteúdo? Enfim, refletir sobre a direção de cada plano levaria talvez a uma maior produtividade descritiva, pois ao saber como essas forças relacionam-se, a análise torna-se mais exaustiva.

Para elaborar um mecanismo que analise os movimentos entre o plano da expressão e o plano do conteúdo nas inscrições urbanas, deve-se continuar a investigar essa relação no sistema de símbolo, recurso linguístico que ainda pode ser investigado mais profundamente. Após essa verificação, será possível compreender as tendências diretivas dos planos e poderia ser confirmada a proposta de divisão entre inscrições parisienses e nova-iorquinas que seriam caracterizadas pela maior valorização de um ou outro plano. 


\subsection{SISTEMA SIMBÓLICO E INSCRIÇÕES URBANAS.}

A abrangência no senso comum da palavra símbolo impede uma investigação exaustiva, porém, a definição hjelmsleviana de sistema simbólico (2006, p. 118) propõe uma restrição dessa multiplicidade. Essa variabilidade interpretativa na definição de símbolo pode ser observada no Dicionário Houaiss da língua portuguesa (INSTITUTO ANTÔNIO HOUAISS, 2012) e no Dicionário UNESP do português contemporâneo (BORBA, 2004), cuja heterogeneidade aparece em acepções imprecisas como "1. qualquer coisa usada para representar outra, especialmente objeto material que serve para representar qualquer coisa imaterial: o lírio é o símbolo da pureza" (BORBA, 2004, p. 1286) ou "1. aquilo que, por um princípio de analogia formal ou de outra natureza, substitui ou sugere algo; 2 . aquilo que, por pura convenção, representa ou substitui outra coisa" (INSTITUTO ANTÔNIO HOUAISS, 2012); chegando a definições mais próximas da linguística: "3. figura convencional elaborada expressamente para representar uma coisa; emblema, insígnia" (BORBA, 2004) e "1.4 sinal indicativo; signo" (INSTITUTO ANTÔNIO HOUAISS, 2012).

Essa disparidade já estava prevista no Dicionário de Semiótica (2008), que afirma o conceito de Hjelmslev (2006) sobre o sistema de símbolos, mas admite usos "nãolinguísticos e não-semióticos" do vocábulo. Como pode ser observado no verbete "símbolo":

[...] o termo símbolo admite definições múltiplas e variadas, tais como "aquilo que representa outra coisa em virtude de uma correspondência analógica" ou "ausência feita presença", etc. Em todos esses casos, não se questiona a natureza de signo, sendo que as determinações complementares que lhe são acrescentadas remetem ora ao caráter pluriisotópico do discurso, ora aos mecanismos ainda mal explorados de conotação, etc. O emprego desse termo sincrético e ambíguo deve, por enquanto, ser evitado em semiótica (GREIMAS e COURTÉS, 2008, p. 464).

O próprio Hjelmslev vai apontar as hesitações da Linguística de sua época para tratar do termo (2006, p. 118), contudo, a sua delimitação torna viável a abordagem semiótica. A isomorfia guia o conceito linguístico de símbolo, a conformidade entre os planos o define, mas basta criar essa correlação exclusiva para formar um símbolo? 
Melhor dizendo, a definição parte da análise do sistema simbólico, ou seja, todo símbolo possui essa estrutura, porém ela é suficiente para produzir um símbolo?

Sob o viés das inscrições urbanas, observam-se dois modos de lidar com o sistema simbólico, o que permitirá o aprofundamento da reflexão sobre o próprio sistema. O primeiro modo absorve o sistema de construção de símbolos em sua prática, cujos exemplos mais emblemáticos são a tag, o throw-up e a pichação. Entre essas três modalidades há uma mesma estrutura: a repetição simbólica para produção identitária. Suas diferenças ou variantes concernem, sobretudo, ao estilo tipográfico e à utilização do espaço. De acordo com a história das inscrições urbanas, sabe-se que a produção dessas variantes se deu pela tentativa de individualização de cada estilo. Devido ao excesso de repetição, a tag levou ao throw-up, que levou ao grafite e assim sucessivamente. Já a pichação é uma versão dessa mesma prática, adaptada à cultura urbana brasileira.

Em uma abordagem do sistema simbólico, os elementos que singularizam cada modalidade não são pertinentes, mas suas recorrências estruturais que perpassam as três modalidades o são, colocando-as sob uma mesma classe. Então, toma-se a pichação como exemplo-tipo, pois ela mantém a invariância das outras modalidades, com a vantagem de ser uma prática contemporânea brasileira, possibilitando sua verificação in situ.

A assinatura estilizada tipograficamente pela pichação é singular, porque após sua composição, o pichador deve espalhá-la exaustivamente pela cidade para a afirmação de sua identidade. Mesmo para os enunciatários que não possuem a competência necessária para ler o picho e relacioná-lo a valores de identidade do enunciador, por exemplo, o significado do nome correspondente à assinatura; permanece uma associação da expressão ininteligível a um programa narrativo, no qual um sujeito, anônimo, busca valores de identidade ou reconhecimento (ibope) pela produção do objeto-valor inscrição urbana. Esse reconhecimento de alguém que foi a determinado lugar para fazer sua assinatura ganha cada vez mais força identitária conforme a quantidade de repetição de sua marca aumenta, ou seja, é possível vincular diretamente ao picho uma identidade.

As diferenças de recepção estariam vinculadas à capacidade do enunciatário de apreender a sintaxe discursiva do enunciado. Um enunciatário competente lê as marcas enunciativas deixadas no enunciado, nome, data e região, já um enunciatário 
não-competente não perceberia essas marcas e consideraria o picho um enunciado enuncivo. Essas aproximações e afastamentos passam também por embreagens, pois a identificação da projeção espacial e temporal no texto é mais acessível ao leitor desapercebido que a projeção do enunciador na assinatura. Vale destacar que o enunciado "picho" pode ser entendido como enuncivo ou enunciativo em função da competência do enunciatário e não somente pelos traços deixados pelo enunciador no enunciado.

Afora as distinções sintáxicas produzidas na recepção do picho, a conformidade de um conteúdo identitário à sua expressão seria reconhecida, ou seja, em termos hjelmslevianos, o picho seria um símbolo. Prontamente, surgiria uma contra-argumentação afirmando o caráter simbólico da assinatura de pessoas físicas ou até mesmo do nome de batismo, pois haveria conformidade entre o plano da expressão e o conteúdo, alargando o conceito de símbolo. A resposta seria sim, se fosse considerada a definição de símbolo somente como uma semiótica monoplana. Contudo retoma-se a pergunta, a estrutura do sistema simbólico é suficiente para a identificação do símbolo?

Pela investigação do sistema simbólico nas inscrições urbanas, dir-se-ia não, porque dois fatores não teriam sido considerados, a repetição e o tempo. Observa-se que não se discorda da definição de Hjelmslev (2006) sobre o sistema simbólico, em que todo símbolo é uma semiótica monoplana, mas nem toda isomorfia entre os planos produziria um símbolo. Consequentemente, nem a assinatura de pessoa física, nem o nome de batismo e talvez nem a pichação sejam símbolos, pois sua repetição no tempo seria insuficiente.

Propõe-se, então, que além da isomorfia entre os planos, o símbolo deva ser compreendido por meio de sua repetição no tempo, aliás, acredita-se que pela repetição do símbolo no tempo seja alcançada a isomorfia entre os planos. Embora a tese não busque fazer um tratado geral dos símbolos e tampouco seja uma investigação sobre os discursos religiosos e políticos dos símbolos abordados. Pensa-se sobre eles em termos gerais, excluindo qualquer aprofundamento nas ciências que os envolvem.

Assim, os exemplos clássicos sobre os símbolos, a suástica relacionada ao nazismo ou a foice e o martelo para o comunismo, não se tornaram símbolos automaticamente após sua criação. Quando o Partido Comunista adotou em 1918 o 
emblema criado por Evgueni Kamzolkin, o comunismo possuía outros símbolos concorrentes, como martelo e arado, martelo e forquilha etc. (KHUTAREV, 2014), mas foi pela bandeira da União Soviética e pela reprodução massiva de seu símbolo ao longo do século XX que a foice e o martelo tornaram-se símbolos do comunismo, mesmo depois do fim da União Soviética.

O mesmo vale para a suástica, que foi um emblema bastante empregado em diversas culturas desde o período Neolítico. Porém, a partir de 1920, com a criação do partido Nationalsozialistische Deutsche Arbeiterparteit, Partido Nacional Socialista dos Trabalhadores Alemães, a Hakenkreuz (cruz gamada ou cruz com ganchos), destacada de um fundo vermelho e de um disco branco, foi gradativamente associada ao discurso de Hitler e ao Nazismo, afastando-se do termo socialista que o partido carregava, até ser considerada em 1935 como bandeira nacional da Alemanha. Atualmente, o símbolo está inteiramente ligado ao nazismo, mesmo depois do fim desse período histórico, e perdeu completamente, no Ocidente, sua relação com as culturas do passado ${ }^{40}$.

Nos dois exemplos citados, os emblemas tinham inicialmente diversos conteúdos relacionados a eles, movimento trabalhador, revolução russa, socialismo, no caso da foice e do martelo, e no caso da suástica do Partido Nacional-Socialista, movimento dos trabalhadores, força política alemã e Hitler. Conforme os discursos foram se concentrando concomitantemente à reprodução do emblema, a marca ganhava em força e unidade até chegar a uma relação unívoca entre conteúdo e expressão.

Não se busca uma resposta para os motivos históricos que levaram à concentração de conteúdos para a formação do símbolo, especula-se: talvez houvesse uma convergência de narrativas próximas (no exemplo da foice e martelo, da revolução russa, do movimento trabalhista e do socialismo) com sujeitos diferentes buscando os mesmos valores, delegados pelo mesmo destinador. Essa convergência poderia ter sido alcançada pela conjunção de um desses sujeitos narrativos (Partido Comunista) com o objeto-valor por meio de uma disputa ou pela união desses sujeitos, que partilham os mesmos valores, para realizar um único programa narrativo.

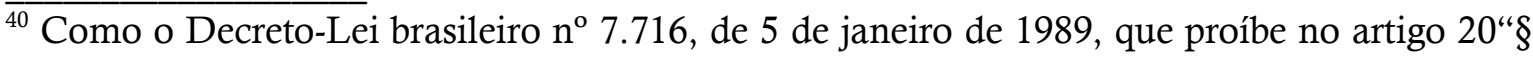
$1^{\circ}$ fabricar, comercializar, distribuir ou veicular símbolos, emblemas, ornamentos, distintivos ou propaganda que utilizem a cruz suástica ou gamada, para fins de divulgação do nazismo" (BRASIL, 1989).
} 
Entretanto, para o estudo do sistema simbólico na diacronia, a relevância está na concentração desses conteúdos, pois sua alta extensidade produziria, em uma relação inversa, baixo impacto, quer dizer, cada repetição do símbolo, um acento, poderia ser vinculada difusamente a diversos conteúdos (FONTANILLE e ZILBERBERG, 2001). A exaustiva seleção de conteúdos levaria a um estado-limite, ao único. Por consequência, o acento de cada repetição conduziria a uma maior tonicidade, porque não haveria mais a dispersão de conteúdos.

Voltando ao exemplo da foice e do martelo, quando o símbolo foi criado em 1918, vários discursos eram atrelados não somente à foice e ao martelo, mas também a outros emblemas concorrentes (enxada e martelo, forquilha e martelo etc.), assim como discursos diferentes. A convenção na escolha da foice e martelo eliminaria suas variantes, do mesmo modo que o estabelecimento do Partido Comunista concentraria a anterior difusão de conteúdos. Esse processo de triagem (FONTANILLE e ZILBERBERG, 2001) chega ao seu ápice pela extinção da forma do conteúdo, que a certo momento passa a considerar um sentido geral de comunismo ao invés de Partido Comunista. Nesse momento, chega-se ao mínimo, o signo torna-se símbolo e a correlação entre os planos é unívoca, pois:

\footnotetext{
Hjelmslev vai chamar sistemas de símbolos essas estruturas que são interpretáveis, porque se pode atribuir a elas um sentido, uma substância de conteúdo, mas são monoplanares, dado que não é possível atribuir a elas uma forma de conteúdo, já que expressão e conteúdo são reduzidos a uma só classe (FIORIN, 2003, p. 44).
}

No caso do comunismo, acredita-se que a dependência entre a expressão e o conteúdo é causada pela repetição (HJELMSLEV, 2006, p. 42-43), pois a condensação dos conteúdos seria determinada pela repetição da expressão, levando à formação do símbolo. Em termos históricos, a fixação do emblema (anterior à condensação de conteúdos) conduziria por sua repetição à conformidade entre os planos.

Nesse tipo de dependência, em que um termo pressupõe o outro, mas não o contrário, encontra-se uma relação unilateral. A determinação é designada como seleção, quando se trata de um processo, e como especificação, quando se trata do sistema (HJELMSLEV, 2006). Seguindo com o exemplo, a repetição ocorrida no plano da expressão selecionaria conteúdos. 
Em termos tensivos, não se trata de subvalências que formarão valores, mas de valores que se comportam como subvalências para criação de valores de valores. Os conteúdos e expressões considerados já possuem seus respectivos valores, então, busca-se encontrar um sistema para descrição desse processo supravalorativo. Em razão desse ponto de vista, ambos os planos, formados por extensidade e intensidade, entrariam em um processo de minimização.

O plano da expressão em seu regime exclusivo atingiria uma extenuação da extensidade, devido à proposta da convenção em estabelecer um único emblema, cujo acento seguiria o caminho inverso, rumo à tonicidade. Essa triagem levada a cabo chegaria ao único, causando uma parada processual, uma retenção, pois sua continuação resultaria em um processo inverso ou a uma extinção. No plano do conteúdo, a difusão de significados traria a atonia, pois, caracterizada pelo regime exclusivo, a repetição do emblema perderia em impacto, porque a cada vez repetido, seu significado poderia ser interpretado de maneiras diversas, mas limitadas. Como se a repetição do significante, foice e martelo, girasse no vazio, criando uma continuação da parada.

Essa inadequação retensiva dos planos exigiria uma resolução em um dos planos, por isso um processo de concentração dos conteúdos seria iniciado para ajustar-se ao plano da expressão. Essa seleção, em um regime inverso, reverteria gradativamente a atonia rumo à alta tonicidade. A repetição agenciaria a adequação entre os planos justamente por expor seu descompasso.

\begin{abstract}
Ainda que se possa dizer que essa tensão está ligada às flutuações presentes no imaginário humano e que tais flutuações se manifestam nas oposições do sistema linguístico, uma vez fundado o sistema, gera-se uma necessidade interna de mudança. Um texto que se mantém sempre numa mesma fase produz um estranhamento, um mal-estar. Assim, a repetição será administrada de forma a preparar a mudança e criará uma tensão expectante de mudança (LEMOS, 2015, p. 132) $)^{41}$.
\end{abstract}

A distensão promoveria a retomada do processo de ajuste rumo ao relaxamento entre os planos. Essas transições tensivas, de paradas e continuações, podem ser observadas no esquema a baixo:

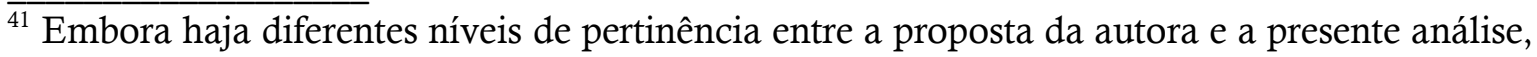
julgam-se pertinentes suas considerações, devido ao seu ponto de vista sistêmico.
} 
Esquema 8 - Quadrado semiótico de paradas e continuações

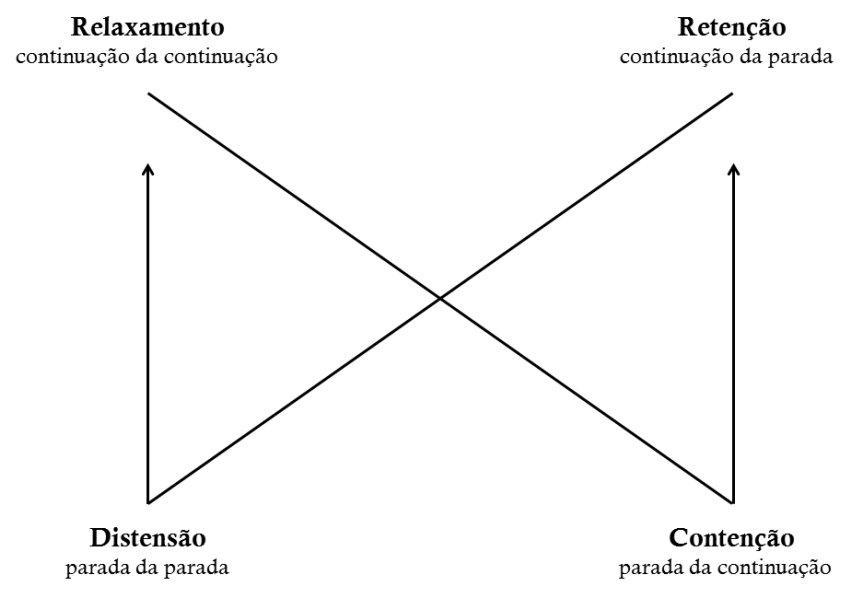

A sequência processual de paradas em direção às continuações teria a seguinte configuração nos esquemas tensivos, nos quais a extensidade está relacionada no plano da expressão ao número de variantes plásticas do(s) emblema(s) e no plano do conteúdo, à difusão dos significados, e a intensidade está ligada ao impacto produzido por suas respectivas repetições.

Esquema 9 - Relação tensiva entre os planos

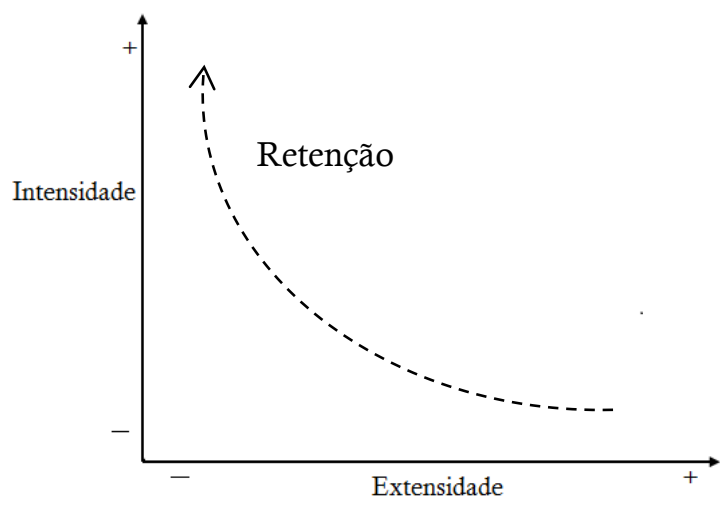

Plano da Expressão

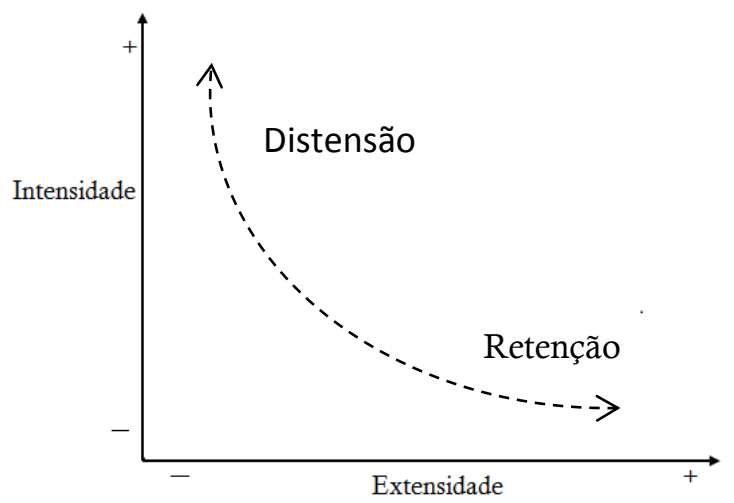

Plano do Conteúdo

Porém o que ocasiona essa triagem? Como um conteúdo torna-se mais concentrado em relação a outros? Para isso, deve haver um fator selecionador nessa difusão de significado.

Ora, dentro desse universo de potencialidades, haveria a eleição de determinados usos em detrimento de outros. Por meio de sua repetição efetuada pelo grupo social, um conteúdo teria maior saliência que outro. Eis o conceito de norma 
linguística, já que algumas formas são mais empregadas, então, o uso vai determinar essa seleção e isso pode ser atribuído a diversos fatores, como a eficiência na comunicação. Logo, movidos pelos valores de concentração, que vão regular a tensividade dos conteúdos, a norma endógena (daquele grupo russo) passa a ser a regra geral (KLINKENBERG, 2010).

No caso do comunismo, em um exemplo de estabelecimento do símbolo como norma, quando o emblema tornou-se símbolo, houve uma necessidade de colocá-lo nas bandeiras de todo país seguidor daquela ideologia (norma exógena). Entretanto, como a norma exógena prevê, em um sistema de oposições, uma norma endógena, o Partido dos trabalhadores da Coréia do Norte não segue as normas do símbolo, produzindo uma norma endógena: sua bandeira constitui-se da sobreposição das figuras do martelo, enxada e pincel, representando respectivamente os operários, os trabalhadores rurais e os intelectuais. A constituição do símbolo como norma dá-se, então, por sua repetição em uma práxis enunciativa e o enunciador seria conduzido a realizar a forma mais recorrente. O próprio sistema linguístico regularia a determinação dos valores. No entanto, como foi mencionado anteriormente, o percurso tensivo do sistema simbólico leva à extinção do plano do conteúdo e o que era signo passa a ser símbolo, porque a repetição normativa deixa de ser local para ser global.

Segundo Lemos (2015), a repetição poderia ser percebida em termos globais e locais na linearidade textual.

O componente global é estabelecido pelo recorte de extremidades e cria uma totalidade. O componente local cria intervalos e segmenta o texto em partes. Ao integrar o ritmo, a repetição requer uma noção global e outra local, de todo e de parte, para se fazer sentir. Precisamos tanto da identificação, quanto da linearidade e da saliência [...].

Em outra escala, a repetição também age de forma intensa e/ou extensa no texto. Entendemos extenso como uma força centrífuga que espraia o sentido e é, portanto, coextensivo ao texto. Intenso, inversamente, é a força centrípeta e concentradora do partitivo, de valores expressos por uma ou mais partes (LEMOS, 2015, p. 137).

Transposto esse excerto para o sistema simbólico, a repetição local dispersa o acento do plano da expressão por causa de seus conteúdos diversos, mas quando o estabelecimento normativo nesse regime de minimização promove um único 
significado, a repetição local torna-se global. Seria possível afirmar que nesse caso de produção simbólica por determinação, a repetição local, retensiva, teria como resolução outra repetição, distensiva.

Além disso, há uma linearidade temporal no caso do símbolo, pois as repetições ocorrem sucessivamente em um determinado período de tempo na história, mas a espacialidade é planar, pois não há linearidade no espaço da repetição simbólica, ele ocorre em diversos lugares separadamente. Somente o percurso linear temporal estabelecido pelo enunciatário em sua leitura reúne essa exposição simbólica espalhada espacialmente. Essa intermitência da repetição cria um acúmulo, gerador de uma intensificação de conteúdo.

É preciso ressaltar que a norma não é a responsável integral pela produção do sistema simbólico, senão a maioria do sistema linguístico seria monoplanar, anulando sua própria condição semiótica, mas sua progressividade excessiva geraria o símbolo. O sistema simbólico seria resultado de um sistema de excesso tensivo. A determinação da repetição (HJELMSLEV, 2006), conduzida pela norma (COSERIU, 1979), sobre os planos de expressão e de conteúdo somada a um processo de minimização extremo (ZILBERBERG, 2011b) gerariam o símbolo.

Como foi visto no caso do comunismo e do nazismo, a definição do emblema, expressão concentrada átona, estava ligada inicialmente a certos conteúdos, cuja repetição local criava total atonia do signo. Porém a seleção dos conteúdos pelo uso de um emblema, levada à extenuação, resultou em um único conteúdo, o Partido Comunista e o Partido Nazista, que atingiria a extinção do plano do conteúdo resultando em um sentido abstrato (substância): o Comunismo, o Nazismo. Nesse momento, a repetição do símbolo distende-se globalmente.

Esse excesso que rompe limites é o produtor da extinção e essa mudança é compreendida pela dimensão concessiva. Embora a relação inversa entre as valências dos planos seja notadamente marcada, cada eixo é direcionado implicativamente. No caso dos exemplos acima, enquanto a extensidade seguia para o cada vez menos, a intensidade ia para o cada vez mais, ou seja, a relação inversa (ou ...ou) internamente a cada eixo seria constituída de uma relação conversa (e ...e). Consequentemente, o ápice da dimensão implicativa dentro de cada eixo seria a extenuação na extensidade e a saturação na intensidade, isso quer dizer, um "signo mínimo". A partir dessa configuração, a lógica concessiva sobreviria a essa relação, pois seguindo o regime 
implicativo das categorias minimização e recrudescimento, o "próximo passo" seria na direção inversa:

Diante de uma ascendência realizada, ou seja, de um paradoxismo absoluto de plenitude comportando unicamente mais, o desencadeamento da descendência consiste necessariamente na subtração de, pelo menos, um mais. À continuação desse processo, damos o nome de atenuação, definindo-a em termos de degressividade como projeção no campo de presença, de cada vez menos mais (ZILBERBERG, 2011b, p. 56).

Contraditoriamente, o limite do regime implicativo é uma concessão, pois embora haja somente mais, seu bloqueio é inevitável rumo ao somente menos. Seguindo esse raciocínio, a concessão que sobrevém a essa implicação nada mais é que a continuação do processo implicativo inicial, esse somente mais é dirigido concessivamente para o acréscimo de mais de um mais, já que seu percurso "natural" seria descendente. Portanto, a extinção seria a decorrência concessiva da extenuação, que instalaria uma extensão do limite tensivo para em seguida voltar à lógica implicativa, cuja consequência é a dimensão descendente (ZILBERBERG, 2012, p. 28). Essa flutuação dos limites traz maior dinâmica às relações entre os termos:

$\mathrm{Na}$ perspectiva contínua dos modelos extensivos [...]. O intervalo é sempre variável entre dois extremos, conforme as possibilidades do sistema considerado. Sua alteração traz consequências importantes ao modelo descritivo. Um aumento no número de termos da estrutura faz aumentar o intervalo entre os extremos e torna mais fina a determinação da intenção [...] (LOPES, 2004, p. 46).

Os limitadores situados no extremo do eixo tensivo tornam-se intermediários por conta da mudança concessiva, porém, vale ressaltar, isso é um acontecimento no sistema e como tal, não pertence à regra geral, ou seja, a formação do sistema simbólico é uma exceção prevista no sistema. 


\section{Esquema 10 - Extenuação do conteúdo}

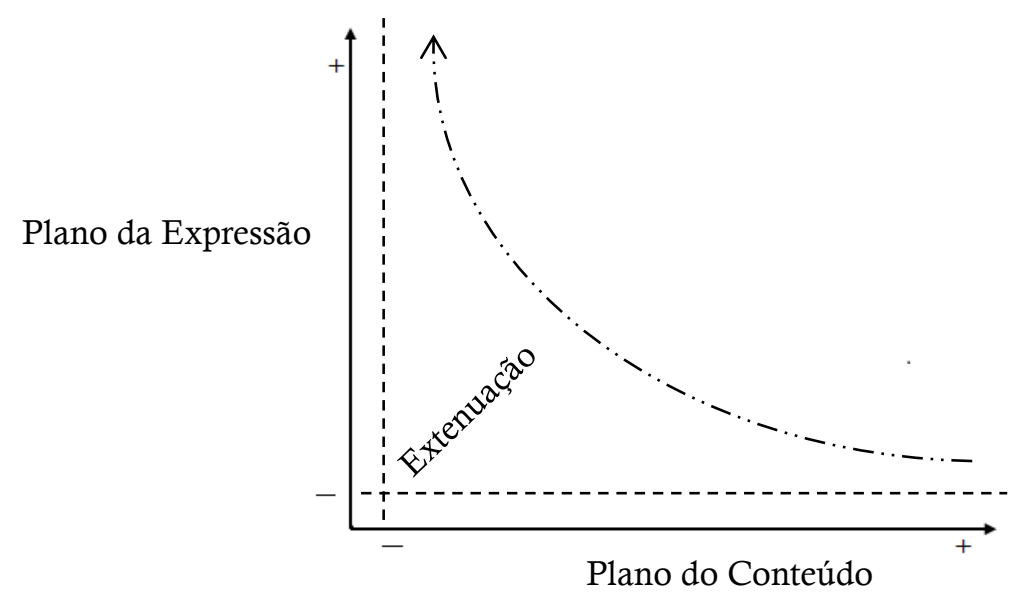

A repetição global do único gera um aumento no impacto, a expressão do símbolo em conformidade com um conteúdo exclusivo não possui mais potenciais concorrentes na distribuição do sentido, não há mais distribuição, o símbolo deixa seu único significado ao ser manifestado. A norma local é alçada ao estatuto de regra geral e toda variante estará em oposição ao símbolo estabelecido no sistema, caracterizando um desvio. A anterior concessão atribuída aos aumentos e diminuições da repetição retorna à lógica implicativa. O conteúdo e a expressão do símbolo, em relaxamento, não se expandem e nem se concentram, sua pertinência estará na quantidade da repetição relacionada ao impacto. Contudo, segundo a lógica da própria repetição, "a ausência total de mudança leva a uma estagnação: o texto volta sempre ao seu início e não há evolução" (LEMOS, 2015, p. 130). Porém um acontecimento (ZILBERBERG, 2011b) pode rearranjar a monotonia repetitiva do símbolo, levando-o talvez a um processo inverso de expansão dos conteúdos ou quiçá a uma maior concentração.

Tal processo não integra o escopo da tese e aparentemente ele só poderia ser previsto nas virtualizações do sistema, sem haver ainda uma realização semiótica. Como esse tema ultrapassa os limites da presente investigação, mais uma vez tratamse de especulações.

Seguindo com a proposta inicial, a formação do símbolo é entendida como determinada. Nos casos apresentados, a concentração do plano do conteúdo regida pela repetição da expressão constituiria o símbolo. Desse modo, é importante verificar a relação inversa, a repetição que expande o conteúdo. 


\subsubsection{PICHAÇ̃̃O}

A pichação seria um caso desse tipo de relação determinada pela repetição do plano da expressão que expandiria o conteúdo, assim como suas formas antecessoras, o throw-up e a tag. Do mesmo modo que o símbolo comunista aparece iterativamente, seja em bandeiras, na televisão, em cartazes etc., a pichação também está disseminada, na cidade, descaracterizando uma estrutura dependente da linearidade espacial. Será por meio do percurso cronológico linear das repetições que o enunciatário vai juntá-las e dar-lhes sentido.

$\mathrm{Na}$ dependência anteriormente analisada, foi considerado que a extensão do plano do conteúdo impediria uma formação unívoca, mas a repetição local e a seleção normativa produziriam a concentração dos conteúdos até atingir concessivamente sua extinção. Em um movimento oposto, a repetição da expressão única daria sentido ao conteúdo.

As primeiras pichações lidas pelo enunciatário estariam esvaziadas de sentido, já que seria uma inscrição ininteligível, uma marca qualquer na cidade. Mesmo para os enunciatários competentes, aquelas poucas inscrições não atestariam um valor identitário. Conforme esse mesmo enunciatário, competente ou não, é atingido por uma repetição numerosa da pichação, expandida no espaço urbano, iniciar-se-ia um processo de associação daquelas primeiras marcas sem conteúdo a uma série feita pelo mesmo enunciador. Um conteúdo identitário emergiria dessa expressão sem sentido, cuja repetição seria a responsável pela expansão do conteúdo.

Em termos tensivos, essas primeiras repetições sem sentido conduziriam a um movimento retensivo, uma continuação da parada, que a certo ponto deixa de ser uma repetição local para integrar um todo de sentido, uma série. Essa passagem da retenção para o relaxamento, acompanhada da mudança da percepção local para global dá-se em um processo de acumulação que seria difícil distinguir a etapa intermediária da distensão. A ascendência valencial do plano do conteúdo só seria percebida no acréscimo de pelo menos um mais, pois na categoria do restabelecimento, a redução de menos não criaria conteúdos (do zero), somente pelo acréscimo, a distensão entraria no processo rumo ao relaxamento. 
De acordo com as propostas da semiótica tensiva nos dois casos do sistema de símbolo, a intensidade regeria a extensidade. A repetição daria consistência para que a concentração ou expansão do conteúdo do enunciado se tornasse inteligível e assim se fixasse no campo de presença enunciativo. Dessa forma, a repetição direcionaria a extensidade que por sua vez produziria um aumento intensivo ${ }^{42}$.

\section{Esquema 11 - Lógica implicativa na pichação}

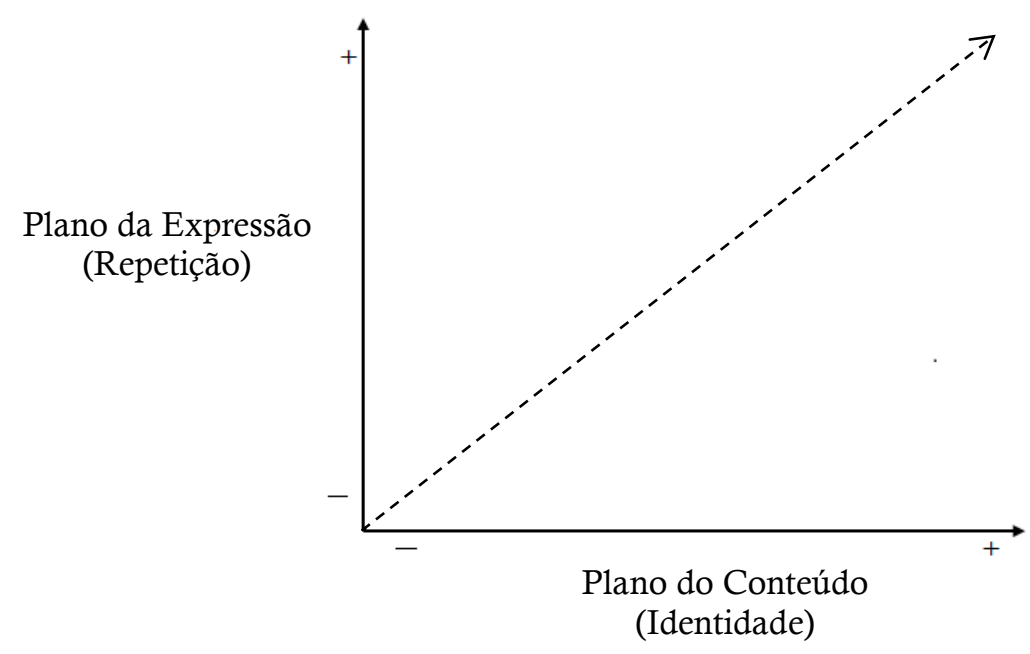

Nota-se que a repetição conduziria a uma lógica implicativa e a dimensão ascendente no plano do conteúdo e no plano da expressão não exigiria sua saturação para a formação simbólica. A relação entre a extensidade e a intensidade seria conversa, a quantidade de pichos, sua extensão, seria proporcional à sua tonicidade.

Enquanto no caso anterior do sistema de símbolo, a norma propiciava a concentração de conteúdos; na pichação, ela os expande. A prática da pichação estabelece suas próprias regras internas de repetição e ao segui-las, a inscrição sai do limbo sem sentido para a afirmação de identidade. As normas endógenas da prática já preveem o uso adequado da repetição para a formação do símbolo, pois a manutenção exaustiva da unidade ampliação possibilitaria a constituição do símbolo (ZILBERBERG, 2011b). No entanto a repetição não é o único fator a ser considerado na estrutura do símbolo, o tempo também é um definidor desse processo.

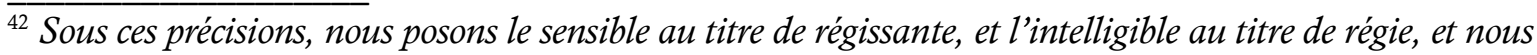
recevons le déficit modal de celui-ci à l'égard de celui-là comme l'un des secrets de l'affect: "Le propre du monde intellectuel est d'être toujours bousculé par le monde sensible [...]" (ZILBERBERG, 2007b, p. $3)$.
} 
Símbolos produzidos pela concentração de conteúdos tardaram décadas para constituírem-se, além de sua repetição ser massiva, a foice e o martelo eram divulgados em vários países por meio de vários meios de comunicação, a fama nazista de sua comunicação de massa baseava-se fortemente na repetição; o que acelerava a extenuação de conteúdos concorrentes à unicidade dos planos.

De outro modo, a pichação não tem consistência temporal para estabelecer-se enquanto símbolo, nem dispõe de recursos massivos de repetição para acelerar esse processo. Devido à prática ser considerada crime, as pichações geralmente param de ser produzidas ou reduzem sua repetição quando o pichador faz dezoito anos (idade penal). Mesmo com as estratégias de "herança", segundo as quais um pichador mais velho autoriza um pichador mais novo a utilizar sua marca, ou de "família", em que vários pichadores escrevem o mesmo picho, produzindo um mesmo enunciador; o impacto ainda é diminuto, já que a prática ainda é recente.

Essa falta de consistência de repetição no tempo impossibilitaria um total reconhecimento do picho com o de um conteúdo identitário. Embora a estratégia seja válida, ampliar o conteúdo por meio de uma repetição da expressão, esse sem sentido que ganha sentido não é suficiente para cristalizar-se na linguagem como símbolo. A inscrição baseada em normas endógenas não alcança o patamar de um conteúdo geral, porque em alguns anos a repetição cessa e a marca dá lugar a outras marcas concorrentes.

Ainda assim a pichação seguiria um processo de construção simbólica, que se constitui dentro do sistema pela expansão. Portanto, o primeiro modo de relacionamento das inscrições urbanas com o símbolo seria por via do seu sistema, em que as normas da pichação seriam formadas pelos mesmos processos de construção do símbolo e ela seria um símbolo em potencial. No entanto o que se vê nessa sua repetição, é a falta de consistência temporal. Seu conteúdo identitário estabelecido por conta da repetição em série poderia fixar-se em uma relação unívoca entre os planos, se fosse mantida a continuação da continuação. Todavia a parada da continuação atinge o processo e a presença da repetição esvai-se na competição com outros símbolos em potencial.

Retornando às funções da linguagem, como poderia ser caracterizado o recurso do sistema de símbolos na pichação? Uma função estética ou utilitária? Posto que esse procedimento integre a própria estrutura da prática, cujo plano da expressão não 
preenche funções utilitárias e a força de seu conteúdo identitário afirma uma estética da repetição, a pichação seria estética. Entretanto, se ela fosse vista somente por sua repetição local e pela veiculação de um conteúdo identitário ou de um momento "eu estive aqui" - uma assinatura no espaço urbano, como iniciais dentro de corações talhados em árvores - sua carga estética seria perdida. Mais uma problematização emerge do aprofundamento das relações entre os planos nas inscrições urbanas.

\subsection{SÍMBOLO DENTRO DAS INSCRIÇÕES}

O segundo modo de utilização do sistema simbólico nas inscrições urbanas é por meio da intertextualidade, que "é o processo de incorporação de um texto em outro, seja para reproduzir o sentido incorporado, seja para transformá-lo" (FIORIN, 2011, p. 30). Dividida em três tipos, citação, alusão e estilização, a intertextualidade parte da presença de um texto em outro até a incorporação estilística. A citação é definida pela manifestação de um texto em outro, assim, a palavra do outro é "recortada" e "colada" no texto citante. Na alusão:

[...] não citam as palavras (todas ou quase todas), mas reproduzem-se construções sintáticas em que certas figuras são substituídas por outras, sendo que todas mantêm relações hiperonímicas com o texto hiperônimo ou são figurativizações do mesmo tema. [...] (FIORIN, 2011, p. 31)

E a estilização:

[...] é a reprodução do conjunto dos procedimentos do "discurso de outrem", isto é, do estilo de outrem. Estilos devem ser entendidos aqui como o conjunto das recorrências formais tanto no plano da expressão quanto no plano do conteúdo (manifestado, é claro) que reproduzem um efeito de individualização (FIORIN, 2011, p. 31). 
Fiorin (2011) trata dessas relações intertextuais principalmente na semiótica verbal, entretanto, ele mesmo afirma que esse é um recurso estrutural e, como tal, pode ser encontrado em outras semióticas ${ }^{43}$.

No caso das inscrições urbanas, verifica-se que os símbolos são geralmente citados ou aludidos, pois uma estilização simbólica não seria viável devido à ausência de forma de conteúdo do símbolo. Esses mesmos recursos encontram-se amplamente nas inscrições urbanas sem o emprego do símbolo. Banksy é um artista emblemático no uso desses três tipos de intertextualidade, porém, o interesse da tese fixa-se nas relações entre os planos para a compreensão das funções estética e utilitária dos textos. Segue-se, então, a análise da utilização simbólica nas inscrições urbanas de maneira intertextual.

Na citação, o símbolo aparece em sua manifestação textual, ou seja, realizado no texto citante. Por exemplo, a inscrição Peaceful Hearts Doctor de Banksy cita o símbolo da paz, "criado pelo artista britânico Gerald Herbert Holtom (1914-1985) para a 'Campanha do Desarmamento' (Campaign for Nuclear Disarmament-CND) pertencente ao 'Movimento da Paz' em 1958" (7 GRAUS, 2008), que posteriormente foi associado ao movimento hippie nos anos de 1960 sob o mote peace and love (paz e amor); para satirizar sua relevância nos dias atuais.

Figura 58 - Peaceful Hearts Doctor (São Francisco, EUA)

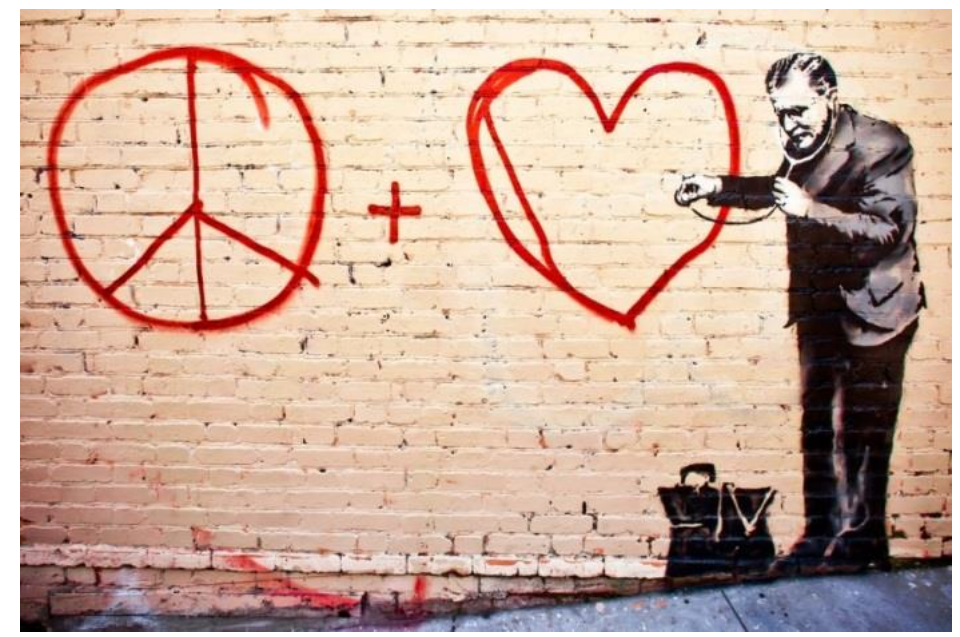

(BANKSY, 2014)

\footnotetext{
${ }^{43}$ Os trabalhos sobre intertextualidade e interdiscursividade em Oliveira (2016) e em Dondero (2006) discutem o conceito sob o viés de seus objetos de estudo, respectivamente, o cinema e a fotografia. No entanto não se encontra uma mudança nas propostas de Fiorin (2011), que continuam válidas na análise de outras semióticas.
} 
Já na alusão, traços do texto-fonte são recuperados no texto citante, como a sintaxe ou suas figuras. No caso das inscrições urbanas, categorias cromáticas, eidéticas e topológicas são mantidas para remetê-las ao texto original, mas com desvios consideráveis deixando potencializada a presença da citação. Como na inscrição anônima (THE CRYPT, 2002) composta pela citação de símbolos comerciais, como Coca-cola, Nike e Visa; do símbolo dos Jogos olímpicos e da alusão feita à figura simbólica de Ronald McDonald, símbolo comercial do McDonald's ${ }^{44}$.

Figura 59 - Inscrição anônima feita no período dos jogos olímpicos de Londres

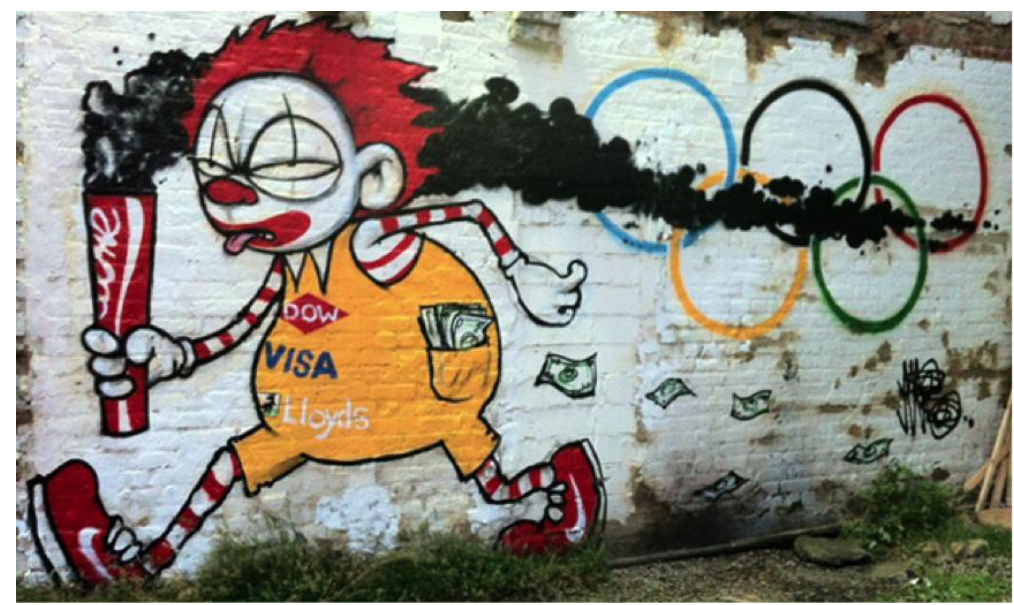

(THE CRYPT, 2002)

Nessa inscrição satírica, símbolos relacionados aos patrocinadores dos Jogos Olímpicos de Londres estão ligados a uma alusão da figura de Ronald McDonald, símbolo da empresa McDonald's. Por meio da recuperação das cores e pelo desvio de formas, as linhas do desenho compõem uma figura bem diferente da original, o tema esportivo relacionado ao patrocínio dessas marcas de forma eufórica, recorrente no discurso dos Jogos, é expandido para uma tematização política disfórica vinculada à sustentabilidade e ao neoliberalismo.

Geralmente, o emprego do símbolo nas inscrições urbanas possui uma função estética. As modalidades que se aproveitam dos símbolos para desviá-los ou estender

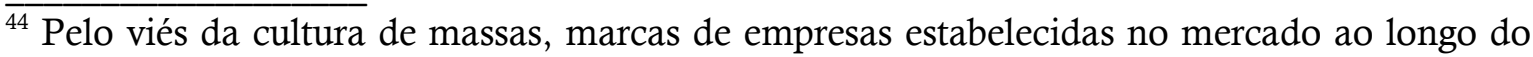
século XX alcançaram com seus logos e personagens a condição de símbolo nesse tipo de cultura por meio da repetição exaustiva de propagandas e distribuição de seus produtos. Um conteúdo de identidade, a empresa, estaria associado univocamente a uma expressão, seu logo.
} 
seus significados já o fazem para criar um impacto estético no enunciatário. A transmissão de conteúdos deixa de ser o único destaque nessa produção.

Assim, o emprego dos símbolos nas inscrições urbanas ocorre pela intertextualidade, via citação ou alusão, ou pela absorção da estrutura simbólica, como é o caso da pichação. Retoma-se a discussão sobre a relação entre os planos para compreender os conceitos de função utilitária e estética da linguagem, que poderiam ser ligadas às modalidades de inscrições urbanas de Paris e Nova Iorque. Porém, segundo a análise de alguns exemplos, verificou-se que essa possibilidade apresenta inadequações.

\subsubsection{SALIÊNCIA DOS PLANOS}

Ao aprofundar a relação entre o plano da expressão e plano do conteúdo, observam-se nuances significativas na delimitação das funções, que não abordam integralmente o corpus apresentado. Por isso, propõe-se um desenvolvimento das funções utilitária e estética da linguagem como categorias polares na relação entre os planos, cujo campo intermediário se mostra pertinente para a análise.

A distinção na relevância dada aos planos em um texto define essas funções. Como se o estético fosse um acontecimento que rompesse com a previsibilidade da rotina da linguagem usual (ZILBERBERG, 2007a).

Do ponto de vista da relação entre conteúdo e expressão, há dois tipos de texto, aqueles que têm função utilitária (informar, convencer, explicar, documentar, etc.) e os que têm função estética. Se alguém ouve ou lê um texto com função utilitária, não se importa com o plano da expressão. Ao contrário, atravessa-o e vai diretamente ao conteúdo, para entender a informação. No texto com função estética, a expressão ganha relevância, pois o escritor procura não apenas dizer o mundo, mas recriá-lo nas palavras de tal sorte que importa não apenas o que se diz, mas o modo como se diz (FIORIN, 2008, p. 57).

O sensível, marcado pelo plano da expressão, sobreviria ao inteligível dos conteúdos a serem transmitidos na comunicação ordinária. E a implicação dos significados 
encadeados na leitura do texto seria desviada pela concessão do impacto dos significantes, que fariam o enunciatário interromperem seu ritmo cadenciado para fixar-se sobre o modo de expressão sígnica por meio de uma retroleitura.

Contudo a análise dessas funções nas inscrições urbanas revelou algumas exceções, pois sob essa consideração do estético, o plano do conteúdo também poderia produzir tais efeitos, como no caso da inscrição política "é proibido proibir", cujo plano do conteúdo se sobressai à repetição do adjetivo e do verbo no infinitivo. Do mesmo modo, as duas funções podem ser encontradas em um mesmo texto, dependendo da abordagem da análise, como no caso de Lady Pink, cuja mensagem aparentemente utilitária incorpora-se ao retrato produzindo um texto com função estética.

Enfim, a reflexão contida na proposta dessas funções é bastante pertinente para compreender a relação entre as modalidades de inscrições urbanas, pois se notam tendências distintas entre os movimentos de Nova Iorque e Paris. As funções estética e utilitária seriam então admitidas como tendências, melhor dizendo, direções a serem tomadas em um eixo de possíveis.

Esse tipo de consideração anteciparia uma abordagem dos planos no espaço tensivo e, antes de produzir um esquema de relação de intensidade e extensidade entre os planos, entende-se que nas inscrições urbanas a saliência dos planos possui maior pertinência. Para isso, os conceitos de Figura e Fundo desenvolvidos por Leonard Talmy (2000) são considerados a partir de seu capítulo sobre as relações semânticas frasais. Essa proposta é estendida para tratar da relação entre os planos, que poderia ser avaliada pelos mesmos critérios aplicados nas obras dos autores precedentes.

Sob os termos de Fundo e Figura, o linguista propõe um ponto de vista espacial e temporal para tratar das relações conceituais na linguagem ${ }^{45}$. Segundo ele:

A Figura é uma entidade conceitualmente flexível, cujo percurso, posição ou orientação é concebido como uma variável, pela qual apresenta questões relevantes sobre seu o valor particular.

O Fundo é uma entidade referencial, que tem uma posição estática relativa ao quadro de referência, em relação ao percurso, posição ou orientação caracterizada pela Figura ${ }^{46}$ (TALMY, 2000, p. 312).

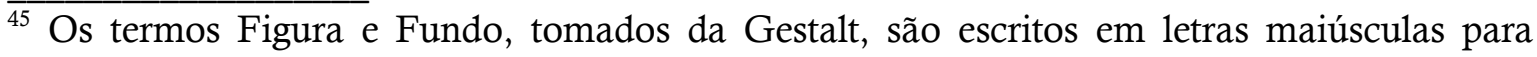
diferenciar-se do seu uso na psicologia (TALMY, 2000, p. 312).

${ }^{46}$ The Figure is a moving or conceptually movable entity whose path, site, or orientation is conceived as a variable, the particular value of which is the relevant issue.
} 
Enquanto a Figura tem "propriedades espaciais (ou temporais) desconhecidas a serem definidas", o Fundo "age como uma entidade de referência cujas propriedades conhecidas podem caracterizar as propriedades desconhecidas da Figura" (TALMY, 2000$, p. 315$)^{47}$. Nessa relação, o autor destaca algumas características, pertencentes a cada um dos conceitos, que coincidem no geral com as destacadas por Lemos (2015, p. 88) como "tendências a serem especificadas em cada contexto" encontradas na teoria Gestalt (Cadiot \& Visetti, 2001, p. 55-59 apud Lemos 2015, p. 88).

Tabela 6 - Características de Figura e Fundo

Figura

\begin{tabular}{cc}
\hline mais saliente & menos saliente \\
\hline mais recentemente presente na cena & mais familiar ou esperado \\
\hline resistente à mudança & mais variável \\
\hline mais homogêneo & menos homogêneo \\
\hline
\end{tabular}

Dentre essas características, a saliência possui um papel relevante, pois é a partir dela que serão diferenciados os planos como Figura e Fundo. Assim, as funções utilitária e estética seriam entendidas pela saliência dos planos de expressão e conteúdo em um texto. A princípio, cada função pode ser explicada pela tomada de posição de um plano como Figura. No caso da função estética, o plano da expressão seria a Figura e o plano do conteúdo o Fundo, porque ela traria homogeneidade expressiva, seria mais saliente, seria mais resistente à mudança, enquanto o plano do conteúdo variaria mais e seria menos homogêneo e teria menor destaque em prol do impacto da expressão. Mesmo que com maior variação, o conteúdo instaurado gera maior previsibilidade em comparação aos elementos salientes da expressão, que dentro do discurso poético produz inovações constantes da forma de expressão.

Igualmente, na função utilitária, haveria a saliência do plano do conteúdo estabelecido como Figura, pois a expressão seria mais variável e menos homogênea,

The Ground is a reference entity, one that has a stationary setting relative to a reference frame, with respect to which the Figure's path, site, or orientation is characterized.

${ }^{47}$ Figure: Has unknown spatial (or temporal) properties to be determined. Ground: acts as a reference entity, having known properties that can characterize the Figure's unknowns. 
como no caso da frase comum, que possui uma notável diferenciação dos sons - sem aquela homogeneização fonética que ocorre na poesia. $\mathrm{O}$ fluxo sonoro da frase levaria aos significados, mais relevantes para a comunicação.

Dessa forma, a mudança das funções para os conceitos de Figura e Fundo só ganharia pertinência no seu desenvolvimento gradativo. Assim, a saliência seria um elemento agregador das outras características, hierarquicamente superior, pois ao considerar a saliência do plano, seria pressuposta sua homogeneidade, sua resistência à mudança etc., ou seja, a posição de Figura ou Fundo para a presente investigação seria constituída da gradação da saliência de cada plano.

Embora seja empregado o plano cartesiano para tratar dessa relação e seja alinhado o eixo da extensidade ao plano do conteúdo e o eixo da intensidade ao plano da expressão, que dentro da área semiótica é diretamente associado ao campo tensivo, não se trata necessariamente da aplicação sistemática da teoria tensiva para lidar com os planos. O modelo percorre a reflexão da tese e por isso é escolhido como o mais indicado para abordar esse tipo de relação gradativa. A proposta de Talmy (2000) conduz prioritariamente essa parte da reflexão, que é adaptada para um esquema de representação mais conveniente à proposta desta investigação.

Então, um maior nível de saliência seria associado à Figura e contrariamente, o Fundo seria percebido pelo seu menor nível de saliência. Nessa configuração, as funções utilitária e estética constituem-se respectivamente por uma maior saliência do plano do conteúdo ou do plano da expressão, cujo regime exclusivo na tensividade explicaria suas direções. 
Esquema 12- Relação entre os planos por sua saliência

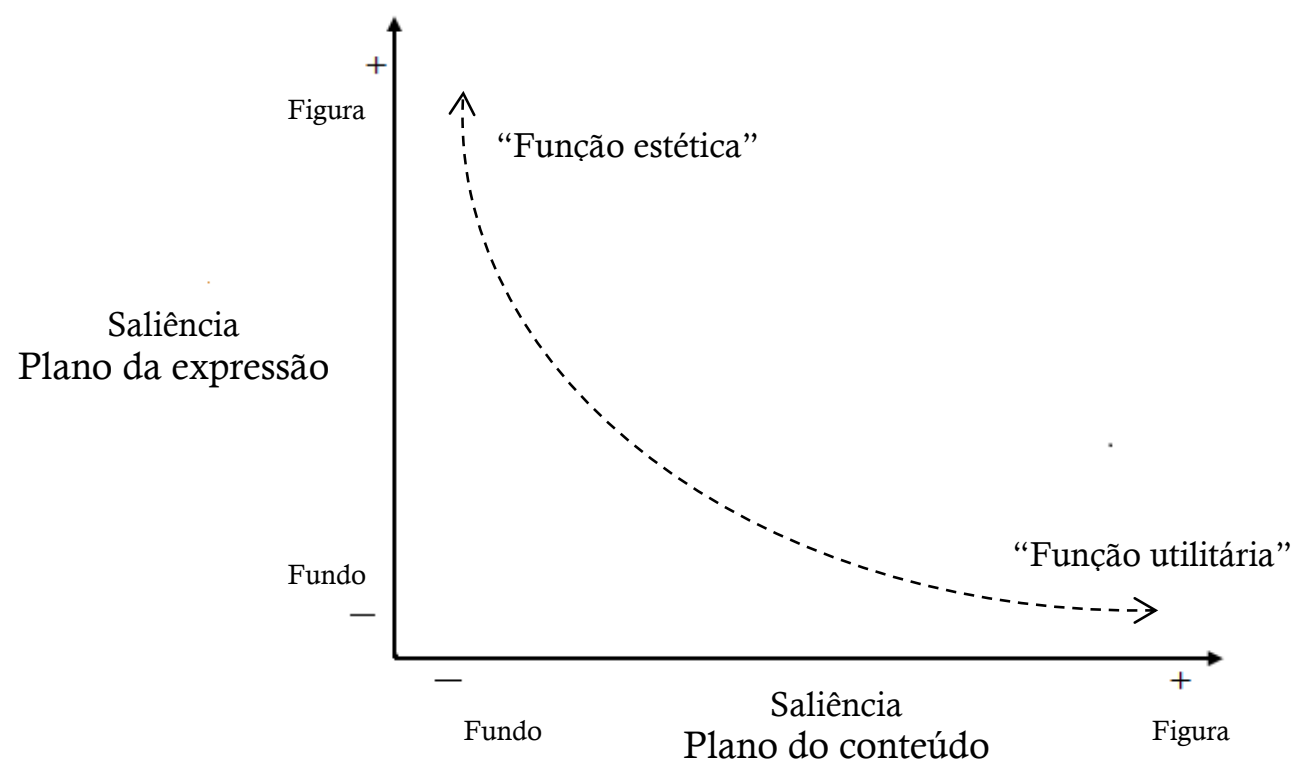

Os termos foram colocados em aspas, porque seria possível uma função estética com o plano do conteúdo saliente, mas por que não uma função utilitária com a saliência do plano da expressão? No primeiro caso, a inscrição política parisiense revelou um impacto estético do seu plano do conteúdo, mais que sua simples repetição de palavras. Na literatura, o conceptualismo barroco investe fortemente em uma estética de conteúdos. Já no segundo caso, a função fática tratada por Jakobson (2005, p. 126) em sua proposta de funções da linguagem abordaria esse ponto de vista, o que seria o "Alô" e o "O.k." senão uma função utilitária do plano da expressão. Então, percebe-se que a saliência entre os planos não poderia definir a função utilitária ou estética.

Pela análise das inscrições urbanas, foram observadas nuances na saliência dos planos que escapariam às determinações fixas das funções. Portanto, ao colocá-las em extremos de uma escala, valorizam-se as posições intermediárias identificadas nas problematizações dos exemplos anteriormente analisados. Vistas como tendências, as "funções" podem ser entendidas por meio de um fluxo de ascendências e descendências da saliência dos planos. Antes de entrar nessa perspectiva caracteristicamente tensiva, segue-se com as relações entre os planos sob a perspectiva Figura/Fundo para verificar o semissimbolismo e o símbolo. 
Enquanto as funções utilitária e estética destacam um dos planos, o semissimbolismo produz tal correspondência entre eles que a saliência incide sobre os dois planos. Dessa forma, as categorias pareadas do plano do conteúdo e plano da expressão tornam-se Figura em relação às outras fora do semissimbolismo. É como se ocorresse uma divisão dentro da função semiótica, na qual uma parte do texto seria destacada, devido às categorias privilegiadas entre os dois planos na formação semissimbólica.

Do regime exclusivo que marcava as relações simples entre os planos, ou o plano do conteúdo ou o plano da expressão seriam salientes. Nesse processo, o regime participativo rege a relação. No entanto é necessário apontar que dentro desse regime participativo encontra-se um regime inverso na relação entre os planos, pois para salientar o semissimbolismo foi necessário previamente distingui-lo das outras relações não semissimbólicas, ou seja, as categorias excluídas do semissimbolismo tornar-seiam menos salientes.

Esse processo não abordaria individualmente os planos, mas destacaria determinadas relações. Ao mesmo tempo em que plano do conteúdo e plano da expressão integram o conceito de Figura, formam também o conceito de Fundo. Como essa relação de saliência é parcial no texto, haveria um grau mais saliente que seria o do símbolo, cujos planos atingiriam uma totalidade.

O caso do símbolo é bastante particular porque não se aplicaria a distinção entre Figura e Fundo, quer dizer, a saliência dos dois planos seria integral, dessa forma, a distinção entre os conceitos seria neutralizada. O símbolo é Figura e Fundo, já que a univocidade entre os planos é recíproca. Talmy (2000, p. 313) já previa a complexificação de Figura e Fundo para produzir uma sobreposição, no entanto, ele não neutraliza essa configuração, apenas a recoloca em outro nível de pertinência mantendo a dualidade.

A combinação entre os objetos linguísticos Figura e Fundo funciona como uma figura psicológica, enquanto seu contexto funciona como um fundo psicológico. Sob essa interpretação, o conjunto de relações psicológicas de figura/fundo é sobreposto a outro. O objeto Figura é a figura psicológica para o objeto Fundo entendido como fundo psicológico $^{48}$ (TALMY, 2000, p. 313, tradução própria). ${ }_{48}^{[. . .]}$the combination of the linguistic Figure object and Ground object together functions as a
psychological figure, while the background now functions as a psychological ground. Under this 
Devido à adequação do objeto de análise e, sobretudo, às diferenças inerentes às duas abordagens, a base de complexificação entre Figura e Fundo foi mantida e adaptada para o caso do símbolo, que, por não possuir plano do conteúdo, liga-se inteiramente à expressão, apagando suas diferenças: o conteúdo do símbolo é sua expressão e vice-versa. Como a abordagem da relação entre os planos por meio da semântica de Talmy (2000) não possui uma correspondência direta, pois ela é fruto da intermediação da tese de Lemos (2015) nesta proposta, acredita-se que talvez essa neutralização pudesse ser vista no domínio da frase, porém, trata-se mais uma vez de especulação.

Retornando às relações entre planos, o símbolo funcionaria como uma integração do objeto figura e fundo, mas sem haver um contexto psicológico sobreposto. Diluir-se-ia essa distinção de objetos para formar um único objeto, que poderia ser visto tanto como figura quanto como fundo. Para esclarecer melhor essas relações e antes de esquematizá-las no regime participativo, coloca-se uma ilustração apresentando suas diferenças. Para essa representação, foi escolhida arbitrariamente a forma do quadrado baseada nas pinturas de Joseph Albers, em que a cor preta representa o plano da expressão, a cor branca o plano do conteúdo, sem considerar evidentemente o contorno externo das linhas pretas que demarcam a forma quadrado.

Figura 60 - Relação entre os planos como Figura e Fundo
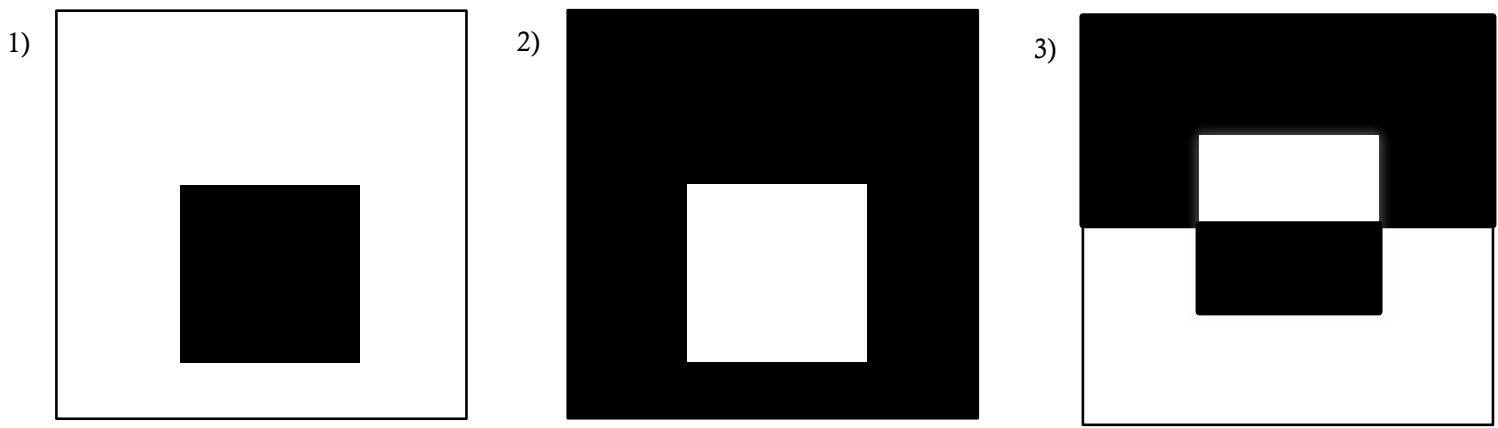

O quadrado número um representa a função estética, cujo plano da expressão é mais saliente revelando seu papel de Figura, em cor preta. No exemplo número 2, a função utilitária destaca o plano do conteúdo, em cor branca, cujo Fundo é

interpretation, one set of psychological figure/ground relations is embedded within another. The Figure object is the psychological figure to the Ground object as the psychological ground. 
constituído pelo plano da expressão. Seguindo com a série, o terceiro quadrado forma o semissimbolismo, que salienta a relação categórica nos dois planos, consequentemente, as outras relações excluídas constituem o Fundo.

O quarto exemplo encontra na estampa Chevron um modo de indeterminação entre Figura e Fundo. Ao observar a Figura, é difícil afirmar se são linhas brancas em zig-zag sobre um fundo negro ou vice-versa.

Figura 61 - Expressão e conteúdo no símbolo

4)

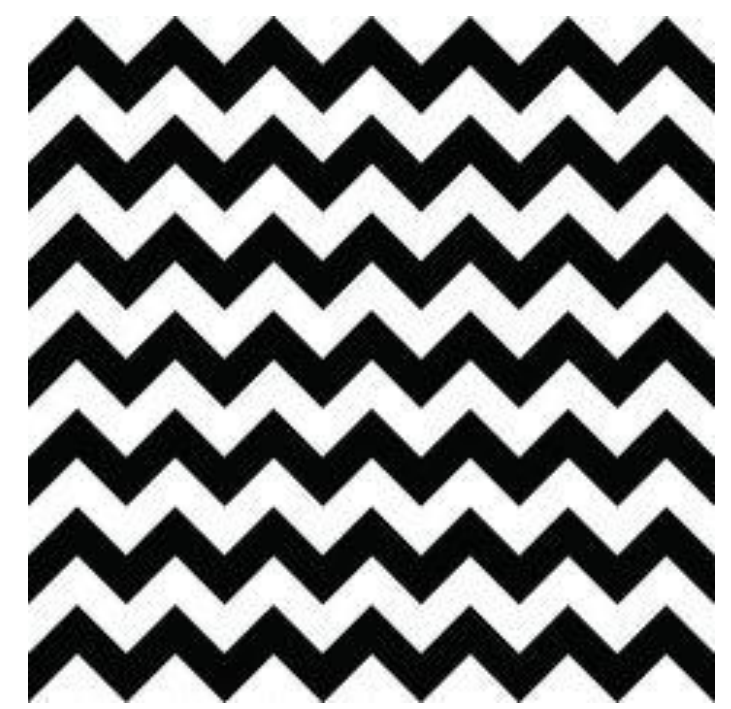

Primeiramente, o símbolo problematiza a relação Figura e Fundo, devido à alta saliência tanto na expressão quanto no conteúdo. Sua conformidade é levada para ilustração por meio do matiz na demarcação. Por outro lado, o símbolo pode ser configurado como Fundo, dependendo de seu baixo nível de saliência.

Ora, como já visto anteriormente, o símbolo é caracterizado pela concentração de significados até atingir uma paridade de "um para um" com a expressão, concedendo a essa formação uma alta saliência. No caminho oposto, a pichação não alcançaria a mesma condição de símbolo, justamente por sua falta de saliência ocasionada pela inconsistência temporal. Por funcionar segundo o mesmo sistema, a pichação poderia ser considerada um símbolo não saliente: exclusivamente Fundo.

Essa variação quantitativa de aumentos e diminuições na percepção da saliência dos planos pode ser compreendida pela sintaxe tensiva. As dimensões ascendentes e descendentes regulariam o movimento entre Figura e Fundo. A 
dimensão ascendente caracterizaria o plano do conteúdo na função utilitária, o plano da expressão na função estética, a junção categorial no semissimbolismo e os planos da expressão e do conteúdo no símbolo, enquanto a dimensão descendente marcaria aa pichação no sistema simbólico e, contrariamente, o plano da expressão na função utilitária, o plano do conteúdo na função estética e as categorias não pertencentes ao semissimbolismo.

A ascendência é constituída de categorias e unidades que marcam um percurso que parte da diminuição do menos para chegar ao aumento do mais, pois ao pensar em um processo "negativo" que se torna "positivo", o primeiro a ser feito é tirar o menos para inserir o mais. Nessa mesma perspectiva, encontra-se a dimensão descendente. Ela retira o excesso de mais para colocar menos e com isso dirigir um percurso do decréscimo.

Portanto, a saliência seria quantificada por seus movimentos de mais e menos formadores de Figura e Fundo. Coloca-se primeiramente o esquema de ascendência e descendência individualmente para, em seguida, inseri-lo na representação do espaço tensivo. Em uma leitura vertical, observam-se três linhas ou três níveis em cada esquema (separados por colchetes), são eles: a dimensão, as categorias e as unidades (ZILBERBERG, 2011b, p. 60) ${ }^{49}$. Em uma leitura horizontal, observa-se a direção, cujos níveis vão determinar maior ou menor segmentação dos graus. Na ascendência:

Esquema 13 - Dimensão ascendente

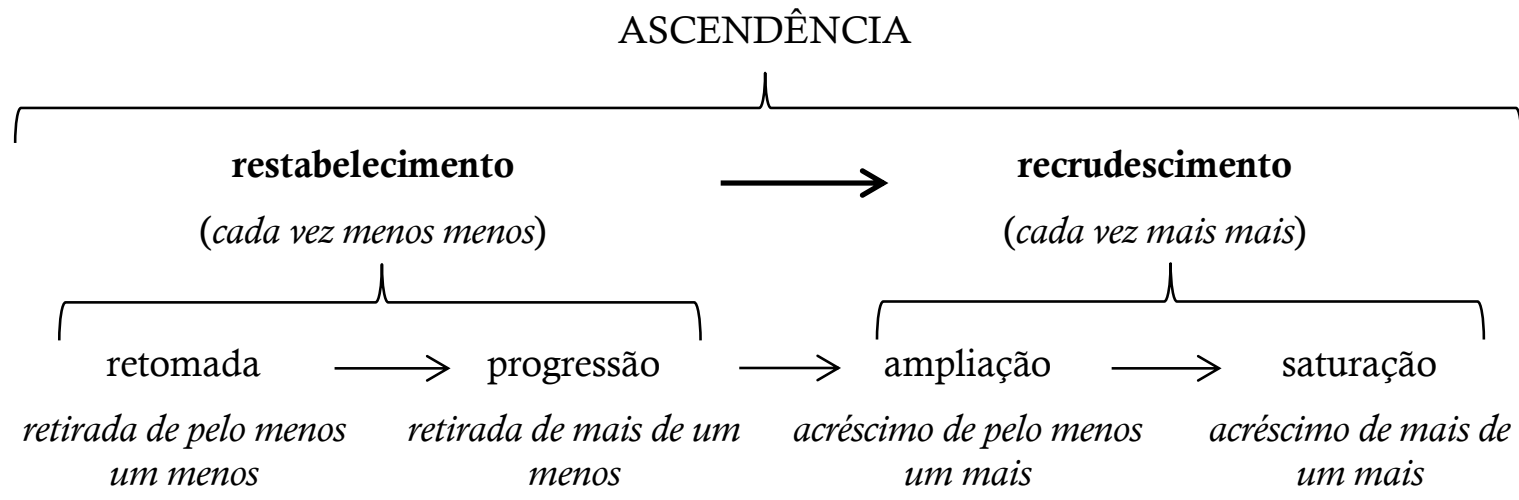

\footnotetext{
${ }^{49}$ A reelaboração da tabela encontrada em Zilberberg (2011), já citada nesta tese, tem uma finalidade didática, a visualização dos percursos tensivos, e uma finalidade prática, agilidade da leitura, evitando a busca da tabela citada em páginas anteriores.
} 
O mesmo percurso é encontrado na dimensão descendente. Respeitando a sequência, a unidade seguinte à saturação do esquema ascendente (acima) levaria à sua continuação pela unidade moderação (esquema abaixo). No entanto as direções podem ser interrompidas e invertidas em qualquer unidade dos percursos dos esquemas seis e sete. Desse modo:

\section{Esquema 14 - Dimensão descendente}

\section{DESCENDÊNCIA}

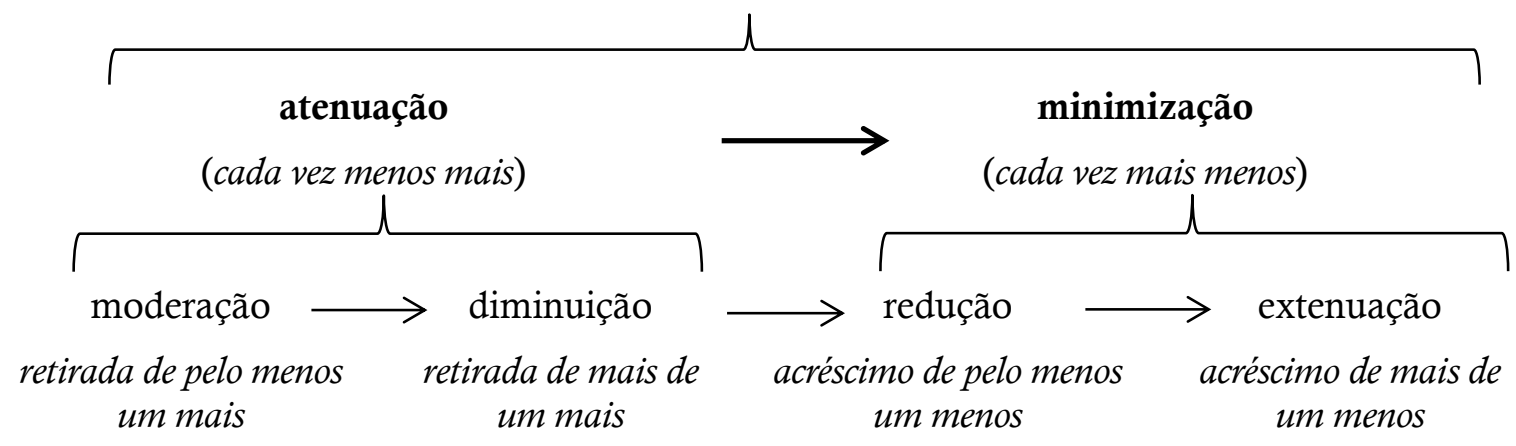

Esses dois processos, como já foi visto, são complementares. Em uma lógica implicativa, a unidade posterior à saturação, na dimensão ascendente, é a moderação, implicando uma mudança de sua direção. Assim como a unidade posterior à extenuação, na dimensão descendente, é a retomada, implicando novamente em uma mudança de direção. Essas relações ainda não foram dispostas em um gráfico tensivo, pois se encontram dificuldades para representar visualmente essas variações quantitativas nos eixos. Seguindo a proposta feita nos capítulos anteriores, empregamse somente as unidades nos eixos e abrevia-se o nome de cada uma delas para constituir à seguinte configuração do esquema tensivo: 


\section{Esquema 15 - Saliência nos planos}

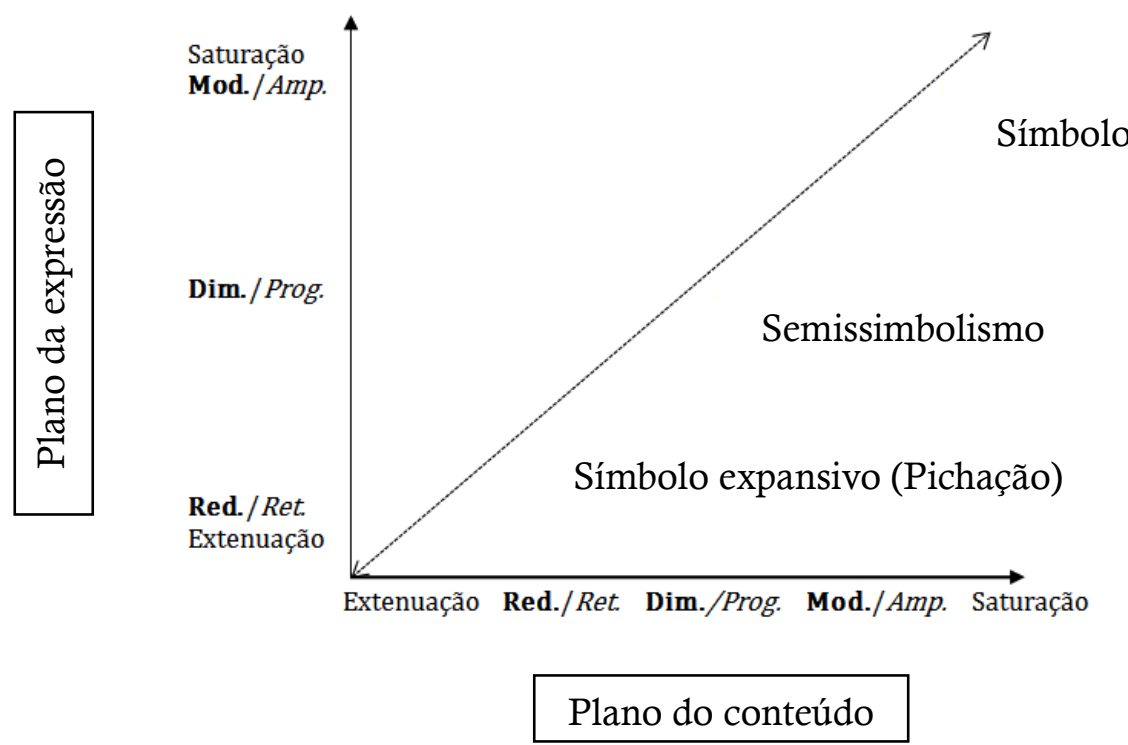

Embora o termo pichação contraste com os outros termos estruturais, o objetivo é mostrar as relações em função dos objetos de análise. Como o sistema simbólico e semissimbólico já estão consolidados e o tipo de sistema encontrado na pichação está em processo, não seria possível criar uma definição para uma prática ainda não estabelecida. Se o fator tempo mostrar-se adequado para a compreensão da estrutura simbólica, a pichação seria um caso de produção de símbolo por expansão e talvez houvesse outros objetos constituídos da mesma forma. Somente o tempo poderá revelar se a pichação se tornaria um símbolo. Segundo a presente investigação, pode-se afirmar que há uma tendência para isso.

Demonstra-se, então, uma síntese dos "lugares" no gráfico tensivo, no qual se encontram os exemplos até então discutidos nas inscrições urbanas. 
Esquema 16 - Panorama dos exemplos analisados

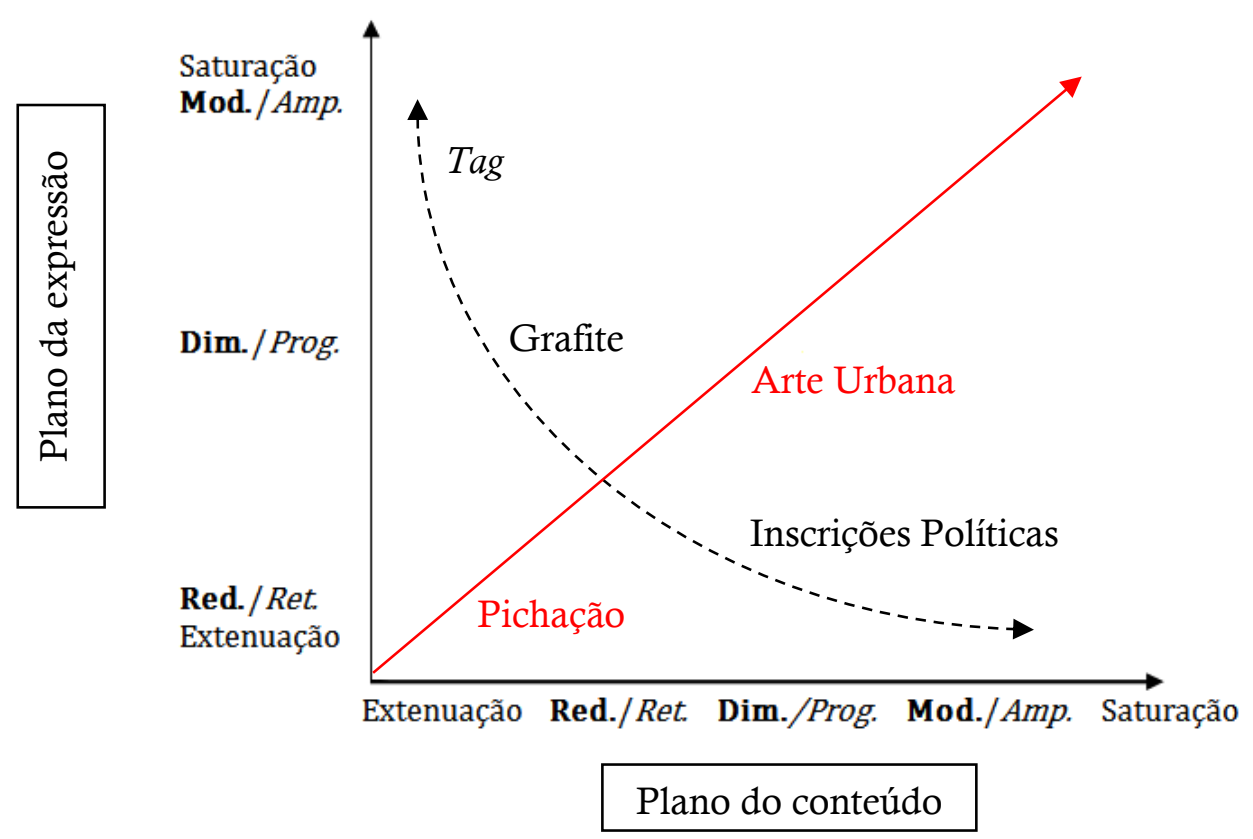

Portanto, a linha de reflexão do capítulo está voltada para as inscrições urbanas e busca simplesmente discutir os modelos da semiótica que não satisfazem inteiramente as exigências do objeto. $\mathrm{O}$ conceito de símbolo foi expandido, a relação entre os planos foi graduada e os conceitos de função estética e utilitária foram problematizados. Viu-se que, apesar de a terminologia não abarcar completamente os objetos, o sentido é mantido, pois os objetos correspondem exatamente às reflexões linguísticas. A inadequação de alguns objetos ao modelo só traz especificações que desenvolvem e reafirmam a teoria.

\subsubsection{FIGURA E FUNDO NO PROCESSO SIMBÓLICO}

A proposta de formulação do sistema de símbolo já foi discutida anteriormente e explicada por meio das concentrações e expansões do plano do conteúdo impulsionadas pela repetição. A semiótica tensiva contribuiu para a compreensão dos 
processos com os conceitos da lógica implicativa e concessiva, além da quantificação estabelecida pelos movimentos de ascendência e descendência. Enfim, acredita-se que a ampliação da abordagem do sistema de símbolo pela integração da repetição e do tempo tenha sido esclarecedora.

Contudo, ao continuar a investigação da relação entre os planos, iniciou-se com outra proposta baseada da semântica de Talmy (2000). Essa abordagem considera a relação entre os planos de forma sistêmica, mas sem perder de vista o objeto. Em outras palavras, seria uma teoria do objeto, em que sua análise traria contribuições teóricas, sem integrar uma vertente de aplicação de um modelo teórico para sua validação. A aplicação existe, mas com certo direcionamento para formular questões teóricas, sem ter propriamente um objeto de estudo epistemológico ${ }^{50}$.

Por isso, os conceitos de Figura e Fundo foram aplicados em função de uma sistematização, mas possuem pertinência no tratamento do processo de formação do símbolo, ainda que já tenham sido devidamente explorados. O encadeamento da repetição no tempo do símbolo e da pichação poderia ser visto sob o enfoque da semântica de Talmy (2000) para que a mudança de ponto de vista possa esclarecer ainda mais esse processo. Portanto, faz-se um breve parêntesis para retornar ao processo de repetição que contribui para a formação do símbolo desdobrando-o pelo ponto de vista de Figura e Fundo.

Assim, no exemplo do comunismo e do nazismo que são constituídos pelo sistema simbólico, a repetição do emblema, que se difunde na variação de conteúdo até alcançar a concentração necessária para a criação do símbolo, pode ser entendida como um processo de alternância entre Figura e Fundo. A cada repetição do emblema forma-se uma Figura que é transposta para a condição de Fundo e o que era mais saliente, mais homogêneo e mais resistente à mudança passa a ser menos saliente mais variável e menos homogêneo. Quando a repetição gera a concentração necessária, sua sequência até então normal (relativa à norma) passa a integrar junto com o fundo uma Figura única em uma lógica implicativa, o símbolo: saliente, homogêneo e invariável.

Essa rearticulação da Figura que se converte em Fundo, devido às suas relações, é baseada na linearidade do discurso, cujas frases ou partes se modificam

\footnotetext{
${ }^{50}$ Informação verbal obtida de uma conversa com a professora Dra. Carolina Lindenberg Lemos (2016) sobre as produções acadêmicas em Semiótica no Brasil.
} 
mutuamente em razão de sua posição na cadeia. Lemos (2015), ao tratar de um anúncio publicitário, mostra como esse intercâmbio ocorre na linearidade.

\begin{abstract}
Assim, ao passar ao estatuto de fundo, de suporte para a figura que virá, o primeiro termo torna-se mais variável, e sua interpretação é passível de flutuações. A entrada do segundo termo desloca o sentido do primeiro (LEMOS, 2015, p. 89).
\end{abstract}

Os exemplos mostram que a apreensão de um emblema seria considerada uma Figura, até a ocorrência de outro emblema, pois se trata de uma repetição, que "deslocaria" o primeiro para o Fundo e assim sucessivamente. Até que em determinado momento, devido ao excesso de repetição durante certo tempo, o Fundo mais familiar e esperado é "projetado para frente" porque a Figura recém-apreendida não mais se difere dele, ambos passam a significar o mesmo. Ocorre, então, uma junção entre os dois termos, por causa da extenuação do conteúdo formador do símbolo.

No exemplo da pichação, ocorre um processo semelhante, mas pelas vias da expansão de conteúdo. O picho apreendido pelo enunciatário é considerado Figura, que logo será seguido por outro picho deslocando o primeiro para o Fundo e tornando-se Figura. Porém essa sequência não produz sentido, já que a assinatura é indecifrável para os enunciatários não competentes e não reconhecida pelos competentes. Logo, a diferenciação entre Figura e Fundo seria entre um picho recentemente posto em cena e outro que fica potencializado. Essa conexão da série só seria realizada quando houvesse um acúmulo suficiente da repetição para tornar familiares todas às repetições do picho ligadas a uma identidade (Fundo).

Mais uma vez, Figura e Fundo seriam correlatas. Entretanto não haveria tempo de repetição suficiente para juntá-los. Como se esse processo pudesse ser continuado por dois percursos: a expansão do conteúdo seguiria e o picho seria vinculado a outros conteúdos, demarcando nitidamente a relação Figura e Fundo, ou sua repetição poderia gerar uma conformidade entre expressão e conteúdo, caracterizando o símbolo. Alguns pichadores, por sua exposição midiática, poderiam ter seus pichos considerados como símbolos de sua própria identidade, mas acredita-se que essa afirmação é frágil devido a sua inconsistência de repetição no tempo. 
A pichação seria um caso de símbolo em progresso, por isso foi colocada em uma lógica implicativa com pouca saliência. Sua junção de Figura e Fundo seria saliente conforme a repetição do picho fosse mantida ao longo do tempo, colocando o conteúdo identitário no nível de símbolo.

Lembrando que, apesar de o semissimbolismo ocupar um lugar intermediário no esquema tensivo, entre o símbolo e a pichação, não significa que ele é uma involução do primeiro e uma evolução do segundo, sua posição somente descreve uma escala de saliência entre os planos, cujas estruturas possuem características próprias e distintas uma das outras, como já foi explicado.

Assim, a proposta de reformular as relações entre os planos de conteúdo e plano da expressão partiu das exigências do próprio objeto, que, segundo a história das inscrições urbanas, valorizaria um dos planos em diferentes modalidades. As modalidades ligadas à Nova Iorque dariam maior relevância ao plano da expressão, enquanto as de Paris desenvolveriam o plano do conteúdo.

Contudo percebe-se que ambas as "escolas" de inscrições urbanas oscilam em relação à saliência dos planos. Essa tendência distintiva entre Paris e Nova Iorque provavelmente deve-se ao maior emprego da semiótica verbal pela "escola de Paris" e da semiótica plástica pela "escola" de Nova Iorque, produzindo um efeito de "função estética" e "função utilitária". Mesmo assim, verifica-se que as definições desses termos não abarcam integralmente as variedades de saliência entre os planos.

De fato, as inscrições relativas ao Maio de 68 utilizam com maior intensidade a semiótica verbal, mas dando saliência a cada plano de formas diversas, igualmente, as inscrições ligadas ao grafite nova-iorquino valorizam a plasticidade, mesmo ao empregar a semiótica verbal. Esse modo de produção influenciou as diversas modalidades de inscrições urbanas, basta ver os desdobramentos dessa evolução histórica nas obras de Keith Haring e Miss.Tic, cada um com características de uma tendência. Nesta um desenvolvimento do Maio de 68, naquele uma elaboração das propostas de Nova Iorque. Porém, de acordo com a história das inscrições urbanas no capítulo 1, essas escolas são diluídas e mescladas ao longo do tempo. Um exemplo dessa enorme variação resultante do desenvolvimento histórico é a obra de Banksy, pois possui um lado político ligado ao Maio de 68 e a Blek le Rat, um lado fortemente marcado pelas normas da arte urbana e por fim, a transgressão, as técnicas de 
produção rápidas e o uso do suporte desenvolvidos pelas modalidades descendentes da tag.

Portanto, para pensar em termos históricos, propôs-se um estudo sobre as relações sociais que integrariam a formação das modalidades e sua repercussão nos textos, por meio da saliência entre os planos e pela repetição no tempo. Deixa-se um instrumental para análise das obras em si, tendo em conta os fluxos sociais e o uso dos planos nos textos, pois essa demarcação didático-histórica, cara a uma parte dos historiadores da arte, esconde especificidades das obras, enquadradas em movimentos artísticos que raramente dão conta da análise de uma obra.

A ideia geral foi mostrar, com base no conceito de norma, as tensões sociais produtoras de modalidades na diacronia e ao serem investigadas com maior profundidade, essas modalidades apontaram suas próprias tensões, destacadas nesta proposta pela saliência entre os planos. A tentativa de iluminar os processos estruturais na história das inscrições urbanas pautou o ponto de vista da tese e por isso mesmo apagou potenciais linhas de investigação, por exemplo, a análise detida de textos específicos, que podem trazer um desenvolvimento do modelo.

Ao tratar das relações sociais e da saliência entre os planos, ao longo da história das inscrições urbanas, foram postas em evidência duas abordagens calcadas em extremos: a cena enunciativa e o texto e não seria ousado dizer, da transcendência à imanência. Desse modo, segue-se a investigação para considerar um elemento que possa intermediar esses dois campos: o suporte. 


\section{SUPORTE}

Em cada bloco de mármore vejo uma estátua; vejo-a tão claramente como se estivesse na minha frente, moldada e perfeita na pose e no efeito. Tenho apenas de desbastar as paredes brutas que aprisionam a adorável aparição para revelá-la a outros olhos como os meus já a veem.

Michelangelo 
A partir da proposta de análise das imagens digitais de Dondero (DONDERO e REYES, 2016), pautada no percurso gerativo do plano da expressão (FONTANILLE, 2015), busca-se explicar a relação entre os três níveis de análise que se estabelecem ao longo da tese: a prática e o texto, que já foram desenvolvidos nos capítulos anteriores, e o objeto, assunto a ser tratado neste capítulo. A célebre citação do artista renascentista italiano sintetiza muito bem a abordagem que se segue sobre a consideração do suporte nos estudos de semiótica visual (ver epígrafe).

O trabalho de Michelangelo como escultor é tirar o excesso de material bruto, que oculta o aparecimento da forma. Assim, a pedra enquanto suporte material é uma fonte de possibilidades para a construção da escultura e o artista intervém na seleção e na intensificação das formas. Essa domesticação do material para a produção da escultura estaria no nível do objeto, de acordo com a proposta da semiótica das práticas.

Fontanille (2015) estipulou um modelo de análise, chamado percurso gerativo do plano da expressão, que abordasse a produção de sentido no nível da cultura. Constituído de seis níveis de pertinência, o modelo possibilita uma abordagem distribucional, denominada detalhamento, que tanto se concentra nas relações estabelecidas em um mesmo nível, quanto também permite uma análise integrativa, denominada realçamento, cuja função está na relação entre os níveis.

De início, e na falta de um inventário mais exaustivo, essa estruturação do mundo da expressão semiótica em seis planos de imanência e de pertinência diferentes apresenta-se como uma descrição da estrutura semiótica das culturas. Entre os signos e as formas de vida, ela propõe de fato que se considere o conjunto dos níveis pertinentes nos quais as significações culturais podem se exprimir (FONTANILLE, 2008, p. 20).

A hierarquia canônica entre os níveis possui um percurso ascendente, das figuras-signos às formas de vida, no entanto, um percurso analítico descendente também é previsto. No percurso ascendente, verifica-se um movimento de expansão, já que o nível superior, desdobrando-se em novas dimensões, engloba o nível inferior. No percurso descendente, há um movimento de concentração, no qual o nível inferior desconsidera alguns traços pertinentes do nível superior. Essa integração entre os níveis pode ser considerada de modo contínuo, quando cada nível for apreciado consecutivamente, ou de maneira descontínua, quando houver síncopes no percurso. 
Cada nível é dividido em um tipo de experiência, uma instância formal e uma instância material, mas ao mesmo tempo em que há uma preservação da imanência no detalhamento, também há sua transcendência no realçamento, porque "os elementos sensíveis e materiais de um nível inferior só adquirem significação quando integrados à instância formal do nível superior" (PRADO, 2010). Então, o que é forma em um nível pode tornar-se substância em outro nível. "Em outros termos, é substância aquilo que é organizado e é forma aquilo que organiza. Por sua vez, uma forma pode ser organizada por outra forma e assim tornar-se substância do ponto de vista desta nova forma" (DONDERO e REYES, 2016, p. 5) ${ }^{51}$. Assim, pensa-se na apresentação do modelo preservando os movimentos ascendentes e descendentes da própria espacialidade da tabela a seguir. Por isso inverteu-se a disposição gráfica dos níveis comumente vista na bibliografia sobre o assunto. Sob o viés do detalhamento, o negrito colocado na coluna das interfaces define a substância e o itálico a forma.

Tabela 7 - Adaptação do percurso gerativo do plano da expressão

\begin{tabular}{|c|c|c|}
\hline TIPO DE EXPERIENCIA & $\begin{array}{l}\text { INSTÂNCIAS } \\
\text { FORMAIS }\end{array}$ & INTERFACES \\
\hline \multirow{2}{*}{ Ethos e comportamento } & \multirow[t]{2}{*}{ Formas de vida } & \\
\hline & & Estilos estratégicos \\
\hline \multirow[b]{2}{*}{ Conjuntura } & \multirow[b]{2}{*}{ Estratégias } & Iconização dos comportamentos estratégicos \\
\hline & & Gestão estratégica das práticas \\
\hline \multirow[b]{2}{*}{ Prática } & \multirow{2}{*}{ Cenas da prática } & Processo de acomodação \\
\hline & & Cena predicativa \\
\hline \multirow{2}{*}{ Corporeidade } & \multirow{2}{*}{ Objetos } & Morfologia da práxis \\
\hline & & Suporte formal de inscrição \\
\hline \multirow{2}{*}{$\begin{array}{l}\text { Coerência e coesão } \\
\text { interpretativas }\end{array}$} & \multirow{2}{*}{ Textos-enunciados } & Dispositivo de enunciação/inscrição \\
\hline & & Isotopias figurativas da expressão \\
\hline \multirow{2}{*}{ Figuratividade } & \multirow[b]{2}{*}{ signos } & Formantes recorrentes \\
\hline & & \\
\hline
\end{tabular}

(FONTANILLE, 2015, p. 38)

A partir desse modelo, Dondero e Reyes (2016) irão deter-se nas instâncias formais dos objetos. Uma reavaliação do conceito de forma é colocada pelos autores,

\footnotetext{
${ }^{51}$ En d'autres termes, est substance ce qui est organisé, est forme ce qui organise. Une forme peut être à son tour organisée par une autre forme et ainsi devenir substance du point de vue de cette nouvelle forme.
} 
devido à impossibilidade de considerar o suporte dentro de uma perspectiva da semiótica tradicional, pois ao abordar elementos materiais como integrantes da produção de sentido, o primado da forma seria problematizado.

Os conceitos sobre forma buscados na obra de Jean-Marie Floch (2014) e as negligências analíticas de Felix Thürlemann (1982) com relação à textura nas obras de Paul Klee evidenciam a manutenção das bases imanentes da semiótica, que impediam um desenvolvimento da então incipiente semiótica visual a respeito do suporte na significação de obras plásticas.

Segundo Floch (2014), a invariação é um elemento estrutural na concepção da forma, pois ela "é a organização invariante e puramente relacional de um plano que articula a matéria sensível ou a matéria conceitual de modo a produzir a significação. Assim, é a forma que, para a semiótica, é significativa" (FLOCH, 2014, p. 191) ${ }^{52}$. Com isso, elimina-se todo elemento material, já que apesar das mudanças de substância, a forma é aquilo que não varia. Essa noção tem um lugar privilegiado na teoria do conhecimento da tradição aristotélica, já que "oposta à matéria que ela enforma, no ato mesmo em que 'forma' o objeto cognoscível, a forma é o que garante a sua permanência e identidade" (GREIMAS e COURTÉS, 2008, p. 218).

Desse modo, a relação entre categorias eidéticas, cromáticas e topológicas ganha relevância nas análises de semiótica visual, porque elas são identificadas como as constituintes mais elementares no plano da expressão, que, vinculadas comutativamente a categorias da forma do conteúdo, produzem o semissimbolismo. Nessas relações estabelecidas entre a forma da expressão e a forma do conteúdo, que não implicam necessariamente o semissimbolismo, Thürlemann vai analisar a obra de Paul Klee, mas desconsiderando as inserções materiais na obra do artista.

"Blumen-Mythos" é pintada sobre um suporte de gaze com fios
frouxos, tensionados, com ligeiros desvios, dispostos paralelamente
aos lados do retângulo. O efeito desse filete que cobre toda a
superfície pode ser considerado como um reforço do jogo dos eixos
paralelos, mas esta "regularidade irregular" agrega, sobretudo, um
efeito "granulado" à pintura. Nossa análise, limitando-se somente ao
objeto, é forçada a negligenciar esse efeito e a considerá-lo como

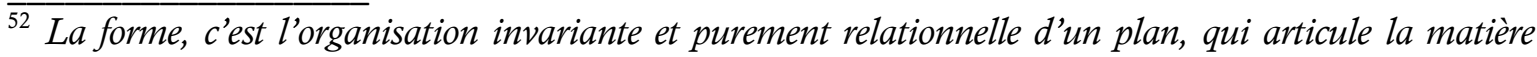
sensible ou la matière conceptuelle en produisant ainsi de la signification. 
pertencente à substância da expressão ${ }^{53}$ (THÜRLEMAN, 1979, p. 22).

Essa decisão, em consonância com o conceito clássico de forma, limita as potencialidades de compreensão do quadro, que explora relações entre forma e substância por meio da textura da superfície.

As três categorias plásticas (topológica, cromática, eidética) são apenas um meio provisório para esclarecer uma primeira organização opositiva entre zonas e subzonas da imagem, mas elas certamente não podem explicar por si mesmas a consistência das formas nem sua estética. O que falta nessa teorização é a abordagem da qualidade do suporte - por exemplo, quando tratamos da intermidialidade, a questão coloca-se de maneira decisiva ${ }^{54}$ (DONDERO e REYES, 2016, p. 4).

Essa preservação do conceito de forma, como aponta Dondero e Reyes (2016), encontra-se também na Gestalt, que diferentemente de um viés estruturalista, permite uma abertura para a inserção da matéria como fator significativo na compreensão de textos. A forma seria uma configuração transponível a diferentes suportes e substâncias, porém submetidas a determinadas coerções: "essas 'coerções específicas' dependem dos suportes das formas" (DONDERO e REYES, 2016, p. 3). Nessa linha de raciocínio, a pesquisadora italiana vai explicar o porquê de a teoria constituída por Greimas deixar de lado as investigações sobre a substância no plano da expressão (DONDERO, 2016). A princípio, a semiótica pautou sua pesquisa em textos verbais, cuja condição invariante da forma é válida para as análises. Ao mudar a edição de um romance - sua encadernação, estilo tipográfico, cor da tinta etc. - não se altera a significação da obra. Analisar o poema "Para Ana Flor" de Kurt Schwitters, seja em uma edição de luxo, seja em uma edição popular, não mudaria o sentido do texto,

\footnotetext{
$\overline{53}$ "Blumen-Mythos» est peint sur un support de gaze à fils lâches, tendus, avec de légères déviations, parallèlement aux côtés du rectangle. L'effet de ce filet qui couvre toute la surface peut être considéré comme un renforcement $d u$ jeu des axes parallèles; mais cette "régularité irrégulière » ajoute surtout un effet de "grain" à la peinture. Notre analyse, se limitant à l'objet clos, est forcée de négliger cet effet et de le considérer comme relevant de la substance de l'expression.

${ }^{54}$ Ces trois catégories plastiques (topologique, chromatique, eidétique) ne sont qu'un moyen provisoire pour éclairer une première organisation oppositive entre des zones et sous-zones de l'image mais elles ne peuvent certainement pas, à elles seules, expliquer la consistance des formes ni leur esthétique. Ce qui manque dans le cadre de cette théorisation est la prise en compte de la qualité du support; par exemple, quand on s'occupe d'intermédialité, la question se pose de manière décisive.
} 
desde que respeitada a escrita original. A essa configuração da linguagem verbal principalmente em textos literários, dá-se o nome de sistema alográfico.

A identidade ortográfica é o meio para distinguir as propriedades constitutivas da obra e as propriedades contingentes (é o que se denomina sistema alográfico, que possui um alfabeto de signos disjuntos e que possui uma notação) $)^{55}$ (DONDERO, 2016).

Contudo outros sistemas possuem maior dependência em relação ao suporte, por exemplo, a pintura, que perde seu valor de original ao mudar seu suporte. Todas as edições com a poesia de Schwitters não são questionadas a respeito de sua originalidade, pois "sua permanência e identidade são garantidas" (GREIMAS e COURTÉS, 2008) ${ }^{56}$. Entretanto seus quadros não podem migrar de suporte sem perder sua autenticidade, porque já seria outra obra a ser analisada, por exemplo, uma cópia. Esse sistema de dependência entre suporte e inscrição é denominado autográfico.

Assim, a manutenção da invariância da forma aplicada na investigação de imagens cria exclusões significativas para a apreensão do sentido. Como se os materiais não fossem pertinentes para a investigação do plano da expressão. Material container de Jeonghwa Seo (2013) é um exemplo de formas muito simples que ganham efeitos de sentidos diferentes de acordo com a mudança do suporte material. As diferenças não decorrem somente pela mudança de cor que cada material vai proporcionar aos bancos, mas também de brilho e textura.

A série The Material Container concentra-se na textura do artesanato local e de materiais de qualidades específicas. Eu selecionei materiais que têm uma tatibilidade especial e tentei encontrar materiais que combinassem entre si.

Criar um contraste entre dois materiais é uma boa maneira de equilibrar as qualidades de cada um deles. Eu também quis usar

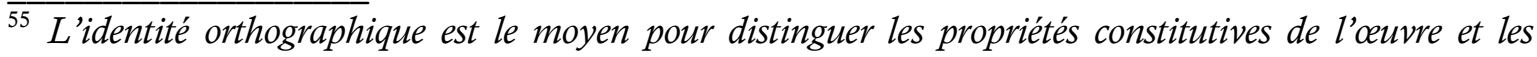
propriétés contingentes (c'est ce qu'on appelle les systèmes allographiques, qui possèdent un alphabet de signes disjoints et qui possèdent une notation).

${ }^{56}$ Não se discute uma abordagem editorial dos textos verbais, na qual o suporte ganharia relevância, porque esse viés nunca foi considerado pela semiótica clássica, porém seria mais um fator a ser integrado na problematização da invariância da forma.
} 
materiais que vemos ao nosso redor todos os dias, mas que não esperamos que sejam usados como mobília ${ }^{57}$ (SEO, 2013).

Embora não haja grandes variações de sentido, por conta do caráter utilitário que a forma do banco exige; notam-se diferenças de equilíbrio e de textura entre os objetos, que são pertinentes na apreensão do sentido - principalmente no momento da compra, cuja prática vai impor outras necessidades como o espaço no qual o banco vai ser inserido.

Figura 62 - Série Material container

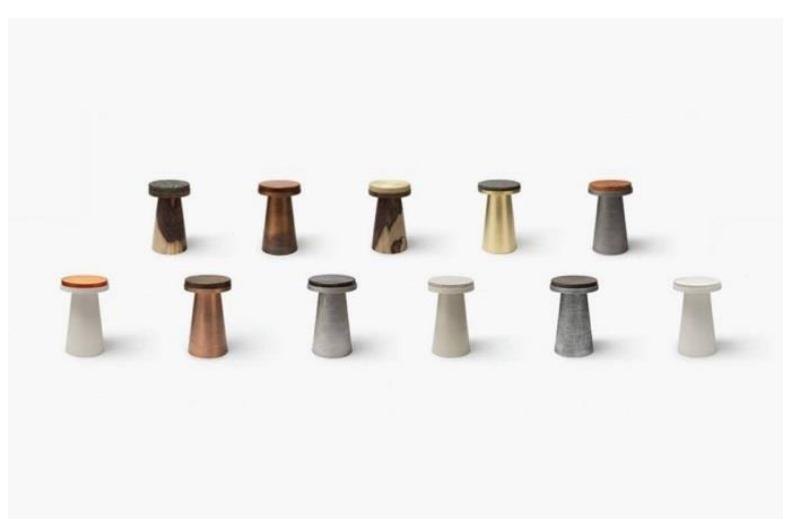

(SEO, 2013)

Esse tipo de dependência entre suporte e forma já não ocorre de modo tão marcante na literatura, objeto de estudo tão caro à tradição semiótica. Floch (2014) e Thürlemann (1979) foram pioneiros na investigação do plano da expressão e suas contribuições levaram ao desenvolvimento da semiótica visual, ao ponto de ser permitida uma ampliação dos modelos de análise, como acontece em toda ciência.

Após essa explicação sobre os limites impostos pela forma, Dondero (2016) busca em Fontanille (2008) um modelo mais adequado à integração dos objetos em sua circulação social e sua materialidade, pois:

Se na semiótica, até os anos 2000, o texto era considerado como o único conjunto significante e pertinente, porque homogêneo e hermético, os trabalhos de Fontanille sobre os objetos e as práticas

\footnotetext{
${ }^{57}$ The Material Container series is focused on the texture of local crafts and unique material qualities. I selected materials that have a special tactility, and tried to find out which combinations of materials go well together.

Creating a contrast between two materials is a good way to balance each material's qualities. I also wanted to use materials that we see around us every day, but don't expect to be used for furniture.
} 
permitiram considerar como um "conjunto significante" pertinente não só as textualidades herméticas, mas também uma dada situação $[\ldots]^{58}$ (DONDERO e REYES, 2016, p. 6).

Por isso, o percurso gerativo do plano da expressão foi tomado para tratar dessas questões.

Apesar de o modelo de Fontanille seguir para além do nível do texto, propiciando, por exemplo, uma abordagem da prática, Dondero e Reyes (2016) concentram-se no nível do objeto para afinar as relações entre suporte e texto, o que consequentemente influencia os outros níveis.

Dessa forma, os autores propõem uma mudança no percurso gerativo do plano da expressão, baseada no próprio Fontanille (2005), colocando em evidência a função do suporte na significação.

A ideia é pensar o suporte no nível do objeto dividido em duas faces: uma voltada para a substância e outra voltada para a forma. Isso significa adotar o suporte como o elemento constituinte principal desse nível, pois a função dupla entre forma e substância já era prevista pelo modelo.

A face da forma do suporte seria uma rede projetada sobre a face da substância para a constituição do nível do objeto. Por sua vez, essa instância formal torna-se substância no nível do texto, em que a rede de relações anteriormente projetada sobre a substância, nesse novo nível, estrutura a formação do texto. A face do suporte ligada à forma é chamada de suporte formal e a face do suporte voltada à substância é denominada suporte material.

Pode-se então afirmar que o nível do objeto é uma estrutura de acolhimento das inscrições composta de dois subníveis: o suporte formal e o suporte material. [...].

O suporte formal resulta de uma extração de propriedades que provêm do suporte material: o suporte material propõe linhas de força, tendências substanciais por meio das quais o suporte formal seleciona e opera uma triagem, ele oculta determinadas propriedades do suporte material e seleciona outras ${ }^{59}$ (DONDERO, 2016).

\footnotetext{
${ }^{58}$ Si en sémiotique, jusqu'aux années 2000, le texte était accepté comme le seul ensemble signifiant et pertinent, car homogène et clôturé, les travaux de Fontanille sur les objets et les pratiques ont permis de considérer comme un "ensemble signifiant " pertinent non seulement les textualités clôturées mais aussi une situation donnée [...].

${ }^{59}$ On peut donc affirmer que le niveau de l'objet est une structure d'accueil des inscriptions qui est composée de deux sous-niveaux, qui sont le support formel et le support matériel. [...].
} 
Retornando ao exemplo de Michelangelo, a percepção de formas encontradas na pedra bruta define o percurso da projeção dessa rede formal sobre a matéria e consequentemente, as possíveis formas textuais encontradas nessa ação. É possível compreender que o artista mostra como o suporte formal medeia a relação entre o suporte e aporte (texto), pois o que ele revela é sua interiorização do processo de realçamento dos níveis do objeto e texto-enunciado.

Essa citação de Michelangelo aponta também o caráter enunciativo do suporte formal, que depende das escolhas do enunciador diante do suporte material para constituir o texto. $\mathrm{O}$ "principio de pertinência que vai definir o suporte formal é o tipo enunciativo: ele incita, compele e modaliza um tipo de intercâmbio, uma estrutura de comunicação ideal e papéis da enunciação" (FONTANILLE, 2005, p. 4) ${ }^{60}$.

Portanto, o modelo de Fontanille teria uma adaptação no nível do objeto feita por Dondero (2016), que traz à luz a pertinência do suporte como mediador entre os níveis "abaixo" e "acima" da experiência da corporeidade. Logo, o percurso gerativo do plano da expressão possuiria uma adequação em sua configuração:

Tabela 8 - Suporte no percurso gerativo do plano da expressão

\begin{tabular}{|c|c|c|}
\hline TIPO DE EXPERIÊNCIA & $\begin{array}{l}\text { INSTÂNCIAS } \\
\text { FORMAIS }\end{array}$ & INTERFACES \\
\hline \multirow{2}{*}{ Prática } & \multirow{2}{*}{ Cenas da prática } & Processo de acomodação \\
\hline & & Cena predicativa \\
\hline \multirow[b]{2}{*}{ Corporeidade } & \multirow[b]{2}{*}{ Objetos } & Suporte Material \\
\hline & & Suporte formal de inscrição \\
\hline \multirow[t]{2}{*}{$\begin{array}{l}\text { Coerência e coesão } \\
\text { interpretativas }\end{array}$} & \multirow[t]{2}{*}{ Textos-enunciados } & $\begin{array}{l}\text { Suporte da inscrição } \\
\text { (Dispositivo de enunciação/inscrição) }\end{array}$ \\
\hline & & Isotopias figurativas da expressão \\
\hline \multirow{2}{*}{ Figuratividade } & \multirow[b]{2}{*}{ Signos } & Formantes recorrentes \\
\hline & & \\
\hline
\end{tabular}

(DONDERO, 2016)

Le support formel résulte d'une extraction de propriétés émanant du support matériel : le support matériel propose des lignes de force, des tendances substantielles parmi lesquelles le support formel sélectionne et opère un tri; il occulte certaines propriétés du support matériel et en sélectionne d'autres.

${ }^{60}[. .$.$] le principe de pertinence qui va définir le support formel est de type énonciatif: il engage, contraint$ et modalise en effet un type d'échange, une structure de communication idéale, et des rôles d'énonciation. 
Nota-se que a ideia de suporte formal como uma rede projetada pela instância da enunciação no suporte material não é estranha à tradição linguística e semiótica que definiram o conceito de forma tratado anteriormente. Hjelmslev considera a forma, tanto do conteúdo quanto da expressão, exatamente como uma projeção de formas sobre um sentido (substância).

É como os grãos de areia que provêm de uma mesma mão e que formam desenhos diferentes, ou ainda, como a nuvem no céu que, aos olhos de Hamlet, muda de forma de minuto a minuto. Assim como os mesmos grãos de areia podem formar desenhos dessemelhantes e a mesma nuvem pode assumir constantemente novas formas, do mesmo modo é o mesmo sentido que se forma ou se estrutura diferentemente em diferentes línguas. São apenas as funções da língua, a função semiótica e aquelas que dela decorrem, que determinam sua forma (HJELMSLEV, 2006, p. 57).

No entanto o autor dinamarquês, mesmo deixando um projeto a ser desenvolvido sobre as estruturas de significação que permeiam as culturas, preocupava-se em sua investigação com a langue.

Essa visão imanente do sistema linguístico, ao ser tratada no nível do objeto e da prática, não traria particularidades relativas ao seu próprio nível de pertinência? Um percurso de maior concretude das relações linguageiras, em comparação à abstração do sistema linguístico, talvez pudesse contar com maior elasticidade entre forma e substância, dependendo do nível considerado. O suporte, integrador de práticas e enunciados, catalizador de texturas no texto, realmente não teria espaço em uma tradição imanentista? Fontanille (2015) e Dondero (2016) mostram que sim e mesmo sob uma perspectiva estritamente hjelmsleviana, que consideraria essas abordagens "fora do texto"; a transcendência regida pela imanência não seria também imanente?

A linguagem, considerada num sentido mais amplo que aquele que lhe é atribuído pela linguística contemporânea, retomou sua posiçãochave no domínio do conhecimento. Em vez de impedir a transcendência, a imanência, pelo contrário, deu-lhe uma base sólida e mais nova. A imanência e a transcendência juntam-se numa unidade superior baseada na imanência (HJELMSLEV, 2006, p. 133). 
A digressão a respeito do primado da imanência que constitui e de certo modo prescreve as análises semióticas, concerne às nossas próprias preocupações sobre os limites dessa ciência da linguagem. No entanto acreditamos que as relações entre prática, suporte e texto nas inscrições urbanas possuem tal dependência nas estruturas de significação que não devemos ignorá-las.

Por meio dessa possibilidade de tratamento do suporte como mediador da prática e do texto, ganha-se uma ferramenta pertinente na análise das imagens e como a prática foi tema do segundo capítulo e o texto do capítulo três, o suporte seria o elemento que "juntaria as pontas". Verifica-se que ao longo da história das inscrições urbanas a mudança de suporte reflete uma alteração da prática e uma adequação plástica das obras.

Portanto, a constituição do suporte material e formal, que implica diretamente em escolhas do enunciador, bem como em triagens e misturas normativas, será observada na história das inscrições urbanas para compreender o desenvolvimento da prática ao longo do tempo em relação a suas mudanças nos suportes. Se a prática mudou e concomitantemente houve mudanças no aporte, de acordo com os capítulos anteriores, então, necessariamente deveria haver uma mudança no nível do objeto.

\subsection{MUdANÇAS DE SUPORTE NA HISTÓRIA DAS INSCRIÇÕES URBANAS.}

O percurso histórico das inscrições urbanas mostrou claramente que as vicissitudes dos grupos sociais ligados a determinadas modalidades de inscrições urbanas ajustaram continuadamente seus valores a normas sociais e a normas artísticas para manter ou alcançar o reconhecimento. Por isso, avalia-se cada modalidade para refletir sobre quais foram as mudanças na escolha do suporte, pois a prática exigia certo suporte material, que era ajustado à rede de possibilidades das formas consideradas pelo enunciador, que por sua vez direcionavam a formação do aporte.

Nas inscrições políticas, a prática exigia a maior visibilidade da inscrição para a comunicação com o público, pois o engajamento das pessoas exigia uma intensa repetição das inscrições e consequentemente, atingia-se um reconhecimento dos 
slogans políticos. Tamanho foi o reconhecimento dessas mensagens no Brasil que as inscrições poéticas muitas vezes parodiavam as inscrições políticas devido à sua consolidação na cultura. A inscrição "Abaixo a Ditadura", marco dos protestos contra o regime militar brasileiro, transformou-se em "Abaixo a vida dura" ou "Abaixo a dita dura". A paródia e a sátira partem de lugares comuns, de formas estabilizadas, para sua reelaboração.

Essa visibilidade voltada às pessoas em geral delimitava o uso do suporte material, bem como as coerções sociais do período: escrever tais inscrições contra o regime militar poderia trazer sérias consequências à vida do inscritor, caso ele fosse flagrado pela polícia. Por isso, muros em lugares públicos eram privilegiados pela prática, pois atingiam um grande número de pessoas, permitiam maior possibilidade para fugas e para a vigia. O spray era o instrumento mais eficiente devido ao seu fácil manuseio e à rapidez de execução. Essa imposição da prática restringia as escolhas enunciativas sobre o suporte material para a produção da inscrição. No plano da expressão visual, as letras bastão com pouca elaboração formal e o uso de frases curtas davam conta da necessária agilidade do ato e da comunicação direta com o público. Do mesmo modo que a elaboração poética em certas inscrições tanto em sua sonoridade verbal, quanto em seus conteúdos, reforçavam a comunicabilidade das inscrições.

A relação entre suporte material e suporte formal era delimitada pela prática, excessivamente arriscada, que também obrigava a escolhas de formas simples para o nível do texto-enunciado, que mesmo com poucos recursos, chegava a produções sofisticadas, por exemplo, na breve análise (capítulo 3) da inscrição política parisiense il est interdit d'interdire.

A prática da tag, semelhante a das inscrições políticas, tinha maior liberdade em relação ao suporte, já que sua comunicação se isentava da transmissão de conteúdos determinados. $\mathrm{O}$ reconhecimento buscado ligava-se estritamente à identificação do plano da expressão de uma assinatura. Por isso, a reprodução da tag não delimitava o suporte, pelo contrário, a quantidade excessiva da inscrição exigia a indeterminação do suporte. Somente pela quantidade chegava-se aos objetivos do grupo social.

Em relação às inscrições políticas, a tag é ainda mais condensada. Frases são reduzidas a um nome e o uso da letra bastão sem elaboração tipográfica é mantido, o 
que vai ser modificado ao longo dos anos para a letra cursiva, caracterizando um formato muito próximo de uma assinatura corrente. Tanto a tag tradicional, quanto a "moderna", possuem grande liberdade no uso do suporte, não restringindo o aporte como nas inscrições políticas. No entanto a rapidez da execução, devido à ilegalidade da prática e às metas de quantidade de reprodução, é um fator preponderante na escolha de formas simples.

Semelhantemente à tag, o throw-up mantém a mesma prática, porém, inicia-se uma maior exploração do suporte. Assim, seu uso passa a ser menos indiscriminado, porque a forma do aporte não se encaixa em todos os suportes. A elaboração tipográfica em duas cores, desenho das letras sobreposto a um fundo monocromático, e o tamanho da inscrição exigiam determinados suportes. Por exemplo, o throw-up não era feito dentro dos vagões de metrô, seu suporte material era a parte exterior, além de muros e outras superfícies; já a tag era feita dentro e fora do metrô, assim como em qualquer lugar.

A formação do throw-up revelava uma insatisfação da prática em relação a sua capacidade de atingir o reconhecimento. Muito embora a continuação da prática quantitativa anterior limitasse a exploração do suporte material. O throw-up seria uma prática que intermediaria tag e o grafite, pois as coerções da prática quantitativa foram mantidas, mas uma abertura para as possibilidades do suporte começava a ser delineada. O que efetivamente aconteceu no grafite, pois a reprodução da inscrição foi eliminada e o suporte foi delimitado. Com isso, iniciou-se uma exploração das possibilidades do suporte material, em que as escolhas enunciativas centravam-se no suporte sem sofrer grandes coerções da prática. O suporte formal ampliaria, então, o repertório de formas do aporte, levando o grafite não mais a uma competição quantitativa, mas a uma competição sobre a qualidade.

$\mathrm{O}$ fator reprodutibilidade adequava-se à mobilidade do suporte. Quanto mais elaborado fosse o aporte, maior o impacto causado no público e maior o reconhecimento, já que o suporte mais utilizado era a parte exterior dos vagões de metrô, que percorriam toda a cidade divulgando a obra. Contudo a prática ainda restringia o uso do suporte e por consequência isso afetava o aporte, porque o grafite no metrô era ilegal. Elaborar um grafite demandava um risco muito alto, já que entrar escondido nas garagens de metrô à noite tinha inúmeros perigos: trens que se moviam 
subitamente, exposição à corrente elétrica, cães de guarda e vigilância noturna. Depois de passar por tudo isso, o grafiteiro fazia sua inscrição durante a noite, na escuridão.

O aumento da fiscalização nas garagens de metrô e a inserção do grafite no mercado de arte levaram a uma mudança de suporte: o muro e a tela. Devido a essa incorporação, as coerções da prática diminuíram e a exploração do suporte formal aumentou. As condições de produção da obra tornaram-se mais "confortáveis" para o inscritor e isso é refletido na qualidade do aporte.

Por exemplo, na comparação entre o grafite de Crash realizado no metrô e em tela, verifica-se um melhor acabamento formal do segundo, contudo, esse é somente o início da exploração do suporte material, pois o exemplo a seguir mostra a fase em que os artistas apenas transportavam a obra do metrô para a tela.

Figura 63 - Comparação entre suportes na obra de Crash

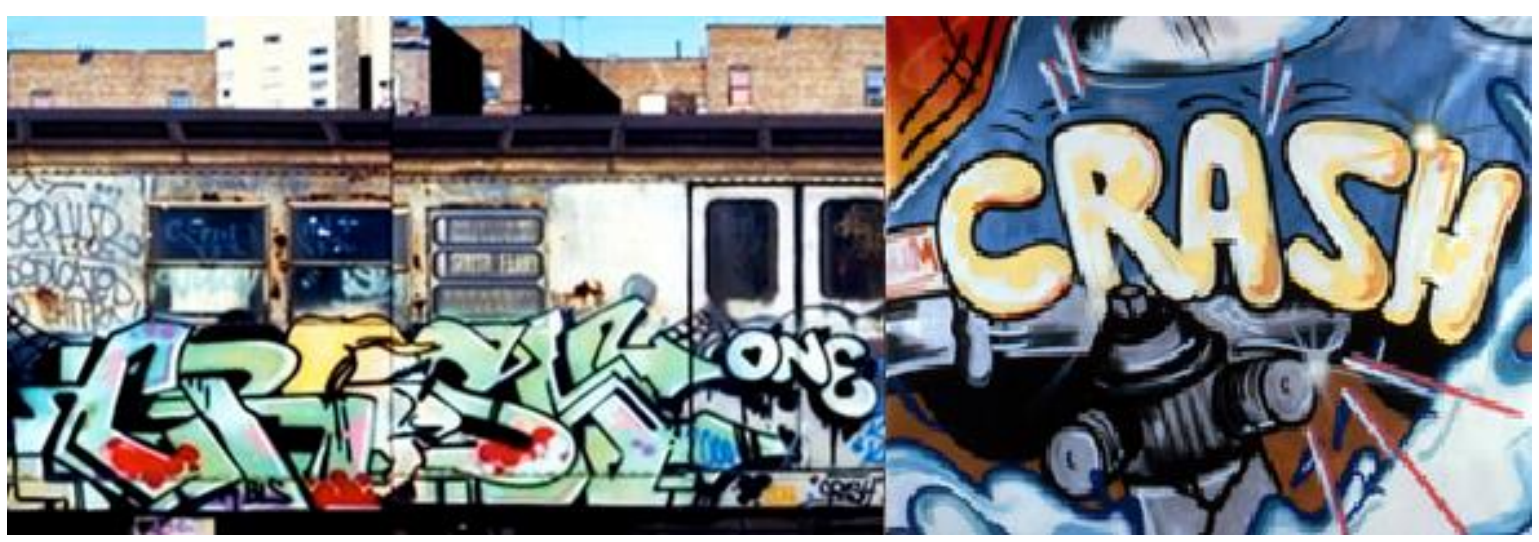

(CRASH, 2014)

Nessa evolução de formas, surge a arte urbana, cuja prática incide na valorização do suporte e do aporte. Muitos artistas do grafite perderam-se nessa mudança, pois a simples transposição de formas de um suporte a outro, no caso do muro ou do trem para a tela, não satisfazia às exigências de originalidade das normas artísticas. Por outro lado, artistas que iniciaram no grafite aceitaram tão bem os desafios do suporte formal dessa nova modalidade, que são difíceis de categorizar na história da arte, porque levaram a arte urbana para o campo da arte contemporânea. Esse é o caso de Basquiat e Rammelzee. 
Figura 64 - Grafite de Samo (Jean-Michel Basquiat)

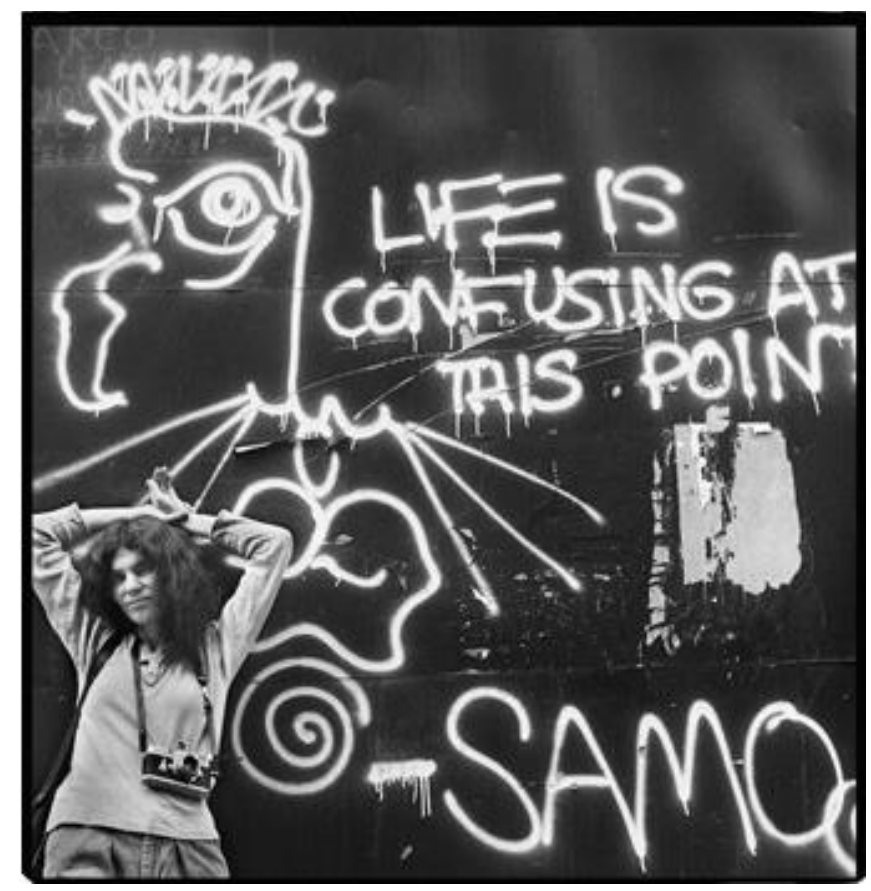

(SUBSOLO ART, 2012)

Figura 65 - Tela de Basquiat

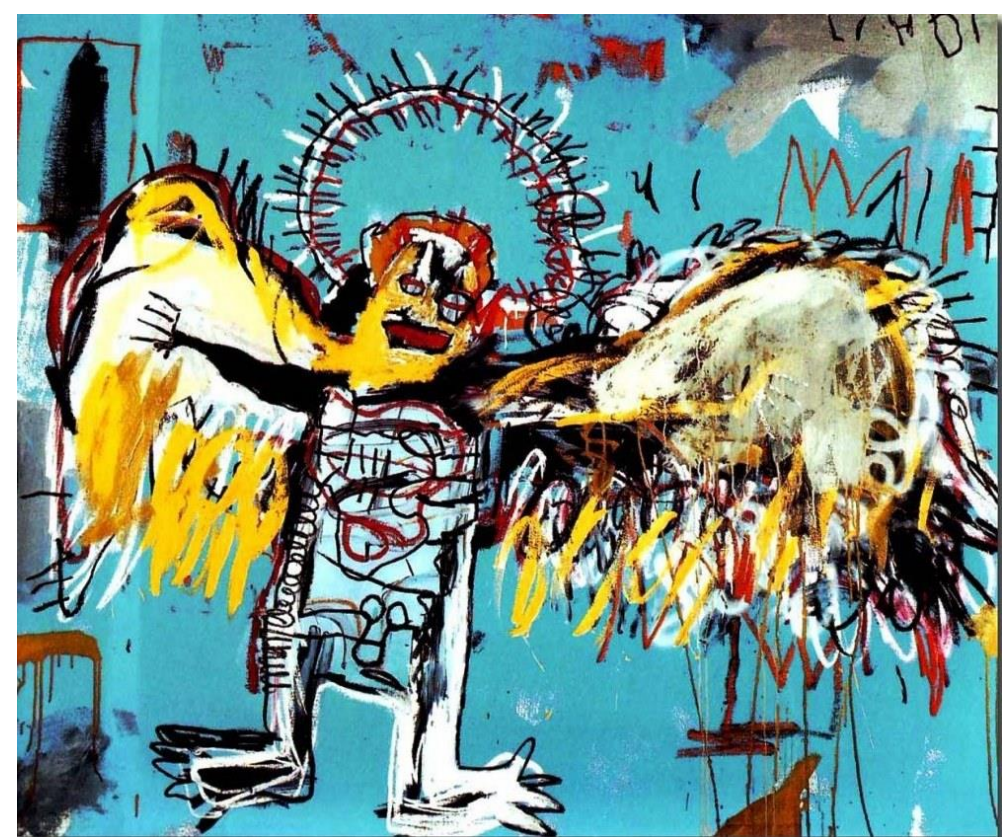

(EMMERLING, 2003, p. 6)

No exemplo acima, observa-se, na comparação entre um grafite e uma tela de Jean-Michel Basquiat, a elaboração de cores e formas na tela e a exploração da materialidade da tinta, fatores tão caros à arte contemporânea estadunidense como 
pode ser visto nas obras de Robert Raucshenberg, de Willian de Kooning e de Jackson Pollock, que não correspondem ao grafite de SAMO, pseudônimo de Basquiat no grafite. Enquanto o grafite de Basquiat é composto de desenhos simples ao lado de frases poéticas com certo apelo ao enunciatário, à moda das inscrições políticas parisienses; suas obras de arte urbana centram-se na plasticidade e no gesto do pintor. Seus grafites seguem as normas endógenas da modalidade e suas telas inovam normas.

$\mathrm{Na}$ pichação, o princípio do throw-up é desenvolvido pela segmentação dos suportes materiais e pela elaboração tipográfica. A prática de reprodução massiva é preservada, porém a qualidade do espaço e do suporte material ganha maior pertinência na pichação. A visibilidade da inscrição rege sua quantificação, pois não basta espalhar o picho pela cidade, o lugar de sua inscrição é igualmente importante. Além disso, uma divisão de suportes é encontrada na modalidade, já que há pichadores "especializados" em portas, em janelas ou em lugares altos ("picos"), ou seja, determinado picho é inscrito somente ao redor desses elementos arquitetônicos (portas, janelas etc.).

Ao invés de uma reprodução puramente excessiva (tag), a pichação adequa a prática ao suporte, assim como o throw-up, porque a disputada competição de formas iguais não rendia ao inscritor o reconhecimento almejado. No entanto a pichação vai além, pois ela explora o suporte material e o espaço em que ele se insere para conseguir a maior visibilidade possível e consequentemente o reconhecimento. Essa relevância dada ao suporte material repercute através do suporte formal na própria inscrição: uma sofisticada tipografia é produzida para associar-se à visibilidade do suporte $^{61}$.

Já a pichação-arte, passa pelo mesmo processo da arte-urbana. Nota-se uma rígida transposição de aporte em diferentes suportes, quer dizer, a pichação vai do muro para a tela sem considerar as potencialidades que o novo suporte pode trazer. Como essa modalidade ainda está em formação, segundo nosso ponto de vista, provavelmente haverá uma reformulação das escolhas enunciativas em relação ao suporte formal da pichação-arte que alterarão o aporte. Essa tendência já é delineada

\footnotetext{
${ }^{61}$ Uma das estórias a respeito da origem da tipografia da pichação diz que as formas angulares e verticalizadas das letras emulam a verticalidade arquitetônica do centro da cidade de São Paulo. Essa é uma especulação que condiz muito bem com a proposta de adequação entre suporte e aporte.
} 
na obra do pichador Cripta, cujas exposições em galerias já mostram uma mudança de formas da pichação em tela.

Figura 66 - Pichação de Cripta

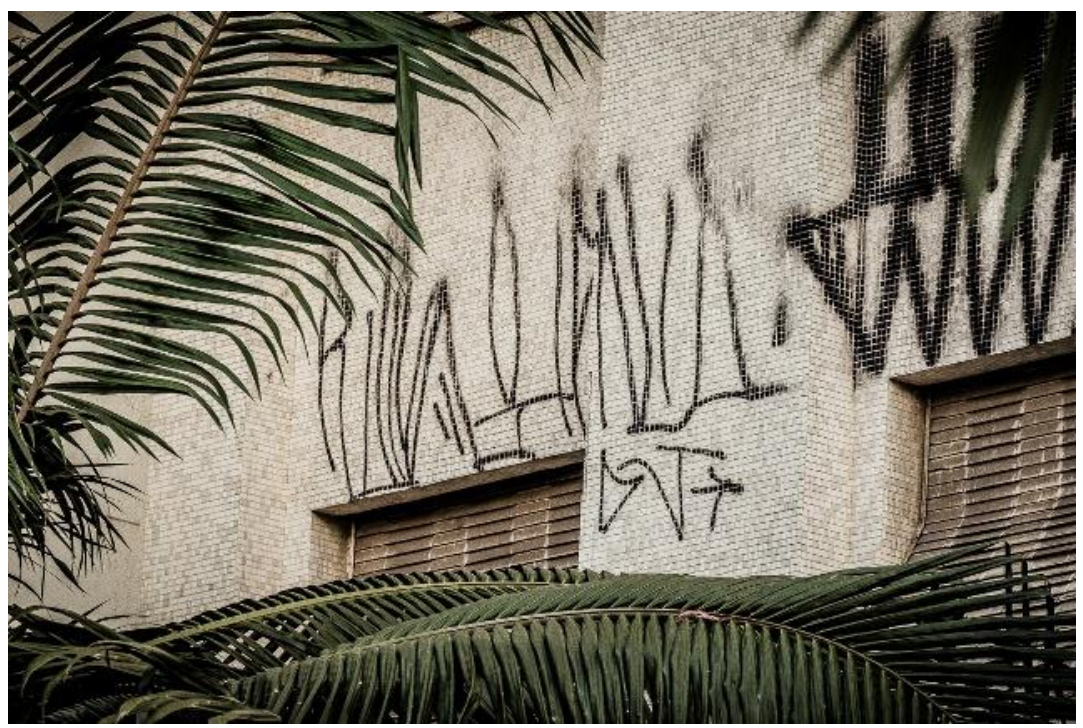

(ASSIS, 2016)

Figura 67 - Pichação-arte de Cripta em galeria nova-iorquina

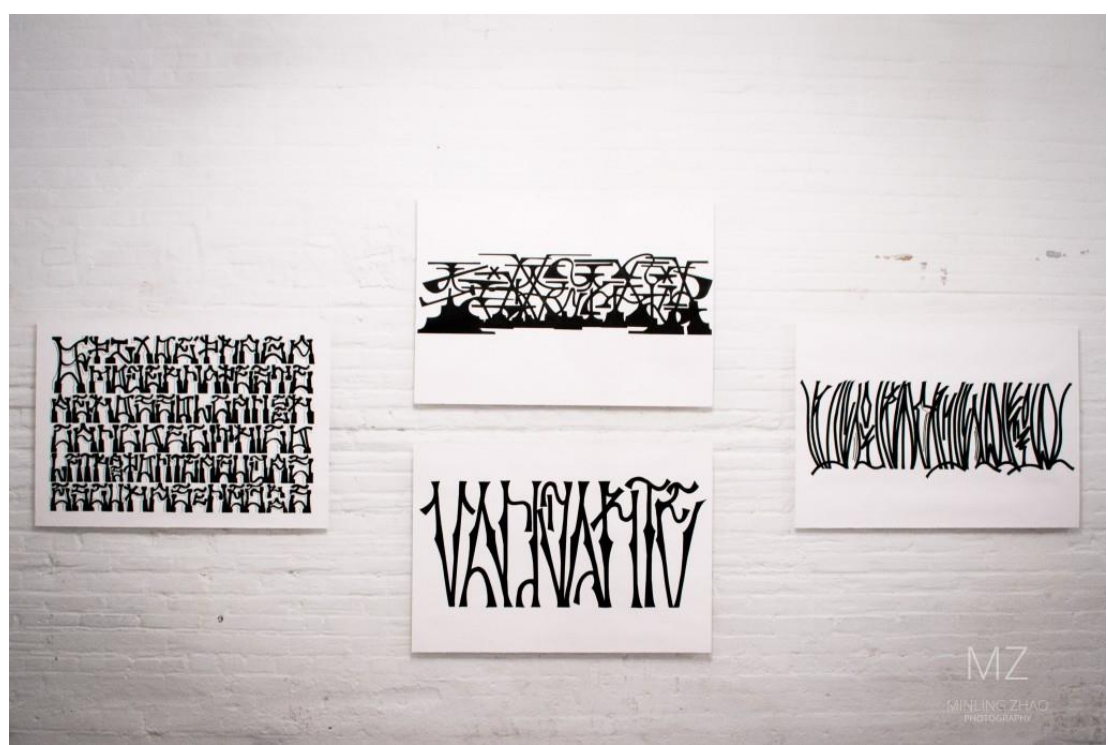

(ZHAO, 2016)

A comparação entre os dois tipos de trabalho aponta para a definição da pichação-arte como uma nova modalidade de inscrição urbana, porque as coerções das normas endógenas são reelaboradas para explorar o suporte formal da tela. 
Contudo essa é uma tendência encontrada em apenas um artista e só o tempo poderá confirmar a hipótese apresentada.

Por fim, o grapicho é uma modalidade que deriva, sobretudo, do grafite em relação à prática e ao suporte, já o aporte é resultado de uma mistura com a pichação. Embora haja maior desenvolvimento do suporte formal, o grapicho está para o picho, assim como o throw-up está para a tag, pois ambos partem de uma prática anterior motivada pela lei da quantidade, para seguir em direção à qualidade da inscrição e à seleção do suporte. Embora o grapicho seja realizado quase exclusivamente por pichadores, a prática faz com que o inscritor detenha-se mais tempo sobre o suporte muro.

Desse modo, o suporte formal vai permitir um maior desenvolvimento cromático e eidético das inscrições, mas com a manutenção do desenho tipográfico da pichação. A proliferação de uma mesma marca cede lugar à criação de inscrições singulares, ou seja, a inscrição é feita única e exclusivamente para aquele suporte: não se encontra geralmente dois grapichos iguais em suportes diferentes. Observa-se, então, uma absorção da prática do grafite pela pichação, cuja triagem e exploração do suporte material trazem maior elaboração ao aporte.

Ao tratar de cada modalidade individualmente, nota-se que a escolha do suporte, ajustada à prática, interfere diretamente na qualidade do aporte. As transformações entre as modalidades devem-se em boa medida às coerções da prática que ao exigirem determinado suporte material, possibilitam um maior ou menor desenvolvimento do suporte formal, repercutindo no aporte. Verifica-se também que ao longo da história das inscrições urbanas a prática passa a dar mais relevância ao suporte formal, ou seja, as escolhas enunciativas projetam redes de relações plásticas mais elaboradas sobre o suporte e o utilizam mais e mais em seus aspectos materiais, chegando a modalidades com maior originalidade visual.

A seleção do suporte material, seguidora das exigências da prática, pode ser vista por meio de uma perspectiva quantitativa ou qualitativa, cuja influência no aporte de cada modalidade é crucial. Percebe-se então que há uma lógica nessa dinâmica de utilização do tipo de suporte a ser investigada. 


\subsection{BASES IMPLICATIVAS E CONCESSIVAS}

A diferença de suporte encontrada nas modalidades de inscrição urbana poderia ser considerada pelo viés da tensividade, na medida em que uma lógica implicativa ou concessiva regeria a escolha de suporte.

Como já visto no item 3.2 desta tese, a implicação, operada pela lógica se... então, poderia ser caracterizada pela mesma direção entre extensidade e intensidade. No campo tensivo, se uma valência intensiva aumenta, então uma valência extensiva a acompanha. Nota-se um regime converso na relação entre os termos. O modo de eficiência que vai caracterizar a implicação é o pervir, a espera. O progresso lento (andamento e temporalidade) que privilegia a quantidade (número) forma "uma das duas maneiras pelas quais uma grandeza tem acesso ao campo de presença e pode aí se estabelecer" (ZILBERBERG, 2011b, p. 271).

Este último [o pervir] - na ausência de qualquer contraprograma inoportuno de sobrevir - valida a confiança do sujeito em sua própria capacidade e nos recursos de que dispõe. O sucesso do pervir tranquiliza o sujeito pela convicção de que o mundo é justamente o "seu" mundo, onde têm lugar o cálculo e a previsão [...] (ZILBERBERG, 2011b, p. 243).

Já a concessão, trabalha em termos contrários à implicação. Operada pela lógica do embora..., a concessão produz um regime inverso entre intensidade e extensidade, pois ela "põe o 'acento de sentido' numa figura gramatical modesta, apenas uma figura entre as demais, mas que se encontra aqui - circularmente destacada e promovida ao nível de chave do sentido, parcial ou total conforme o caso" (ZILBERBERG, 2011b, p. 242-243). O modo de eficiência da concessão é o sobrevir, que, marcado pela saturação do andamento e da tonicidade, rege o acontecimento, cuja força de presença traz o sujeito para "fora da ordem":

Um objeto-acontecimento ingressa no campo de presença e aí se mantém como fato singular, estranho. Seus traços negativos assimétricos, intransitivos e sobretudo inconexos - questionam a relatividade da extensidade, que prevê um pacto entre o "tudo se inter-relaciona", demasiadamente vago, e a unicidade demasiadamente marcada (ZILBERBERG, 2011b, p. 279). 
Devido ao caráter de exceção produzido pela concessão, "a implicação tem a primazia na linguagem e a concessão se exerce à custa da implicação [...]" (ZILBERBERG, 2011b, p. 245). A previsibilidade formada pela implicação é mudada pela concessão do acontecimento, imprevisível.

Partindo das propostas de Wölfflin (2006) sobre o barroco e o clássico nas artes, Zilberberg (2008) aplica os conceitos de implicação e concessão em cada estilo de pintura, revelando uma estrutura lógica que rege sua produção. Assim, toma-se o tema da história bíblica sobre Suzana, recorrente na história da pintura, para mostrar como a concessão e a implicação regem o aporte e consequentemente, como vão definir cada estilo.

Tratada no capítulo 13 no livro de Daniel (BÍBLIA), a história conta sobre a ameaça que Suzana sofreu de dois juízes anciãos. Suzana, bela esposa de um homem rico chamado Joaquim, era cobiçada por dois anciãos que frequentavam sua casa. Por conta dessa paixão, certo dia os velhos juízes espiavam o banho de Suzana em um jardim de sua casa e aproveitando o ensejo de que a bela mulher havia dispensado suas acompanhantes para que pudesse aproveitar seu banho a portas fechadas, os velhos a abordaram para que Suzana se entregasse a eles e a seus desejos. Caso Suzana recusasse, seria denunciada por adultério.

Recusando-se ao coito, Suzana foi denunciada pelos velhos, que inventaram uma acusação na qual a bela jovem tinha sido surpreendida por eles em um ato libidinoso, porém, eles não haviam conseguido prender o jovem amante, pois ele era forte e por isso conseguiu escapar das mãos dos anciãos. Prontamente sentenciada, Suzana foi abatida pelo prestígio dos anciãos, contudo, no momento de sua sentença, Deus agiu sobre Daniel para que ele interviesse no julgamento para desacreditar a versão dos velhos juízes. Assim feito, Daniel propôs que os depoimentos de cada acusador fossem ouvidos separadamente e pela divergência de cada versão, comprovou-se a mentira e os anciões foram mortos.

Tal história é tema tanto na pintura clássica, quando na pintura barroca. $\mathrm{O}$ exemplo de Wölfflin (2016) aborda um quadro de Rembrandt sobre o tema do banho de Suzana e a partir desse exemplo, emprega-se um quadro de Lotto para contrapor-se ao estilo barroco.

Segundo Zilberberg (2008), o estilo barroco é concessivo, porque exige um contraste entre os elementos plásticos constituintes do quadro, que são dispostos de 
modo inverso para criar autonomia entre eles: "a arte barroca emancipa a cor, pois a trata de modo autônomo e faz com que determinada cor sobressalente crie por si só um acontecimento cromático suficiente" (ZILBERBERG, 2008, p. 13-14) ${ }^{62}$. O quadro de Rembrandt, Suzana no Banho, demonstra essa força do contraste cromático tão cara ao barroco, em que o vermelho da roupa de Suzana sobrevem à massa uniforme do cenário do jardim.

Figura 68 - Suzana no banho (1647)

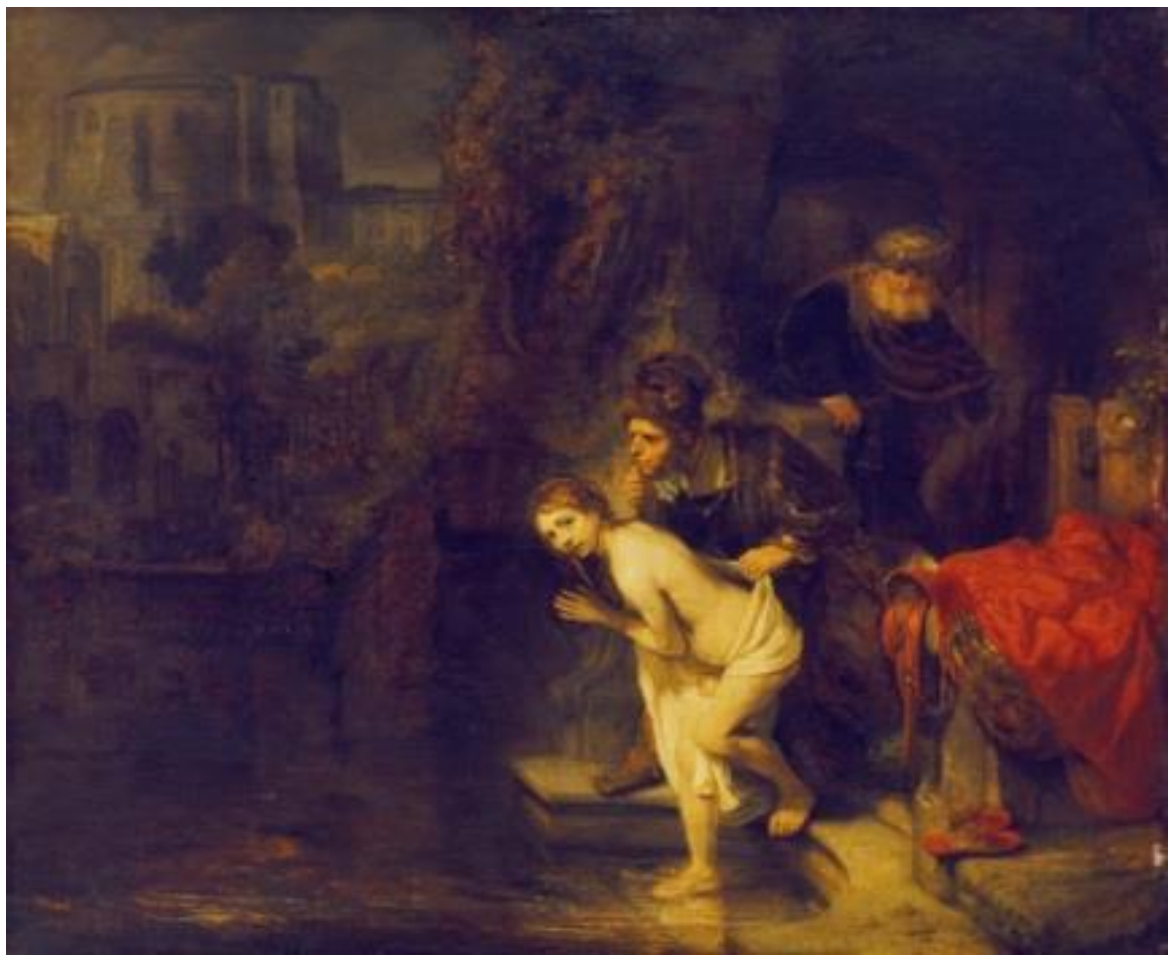

(MUSÉE HISTORIQUE ENVIRONNEMENT URBAIN, 2009)

O manto de Suzana e o restante do quadro estariam em uma relação concessiva. Imaginemos que o brilho do vermelho fosse intensificado por um programa de edição de imagens que respeitasse suas relações internas. E então, necessariamente o restante do quadro ficaria mais escuro, já que essa composição segue uma lógica de relação inversa. Embora a maior parte do quadro se mantenha em um determinado espectro de cores, o que levaria a uma previsibilidade cromática nos percursos do olhar sobre a pintura, surge um vermelho cintilante que rompe com essa expectativa, trazendo à percepção um ponto intenso, concentrado e inesperado.

\footnotetext{
${ }^{62}[. .$.$] l'art baroque «émancipe la couleun, la traite pour elle-même et fait en sorte que certaine couleur$ survenant crée un événement chromatique suffisant [...].
} 
[Na Suzana no Banho, de Rembrandt] Ainda que neste último as vestes atiradas pela banhista ao chão, de um vermelho brilhante, intensificado pela coloração marfim do corpo, projetem a sua luminosidade para fora do quadro, ninguém duvidará do significado objetivo dessa mancha de cor, e dificilmente esquecerá que esse vermelho é um vestido, o vestido de Suzana; apesar disso, o espectador sente que está muito distante de todos os quadros do séc. XVI. [...] o vermelho incandescente parece escorrer em gotas ao longo dos cordões pendentes e juntar-se novamente embaixo, nos chinelos, como numa poça de fogo; decisiva para o efeito, contudo, é a peculiaridade dessa coloração totalmente ordenada sobre um dos lados [que] o quadro adquire, assim, uma ênfase que nada tem a ver com as exigências da situação (WÖLFFLIN, 2006, p. 281).

Por outro lado, o estilo clássico exige um tratamento homogêneo dos elementos picturais, pois a luz está a serviço da revelação da forma. Evita-se a impressão subjetivista da sombra (segundo as normas clássicas), porque a beleza encontra-se na clareza da pintura. Em termos tensivos, "a arte clássica tem uma prática implicativa fundada sobre a retomada da mesma cor com ligeiras variações em diferentes lugares na tela" (ZILBERBERG, 2008, p. 13) ${ }^{63}$. As categorias cromáticas e eidéticas do texto clássico são conduzidas a uma mesma direção, cuja disposição no espaço da tela é uniformemente equilibrada.

No séc. XVI, o desenho encontra-se totalmente a serviço da clareza. Não é imprescindível que todas as perspectivas sejam explícitas, mas percebe-se que em cada forma está presente o impulso de autorrevelar-se (WÖLFFLIN, 2006, p. 272).

Retomando o exemplo de nosso programa de edição de imagens, ao aumentar a intensidade de brilho em qualquer elemento do quadro, todo o conjunto seguiria essa alteração, assim, o quadro como um todo ficaria mais brilhante, porque haveria uma relação conversa entre os elementos constituintes da pintura. O lema dos três mosqueteiros (e da Suíça) "um por todos e todos por um" aplica-se adequadamente à estrutura pictural da arte renascentista.

$\mathrm{Na}$ arte clássica, a luz e a sombra são tão importantes quanto o desenho (em sentido estrito) para a definição da forma. Cada luz tem a função de caracterizar a forma, em seus detalhes, e de articular e ordenar o conjunto (WÖLFFLIN, 2006, p. 274).

\footnotetext{
${ }^{63}$ L'art classique a une pratique implicative fondée sur le rappel de la même couleur en différents endroits avec de légères variations $[\ldots]$.
} 
O mesmo tema de Suzana no banho, composto no estilo clássico, mostra essa implicação entre formas e cores, pois não há contrastes intensos e nem formas sobressalentes no quadro. A pintura de Lorenzo Lotto Susanna e $i$ vecchioni é um exemplo pertinente do estilo clássico na pintura.

Figura 69 - Suzana e os velhos (1517)

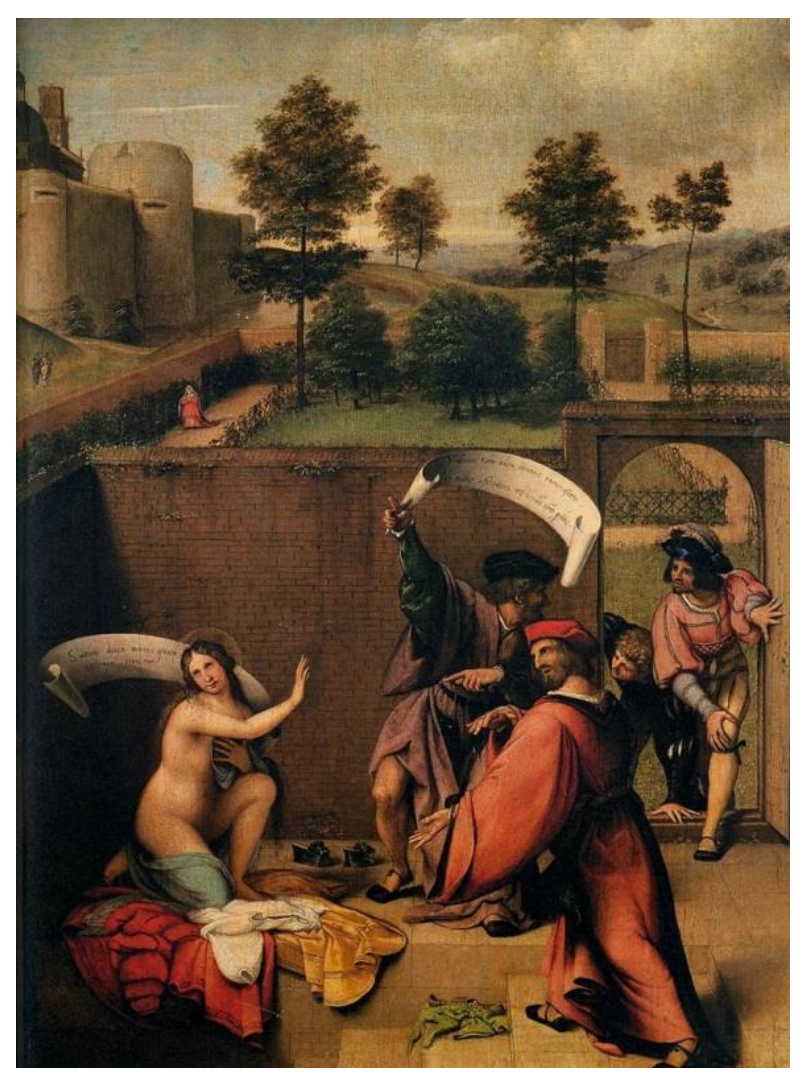

(ARTRIBUNE, 2012)

A pele nua de Suzana tem a mesma tonalidade que a pele de seus detratores, a cor e o pregueado de sua roupa não difere das vestes dos homens em primeiro plano, nem do vestido da mulher que caminha no plano de fundo. O espaço entre as figuras do quadro produz um efeito de leveza, enquanto em Rembrandt há maior compactação entre as figuras e os tons escuros indefinem os contornos, criando maior densidade na pintura.

Portanto, a arte clássica tende a uma lógica implicativa de composição e a arte barroca a uma lógica concessiva, cujos estilos linear e pictórico são fundamentais para a consolidação da natureza de cada estilo. Zilberberg (2012), então, dispõe essa relação entre concessão e implicação no campo tensivo, em que esta é colocada no 
extremo crescente da extensidade e aquela é situada no extremo decrescente do eixo extensivo. A alta intensidade da concessão caracteriza o acontecimento e a baixa intensidade da implicação está ligada à regra ou ao exercício.

No entanto seria possível pensar na concessão com baixa intensidade e na implicação com alta intensidade. Primeiro, porque a estrutura lógica do campo tensivo o prevê, segundo, porque a própria concessão faz parte do sistema de significação, ou seja, já é regra.

O exemplo linguístico da concessão "embora estivesse com uma forte febre, ele saiu", cujo "embora põe em xeque o esperado porque: 'ele não saiu, porque estava com uma forte febre"” (ZILBERBERG, 2011b, p. 243); não seria caracterizado um acontecimento, porque já faz parte da norma linguística. Se cada frase na língua elaborada por meio da concessão fosse um acontecimento, não haveria tanta recorrência desse uso. Assim, há na língua uma lógica concessiva átona, pois ela integra o uso. Apesar de sobrevir a uma rotina, essa concessão seria tão cristalizada na fala que as expectativas de um determinado desenvolvimento da frase, quando surpreendidas, não gerariam um aumento de intensidade.

Os estudos tensivos, em certa medida, ocupam-se mais detidamente do acontecimento, formado em uma relação inversa. Isso pode ser visto, por exemplo, nos verbetes pervir, sobrevir, implicação, concessão e acontecimento do glossário tensivo, em que os termos relacionados ao acontecimento são mais desenvolvidos. Além disso, devido à ausência do termo implicativo, o par rotina (regra ou exercício) e acontecimento está desfalcado em tal glossário, como ocorre em pervir e sobrevir. Porém a concessão átona e a implicação tônica, formadas em uma relação conversa, também fazem parte da estrutura de significação.

Essa discussão é proposta devido ao uso do suporte nas inscrições urbanas, que emprega uma lógica implicativa para alcançar o valor reconhecimento por meio do impacto gerado pela quantidade excessiva de reprodução, bem como as inovações são produzidas por conta de uma adoção de uma lógica concessiva. 


\subsection{LÓGICA IMPLICATIVA E CONCESSIVA NA ESCOLHA DE SUPORTE}

De acordo com a proposta sobre a história das inscrições urbanas, a tag, o throw-up, as inscrições políticas e a pichação possuem uma prática semelhante, apesar de os textos possuírem características próprias tornando-os modalidades distintas. $\mathrm{O}$ mesmo ocorre com o grafite, a arte urbana, o grapicho e a pichação-arte. Como foi visto também, o uso do suporte intermedeia a prática e o texto e por isso contribui para a formação de cada modalidade. Seguindo essa reflexão, observa-se o emprego da concessão e da implicação nas estratégias formadoras das práticas de cada tipo de inscrição urbana. O primeiro grupo seria desenvolvido sob uma lógica implicativa e o segundo grupo sobreviria a essa lógica implicativa por meio da concessão.

As inscrições políticas, a tag e o throw-up originaram as inscrições urbanas na segunda metade do século XX e por isso, são referência para toda a história das inscrições urbanas. Mesmo com a evolução das normas endógenas, baseadas em misturas e triagens com normas artísticas, sociais e com outras normas endogeradas, a influência das práticas pioneiras vão transpassar todas as modalidades na história por meio da prática transgressora, do uso do espaço público, da busca do valor reconhecimento e da reprodutibilidade da inscrição.

A quantidade de inscrições engloba todas essas premissas, porque se há grande quantidade de uma inscrição espalhada pela cidade, então, ela foi inscrita sem autorização em espaços públicos e privados, pôde ser facilmente reconhecida e foi reproduzida em larda escala. Essa lógica do "se o número de inscrições é alto, então, alcanço reconhecimento" vai fundar a origem das inscrições urbanas pelo emprego indiscriminado do suporte e todas as suas consequências.

É pelo pervir que as inscrições gradativamente chegarão ao impacto desejado, ou seja, a lógica implicativa conduz a escolha do suporte, que por sua vez define o texto. O "quanto mais, melhor" levará aos impasses dessa quantificação exacerbada. Essa lógica fundadora vai ser redefinida no segundo grupo (grafite, arte urbana, grapicho e pichação-arte).

A massificação da inscrição conduzida pela prática pioneira das inscrições urbanas é redefinida no grafite, mas baseada na implicação. O "embora o número de inscrições seja baixo, ainda alcança-se o reconhecimento" mostra que a concessão 
pode desenvolver a prática. Mesmo com a lógica quantitativa rompida, as premissas da transgressão, do espaço, do reconhecimento e da reprodutibilidade foram mantidas tanto pelo uso do suporte vagão de trem, quanto pelo uso do muro. Enquanto os demais fatores foram preservados na mudança de modalidade, $o$ fator reprodutibilidade foi adequado a uma perspectiva dinâmica: a circulação do suporte ou o espaço de grande circulação de pessoas, em que o suporte se situe substitui a reprodução massiva do texto.

Essa estratégia concessiva no emprego do suporte vale também para o grapicho, mas não para a arte urbana e para pichação-arte, que levaram às últimas consequências a concessão inicial do grafite, formada na lógica implicativa do grupo da tag. O "embora o número de inscrições seja um, ainda alcança-se o reconhecimento" perturba os fatores constituintes das inscrições urbanas, pois a transgressão é perdida com a utilização de muros autorizados e de tela como suporte, e o espaço público da obra é trancado em galerias e museus.

No entanto, ao longo do tempo, a arte urbana feita em muros conseguiu realocar o fator transgressão para o nível do texto e não mais para o nível do objeto. A qualidade do texto é transgressora, embora o suporte seja autorizado, porém, isso somente ocorre na arte urbana descendente do grafite, cujo suporte é o muro e por isso, são preservados os outros fatores. Atualmente, só os inscritores mais tradicionais não admitem o uso do suporte autorizado. No mais, as inscrições grafite ou arte urbana, mesmo com essa ausência da ilegalidade na apropriação do suporte, são reconhecidas.

Já o suporte tela ainda sofre muita resistência em relação às normas endógenas da prática, porque elimina fatores decisivos da indentidade das inscrições urbanas e não os remodela. A absorção das normas artísticas e, sobretudo, a inserção dessas inscrições no mercado de arte visa ao valor reconhecimento que, enquanto inscrição urbana, causa polêmica. Contudo a escolha desta pesquisa é pautada no valor reconhecimento como elemento estruturador da prática das inscrições urbanas.

Desse modo, tanto a pichação-arte, quanto a arte urbana feita em tela são consideradas inscrição urbana, porque não existem pintores em tela de inscrição urbana, mas inscritores que usam a tela como mais um suporte para alcançar o valor reconhecimento. Por meio dessa prática que o suporte traz consigo, chega-se à transgressão de normas sociais (de classes) e o espaço do museu e de galerias conduz à 
cobertura midiática, levando a inscrição para outro patamar da dinâmica de espaço público e de reprodutibilidade.

A história das inscrições urbanas mostraria então uma passagem de estratégias implicativas na escolha do suporte, encontradas em sua origem, para uma estratégia concessiva, acompanhando as triagens e misturas normativas no nível da prática. Entretanto alguns artistas contemporâneos como Banksy, Invader, Kobra e OSGEMEOS alcançaram tal nível de reconhecimento, que suas obras poderiam ser definidas pela junção das duas estratégias. Trata-se da implicação, reconhecida na tag, na pichação, etc., e da concessão, ligada ao grafite, à arte urbana, etc., juntas para formar uma massificação de obras únicas.

Muito próxima à estética de Andy Warhol, cujas obras em série apontam para uma reprodutibilidade sem perder a aura, as inscrições contemporâneas alcançam um número alto de produção, muito próximo ao das tags, mas sem seguir uma estética serial. Por exemplo, na década de 1970, IN comemorou seu throw-up número cinco mil pintando um vagão inteiro à moda do grafite, o que lhe conferiu o título de king ou rei na linha. Após sua inscrição número dez mil, IN "aposentou-se" (CASTLEMAN, 2012, p. 92-93). Nos dias de hoje, Invader (que não está aposentado) chega ao número de 3323 obras espalhadas em 65 cidades ao redor do mundo, sem contar com exposições e fotos na internet, que ampliam essa quantidade (INVADER, 2014). Ainda que IN tenha chegado à marca dez mil, Invander e todos os outros artistas contemporâneos não reproduzem um mesmo texto, cada obra é única.

Assim, a produção massiva de obras únicas leva a uma implicação da concessão, se é possível chamar a estratégia desse modo paradoxal, porque ao atingir a fama, os inscritores produzem impacto no enunciatário a cada obra. Basta acompanhar a temporada chamada de Better out than in que Banksy passou em Nova Iorque em 2013 para ver a comoção causada pelo seu projeto de fazer uma obra por dia nessa cidade durante um mês (NYC-ARTS, 2015). Mesmo com a previsibilidade da recorrência da produção, cada obra gerava um frisson no público - a espera do inesperado pautava essa relação entre artista e público (GREIMAS, 2002).

De maneira semelhante, o documentário Exit Through the Gift Shop (2010) mostra a criação "artificial" de um artista de arte urbana, que se apropria dessa lógica implicativo-concessiva para conseguir êxito. Ironicamente, a história de Mister Brainwash revela um desvio do esquema tradicional de possuir uma carreira na arte 
urbana que trouxesse reconhecimento, para depois chegar a esse estado de produção de obras-primas. Ao invés disso, o artista cria um curto-circuito por meio do marketing, que vai lhe conferir reconhecimento, e a partir de então sua produção massiva causa impacto. Com uma crítica ao modelo de mercado de arte e ao consumismo, o documentário de Banksy propõe uma reflexão sobre o consumo de arte, pois não é por acaso que na saída de cada museu há sempre uma loja de presentes.

Portanto, o desenvolvimento da história das inscrições urbanas conduziu a uma junção das duas estratégias de utilização do suporte. No início a implicação entre máxima quantidade e reconhecimento regia as práticas, em seguida, a concessão sobreveio à prática pioneira, progredindo gradualmente na instauração da máxima qualidade (e mínima quantidade) produtora de reconhecimento. Até que ambas as estratégias foram unidas devido ao reconhecimento já adquirido pelos inscritores na atualidade. Detentores de uma volumosa produção, esses artistas com fama estabelecida promoveram uma máxima quantidade da máxima qualidade, agregando estratégias até então separadas ao longo das inscrições urbanas.

\section{Esquema 17 - Relações concessivas e implicativas nas inscrições urbanas}

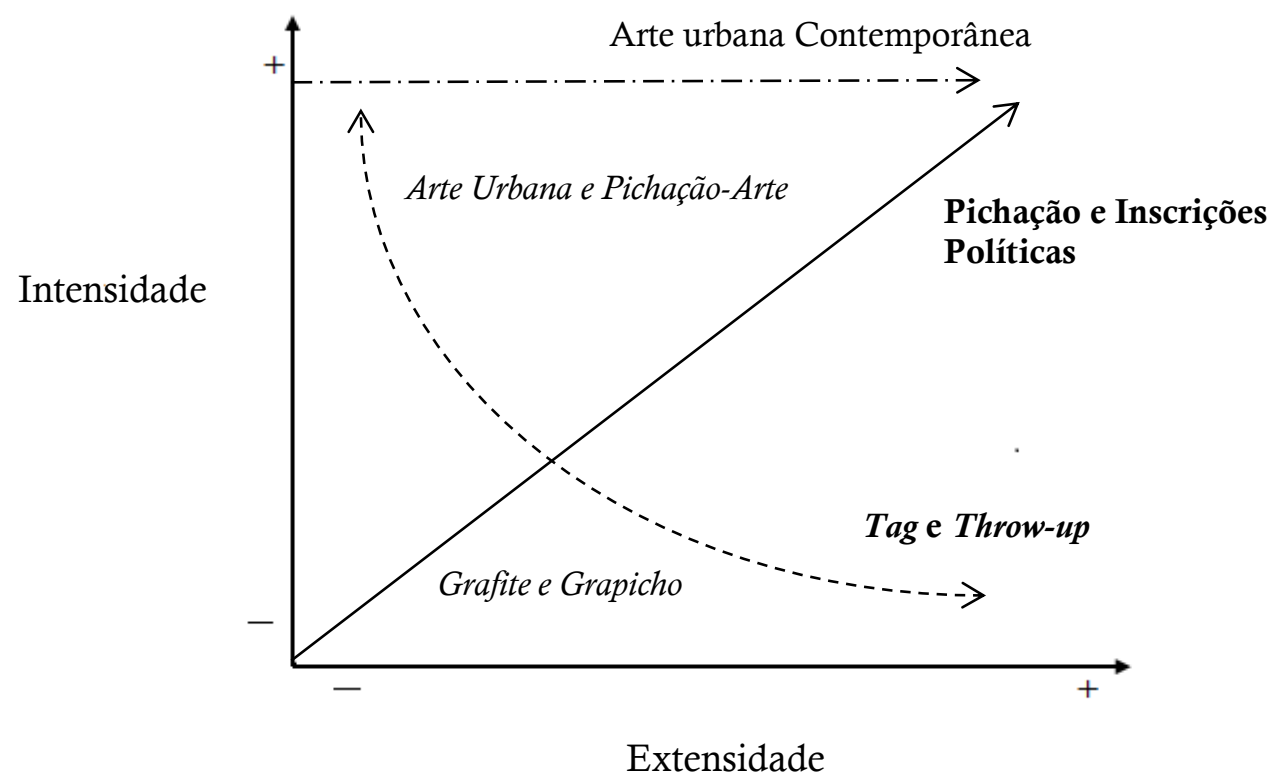

Em termos gerais, os três grupos podem ser colocados no campo tensivo desse modo, mas é válido lembrar que dependendo da época a ser considerada, essa 
disposição muda. O esquema 17 apresenta uma perspectiva atual, ou seja, após a consolidação da história das inscrições urbanas. Isso significa que o grafite e o grapicho já foram estabilizados na cultura, perdendo sua potencialidade do valor reconhecimento, e não teriam tanta intensidade quanto a arte urbana e a pichaçãoarte. Mesmo assim, esse grupo é estruturado por uma lógica concessiva.

Igualmente ao primeiro grupo, a tag e o throw-up possuem hoje em dia pouca relevância, devido à cristalização da prática (chegando à banalização, no caso da tag), enquanto a pichação e sobretudo a inscrição política mantém a alta intensidade. Vale ressaltar que essa configuração é passível de mudança, pois de acordo com a época algumas práticas retomariam seu impacto em favor do valor reconhecimento. Por exemplo, as inscrições políticas, que têm seu aumento na intensidade diretamente ligado à situação política. Na primeira década dos anos 2000 no Brasil, as inscrições políticas não causavam tanto impacto e não eram tão reproduzidas, quanto no ano de 2016. Por causa da situação política brasileira, o número de inscrições políticas aumenta de acordo com a comoção pública.

Da mesma maneira, cada inscrição em sua época retinha uma alta intensidade em sua configuração tensiva, somente com a estabilização da prática e do surgimento de novas práticas, a perda de intensidade foi gradativamente acontecendo. Entretanto essa configuração não é permanente, já que o movimento entre as modalidades é dinâmico e até o momento, as estratégias concessivas e implicativas de cada modalidade foram preservadas, apesar de sua dinamicidade na cultura.

Portanto, as mesmas regras que estruturam o estilo clássico e barroco no nível do texto-enunciado, estruturam as inscrições urbanas no nível da estratégia. Enquanto as pinturas lidavam com uma prática compositiva dentro do mesmo objeto (a tela), as inscrições urbanas debruçavam-se sobre as escolhas de suporte determinadas pela prática. Nesse sentido, estratégias concessivas e implicativas foram elaboradas para o seu melhor desempenho. Os suportes material e formal passam então a ter um papel essencial na compreensão das inscrições urbanas, que não se restringe ao nível do texto, mas integra outros níveis de pertinência em sua estrutura semiótica. 


\section{CONCLUSÃO}

A linguagem é inseparável do homem e segue-o em todos os seus atos.

Hjelmslev 
Conclui-se a abordagem histórica das inscrições urbanas com a ideia de que a prática exige uma investigação em diversos níveis. O percurso histórico foi elaborado eliminando algumas regiões que contribuíram para consolidação das inscrições urbanas. Inglaterra, Alemanha, México e Japão são alguns exemplos de países cuja influência para as inscrições urbanas deve ser mencionada, bem como as inscrições políticas dos países do Oriente Médio e, mesmo que tenham sido lembradas nesta seção do texto, elas acompanharam de modo indireto o desenvolvimento da pesquisa. No entanto a concentração do ponto de vista sobre França, Estados Unidos e Brasil possui sua justificativa e acreditamos que nesses países o movimento possui maior homogeneidade e de certo modo foram eles que preconizaram as principais modalidades de inscrição urbana.

Não se descarta, igualmente, a possibilidade de haver deixado para trás alguma modalidade ou artista pertinente para nossa própria abordagem. A proximidade que as inscrições urbanas possuem no repertório do público é marcante e por isso, as escolhas tornam-se complexas, ainda mais quando aquele artista ou modalidade que é tão caro ao leitor não tenha sido considerado e ainda mais quando escolhas óbvias (para quem lê) não tenham entrado no percurso histórico da prática.

De fato, uma história das inscrições urbanas tratada pela perspectiva da história da arte é ela própria um projeto à parte. Em nenhum momento essa história foi contada de modo definitivo. A história das inscrições urbanas foi construída com a finalidade de analisar a prática em relação à teoria semiótica. As escolhas das modalidades pautaram-se na prática da pintura, ou seja, as modalidades de inscrição urbana que se aproximariam da pintura em sua práxis, guardadas as devidas separações, pois a semiótica visual tem grande afinidade em suas análises com tal objeto e com isso, acreditamos que essa tradição serviria muito bem a nossos objetivos.

Contudo a pintura nas inscrições urbanas exigiu mais que uma análise textual, porque há uma conjunção de fatores para uma pichação ou um grafite chegar ao muro que o percurso de análise demandava a integração de outros níveis de pertinência para explicar esse tipo peculiar de pintura (que não é bem pintura). Além disso, o risco da abordagem está no frescor dessa prática, cuja instabilidade ainda é grande e estabelecer hipóteses sobre ela leva a uma agradável insegurança metodológica. 
Embora os discursos sociais a respeito das inscrições urbanas não tenham sido mostrados detidamente, apontou-se como as inscrições urbanas possuem uma estrutura própria de significação, que o aplauso e a vaia do público são secundários em relação à prática. Dependendo das conjunções e disjunções estabelecidas no interior da modalidade, de determinado uso do suporte e do nível de elaboração da inscrição, os discursos sociais vão posicionar-se. Porém, como toda opinião, o juízo do público muda e o que era rejeitado passa a ser aceito e apreciado no decorrer dos anos.

Evidentemente, as inscrições urbanas não são uma prática autista e as políticas públicas interviram profundamente em seu desenvolvimento, mas o ponto em questão foi demonstrar que há um sistema de produção de sentido interno em cada modalidade, que se comporta como sistema, ou seja, a mudança de um elemento interfere no conjunto e produz sua adequação. Essas mudanças não ocorreram só no nível textual, mas também no da prática.

A presença das inscrições urbanas na sociedade gerou essas adequações no sistema, a prática foi se rearranjando em função de seus valores tanto quanto em função das imposições sociais ou artísticas exteriores às modalidades. A absorção ou a rejeição dessas imposições consolidaram algumas modalidades e produziram inovações, que tiveram uma resposta social positiva ou negativa.

Assim, ao pensar em uma estrutura interna das inscrições urbanas dentro de uma perspectiva diacrônica, o caráter processual sobrepôs-se. Desconsiderando o resumo histórico do primeiro capítulo, os outros três vão apontar o processo de formação em cada nível (prática, texto e objeto) ao longo do tempo. A constituição e o desenvolvimento das modalidades perpassam por toda investigação, pois de acordo com cada nível de pertinência, certas modalidades possuem processos mais complexos que outras e trazer à tona como as inscrições urbanas são constituídas cronologicamente revelam essa estrutura dinâmica.

Diferentemente de outros objetos, as inscrições urbanas exigem um tratamento mais abrangente. Embora uma pintura tradicional possa ser analisada em relação ao tipo de tinta e ao espaço em que ela se encontra, sua práxis cristalizada tenta neutralizar esses elementos exteriores à obra para que a contemplação seja dirigida ao texto plástico, por exemplo, molduras semelhantes, paredes brancas, silêncio do 
ambiente, pintura à altura dos olhos etc. ${ }^{64}$ Já as inscrições urbanas agregam diversos fatores essenciais a sua compreensão. O lugar em que ela se insere, o suporte em que ela foi feita, o grupo social que realizou a inscrição constituem sua significação e ao retirar um desses elementos o enunciado arrefece. Como se uma comutação linguística fosse realizada nessa prática e revelasse que a mudança em um desses três níveis causaria uma mudança de sentido. Colocar uma pintura de Picasso no Museu Reina Sofía ou no MASP não alteraria bruscamente o sentido da obra, mas fazer uma inscrição urbana em Madrid ou em São Paulo pode mudar o significado do texto.

Logo, o desafio da investigação da história das inscrições urbanas foi demonstrar que mesmo com uma maior extensão nos níveis de análise, exigidas pelo objeto, ainda assim foi possível tratar a prática com um método estrutural imanente. $\mathrm{O}$ processo de formação das inscrições urbanas seguia uma coerência sistemática em relação a uma abordagem linguístico-semiótica tão regular que, a todo o momento, a máxima saussuriana (o ponto de vista cria o objeto) se impunha durante a pesquisa.

De forma peculiar, a tese não criou inovações epistêmicas, muito menos fez uma aplicação estrita de uma teoria, mas a partir do objeto, trouxe métodos que dessem conta de explicá-lo. Se tais procedimentos se estendem a outros objetos, não se sabe. Por causa desse foco no objeto, uma mistura teórica foi realizada em favor da teoria semiótica, áreas como linguística, sociologia e história da arte foram incorporadas às análises sem cair na contradição (pelo menos, foi nossa meta).

As exigências de compreensão do objeto levaram à reflexão de métodos e teorias um pouco mais ou um pouco menos próximas da semiótica francesa, que também sofreram um recorte e mesmo dentro dessa semiótica, alguns autores foram privilegiados, o que não significa que outros pontos de vista não dariam conta de analisar o objeto, apenas mostra um ethos da pesquisa.

Devido à abrangência dos níveis de pertinência, a cena enunciativa seria o elemento agregador de todos esses modelos. As escolhas de suporte, as relações normativas e os tipos de inscrição urbana confluem para a enunciação. Mesmo que o tema não tenha sido tratado em uma seção específica, a cena enunciativa está presente em toda a reflexão.

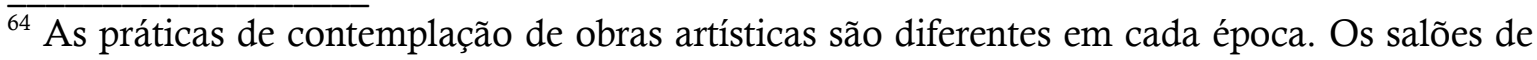
pintura na França, por exemplo, justapunham as obras criando um painel. Nosso exemplo insere-se em uma experiência tradicional a partir do século XX.
} 
Como foi dito, o texto impõe certa competência ao leitor. Embora a escrita didática e clara devesse ser um objetivo científico (ainda mais nas Letras), a tese depende de uma leitura calcada em conhecimentos prévios de semiótica. Em razão dessa postura que faz uma seleção em seu próprio público, há um reforço da imagem dos discursos científicos que falam somente para seus pares. Enquanto o tema da pesquisa produz um efeito de aproximação entre enunciador e enunciatário, seu desenvolvimento talvez requeira certo preparo de leitura que possa afastar o enunciatário.

Enfim, a conclusão feita após a análise das inscrições urbanas é a de que sua significação é construída em diversos níveis de pertinência, mas que ainda assim é possível abordá-los de modo estrutural. Certos textos plásticos dependem de fatores "exteriores" a eles para constituir seu sentido. Porém, se há esse vínculo entre os níveis para a compreensão do texto, o "fora" não estaria "dentro"? Evitar a abordagem dessa interdependência apenas posterga um enfrentamento de objetos que se fazem na conjunção desses níveis.

Além disso, conclui-se também que os discursos sociais referentes às inscrições urbanas são resultantes do próprio sistema interno de cada modalidade. O "bom gosto" é apenas um reflexo da prática. Por exemplo, a pichação é rejeitada socialmente porque sua estrutura rejeita as normas sociais, mas a pichação-arte goza de certo prestígio porque integra as normas artísticas à sua prática, cuja aceitação social é imediata.

Portanto, as inscrições urbanas trazem à teoria semiótica uma reflexão a respeito da transcendência e imanência, já prevista nos prolegômenos de Hjelmslev (2006). E o que a tese mostra é menos o debate sobre esse assunto que uma tentativa prática de integrar as duas abordagens. Acreditamos que os métodos de análise utilizados podem e devem ser questionados, porém, a necessidade de uma análise transversal capaz de lidar com essa interdependência, essencial à produção de sentido, tenha se efetivado pela investigação das inscrições urbanas. A ciência sobre o sentido deve manter suas premissas teóricas, sem que estas se sobreponham em detrimento das estruturas de seu próprio objeto: o sentido. 


\section{REFERÊNCIAS}

7 GRAUS. Paz. Dicionário de Símbolos: Significado dos símbolos e Simbologias, 2008. Disponivel em: <http://www.dicionariodesimbolos.com.br/paz/>. Acesso em: 27 mar. 2016.

ALBERTI, L. B. Da Pintura. Campinas: Editora Unicamp, 1999.

ALMEIDA, F. Mercado de arte contemporânea: construção do valor artístico e do estatuto de mercado do artista. Forum Sociológico [Online], 2009. Disponivel em: <http://sociologico.revues.org/203>. Acesso em: 11 nov. 2015.

APRENDER LÍNGUAS. Aprender Dinamarquês. Aprender Línguas, 2016. Disponivel em: <http://www.aprender-dinamarques.com/artigo-definidodinamarques.html>. Acesso em: 21 fev. 2016.

ARGAN, G. C. Arte moderna: do iluminismo aos movimentos contemporâneos. São Paulo: Cia das Letras, 2010.

ARTRIBUNE. Lorenzo Lotto - Susanna e i vecchioni - olio su tavola - 1517 Firenze, Galleria degli Uffizi. Artribune, 2012. Disponivel em: $<$ http://www.artribune.com/2012/03/tutti-i-verdi-del-cinquecento/5-232/>. Acesso em: 21 out. 2015.

ASPECTO URBANO. Sección Piezas. Aspecto Urbano, 2008. Disponivel em: $<$ http://aspectourbano.blogspot.com.br/2008/06/seccin-piezas.html>. Acesso em: 10 jun. 2016.

ASSIS, T. D. Um tour pelo centro de SP com o pichador Djan Cripta. O beijo, 2016. Disponivel em: <http://www.obeijo.com.br/noticias/um-tour-pelo-centro-de-sp-como-pichador-djan-cripta-12771454> . Acesso em: 20 maio 2016.

BAGNO, M. Norma Linguística. São Paulo: Edições Loyola, 2011.

BANDO CENTRAL. Paris. Bando Central, 2016. Disponivel em: <https://www.graffiti.org/bando/ban105.jpg>. Acesso em: 10 jun. 2016.

BANKSY. Guerra e Spray. Rio de Janeiro: Intrínseca, 2012.

BANKSY. Outside. Banksy, 2014. Disponivel em: <http://banksy.co.uk/out.asp>. Acesso em: 20 maio 2014.

BARROS, D. L. P. D. Teoria do discurso: fundamentos semióticos. São Paulo: Humanitas, 2002. 
BELLIS, M. About.com. About.com, New York, 14 agosto 2012. Disponivel em: $<$ http://inventors.about.com/od/astartinventions /a/aerosol.htm>. Acesso em: 14 agosto 2014.

BENVENISTE, É. Problemas de Linguística Geral. São Paulo: Conpanhia editora nacional / editora Universidade de São Paulo, v. 1, 1976.

BENVENISTE, É. Problemas de linguística geral. São Paulo: Pontes, v. 2, 1989.

BESANÇON, J. Les murs ont la parole. Paris: Editions Tchou, 2007.

BESIDE COLORS. Lendas da Pixação - \#DI\#. Beside Colors, 2011. Disponivel em: <http://besidecolors.com/lendas-da-pixacao-di/>. Acesso em: 10 jun. 2016.

BESIDE COLORS. Lixomania. Beside Colors, 2011. Disponivel em: <http://besidecolors.com/tag/lixomania/>. Acesso em: 10 jun. 2016.

BESIDE COLORS. Naldo. Beside colors, 2011. Disponivel em: $<$ http://besidecolors.com/tag/naldo/>. Acesso em: 10 jun. 2016.

BESIDE COLORS. A pré- história da Pixação. Beside colors, 2015. Disponivel em: <http://besidecolors.com/a-pre-historia-da-pichacao/>. Acesso em: 10 jun. 2016.

BÍBLIA. Matheus, 13: 24-30. Bíblia online. Disponivel em: <https://www.bibliaonline.com.br/>. Acesso em: 16 jul. 2014.

BIENAL DE SÃO PAULO. Alex vallauri, ao alcance de todos. Bienal, 2013. Disponivel em: <http://www.bienal.org.br/post.php?i=335>. Acesso em: 10 jun. 2016.

BLEK LE RAT. First rats in Paris 1981. Blek le Rat, 2016. Disponivel em: <http://bleklerat.free.fr/1a/stencil\%20graffiti\%201.html>. Acesso em: 10 jun. 2016.

BORBA, F. D. S. Dicionário UNESP do Português contemporâneo. São Paulo: Unesp, 2004.

BORDRON, J.-F. Trois ordres de la valeur selon la qualité, la quantité et la relation, Besançon, 01 out. 2011. 16.

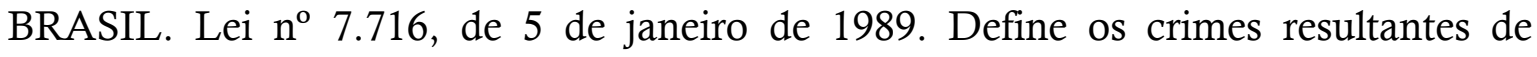
preconceito de raça ou de cor. Art. 20. Disponível em: < http://www.planalto.gov.br/ ccivil_03/leis/L7716.htm>. Acesso em: 10 mai. 2016.

BUENO, L. E. B. Linguagem das artes visuais. Curitiba: InterSaberes, 2013.

CAMPOS, A. D. Poemas - Lygia fingers. Agusto de Campos - Página oficial, 1999. Disponivel em: <http://www2.uol.com.br/augustodecampos/01_01.htm>. Acesso em: 02 mar. 2016. 
CAMPOS, A. D. Viva Vaia. São Paulo: Ateliê, 2014.

CASTLEMAN, C. Getting up/Hacerse ver: el grafiti metropolitano en Nueva York. Salamanca: Capitán Swing, 2012.

CHALFANT, H.; COOPER, M. Subway art. Nova Iorque: Thames \& Hudson, 2015.

CHALFANT, H.; JENKINS, S. Training Days: the subways artists then and now. Londres: Thames \& Hudson, 2014.

CHALFANT, H.; PRIGOFF, J. Spraycan Art. Londres: Thames and Hudson, 2009.

CHARLES, D. H. "Taki 183" Spawns pen pals. The New York Times, New York, julho 1971. Disponivel em: <http://taki183.net/_pdf/taki_183_nytimes.pdf>. Acesso em: 14 agosto 2014.

CIDADE CINZA. Direção: Marcelo MESQUITA e Guilherme. VALIENGO. Produção: Pepe Siffredi, Raphael Bottino e Guilherme Valiengo Marcelo Mesquita. [S.1.]: Sala 12 Filmes e Motion. 2013. Documentário.

CLARKE, R. Seven years with Banksy. Londres: Michael O' Mara, 2012.

CORREA, T. M. Sem título. São Paulo: [s.n.], 2016. Fotos de arquivo pessoal.

COSERIU, E. Teoria da linguagem e linguística geral: cinco estudos. Rio de Janeiro: Ed. Presença, 1979.

COSTA, R. R. A. Graffiti no contexto histórico-social, como obra aberta e uma manifestação de comunicação urbana. São Paulo: Universidade de São Paulo / ECA, 1994. Dissertação de Mestrado.

CRASH. Works. John Crash Matos, 2014. Disponivel em: <http://www.crashone.com/\#!trains/jlxpz>. Acesso em: 18 out. 2015.

CRIPTA. Homepage. Cripta Djan, 2013. Disponivel em: <http://www.criptadjan.com/>. Acesso em: 11 jul. 2015.

DARCO. SNCF: oui à la fresque! All city blog, 2010. Disponivel em: <http://www.allcityblog.fr/13071-sncf-oui-a-la-fresque/>. Acesso em: 10 jun. 2016.

DOCKHORN, N. Estruturas morfossintáticas de outras línguas muito divergentes. CADERNOS DO CNLF, Rio de Janeiro, Vol. 11, n. 12, 2008. Disponivel em: $<$ http://www.filologia.org.br/xicnlf/12/estruturas_morfossint\%C3\%A1ticas_de_outr as_linguas.pdf $>$. Acesso em: 21 fev. 2016.

DONDERO, M. G. Le Soliloque en photographie. Centre de Recherche sur l'Image (CRI), 2006. Disponivel em: <http://cri-image.univ-paris1.fr/accueil.html>. Acesso em: 29 nov. 2015. 
DONDERO, M. G. Rhétorique et énonciation visuelle. Visible: rhétorique et visualisation scientifique, Limoges, n. 10, 2013. 9-31.

DONDERO, M. G. Les aventures du corps et de l'identité dans la photographie de mode. Actes Sémiotiques, Paris, p. 24, 2014. Disponivel em: <http://epublications.unilim.fr/revues/as/4979>. Acesso em: 20 fev. 2015.

DONDERO, M. G. O problema da substância do plano da expressão: acerca das imagens científicas e artísticas. Grupo de estudos semióticos da Universidade de São Paulo, São Paulo, 2016. Disponivel em: <http://semiotica.fflch.usp.br/node/446>. Acesso em: 01 jun. 2016. Gravação em audio.

DONDERO, M. G.; REYES, E. Les supports des images : photographie et images numériques, Pessac, 2016. Disponivel em: <https://rfsic.revues.org/>. No prelo.

ELIAS, E. D. O. Escritura urbana: invasão da forma, evasão do sentido. São Paulo: Perspectiva, 1989.

ELLSWORTH-JONES, W. Banksy: por trás das paredes. Curitiba: Nossa Cultura, 2013.

EMMERLING, L. Jean-Michel Basquiat: a força explosiva das ruas. Lisboa: Taschen, 2003.

EXIT THROUGH THE GIFT SHOP. Direção: Banksy. Produção: Jaimie D'Cruz,James Gay-Rees Holly Cushing. Intérpretes: Banksy. [S.1.]: Paranoid Pictures. 2010.

FAIREY, S. Prints. Obey Giant, 1995. Disponivel em: <https://obeygiant.com/prints/>. Acesso em: 10 jun. 2016.

FATCAP. Street Art By Seikon - Gdynia (Poland). Fatcap, 2011. Disponivel em: <http://www.fatcap.com/graffiti/165111-seikon-gdynia.html>. Acesso em: 10 jun. 2016.

FIORIN, J. L. O projeto hjelmsleviano e a semiótica francesa. Galáxia, São Paulo, 2003. Disponivel em: <http://revistas.pucsp.br/index.php/galaxia/ article/view/1314/810>. Acesso em: 02212016.

FIORIN, J. L. Em busca do sentido: estudos discursivos. São Paulo: Contexto, 2008.

FIORIN, J. L. Polifonia textual e discursiva. In: BARROS, D. L. P. D.; FIORIN, J. L. Dialogismo, Polifonia e Intertextualidade em Torno de Bakhtin. São Paulo: Edusp, 2011. p. 30-36.

FLOCH, J. Petites mythologies de l'œil et de l'esprit. Pour une sémiotique plastique. Paris-Amsterdam: Hadès-Benjamins, 2014. E-book. 
FLOCH, J.-M. Indentités Visuelles. Paris: PUF, 1995.

FLORES, V. N. Dicionário de Linguística da Enunciação. São Paulo: Contexto, 2009.

FONTANILLE, J. Les espaces subjectifs: Introduction à la sémiotique de l'observateur (discours, peinture, cinéma). Paris: Hachette, 1989.

FONTANILLE, J. Du support matériel au support formel. In: KLOCKFONTANILLE, A. \&. L'Ecriture entre support et surface. Paris: L'Harmattan, 2005. p. 183-200. Disponivel em: <http://www.unilim.fr/pages_perso/ jacques.fontanille/articles_pdf/>. Acesso em: 02 maio 2016.

FONTANILLE, J. Práticas semióticas: imanência e pertinência, eficiência e otimização. In: DINIZ, M. L. V. P.; PORTELA, J. C. Semiótica e mídia: textos,práticas, estratégias. Bauru: UNESP/FAAC, 2008.

FONTANILLE, J. Formes de vie. Liège: Presses universitaires de Liège, 2015.

FONTANILLE, J. Pratiques Sémiotiques. Paris: PUF, 2015.

FONTANILLE, J.; ZILBERBERG, C. Tensão e significação. São Paulo: Humanitas, 2001.

FOSSALI, P. B.; DONDERO, M. G. Sémiotique de la photographie. Limoges: Pulim, 2011.

GANZ, N. O mundo do grafite: arte urbana dos cinco continentes. São Paulo: Martins Fontes, 2008.

GENIN, C. Images et esthétique. Paris: Publications de la Sorbonne, 2007.

GÉNIN, C. Miss.tic, femme de l'être. Bruxelles: [s.n.], 2008.

GENIN, C. Le street art au tournant: reconnaissances d'un genre. Bruxelas: Les impressions nouvelles, 2013.

GOMBRICH, E. H. A história da arte. Rio der Janeiro: LTC, 2009.

GREFFE, X. Arte e Mercado. São Paulo: Iluminuras/Itaú Cultural, 2013.

GREIMAS, A. J. Semiótica e ciências sociais. São Paulo: Cultrix, 1982.

GREIMAS, A. J. Semiótica plástica e Semiótica figurativa. Significação, Araraquara, n. 4, 1984. Trad. de I. A. Silva.

GREIMAS, A. J. Da imperfeição. São Paulo: Hacker, 2002.

GREIMAS, A. J. Sobre o sentido II: ensaios semióticos. São Paulo: Edusp, 2015. 
GREIMAS, A. J.; COURTÉS, J. Dicionário de Semiótica. São Paulo: Contexto, 2008.

GREIMAS., A. J. Du sens: essais semiotiques. Paris: Ed du Seuil, 1983.

HAINS, R.; VILLEGLÉ, J. ACH ALMA MANETRO: L'oeuvre. Centre Pompidou, 2016. Disponivel em: <https://www.centrepompidou.fr/cpv/resource/ caj5E7e/r6bKGrb>. Acesso em: 10 maio 2016.

HARKOT-DE- LA-TAILLE, E. Sentir, saber, tornar-se: estudo semiótico do percurso entre o. São Paulo: FFLCH, 2013. Tese de Livre-Docência.

HJELMSLEV, L. Prolegómenos a una teoría del lenguaje. Madrid: Gredos, 1969.

HJELMSLEV, L. Prolegômenos a uma teoria da linguagem. São Paulo: Perspectiva, 2006.

HUNTER, G. Arte de rua ao redor do mundo. São Paulo: Madras, 2013.

INSTITUTO ANTÔNIO HOUAISS. Uol. Grande dionário Houaiss da Língua Portuguesa Beta, 2012. Disponivel em: <http://houaiss.uol.com.br/>. Acesso em: 18 mar. 2016.

INVADER. World Invasion. Space Invader, 2014. Disponivel em: <http://spaceinvaders.com/world/>. Acesso em: 14 fev. 2016.

INVENTIN. Graffiti de mai 68 / Les inventeurs d'incroyances - insoumis. Inventin, 2016. Disponivel em: <http://inventin.lautre.net/graffiti.html>. Acesso em: 10 jun. 2016.

JAKOBSON, R. Linguística e Comunicação. São Paulo: Pensamento, 2005.

JANSON, H. W. História da arte. Lisboa: Fundação Calouste Gulbenkian, 2005.

KANDINSKY, W. Ponto e linha sobre plano. São Paulo: Martins Fontes, 2005.

KHUTAREV, V. A foice e o martelo: o místico emblema do país dos sovietes. Gazeta Russa, 20 jul. 2014. Disponivel em: <http://gazetarussa.com.br/arte/ 2014/07/20/a_foice_e_o_martelo_o_mistico_emblema_do_pais_dos_sovietes_26525 >. Acesso em: 20 mar. 2016.

KLINKENBERG, J.-M. Normes linguistiques, normes sociales, endogenèse. In: BAVOUX, C.; PRUDENT, L. . F.; WHARTON, S. Normes endogènes et plurilinguisme. Aires francophones, aires créolophones. Lyon: ENS Editions, 2008. p. 17-32.

KLINKENBERG, J.-M. La Mutation des Normes Sociales et Langagières: Conditions de Production des Littératures Périphériques. In: KASSAB-CHARFI, S. 
Altérité et Mutations dans la Langue: Pour Une Stylistique des Littératures Francophones. Bruxelas: Academia-Bruylant, v. Coleção Au Cœur des Textes, 19, 2010. p. 17-28.

KLINKENBERG, J.-M.; BENOÎT, D. La littérature belge. Précis d'histoire sociale. Bruxelles: Labor, 2005.

KRTOLICA, I. Image/langage chez Deleuze. Departement de Philosophie ULg, 13 novembro 2015. Disponivel em: <http://web.philo.ulg.ac.be/philosophie/premierquadrimestre/>. Acesso em: 29 jan. 2016.

LASSALA, G. Pichação não é pixação. São Paulo: Altamira, 2010.

LEIBOVITZ, A. Keith Haring, New York, 1986. Paddle 8, 2016. Disponivel em: $<$ https://paddle8.com/work/annie-leibovitz/29439-keith-haring-new-york>. Acesso em: 10 jun. 2016.

LEMOS, C. L. Condições semióticas da repetição. 232 f. 2015. Tese (Doutorado) Faculdade de Filosofia, Letras e Ciências Humanas, Universidade de São Paulo, São Paulo, 2015.

LEONZINI, N. Keith Haring. São Paulo: Centro Cultural Banco do Brasil, 2003. Catálogo de exposição artística sobre Keith Haring.

LIMA, J. P. A teoria glossemática de louis hjelmslev numa perspectiva historiográfico-linguística. Goiânia: Universidade Federal de Goiás, 2010.

LOPES, E. A identidade e a diferença. São Paulo: Edusp, 1997.

LOPES, M. Semântica extensiva. In: CORTINA, A.; MARCHEZAN, R. C.; (ORG.) Razões e sensibilidades: a semiótica em foco. Araraquara: Cultura acadêmica editora, 2004. p. 36-49.

LÓPEZ, A. J. El arte de la calle. Reis: Revista española de investigaciones sociológicas, Madrid, outubro 1998. p. 173-194. Disponivel em: $<$ http://dialnet.unirioja.es/ servlet/ejemplar?codigo=82280 $>$. Acesso em: 14 agosto 2014.

LUPTON, E. Pensar com tipos: guia para designers, escritores, editores e estudantes. São Paulo: Cosac Naify, 2013.

LUTHER KING JR., M. National Archives. The U.S. National Archives and Records Administration, 1963. Disponivel em: <http://www.archives.gov/press/exhibits/dream-speech.pdf $>$. Acesso em: 17 jul. 2014.

MAIAN, J. Sem título. São Paulo: [s.n.], 2015. Fotos de Arquivo Pessoal. 
MANCO, T.; ART, L.; NEELON, C. Graffiti Brasil. Londres: Thames \& Hudson, 2005.

MANESSY, G. Norme endogène et normes pédagogiques en Afrique noire francophone. In: BAGGIONI, D. Multilinguisme et développement dans l'espace francophone. Paris: Didier érudition, 1992. p. 43-81.

MCCONNELL, J. Art: Farewell Tacheles. M.A.V.B.L.O.G., 2013. Disponivel em: <http://www.josephmcconnell.com/archives/653>. Acesso em: 10 jun. 2016.

MERTON, R. K. Sociologia: teoria e estrutura. São Paulo: Mestre Jou, 1970.

MISS.TIC. Le hasard bave des formules de magie noire (1985). Miss-Tic 1985-2014, 2014. Disponivel em: <http://missticinparis.com/archives/pochoirs-des-rues/19852/>. Acesso em: 12 fev. 2014.

MORAES, A. Expansão de valor. In: QUEMIN, A. O valor da obra de arte. São Paulo: Metalivros, 2014. p. 206-238. Entrevista com Luisa Strina.

MUELLER, E. Mysterious Caves in Europe. Edgar Mueller, 2011. Disponivel em: $<$ http://www.metanamorph.com/index.php?site=project\&cat_dir=The-

Caves\&proj=Mysterious-Caves-in-Europe> . Acesso em: 10 jun. 2016.

MUSÉE HISTORIQUE ENVIRONNEMENT URBAIN. Suzanne et les deux vieillards. Musée Historique environnement urbain, 2009. Disponivel em: <http://www.mheu.org/fr/chronologie/suzanne-deux-vieillards.htm>. Acesso em: 15 jul. 2015.

NETO, B. P. G. Graffiti: do subversivo ao sagrado. São Paulo: Universidade de São Paulo, 2011.

NINA PANDOLFO. Projetos. Nina Pandolfo, 2016. Disponivel em: <http://www.ninapandolfo.com.br/>. Acesso em: 10 jun. 2016.

NYC-ARTS. Banksy NY: Better Out Than In. NYC - Arts: the complete guide, 2015. Disponivel em: <https://www.nyc-arts.org/collections/80384/banksy-better-outthan-in>. Acesso em: 20 maio 2016.

OLIVEIRA, Taís. Enunciação e intertextualidade no filme As horas, de Stephen Daldry. 2015. 118 f. Dissertação (Mestrado) - Faculdade de Filosofia, Letras e Ciências Humanas, Universidade de São Paulo, São Paulo, 2016.

OSGEMEOS. Ópera da lua. Rio de Janeiro: Cobogó, 2014. Catálogo de exposição.

OUSHIRO, L. Identidade na Pluralidade: avaliação, produção e percepção linguística na cidade de São Paulo. 2015. 394 f. Tese (Doutorado) - Faculdade de Filosofia, Letras e Ciências Humanas. Universidade de São Paulo, São Paulo, 2015. 
OXFORD. The Oxford English Dictionary. Oxford Dictionaries: Language matters, Oxford, 2014. Disponivel em: <http://www.oxforddictionaries.com/words/theoxford-english-dictionary>. Acesso em: 14 ago. 2014.

PARIS, P. D. Le Pressionisme 1970-1990: les chefs d'oeuvre du graffiti sur toile de Basquiat à Bando. Paris : Pinacothèque de Paris, 2015.

PARRILLA, A. M. Remembering Jean-Michel Basquiat. Voilà- Madame!, 2016. Disponivel em: <http://www.voila-madame.com/2010/09/remembering-jeanmichel-basquiat.html>. Acesso em: 10 jun. 2016.

PIETROFORTE, A. V. Semiótica Visual: os Percursos do Olhar. São Paulo: Contexto, 2003.

PIETROFORTE, A. V. $O$ discurso da poesia concreta. São Paulo: Fapesp/Annablume, 2011.

PIGNON-ERNEST, E. Interventions: L'origine. Ernest Pignon-Ernest, 2015. Disponivel em: <http://pignon-ernest.com/>. Acesso em: 10 jun. 2016.

PINACOTHÈQUE DE PARIS. Le Pressionnisme 1970-1990: les chefs d'oeuvre du graffiti sur toile de Basquiat à Bando. Paris: Pinacothèque de Paris, 2015.

PIXO. Direção: Roberto T. Oliveira João Wainer. Produção: Roberto T. Oliveira. [S.1.]: [s.n.]. 2009.

PONDIAN, J. D. F. Relações entre expressão e conteúdo. Estudos Semióticos, São Paulo, 2005.

PONOSOV, I. Street Art as the Art of Action. Partizaning: Participatory urban replanning., 2013. Disponivel em: <http://eng.partizaning.org/?p=4938>. Acesso em: 10 jun. 2016.

PRADO, M. G. S. Jacques Fontanille, Práticas semióticas: imanência e pertinência, eficiência e otimização. Estudos Semióticos, São Paulo, 6, n. 1, junho 2010. Disponivel em: <http://www.fflch.usp.br/dl/semiotica/es/eSSe61/2010esse61mgsprado.pdf $>$.

PROENÇA, R. Visões do térreo. São Paulo: Editora 34, 2007.

QUOTES LINKS. Quotes Links. Gandhi an eye for an eye, 2016. Disponivel em: <http://lh5.ggpht.com/_DW_dyBBaOTQ/TBVMBeIZ12I/AAAAAAAAGMI/U7I biLlw-1M/s1600/jef-aerosol-gandhi.jpg>. Acesso em: 10 jun. 2016.

RAE. Diccionario panhispánico de dudas. Real Academia Española, 2005. Disponivel em: <http://buscon.rae.es/dpd/srv/search?id=d45ahCOicD6TkHkns8>. Acesso em: $21 \mathrm{fev} .2016$. 
REISNER, R. Graffiti: two thousand years of wall writing. Chicago: Cowles Book, 1971.

RESISTENCIA ARQUIVO. Pelos muros da ditadura, Ações de resistência. Resistencia Arquivo, 2014. Disponivel em: $<$ https://resistenciaemarquivo.wordpress.com/2014/04/17/_ pelos-muros-daditadura-acoes-de-resistencia-a-ditadura/>. Acesso em: 10 jun. 2016.

RICOEUR, P. Parcours de la reconnaissance Trois études. Paris: Gallimard, 2005.

ROTA-ROSSI, B. Alex Vallauri: da gravura ao grafite. São Paulo: Ohares, 2013.

SANDLER, R. Richard Sandler photography. Richard Sandler, 2016. Disponivel em: <http://www.richardsandler.com/photography.html>. Acesso em: 10 jun. 2016.

SANZA. BD et fresques murales. Disponivel em: <http://bdmurales.skynetblogs.be/>. Acesso em: 28 jan. 2016.

SÃO PAULO. Lei $n^{\circ}$ 14.223, de 26 deSetembro de 2006. Lei Cidade Limpa. Disponível em: <http://www.mpsp.mp.br/portal/page/portal/Cartilhas/ Lei\%20Cidade\%20Limpa.pdf>. Acesso em: 23 out. 2015.

SAUSSURE, Ferdinand de. Cours de linguistique générale. Paris: Payot, 1997.

SCHWARTZMANN, Saulo Nogueira. Semiótica da composição pictural: o jogo tensivo entre o figurativo e o plástico na Série das ligas de Wesley Duke Lee. 2014. 151 f. Dissertação (Mestrado) - Faculdade de Filosofia, Letras e Ciências Humanas da Universidade de São Paulo, 2014.

SEAN. Switzerland: The Sprayer of Zürich: Harald Naegeli. Pictures and perspectives, 2009. Disponivel em: <http://picturesandperspectives.blogspot.com.br /2009/03/sprayer-of-zurich-harald-naegeli.html>. Acesso em: 10 jun. 2016.

SENO, E. Trespass: história da arte urbana não encomendada. Colônia: Taschen, 2010.

SEO, J. Material container. Jeonghwa Seo, 2013. Disponivel em: <http://jeonghwaseo.com/index.php/works/material-container/2/>. Acesso em: 10 abr. 2016.

SHAÏRI, H.-R.; FONTANILLE, J. Approche sémiotique du regard photographique: deux empreintes de l'Iran contemporain. Université de Limoges, p. 27, 2001. Disponivel em: <http://www.unilim.fr/pages_perso/jacques.fontanille/articles_pdf/visuel/semiotiq ueregarddanslesphotosorientales.pdf $>$. Acesso em: 31 fev. 2016. 
SHARF, K. FRED \& WILMA IN HEAVEN. Kenny Sharf, 2016. Disponivel em: <http://kennyscharf.com/paintings/1980-2/>. Acesso em: 10 jun. 2016.

SILVA, T. C. Dicionário de Fonética e Fonologia. São Paulo: Contexto, 2011.

SKURKTUR. CMYK. Skurktur, 2009. Disponivel em: <http://skurktur.com/ gallery/cmyk>. Acesso em: 27 fev. 2016.

SLEEPBOY. Streets: Nunca (Los Angeles). Arrested Motion, 2013. Disponivel em: $<$ http://arrestedmotion.com/2013/08/streets-nunca-los-angeles/>. Acesso em: 10 jun. 2016.

STAHL, J. Street Art. Potsdam: h.f. ullman, 2009.

STOICHITA, V. L'instauration du tableau. Métapeinture à l'aube des Temps modernes. Paris: Méridiens Klincksieck, 1993.

STYLE WARS. Direção: Tony SILVER. Produção: Tony SILVER e Henry CHALFANT. [S.1.]: [s.n.]. 1984.

SUBSOLO ART. Graffiti: Download do filme de Jean-Michel Basquiat. Subsolo Art, 2012. Disponivel em: <http://subsoloart.com/blog/2012/03/download-do-filme-doartista-jean-michel-basquiat/> . Acesso em: 10 fev. 2016.

SUBWAY OUTLAWS. Hand Style 6. Subway Outlaws, 2016. Disponivel em: $<$ http://www.subwayoutlaws.com/tag\%20page2/tag_6.htm>. Acesso em: 10 jun. 2016.

SUBWAY OUTLAWS. Throw Ups. Subway Outlaws, 2016. Disponivel em: <http://www.subwayoutlaws.com/throwies/Throwies.htm>. Acesso em: 10 jun. 2016.

SUPERRADNOW. Rammellzee. SuperRadNow, 2011. Disponivel em: <https://superradnow.wordpress.com/tag/rammellzee/>. Acesso em: 10 jun. 2016.

TALMY, L. Toward a Cognitive Semantics. Boston: MIT Press, v. 1, 2000.

THE ALL TIME KINGS OF NEW YORK GRAFFITI. The top ten nyc graffit bombers of all time. The all time Kings of New York Graffiti, 2012. Disponivel em: <https://kingsofgraffiti.wordpress.com/>. Acesso em: 10 jun. 2016.

THE CRYPT. The Olympic Graffiti Legacy. The Crypt, 2002. Disponivel em: $<$ https://holmesfromthecrypt.wordpress.com/2012/09/02/the-olympic-graffitilegacy/\#content-wrapper>. Acesso em: 22 jan. 2016.

THE KEITH HARING FOUNDATION. Pop Shop. The Keith Haring Foundation, 1997. Disponivel em: <http://www.haring.com/!/pop-shop>. Acesso em: 10 jun. 2016. 
THÜRLEMAN, F. Trois pentures de Paul Klee: essai d'aanalyse sémiotique. Paris: [s.n.], 1979.

THÜRLEMANN, F. Blumen-Mythos (1918) de P. Klee. Ateliers de sémiotique visuelle. ed. Paris: P.U.F, 2004.

TSCHICHOLD, I. Tipografia elementar. São Paulo: Altamira, 2007.

VALÉRY, P. Variedades. São Paulo: Iluminuras, 1999.

VELOSO, C. Proibido Proibir. São Paulo: Philips, 1968.

VIEL, R. Grafite: o que dizem os muros de Lisboa. Continente, Pernambuco, n. 176, p. 51-54, ago 2015.

WILD STYLE. Direção: Charlie Ahearn. Produção: Charlie Ahearn. [S.1.]: Wild Style. 1983.

WÖLFFLIN, H. Conceitos fundamentais da história da arte. São Paulo: Martins Fontes, 2006.

ZEZÃO. Córregos. Zezão, 2012. Disponivel em: <http://www.zezaoarts.com.br/ corregos.php>. Acesso em: 10 jun. 2016.

ZHAO, M. Pixacao in NYC Gallery with Cripta Djan. Minling Zhao Photography, 2016. Disponivel em: <http://photography.minlingzhao.com/pixadores-gallery-withcripta-djan/>. Acesso em: 26 maio 2016.

ZILBERBERG, C. As condições semióticas da mestiçagem. In: CAÑIZAL, E. P.; CAETANO, K. E. O olhar à deriva: mídia, significação e cultura. São Paulo: Annablume, 2004. p. 69-102.

ZILBERBERG, C. Louvando o acontecimento, São Paulo, p. 13-28, jun. 2007a. Disponivel em: <http://revistas.pucsp.br/index.php/galaxia/article/view/1472/938>. Acesso em: 03 maio 2015.

ZILBERBERG, C. De la Consistence, 2007b. Disponivel em: $<$ http://www.claudezilberberg.net/pdfs/De\%201a\%20consistance.pdf>. Acesso em: 22 jan. 2016.

ZILBERBERG, C. De l'événement, 2008. Disponivel em: $<$ http://www.claudezilberberg.net/pdfs/Delevenemet.pdf $>$. Acesso em: 20 mar. 2016.

ZILBERBERG, C. Observações sobre a base tensiva do ritmo. Estudos Semióticos, São Paulo, 6, 2010. 
ZILBERBERG, C. Des formes de vie aux valeurs. Paris: PUF, 2011a.

ZILBERBERG, C. Elementos de semiótica tensiva. São Paulo: Ateliê, 2011 b.

ZILBERBERG, C. La structure tensive suivi de Note sur la structure des paradigmes et de Sur la dualité de la poétique. Liège: Presses Universitaires de Liège, 2012.

ZLOTYKAMIEN, G. STREET ART : LA RECONNAISSANCE ARTISTIQUE. ô Magazine, 2015. Disponivel em: <http://omagazine.fr/street-art-la-reconnaissanceartistique/>. Acesso em: 10 jun. 2016. 